\title{
AVALIAÇÃO DO IMPACTO DA PROLIFERAÇÃO DE ODORES OFENSIVOS DO TRATAMENTO DE ESGOTOS SOBRE A SAÚDE E O BEM ESTAR PÚBLICOS: \\ ETE - PIRACICAMIRIM - PIRACICABA - SP
}

ROSANA CRISTINA DE SOUZA GIULIANO

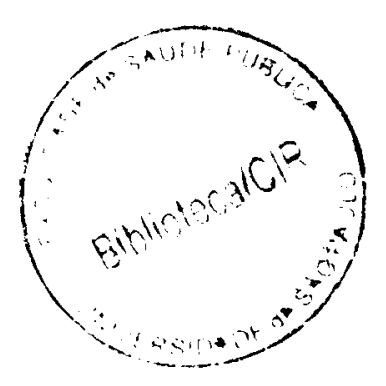

São Paulo

2002 


\section{AVALIAÇÃO DO IMPACTO DA PROLIFERAÇÃO DE ODORES OFENSIVOS DO TRATAMENTO DE ESGOTOS SOBRE A SAÚDE E O BEM ESTAR PÚBLICOS: \\ ETE - PIRACICAMIRIM - PIRACICABA - SP}

ROSANA CRISTINA DE SOUZA GIULIANO

Tese de Doutorado apresentada ao Departamento de Saúde Ambiental da Faculdade de Saúde Pública da Universidade de São Paulo para obtenção do Grau de Doutor.

Área de concentração: Saúde Ambiental

ORIENTADOR: PROF. DR. ROQUE PASSOS PIVELI

São Paulo

2002 
Autorizo, exclusivamente para fins acadêmicos e cientificos, a reprodução total ou parcial desta tese, por processos fotocopiadores, desde que citada a fonte.

Assinatura:

Data:

$$
4298512002 \text { dr }
$$


“Agrada-te do Senhor, e ele satisfará aos desejos do teu coração.

Entrega o teu caminho ao Senhor, confia nefe, e o mais efe fará".

Salmo 37:4-5 
Para Donny e Beto, com todo o meu amor. 


\section{AGRADECIMENTOS}

Os mais sinceros agradecimentos:

Ao Prof. Dr. Roque Passos Piveli, pela orientação prestada.

Ao Prof. Dr. Nemésio N. B. Salvador (DECiv-UFSCar), mestre e conselheiro.

Ao Prof. Dr. Bruno Coraucci Fitho (FEC-UNICAMP), peto incentivo e colaboração sempre oportunas.

À Profa. Dra. Norma F. L. S. Valêncio (Depto. Ciências Sociais UFSCart, peto respaldo nos conceitos e técnicas relativos à pesquisa sociat.

Ao Prof. Dr. João Vicente de Assunção (HSA-FSP) e ao Prof. Dr. Arnatdo Alves Cardoso (Depto. Química Analítica - UNESP - Araraquara) pelos artigos e sugestões apresentadas.

À Profa. Dra. Wanda M. R. Gunther (HSA-FSP), ao Prof. Dr. Edson A. Abdut Nour (FEC-UNICAMP) e ao Prof. Dr. Aristides Almeida Rocha (HSAFSP) pelas contribuições na etapa de pré-banca.

À CAPES (Coordenação de Aperfeiçoamento de Pessoal de Nivel Superior) pela bolsa de estudo concedida.

Ao SEMAE (Serviço Municipal de Água e Esgoto de Piracicaba) pelas informações prestadas e pelo material de apoio (mapas).

Ao Eng. Gilson L. Merti pelo apoio técnico.

Ao Junior pela digitalização das fotos e dos mapas de campo.

Aos moradores do Jardim Brasítia e Vila Independência por sua grande receptividade, pelos seus importantes depoimentos e pela clareza das informações. 


\section{RESUMO}

Giuliano, RCS. Avatiação do impacto da protiferaçăo de odores ofensivos do tratamento de esgotos sobre a saúde e o bem estar públicos: ETE - Piracicamirim - Piracicaba - SP. São Paulo; 2002. [Tese de Doutorado - Faculdade de Saúde Pública da USP].

Objetivo. As estações de tratamento de esgoto no desempenho de suas atividades podem gerar impactos que repercutem sobre as populações vizinhas, não só positiva, como também negativamente. Dentre os impactos negativos do tratamento de esgotos, encontra-se a proliferação de odores ofensivos, um dos principais motivos de queixa contra as estações. Neste contexto, o objetivo deste trabalho consiste na avaliação do impacto da proliferação de odores ofensivos decorrentes da operação da ETE Piracicamirim, em Piracicaba - SP, por meio da análise da percepção da população vizinha à estação. Método. Com este propósito, realizou-se um levantamento de dados e informações junto à população compreendida pelo raio de $1 \mathrm{~km}$ ao redor da estação, utilizando-se como instrumento de pesquisa um questionário próprio para a caracterização do problema. Resultados. Os resultados obtidos demonstraram a relevância do impacto já que $94 \%$ dos entrevistados queixaram-se de maus odores atribuídos à estação. Quanto ao reconhecimento dos efeitos da exposição aos odores, $51 \%$ dos entrevistados apontaram a necessidade de fechar portas e janelas em decorrência dos odores; $41 \%$ afirmaram sofrer restrições no uso das áreas externas de suas residências; $23 \%$ queixaram-se de mau estar; e, $15 \%$ de doenças respiratórias. Conclusões. $O$ impacto da protiferação de odores caracterizou-se como uma questão de Saúde Pública, na medida em que influi principatmente no bem estar $e$, em menor proporção, por acarretar distúrbios físicos à população exposta ao problema. Verificou-se ainda, a eficiência do instrumento de pesquisa (questionário), o qual poderá ser aprimorado para a aplicação em novos estudos de caso. 
Descritores: Tratamento de Esgotos. Avaliação de Impactos. Odores Ofensivos. 


\section{SUMMARY}

Giuliano, RCS. Avaliação do impacto da proliferação de odores ofensivos do tratamento de esgotos sobre a saúde e o bem estar públicos: ETE - Piracicamirim - Piracicaba - SP [Assessment of the proliferation of offensive odors impact on the public health and well-being: ETE - Piracicamirim - Piracicaba - SP]. São Pauto (BR); 2002. [Tese de Doutorado - Faculdade de Saúde Pública da USP].

Objective. The operation of wastewater treatment plants can cause impacts that reflect on neighborhood, not just positive but negatively. Proliferation of offensive odors is one of those negative impacts and also the main reason of popular indisposition against the plants. In this way, the purpose of this thesis is the assessment of the protiferation of offensive odors impact due to the operation of Piracicamirim Wastewater Treatment Plant, in Piracicaba - SP, through anatysis of the neighborhood's view. Method. With this aim, a date survey was conducted with the people who live in a ray of $1 \mathrm{Km}$ from the plant, using a suitable checklist to detect the problem. Results. Results obtained proved the importance of the impact: $94 \%$ of the people complained of bad odors due to the plant. In the recognition of the odor exposition effects, $51 \%$ of the people indicated the need to close doors and windows because of the odors; $41 \%$ said they suffer restriction in use of their gardens and backyards; $23 \%$ complained of indisposition; and, $15 \%$ of breath diseases. Conclusions. Protiferation of odors impact was shown as a matter of Public Health, when it causes interference mainly on well-being and, in a less proportion, when it causes disturbance in the people exposed to the problem. Also the efficiency of the checklist was proved, and this instrument can be improved to application in new case studies.

Descriptors: Wastewater Treatment. Assessment of Impacts. Offensive Odors. 


\section{Lista de Figuras}

FIGURA 3.1

FIGURA 3.2

FIGURA 5.1

FIGURA 5.2

FIGURA 5.3

FIGURA 5.4

FIGURA 5.5

FIGURA 5.6

FIGURA 6.1

FIGURA 6.2

FIGURA 6.3

FIGURA 8.1

FIGURA 8.2

FIGURA 8.3

FIGURA 8.4
Geração de sulfetos e despreendimento de odor

Percepção de impactos decorrentes da operação da ETE -

Parque Dona Esther, em Cosmópolis - SP, por parte da população vizinha compreendida peto raio $(R)=500 \mathrm{~m}$; traçado ao redor da estação

ETE - Piracicamirim

36

Formação do Rio Piracicaba em Americana-SP

Bacia do Rio Piracicaba: Localização em Retação ao Estado 38 de SP

Vista aérea da ETE Piracicamirim

63

Reatores anaeróbios e tratamento de gás

63

Esquema do Tratamento de Esgoto - ETE - Piracicamirim

65

Representação esquemática de um reator UASB

73

Esquema de ETE convencionat com todos ativados

75

Esquema de ETE com reator UASB seguido de lodos 77 ativados

Sexo dos entrevistados $X$ Conhecimento (ou não) do órgão 97 de saneamento local

Sexo dos entrevistados $X$ Opinião sobre a disposição dos 98 esgotos

Sexo dos entrevistados $X$ Percepção do impacto da 99 proliferação de odores ofensivos do tratamento de esgotos

Sexo dos entrevistados $X$ Identificação da presença dos 100 odores ao longo do ano 
FIGURA 8.5

FIGURA 8.6

FIGURA 8.7

FIGURA 8.8

FIGURA 8.9

FIGURA 8.10

FIGURA 8.11

FIGURA 8.12

FIGURA 8.13

FIGURA 8.14

FIGURA 8.15

FIGURA 8.16

FIGURA 8.17

FIGURA 8.18

FIGURA 8.19
Sexo dos entrevistados $X$ Identificação da frequência dos

101 odores ao longo do dia

Sexo dos entrevistados $X$ Percepção de fatores agravantes

Sexo dos entrevistados $X$ Reconhecimento de efeitos da

103 exposição aos odores

Faixa etária dos entrevistados $X$ Conhecimento (ou não) do 106 órgão de saneamento local

Faixa etária dos entrevistados $X$ Opinião sobre a disposição 107 dos esgotos

Faixa etária dos entrevistados X Percepção do impacto da 108 proliferação de odores ofensivos do tratamento de esgotos

Faixa etária dos entrevistados $X$ Identificação da presença 109 dos odores ao longo do ano

Faixa etária dos entrevisfados $X$ Identificação da frequência 110 dos odores ao longo do dia

Faixa etária dos entrevistados $\times$ Percepção de fatores $1 \uparrow 1$ agravantes

Faixa etária dos entrevistados $X$ Reconhecimento de efeitos da exposição aos odores

Renda familiar $X$ Conhecimento (ou não) do órgão de 116 saneamento local

Renda familiar $X$ Opinião sobre a disposição dos esgotos

Renda familiar $X$ Percepção do impacto da proliferação de odores ofensivos do tratamento de esgotos

Renda familiar $X$ Identificação da presença dos odores ao 119 longo do ano

Renda familiar $X$ Identificação da frequência dos odores ao 120 longo do dia 
FIGURA 8.21

FIGURA 8.22

FIGURA 8.23

FIGURA 8.24

FIGURA 8.25

FIGURA 8.26

FIGURA 8.27

FIGURA 8.28

FIGURA 8.29

FIGURA 8.30

FGURA 8.31

FIGURA 8.32

FIGURA 8.33

FIGURA 8.34
Renda familiar $X$ Recontrecimento de efeitos da exposição aos odores

Escolaridade do entrevistado $X$ Conhecimento (ou não) do 125 órgão de saneamento local

Escotaridade do entrevistado $\times$ Opinião sobre a disposição 126 dos esgotos

Escolaridade do entrevistado $X$ Percepção do impacto da 127 proliferação de odores ofensivos do tratamento de esgotos

Escolaridade do entrevistado $X$ tdentificação da presença dos odores ao longo do ano

Escolaridade do entrevistado $X$ Identificação da frequência 130 dos odores ao longo do dia

Escotaridade do entrevistado $\times$ Percepção de fatores 134 agravantes

Escolaridade do entrevistado $X$ Reconhecimento de efeitos 132 da exposição aos odores

Procedência da família $\times$ Contrecimento (ou não) do órgão 135 de saneamento local

Procedência da familia $\times$ Opinião sobre a disposição dos $\uparrow 36$ esgotos

Procedência da famítia $X$ Percepção do impacto da 137 proliferação de odores ofensivos do tratamento de esgotos

Procedência da familia $X$ Identificação da presença dos 138 odores ao longo do ano

Procedência da família $X$ Identificação da frequência dos 139 odores ao longo do dia Procedência da familia $\times$ Percepção de fatores agravantes 
FIGURA 8.35

Procedência da família $X$ Reconhecimento de efeitos da exposição aos odores

FIGURA 8.36

ETE - Piracicamirim e seu entorno 


\section{Lista de Quadros e Tabelas}

\section{QUADRO 2.1}

QUADRO 2.2

QUADRO 2.3

QUADRO 3.1

QUADRO 3.2

QUADRO 4.1

QUADRO 5.1

QUADRO 5.2

QUADRO 5.3

QUADRO 5.4

QUADRO 5.5

QUADRO 5.6

QUADRO 5.7

QUADRO 5.8

QUADRO 5.9
Principais impactos ocasionados por estações de

tratamento de esgotos sanitários

Atributos dos impactos

10

Doenças relacionadas com as fezes

Emissōes de odores nas estações de tratamento de esgotos sanitários

Características dos principais compostos odorantes em estações de tratamento de esgotos

Efeitos produzidos pela exposição humana ao gás sulfídrico

Evolução populacional nos municípios da Bacia do Rio

Piracicaba de 1960 a 2000

Área Total e densidade demográfica dos municípios da

Bacia do Rio Piracicaba a partir de informaçōes do Censo Demográfico de 2000

População total por grupo de cidades

Bacias dos Rios Piracicaba e Capivari - Retrato do Uso das Âguas

Total da Poluição em $\mathrm{Kg}$ de $\mathrm{DBO}_{5} /$ dia

Bacias dos Rios Piracicaba e Capivari - Demandas para Irrigação

Sintese das Principais Diferenças entre o Consórcio Intermunicipal das Bacias dos Rios Piracicaba e Capivari e o $\mathrm{CBH}-\mathrm{PCJ}$

O SEMAE em Números 
TABELA 7.1

Determinação de uma amostra de populações finitas, para $p$

$=50 \%$ e os erros de estimação indicados (nivet de confiança de $95,5 \%)$

QUADRO 8.1 Direção pređominante e velocidade média dos ventos para $\uparrow 45$ os meses do ano 2000 


\section{ÍNDICE}

1. Introdução

$\begin{array}{ll}\text { 1.1. Objetivo } & 02\end{array}$

1.2. Hipótese 03

1.3. Sintese dos Capitulos 03

2. Principais Impactos Relacionados ao Tratamento de Esgotos Sanitários 06

3. Proliferação de Odores Ofensivos Decorrentes do Tratamento de Esgotos 17 Sanitários

$\begin{array}{lr}\text { 3.1. Definições Preliminares } & \uparrow 7\end{array}$

$\begin{array}{ll}\text { 3.2. Odor em Sistemas de Esgotos Sanitários } & 18\end{array}$

3.2.1. Odor na Rede Coletora de Esgotos 19

3.2.2. Odor em Estações de Tratamento de Esgotos 20

3.3. Repercussões Associadas aos Odores de ETEs 23

3.4. Controle de Odores em ETEs 27

4. Aspectos Toxicológicos Relacionados ao Sulfeto 29

4.1. Importância do Sulfeto nos Esgotos 29

4.2. Principais Compostos de Enxofre Ligados ao Tratamento de Esgotos 30

4.3. Ação Tóxica e Limite de Tolerância do $\mathrm{H}_{2} \mathrm{~S}$

4.4. Sintomatologia Relacionada à Intoxicação por $\mathrm{H}_{2} \mathrm{~S}$

$\begin{array}{ll}\text { 4.5. Primeiros Socorros e Tratamento } & 33\end{array}$

4.6. Prevenção de Acidentes no Ambiente de Trabalho 34

5. Objeto de Estudo de Caso: ETE - Piracicamirim - Piracicaba - SP 36 
5.1. Localização: A Região da Bacia do Rio Piracicaba

5.1.1. Importância Econômica e Social

5.1.2. Demanda pela Água e Poluição dos Recursos Hídricos

5.1.3. Histórico da Luta pela Despoluição dos Recursos Hidricos

49

5.1.4. O Comitê e o Consórcio das Bacias

51

5.2. Órgão Responsável: SEMAE - Piracicaba 56

5.2.1. Curiosidades Históricas

5.2.2. Estações de Tratamento de Esgotos

5.3. Dados de Projeto e Informações Complementares

5.3.2. Unidades, Autoria do Projeto e Consórcio Executor

6. Particularidades do Sistema Combinado de Trafamento de Esgotos Sanitários: Reator Anaeróbio (UASB) Seguido de Reator Aeróbio (Lodos Ativados)

6.1. Definições Preliminares

68

6.2. Reator Anaeróbio Seguido de Reator Aeróbio

6.2.1. Reator UASB

6.2.2. Lodos Ativados

6.3. Vantagens Específicas do Sistema Combinado: UASB e Lodos Ativados

7. Metodologia para Avaliação do Impacto da Proliferação de Odores Ofensivos do Tratamento de Esgotos Sanitários 
7.2.2. Método Utilizado: Questionário (Checklist)

7.3. Critérios de Amostragem

7.4. Determinação da Amostra

8. Estudo de Caso: Análise dos Resultados da Pesquisa de Campo

8.1. Indicadores da Percepção Popular

8.2. Comportamento das Variáveis em Relação aos Indicadores

8.3. Estrutura Política-Cultural dos Entrevistados

8.4. Percepção do Impacto em Relação à Localização das Residências

9. Conclusões e Recomendações

9.1. Considerações Gerais

9.2. Considerações Acerca do Estudo Empreendido

9.3. Observações e Recomendações Finais

10. Referências Bibliográficas

ANEXOS

ANEXO 1 "Questionário para avatiação da repercussão de odores decorrentes de estações de tratamento de esgotos sobre as populações circunvizinhas - Percepção da população com relação ao impacto"

ANEXO 2 "Termo de Consentimento Livre e Esclarecido" 


\section{Introdução}

As estações de tratamento de esgotos - ETEs - têm legitimado sua função social nos núcleos urbanos, principalmente por constituírem-se em instrumentos para a proteção dos corpos d'água, atém de propiciarem o combate às doenças de veiculação hídrica.

No Brasil, onde a intensificação do processo de urbanização tem resultado no aumento da demanda por água em quantidade e qualidade adequadas, e onde as doenças de veiculação hídrica ainda correspondem à $65 \%$ das internações hospitalares, os serviços de tratamento de esgotos devem ser efetivamente incentivados (BATTALHA \& PARLATORE, 1993; ABES, 1994).

Em contrapartida, por seu potencial gerador de impactos não apenas positivos, mas também negativos, há a necessidade de avaliação das repercussões do tratamento de esgotos, principalmente nos aspectos referentes aos efeitos adversos que podem indispor as populações vizinhas contra a operação das estações.

Em pesquisa anterior, correspondente à dissertação de mestrado "Avaliação dos Impactos Sociais nos Processos de Implantação e Gestão dos Serviços de Tratamento de Esgotos Sanitários", desenvolvida junto ao Departamento de Engenharia Civil da Universidade Federal de São Cartos (DECiv-UFSCar), apurou-se que a proliferação de odores ofensivos do tratamento de esgotos consistia na principal queixa dos moradores circunvizinhos às ETEs (DE SOUZA, 1998)

Uma vez que a protiferação de odores ofensivos tem sido apontada como um dos principais transtornos decorrente da operação das estações de tratamento de esgotos sanitários, torna-se importante a compreensão do problema, suas origens e seus agravantes. 
Neste contexto, buscou-se empreender um estudo de caso que abordasse a questão sob a ótica da população afetada, ou seja, os moradores vizinhos à ETE.

Em razão de sua importância econômica e social e pelo histórico de combate à poluição dos recursos hídricos, selecionou-se previamente a Região da Bacia do Rio Piracicaba e dentre as estações visitadas, a ETE Piracicamirim em Piracicaba - SP, a qual já apresentava várias queixas de incômodos devido aos odores exalados.

Assim sendo, esta tese de doutoramento visa complementar o trabalho iniciado no mestrado, enfocando o impacto que sobressaiu-se dentre todos como o de maior e pior repercussão entre os vizinhos de ETEs: a protiferação de odores ofensivos decorrente do tratamento de esgotos sanitários.

\subsection{Objetivo}

O objetivo deste trabalho consiste na avaliação do impacto da proliferação de odores ofensivos decorrentes da operação da ETE Piracicamirim, em Piracicaba - SP, por meio da anátise da percepção da população vizinha à estação.

Com este objetivo, foi realizado um levantamento de dados $e$ informações junto à população compreendida no raio de $1 \mathrm{Km}$ ao redor da estação, utilizando-se como instrumento de coleta de dados, um questionário próprio para a caracterização do problema.

O questionário, composto de 38 questões objetivas, foi desenvolvido para permitir uma rápida identificação do entrevistado, das condições sócio- 
econômicas familiares, da estrutura domiciliar e da acessibilidade aos equipamentos urbanos, além de sua opinião acerca de questões tigadas à empresa de saneamento local e ao tratamento de esgotos, do nível de interferência dos odores da ETE em sua vida pessoal e social e, em parte, de seu perfil político-cultural.

$\mathrm{Na}$ apticação do questionário, utitizou-se de critérios de amostragem para a determinação de uma amostra representativa da população estudada, ou seja, os moradores da circunvizinhança da ETE - Piracicamirim. Na escolha das residências a serem visitadas, respeitou-se o critério de aleatoriedade, com o sorteio das casas.

Em todo o tempo de abordagem, procurou-se garantir o anonimato dos entrevistados quando da divulgação dos resultados, como forma de assegurar-lhes a liberdade de expressão, sem medo de críticas ou represátias posteriores, de quaisquer ordem ou procedência.

\subsection{Hipótese}

A hipótese que se buscou verificar através da pesquisa empreendida, é a seguinte:

"A proliferação de odores ofensivos decorrente da operação da ETE Piracicamirim, em Piracicaba - SP, repercute negativamente sobre a saúde e o bem estar da população vizinha, compreendida pelo raio de $1 \mathrm{~km}$ ao redor da estação". 


\subsection{Síntese dos Capítulos}

Nos capitutos a seguir, são apresentados os resultados da pesquisa, após uma descrição mais detalhada e aprofundada do tema enfocado, do objeto de estudo de caso e da metodologia empregada.

Desta forma, o capitulo 2, trata dos principais impactos relacionados ao tratamento de esgotos sanitários, tanto os positivos quanto os negativos, nas fases de implantação e de operação das estações. Situa a proliferação de odores ofensivos como um dos impactos negativos decorrentes da operação de ETEs e ainda entre os principais motivos de queixa das populações vizinhas. Apresenta a classificação dos diversos impactos segundo seus atributos, e aponta para a necessidade de um planejamento adequado da ETE, com a previsão de impactos potenciais e a análise das alternativas existentes para o tratamento de esgotos, em cada caso particutar.

No capítulo 3, a questão da proliferação de odores ofensivos é abordada nos aspectos que vão desde a definição de odor, da identificação do principal causador do mau cheiro $\left(\mathrm{H}_{2} \mathrm{~S}\right)$ e da descrição do processo de produção do mesmo em esgotos sanitários, até as consequências da exposição continuada sobre a saúde e 0 bem estar de operadores e populações próximas às ETEs.

O capitulo 4 apresenta uma breve discussão sobre os aspectos toxicológicos relacionados ao sulfeto $\left(\mathrm{H}_{2} \mathrm{~S}\right)$. Discorre sobre a importância do sulfeto nos esgotos, os principais compostos de enxofre ligados ao tratamento de esgotos, ação tóxica e limite de tolerância do $\mathrm{H}_{2} \mathrm{~S}$, sintomatologia relacionada à intoxicação por $\mathrm{H}_{2} \mathrm{~S}$, primeiros socorros, tratamento e prevenção de acidentes no ambiente de trabalho.

O objeto de estudo de caso, ou seja, a ETE - Piracicamirim em Piracicaba - SP, é descrita no capítulo 5, onde se busca apresentar alguns 
aspectos que contribuiram significativamente para a sua escolha e que também permitem caracterizá-la, tais como: localização, órgão de saneamento responsável, dados de projeto, entre outros.

No capítulo 6, são apresentadas particularidades do sistema combinado de tratamento de esgotos sanitários: reator UASB seguido por lodos ativados, empregado na ETE - Piracicamirim. Primeiramente trata-se de algumas definições básicas e necessárias para a compreensão de sistemas combinados, logo depois, discorre-se sobre as vantagens do uso combinado de reatores anaeróbios e aeróbios e mais especificamente, do sistema "UASB e lodos ativados", que é o empregado na ETE Piracicamirim.

Os aspectos relativos à metodologia de pesquisa são abordados no capitulo 7, onde trata-se da eleição do objeto de estudo de caso, da reestruturação da metodotogia de trabatho, dos critérios de amostragem e da determinação da amostra para a aplicação do questionário.

O capítulo 8, traz a análise dos principais resultados obtidos na pesquisa de campo, com as entrevistas realizadas através do questionário. Nesta análise, optou-se por abordar a questão do impacto da protiferação de odores ofensivos do tratamento de esgotos, elegendo-se algumas variáveis e indicadores considerados essenciais à compreensão do problema.

Finalmente, o capitulo 9 apresenta as conclusões a que se chegou com o desenvolvimento dos trabalhos e ainda, algumas recomendações que podem vir a servir como incentivo e contribuição para novas pesquisas na área. 


\section{Principais Impactos Relacionados ao Tratamento de Esgotos Sanitários}

A utilização dos corpos d'água como receptores de esgotos sanitários, tem sido, ao longo dos anos, a solução mais adequada para o seu rápido afastamento dos núcleos urbanos. No entanto, quando estes esgotos são lançados "in natura", ou seja, sem nenhuma espécie de tratamento prévio, a poluição e a consequente contaminação dos recursos hídricos, acabam por ocasionar distúrbios que irão se refletir sobre as populações urbanas, tais como o comprometimento gradativo das atividades de pesca e recreação em rios e córregos (FORESTI et al., 1980).

Há de se considerar também, os efeitos desastrosos que a poluição dos recursos hídricos por esgotos sanitários ocasionam sobre as populações à jusante dos lançamentos. Uma vez que a capacidade dos corpos d'água de se auto purificarem (autodepuração) é comprometida pelo lançamento de altas cargas poluidoras, isso resultará no abandono dos mesmos como mananciais (em potencial) de abastecimento público de água, ou ainda para que esses possam ser utilizados, os gastos decorrentes do tratamento para tornar a água própria ao consumo humano, acabam por inviabilizar esta utilização (BATTALHA \& PARLATORE, 1993).

No que diz respeito à veiculação de doenças através da água contaminada com organismos patogênicos provenientes dos esgotos sanitários, têm-se que $65 \%$ das internações hospitalares no Brasil estão relacionadas com a disposição inadequada dos esgotos, ou seja, decorrem do lançamento dos esgotos sanitários sem tratamento (ABES,1994).

Desta forma, a implantação de estações de tratamento de esgotos sanitários - ETEs apresenta-se como importante instrumento de apoio à Preservação Ambiental (redução da carga potuidora dos rios), à Quatidade 
de Vida (água de qualidade e em quantidade suficientes para $\circ$ abastecimento público) e à Saúde Pública (prevenção às doenças de veiculação hídrica).

Em contrapartida, as ETEs também podem vir a acarretar repercussões negativas sobre as populações que residem em seu entorno, das quais se destacam, principatmente, a proliferação de odores ofensivos, insetos e outros vetores.

Principalmente para o setor de saneamento, o estudo destas perturbações tem assumido um papel de considerável importância para as agências interessadas em manter um relacionamento saudável com seus usuários-clientes (ABES, 1995).

O chamado efeito "NIMBY" - "not in my back-yard" ou em português: "não no meu quintal" - tem mobilizado profissionais da área de saneamento, interessados em controlar os incômodos sofridos pelas populações vizinhas, à empreendimentos como estações de tratamento de esgotos (JOHNSTONE, 1996; ANDRADE et at., 2001).

A própria população vizinha ao empreendimento tem sido convocada a contribuir para a eficiência da aplicação dos métodos de controle destes incômodos, denunciando a ação dos mesmos e cobrando a rápida intervenção dos órgãos responsáveis (MONTENEGRO et al., 1996).

Um outro efeito que vem merecendo a atenção das empresas de saneamento é conhecido como efeito "NIMP" - "not in my pocket" ou em português: "não no meu bolso" - que reflete a resistência da população aos aumentos de tarifas dos serviços de saneamento, mesmo que tais aumentos sejam em virtude da melhoria dos serviços (MONTENEGRO et al., 1996).

Em relação ao efeito "NIMP", pode-se afirmar que em uma comunidade urbana, além de uma parcela de baixa renda que no processo de exclusão social acaba por não se beneficiar das methorias implementadas (não acesso ao saneamento básico) e que por isso mesmo 
não deve arcar com o ônus daquilo de que não usufrui, existem aqueles que consideram que os serviços de saneamento devern ser formecidos gratuitamente, sendo esta uma responsabilidade governamental; e outros que reconhecem a necessidade de pagar pelos serviços, mas que não compreendem o valor das despesas que são repassadas para as tarifas, considerando-as portanto, muito altas (JOHNSTONE, 1996).

Para a recuperação de investimentos e consequente expansão dos serviços, beneficiando assim uma parcela maior da população, é de fundamental importância a conscientização dos usuários com respeito ao pagamento das tarifas dos serviços de saneamento. Neste sentido, as agências ou órgãos responsáveis devem procurar incrementar seu relacionamento com a comunidade, colocando-a a par de seus projetos e orçamentos.

O conhecimento dos impactos retacionados às ETEs gera subsídios para a realização de um planejamento adequado das obras futuras. Em todo esse processo, é de suma importância, o que já vem sendo detectado e implantado por agências interessadas em manter um bom relacionamento com seus usuários, como a criação dos chamados "Consethos de Consumidores" por algumas empresas de saneamento (ABES, 1995).

Tanto durante a construção, como na operação de estações de tratamento de esgotos sanitários, são produzidos impactos que incidem principalmente sobre as populações vizinhas, atguns trazendo beneficios "impactos positivos" - e outros incômodos - "impactos negativos".

$O$ estudo e o planejamento adequado da ETE, bem como a previsão dos impactos potenciais em suas fases de implantação e gestão, são essenciais ao bom funcionamento e à aceitação da obra pela população, contribuindo para a otimização dos impactos positivos e para o controle ou minimização dos impactos negativos, que devem se constituir em objetivos a serem alcançados pelas empresas responsáveis pelos serviços de saneamento. 
O Quadro 2.1 apresenta os principais impactos relacionados à Estações de Tratamento de Esgotos Sanitários, os quais foram identificados a partir de revisão da literatura existente.

\section{QUADRO 2.1 - Principais impactos ocasionados por estações de tratamento de esgotos sanitários}

\begin{tabular}{|c|c|c|c|}
\hline \multicolumn{4}{|c|}{ Impactos relativos à Fase 1 - Im plantação } \\
\hline & Impacto & $\begin{array}{c}\text { Referéncia } \\
\text { Bibliográfica } \\
\end{array}$ & Atributos \\
\hline 1 & $\begin{array}{c}\text { geração de empregos e } \\
\text { aumento das atividades } \\
\text { comerciais }\end{array}$ & MCMAHON, 1982 & $\begin{array}{l}\text { positivo, constante, temporário, direto, } \\
\text { regionat, imediato e reversivel }\end{array}$ \\
\hline 11 & problemas com ruídos & $\begin{array}{l}\text { VON SPERLING } \\
1994\end{array}$ & $\begin{array}{l}\text { negativo, intermitente, temporário, } \\
\text { direto, local, imediato e reversivel }\end{array}$ \\
\hline III & $\begin{array}{c}\text { dispersão de material } \\
\text { particulado }\end{array}$ & SABESP, 1989 & $\begin{array}{l}\text { negativo, intermitente, temporário, } \\
\text { direto, local, imediato e reversivel }\end{array}$ \\
\hline IV & $\begin{array}{l}\text { desvalorização dos imóveis ao } \\
\text { redor da estação }\end{array}$ & MCMAHON, 1982 & $\begin{array}{l}\text { negativo, constante, permanente, } \\
\text { direto, local, imediato e irreversivel }\end{array}$ \\
\hline $\mathrm{V}$ & $\begin{array}{c}\text { aumento do tráfego de veículos } \\
\text { pesados }\end{array}$ & SABESP, 1989 & $\begin{array}{l}\text { negativo, intermitente, temporário, } \\
\text { indireto, local, imediato e reversivel }\end{array}$ \\
\hline \multicolumn{4}{|c|}{ Impactos relativos à Fase 2 - Operação } \\
\hline & Impacto & $\begin{array}{c}\text { Referência } \\
\text { Bibliográfica } \\
\end{array}$ & Atributos* \\
\hline 1 & $\begin{array}{c}\text { geraçāo de empregos e } \\
\text { aumento das atividades } \\
\text { comerciais }\end{array}$ & MCMAHON, 1982 & $\begin{array}{l}\text { positivo, constante, temporário, direto, } \\
\text { regional, imediato e reversivel }\end{array}$ \\
\hline II & $\begin{array}{l}\text { melhoria da Saúde Pública } \\
\text { (decréscimo nos indices de } \\
\text { morbidade e de mortalidade } \\
\text { infantil) }\end{array}$ & $\begin{array}{c}\text { SILVA \& MARA } \\
1979\end{array}$ & $\begin{array}{c}\text { positivo, constante, permanente, } \\
\text { direto, regional, a médio prazo e } \\
\text { reversivel }\end{array}$ \\
\hline III & $\begin{array}{c}\text { melhoria na Qualidade da Vida } \\
\text { Urbana (incremento da } \\
\text { infraestrutura e serviços) }\end{array}$ & MCMAHON, 1982 & $\begin{array}{c}\text { positivo, constante, permanente, } \\
\text { direto, regional, a médio prazo e } \\
\text { reversivel }\end{array}$ \\
\hline IV & $\begin{array}{c}\text { melhoria na Qualidade } \\
\text { Ambiental (rios) }\end{array}$ & $\begin{array}{l}\text { VON SPERLING, } \\
1994\end{array}$ & $\begin{array}{c}\text { positivo, constante, permanente, } \\
\text { direto, regional, a médio prazo e } \\
\text { reversivel }\end{array}$ \\
\hline $\mathrm{V}$ & produção de alimentos (peixes) & CETESB, 1975 & $\begin{array}{l}\text { positivo, constante, permanente, } \\
\text { direto, regional, a médio prazo e } \\
\text { reversivel }\end{array}$ \\
\hline VI & $\begin{array}{l}\text { desvalorização dos imóveis ao } \\
\text { redor da estação }\end{array}$ & MCMAHON, 1982 & $\begin{array}{l}\text { negativo, constante, permanente, } \\
\text { direto, local, imediato e ifreversivel }\end{array}$ \\
\hline VII & $\begin{array}{c}\text { proliferaçăo de odores } \\
\text { ofensivos }\end{array}$ & $\begin{array}{l}\text { VON SPERLING, } \\
1994\end{array}$ & $\begin{array}{l}\text { negativo, intermitente, temporário, } \\
\text { direto, local, imediato e reversivel }\end{array}$ \\
\hline VIII & $\begin{array}{l}\text { aumento das tarifas dos } \\
\text { serviços de saneamento }\end{array}$ & $\begin{array}{l}\text { VON SPERLING, } \\
1994\end{array}$ & $\begin{array}{c}\text { negativo, constante, permanente, } \\
\text { direto, regional, a médio prazo e } \\
\text { reversivel }\end{array}$ \\
\hline IX & proliferação de insetos & $\mathrm{NUCCl}, 1978$ & $\begin{array}{c}\text { negativo, constante, permanente, } \\
\text { indireto, local, a médio prazo e } \\
\text { irreversível }\end{array}$ \\
\hline $\bar{x}$ & formaçăo de aerossóis & NUCCI, 1978 & $\begin{array}{l}\text { negativo, intermitente, direto, local, } \\
\text { imediato e reversivel }\end{array}$ \\
\hline
\end{tabular}

Fonte: DE SOUZA \& SALVADOR, 1997 modificado.

* Classificação extraída de SABESP, 1989. 
Os atributos dos impactos que se observam no Quadro 2.1, baseiamse nos critérios de valoração qualitativa que levam em conta fatores tais como: influência, periodicidade, duração, causalidade, abrangência geográfica, carência e reversibilidade dos impactos (LEOPOLD et at., 1971 apud TOMASI, 1993).

No Quadro 2.2, apresenta-se um resumo explicativo acerca dos atributos dos impactos e suas possiveis classificações.

QUADRO 2.2 - Atributos dos Impactos

\begin{tabular}{|c|c|}
\hline Influência & Positivo (benéfico) ou Negativo (adverso) \\
\hline Periodicidade & Cíclico, Intermitente ou Constante. \\
\hline Duração & Permanente ou Temporário. \\
\hline Causatidade & Direto ou Indireto. \\
\hline Abrangência Geográfica & Local ou Regional. \\
\hline Carência & Imediato ou a Médio ou a Longo Prazo. \\
\hline Reversibilidade & Reversivel ou IrTeversivel. \\
\hline
\end{tabular}

Fonte: LEOPOLD et al., 1971 apud TOMASI, 1993.

Com relação aos impactos relativos à fase de implantação da ETE, tem-se como efeito positivo a geração de empregos, a qual evidencia-se na contratação de pessoal para a execução da obra e ainda nas relações comerciais caracteristicas do empreendimento, como aquisição da área, compra de materiais para a construção, locação de equipamentos pesados, etc. A quantidade de empregos gerados durante a construção da estação, é dada em função do porte da obra, sendo que os mesmos podem ser diretos (trabalhadores da construção civil) ou indiretos (em razão do incremento das atividades comerciais). 
Também como impactos relacionados à implantação da estação, têmse os efeitos negativos caracterizados por ruídos, poeira e tráfego de veículos pesados, que ocasionam distúrbios e perturbações às pessoas que compartitham do espaço no entorno da ETE, quer para moradia, ou no desempenho de atividades de trabalho, escolares ou recreativas. São impactos próprios à construção da obra, apresentando maior ou menor intensidade em virtude do tamanho do empreendimento e das providências tomadas visando ao seu controle.

Um impacto negativo e de vital importância corresponde à desvatorização dos imóveis ao redor da estação, o quat encontra-se relacionado à expectativa causada pela implantação da obra, sendo um impacto da fase de implantação e que persiste durante a operação da ETE, onde fica mais evidente o desagrado dos vizinhos insatisfeitos com a obra "em seu quintal" - efeito "NIMBY". A repercussão deste impacto pode ser agravada se não forem tomadas medidas eficazes ao seu controle.

A geração de empregos na fase de operação da estação assume uma conotação diferente da fase anterior. Os empregos gerados durante a construção eram temporários (apenas enquanto a obra estava sendo implantada), já com a ETE em funcionamento, a duração dos novos empregos passa a ser de caráter permanente (por toda a vida útil da ETE), o que requer mão de obra treinada especialmente para este fim. Outra vez, o porte da estação é que determinará a quantidade de empregos a serem gerados.

Outro impacto positivo decorrente da operação de ETEs, diz respeito à melhoria da Saúde Pública, o que constitui um forte argumento para a defesa da prática do tratamento de esgotos. Uma vez que as doenças de veiculação hídrica contribuem diretamente para a diminuição da capacidade produtiva dos indivíduos, comprometendo sua força de trabatho, além de ocasionar a morte de crianças e de adultos susceptíveis, a expectativa em torno da redução dos índices de morbidade e mortalidade, tem motivado esforços no sentido de se difundir o tratamento dos esgotos sanitários. 
No Quadro 2.3, são apontadas algumas caracteristicas das principais doenças relacionadas com as fezes e sua relação com os esgotos sanitários e águas contaminadas.

QUADRO 2.3 - Doenças relacionadas com as fezes

\begin{tabular}{|c|c|c|c|}
\hline $\begin{array}{l}\text { Grupo de } \\
\text { Doenças }\end{array}$ & Formas de Transmissão & $\begin{array}{c}\text { Principais } \\
\text { Doenças }\end{array}$ & $\begin{array}{r}\text { Formas de } \\
\text { Prevenção } \\
\end{array}$ \\
\hline $\begin{array}{l}\text { Feco-orais } \\
\text { (não } \\
\text { bacterianas) }\end{array}$ & $\begin{array}{l}\text { Contato de pessoa para } \\
\text { pessoa, quando náo se } \\
\text { tem higiene pessoal e } \\
\text { doméstica adequada. }\end{array}$ & $\begin{array}{l}\text {-poliomielite } \\
\text { - hepatite tipo A } \\
\text {-giardiase } \\
\text {-disenteria amebiana } \\
\text {-diarréia por virus }\end{array}$ & $\begin{array}{l}\text {-implantar sistema de } \\
\text { abastecimento de água; } \\
\text {-melhorar as moradias e } \\
\text { as instalaçóes sanitárias; } \\
\text { - promover a educação } \\
\text { sanitária. }\end{array}$ \\
\hline $\begin{array}{c}\text { Feco-orais } \\
\text { (bacterianas) }\end{array}$ & $\begin{array}{l}\text { Contato de pessoa para } \\
\text { pessoa, ingestazo e } \\
\text { contato com alimentos } \\
\text { contaminados e contato } \\
\text { com fontes de aguas } \\
\text { contaminadas pelas } \\
\text { fezes. }\end{array}$ & $\begin{array}{l}\text {-febre tifóide } \\
\text {-febre paratifóide } \\
\text {-diarréias e disenterias } \\
\text { bacterianas, como a } \\
\text { cótera }\end{array}$ & $\begin{array}{l}\text {-implantar sistema de } \\
\text { abastecimento de água; } \\
\text {-promover a educação } \\
\text { sanitária; } \\
\text {-implantar um sistema } \\
\text { adequado de disposição } \\
\text { de esgotos. }\end{array}$ \\
\hline $\begin{array}{l}\text { Helmintos } \\
\text { transmitidos } \\
\text { pelo solo }\end{array}$ & $\begin{array}{l}\text { Ingestão de alimentos } \\
\text { contaminados e contato } \\
\text { da pele com o solo. }\end{array}$ & $\begin{array}{l}\text {-ascaridiase (lombriga) } \\
\text {-tricuriase } \\
\text {-ancilostomiase } \\
\text { (amareláo) }\end{array}$ & $\begin{array}{l}\text {-construir e manter limpas } \\
\text { as instalaçóes sanitárias; } \\
\text {-tratar os esgotos antes } \\
\text { da disposiçăo no solo; } \\
\text {-evitar contato direto da } \\
\text { pele com o solo (usar } \\
\text { calçado). }\end{array}$ \\
\hline $\begin{array}{c}\text { Tênias } \\
\text { (solitátias) na } \\
\text { carne de boi e } \\
\text { de porco }\end{array}$ & $\begin{array}{l}\text { Ingestăo de carne mal } \\
\text { cozida de animais } \\
\text { infectados. }\end{array}$ & $\begin{array}{l}\text {-teniase } \\
\text {-cisticercose }\end{array}$ & $\begin{array}{l}\text {-construir instalações } \\
\text { sanitánias adequadas; } \\
\text {-tratar os esgotos antes } \\
\text { da disposiçăo no soto; } \\
\text {-inspecionar a carne e ter } \\
\text { cuidados na sua } \\
\text { preparaçăo (cozimento). }\end{array}$ \\
\hline $\begin{array}{l}\text { Helmintos } \\
\text { associados à } \\
\text { água }\end{array}$ & $\begin{array}{l}\text { Contato da pele com água } \\
\text { contaminada. }\end{array}$ & -esquitossomose & $\begin{array}{l}\text {-construir instalações } \\
\text { sanitárias adequadas; } \\
\text {-tratar os esgotos antes } \\
\text { do lançamento em curso } \\
\text { d'água; } \\
\text {-controtar os caramujos; } \\
\text {-evitar contato com água } \\
\text { contaminada (banho, } \\
\text { etc.). }\end{array}$ \\
\hline $\begin{array}{l}\text { Insetos vetores } \\
\text { relacionados } \\
\text { com as fezes }\end{array}$ & $\begin{array}{l}\text { Procriação em locais } \\
\text { contaminados pelas } \\
\text { fezes. }\end{array}$ & -filariose (elefantiase) & $\begin{array}{l}\text {-combater os insetos } \\
\text { transmissores; } \\
\text {-eliminar condições que } \\
\text { possam favorecer } \\
\text { criadouros; } \\
\text {-evitar o contato com } \\
\text { criadouros e utilizar meios } \\
\text { de proteção individual. }\end{array}$ \\
\hline
\end{tabular}

Fonte: BARROS, R.T.V. et al, 1995. 
A Saúde Pública pode ser definida como sendo a ciência e a arte de prevenir a doença, prolongar a vida e promover a saúde e a eficiência física e mental, através de esforços organizados da comunidade para o saneamento do meio e controle de doenças infecto-contagiosas, promover a educação do indivíduo em princípios de higiene pessoal, a organização de serviços médicos e de enfermagem para o diagnóstico precoce e tratamento preventivo das doenças, assim como o desenvolvimento da maquinária social de modo a assegurar, a cada indivíduo da comunidade, um padrão de vida adequado à manutenção da saúde (FNS, 1999; FSESP, 1981)

Sendo assim, o tratamento de esgotos sanitários apresenta sua contribuição para este "saneamento do meio urbano", desempenhando seu papel de importante instrumento ao combate às doenças de veiculação hidrica.

A melhoria da Qualidade da Vida Urbana com o incremento da infraestrutura e serviços urbanos, deve-se ao fato da conquista da estação de tratamento de esgotos (ETE) por parte das populações urbanas por ela atendidas, que passam a contar com mais este serviço público de saneamento.

Saneamento é o modo de vida, é a qualidade de viver, expressa em condiçōes de salubridade, com casa limpa, comércio e indústrias limpos, fazendas limpas. Sendo um modo de vida, deve vir do povo, ser alimentado pelo saber e crescer como um ideal e uma obrigação nas relações humanas (FNS, 1999; FSESP, 1981).

Neste sentido, a melhoria da Qualidade da Vida Urbana consiste em um impacto positivo na medida em que contribui para melhores condições de higiene e salubridade da cidade e das habitações (AZEVEDO NETTO \& BOTELHO, 1991).

Quanto à melhoria da Qualidade Ambiental, tem-se que com a operação da estação de tratamento de esgotos diminui-se a carga poluidora 
lançada diariamente nos cursos d'água, contribuindo para a preservação dos recursos hidricos e consequente melhoria na disponibitidade de água em quantidade e qualidade adequadas.

Intimamente ligado à melhoria da Qualidade Ambiental, está o impacto da produção de alimentos (peixes), que de igual forma apresenta uma influência positiva. Com a melhoria das águas de rios e lagos, tem-se o desenvolvimento da flora e da fauna aquática, contribuindo para o incremento da pesca, que proporciona às populações ribeirinhas a melhoria de seus padrões alimentares e econômicos, através do consumo e da venda do pescado (HOLLANDA, 1996)

O impacto da proliferação de odores ofensivos constitui um dos principais motivos de queixa das populações vizinhas às ETEs, contribuindo significativamente para a indisposição popular e, por se tratar do objeto de estudo deste trabatho, será tratado em um capitulo à parte.

$O$ aumento das tarifas dos serviços de saneamento em consequência do funcionamento da ETE, pode vir a comprometer a imagem da estação frente à população urbana, por se tratar de mais um item de despesa adicionado às taxas e impostos por serviços públicos prestados.

A conscientização da comunidade, acerca da importância da ETE para a sua própria saúde e bem estar, pode ser estimulada pela existência de uma comunicação saudável entre usuários e empresas de saneamento, o que irá contribuir para um consenso em torno das tarifas a serem cobradas pelo tratamento de esgotos sanitários (ELIAS \& VASQUES, 1971; WHO, 1994)

A proliferação de insetos acarreta transtomos aos operadores da ETE e às populações vizinhas à estação. Este impacto está relacionado principalmente às técnicas de tratamento tais como a disposição de esgoto no solo e as lagoas de estabilização. 
Além da irritação provocada por certos tipos de moscas e mosquitos que costumam surgir em decorrência do tratamento dos esgotos, a presença de insetos e vetores está associada à transmissão de doenças.

O planejamento adequado da ETE, desde a sua localização e construção até o treinamento de pessoal para a operação dos processos de tratamento, são providências que devem ser tomadas como forma de se prevenir este impacto desagradável.

A formação de aerossóis - gotículas de esgotos em suspensão no ar - é um impacto negativo característico do emprego de algumas técnicas de tratamento como o sistema de lodos ativados e a disposição de esgotos no solo.

Também para o caso da formação de aerossóis, mais uma vez, o adequado planejamento e operação da estação de tratamento de esgotos, podem contribuir para o controle ou minimização deste efeito indesejado.

Em relação aos impactos do tratamento de esgotos sanitários apresentados neste capítulo, tem-se que para que uma ETE apresente um desempenho satisfatório, com seus efeitos benéficos (impactos positivos) otimizados e tendo controlados, ou ao menos, minimizados os seus efeitos adversos (impactos negativos), é essencial que sejam analisadas todas as possiveis attemativas para o tratamento de esgotos, bem como os impactos potenciais para cada uma destas alternativas, em cada situação de esgoto a ser tratado e de população a ser atendida.

$\mathrm{Na}$ busca da solução para a questão do tratamento de esgotos de uma cidade, deve-se lançar mão dos instrumentos existentes para a previsão dos impactos potenciais e de medidas mitigadoras (no caso de impactos indesejados) e otimizadoras (para impactos desejados), tais como: o Relatório Ambiental Preliminar - RAP; o Estudo de Impacto Ambiental - EIA e o Relatório de Impacto Ambiental - RIMA. Instrumentos estes, integrantes do conjunto de estudos utilizados na Avaliação de Impacto Ambiental - AlA, 
os quais devem ser utilizados para identificar, predizer, interpretar e prevenir os efeitos ou consequências advindas das escolhas possiveis.

Durante os últimos anos, verificou-se uma verdadeira evolução nos conceitos concernentes ao tratamento de esgotos, com o crescimento do número de alternativas para o tratamento e o desenvolvimento da tecnologia de projeto, construção e operação das ETEs (CAMPOS, 1994).

Considerando-se que, atualmente, encontram-se disponiveis muitas alternativas para o tratamento de esgotos, desde uma simples, porém controlada disposição no solo ou em áreas improdutivas, até sofisticadas estações completamente automatizadas, devem ser ponderadas todas as possibilidades existentes e analisadas à exaustão as condições econômicas, ambientais e sociais, para que se chegue, realmente, à solução mais apropriada para uma determinada cidade. 


\section{Proliferação de Odores Ofensivos Decorrente do Tratamento de Esgotos Sanitários}

\subsection{Definições Preliminares}

Odor é definido como a sensação resultante da recepção de um estímulo pelo sistema olfativo. As respostas humanas ao estímulo de um odor específico, dependem de sua propriedade de ser mensurado, o que inclui aspectos tais como intensidade, detectabilidade e sentimento de prazer ou desprazer por ele ocasionado (BUONICORE \& DAVIS, 1992).

Também pode-se definir "odor" como sendo uma mistura de moléculas orgânicas ou minerais voláteis com propriedades físico-químicas distintas que afetam sensorialmente a mucosa nasal.

Os odores podem ser atribuídos à predominância de um composto peculiar $\left(\mathrm{H}_{2} \mathrm{~S}\right.$, por exemplo) ou a misturas complexas de moléculas orgânicas ou minerais voláteis.

No que tange à qualidade do ar, os odores e os materiais particulados (poeira) constituem os incômodos mais fortemente $e$ imediatamente percebidos pela população.

Quanto à origem, os odores podem ser resultantes das mais diversas atividades do homem, sejam agrícolas, domésticas ou industriais, tais como: indústrias petroquímicas e químicas, processamento de madeira, indústria de papel e celulose, pinturas e fabricação de tintas, resíduos sólidos, estações de tratamento de esgotos, dentre outras (BELLI FILHO \& DE MELO LISBOA, 1998). 


\subsection{Odor em Sistemas de Esgotos Sanitários}

Os odores característicos dos esgotos são causados pelos gases formados no processo de decomposição da matéria orgânica. Há alguns tipos principais de odores, bem característicos:

- odor de mofo, razoavelmente suportável, típico do esgoto fresco;

- odor de ovo podre, "insuportável", típico do esgoto velho ou séptico, que ocorre devido à formação de gás sulfídrico proveniente da decomposição do lodo contido nos despejos; e

- odores variados, de produtos podres, como de repolho, legumes, peixe, podres; de matéria fecal; de produtos rançosos; de acordo com a predominância de produtos sulfurosos, nitrogenados, ácidos orgânicos, etc.

Quando ocorrem odores diferentes e especificos, o fato se deve à presença de despejos industriais.

Num sistema de esgotos, o mau cheiro geralmente é observado na entrada da estação de tratamento e nas elevatórias, uma vez que são as estruturas abertas do sistema, onde o odor eventual poderá se expandir. Dentro do sistema coletor, o odor não chega a afetar o meio externo, salvo em casos de excepcional intensidade, quando pode alcançar as ruas através de tampões e ralos.

Nas estações de tratamento, o odor pode advir também dos depósitos de material gradeado, de areia, e nas operações de transferência e manuseio de lodo. Assim, uma atenção especial deverá ser dada às unidades que mais podem apresentar esses odores desagradáveis, como é caso das grades na entrada da ETE, das caixas de areia, e dos adensadores de lodo, por exemplo (JORDÃO \& PESSÔA, 1995). 
O QUADRO 3.1 apresenta os principais pontos de emissão e os niveis de concentração dos odores em uma estação de tratamento de esgotos sanitários.

QUADRO 3.1 - Emissões de odores nas estações de tratamento de esgotos sanitários

\begin{tabular}{|l|c|c|}
\hline \multirow{2}{*}{ Pontos na ETE } & \multicolumn{2}{c|}{ Concentrações médias $\left(\mathrm{mg} / \mathbf{m}^{\mathbf{3}}\right)$} \\
\cline { 2 - 3 } & Gás sulfídrico $\left(\mathrm{H}_{2} \mathrm{~S}\right)$ & Amônia $\left(\mathrm{NH}_{3}\right)$ \\
\hline Estação elevatória & 4,80 & 0,25 \\
\hline Unidades de pré-tratamento & 3,50 & 0,50 \\
\hline Decantador & 0,50 & 0,07 \\
\hline Sistema de lodos ativados & 0,40 & 0,07 \\
\hline Espessador de lodo & 9,80 & 0,80 \\
\hline Sistema de desidratação de lodo & 6,50 & 0,85 \\
\hline Sistema de disposição final de lodo & 0,40 & 7,00 \\
\hline
\end{tabular}

Fonte: BONNIN et at. (1993) apud BELLI FILHO et at. (2001b).

\subsubsection{Odor na Rede Coletora de Esgotos}

A FIGURA 3.1 indica a geração de sulfetos nas tubulações e 0 consequente desprendimento de odor. 


\section{FIGURA 3.1 - Geração de sulfetos e despreendimento de odor}

Efeitos:

- Corrosão da tubulação

- Odor desagradável

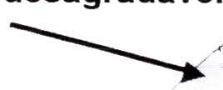

$$
\mathrm{H}_{2} \mathrm{~S}+2 \mathrm{O}_{2}=\mathrm{H}_{2} \mathrm{SO}_{4}
$$

(por ação bacteriológica)

Umidade

nas

$\mathrm{O}_{2} \mathrm{~S}$ estará presente se a geração de

Paredes sulfetos exceder a transferência de $\mathrm{O}_{2}$

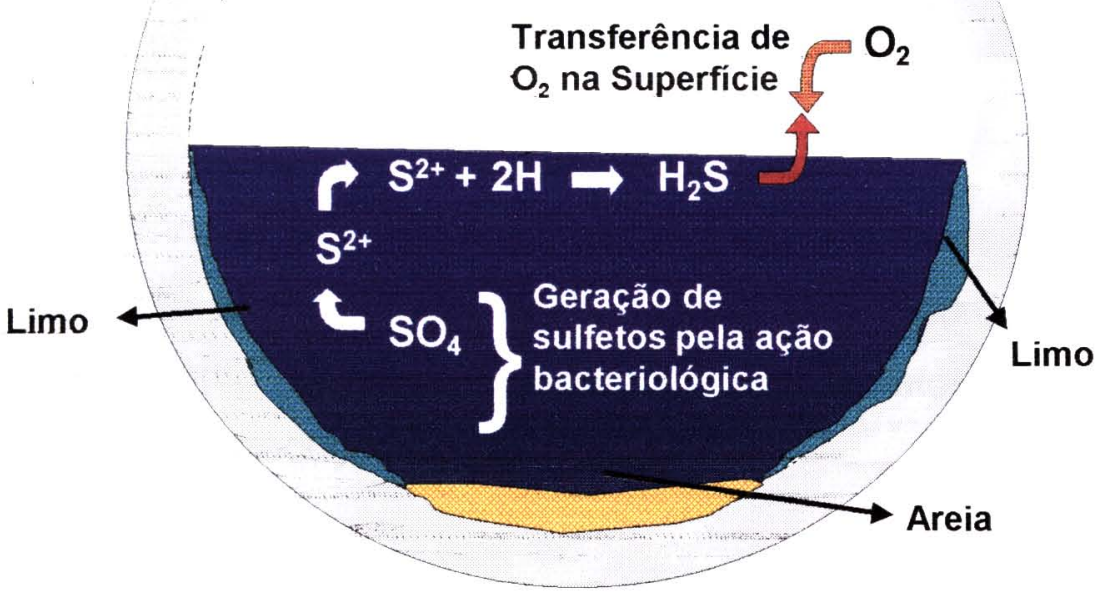

Fonte: JORDÃO \& PESSÔA, 1995.

A produção de $\mathrm{H}_{2} \mathrm{~S}$ nos esgotos aumenta com a temperatura, com as condições de septicidade, com a queda do $\mathrm{pH}$ e da velocidade de escoamento (PESSÔA \& JORDÃO, 1995).

\subsubsection{Odor em Estações de Tratamento de Esgotos}

A produção de odor em estações de tratamento de esgotos encontrase relacionada, principalmente, à presença de sulfeto nos esgotos (MORITA, 1996). 
O principal causador do mau cheiro é o gás sulfídrico, $\mathrm{H}_{2} \mathrm{~S}$, cuja presença desagradável pode ser notada pelo sentido do olfato em concentrações acima de 1 ppm (JORDÃO \& PESSÔA, 1995).

Os odores nas estações são gerados por misturas complexas de moléculas químicas com enxofre $\left(\mathrm{H}_{2} \mathrm{~S}\right.$, mercaptanas), nitrogênio $\left(\mathrm{NH}_{3}\right.$ e aminas), fenóis, aldeidos, cetonas, álcoois e ácidos orgânicos.

As substâncias responsáveis pela geração de odores são resultantes da decomposição anaeróbia de matéria orgânica contendo, principalmente, enxofre e nitrogênio. Destaca-se a ređução de sulfatos produzindo gás sulfidrico $\left(\mathrm{H}_{2} \mathrm{~S}\right)$ e a produção de amônia $\left(\mathrm{NH}_{3}\right)$.

Os compostos com enxofre podem ser tóxicos e irritantes para os olhos e vias respiratórias, mesmo em baixas concentrações (BELLI FILHO et al. 2001a)

No QUADRO 3.2 são apresentadas as características dos principais compostos relacionados aos odores ofensivos em ETEs. Observa-se que os compostos com enxofre possuem limites de detecção e percepção olfativos com reduzidas concentraçōes, sendo, portanto, os principais compostos responsáveis pelos odores. Em segundo grau de importância apresentam-se os compostos com nitrogênio. 
QUADRO 3.2 - Características dos principais compostos odorantes em estações de tratamento de esgotos

\begin{tabular}{|c|c|c|c|c|c|}
\hline $\begin{array}{l}\text { Classe de } \\
\text { composto }\end{array}$ & Composto & $\begin{array}{c}\text { Peso } \\
\text { molecular }(\mathrm{g})\end{array}$ & $\begin{array}{l}\text { Fórmula } \\
\text { química }\end{array}$ & $\begin{array}{c}\text { Característica dos } \\
\text { odores }\end{array}$ & $\begin{array}{l}\text { Limite olfativo } \\
\text { (mg/ } / \mathrm{Nm}^{3} \text { ar) }\end{array}$ \\
\hline \multirow[t]{6}{*}{ Enxofre } & Ácido Sulfidrico & 34,10 & $\mathrm{H}_{2} \mathrm{~S}$ & Ovo podre & 0,0001 a 0,03 \\
\hline & Metilmercaptana & 48.10 & $\mathrm{CH}_{3} \mathrm{SH}$ & Repolho, alho & 0.0005 a 0.08 \\
\hline & Etilmercaptana & 62,10 & $\mathrm{C}_{2} \mathrm{H}_{5} \mathrm{SH}$ & Repolho deteriorado & 0,0001 a 0,03 \\
\hline & Dimetilsulfeto & 62.13 & $\left(\mathrm{CH}_{3}\right)_{2} \mathrm{~S}$ & Legumes deteriorados & 0,0025 a 0,65 \\
\hline & Dietilsulfeto & 90,20 & $\left(C_{2}+H_{5}\right)_{2} S$ & Etéreo & 0.0045 a 0.31 \\
\hline & Dimetildissulfeto & 94,20 & $\left(\mathrm{CH}_{3}\right)_{2} \mathrm{~S}_{2}$ & Pútrico & 0.003 a 0.0014 \\
\hline \multirow[t]{7}{*}{ Nitrogênio } & Amônia & 17,00 & $\mathrm{NH}_{3}$ & Picante e irritante & 0,5 a 37 \\
\hline & Metilamina & 31.05 & $\mathrm{CH}_{3} \mathrm{NH}_{2}$ & Peixe em decomp * & 0,0021 \\
\hline & Etilamina & 45.08 & $\mathrm{C}_{2} \mathrm{H}_{3} \mathrm{NH}_{2}$ & Picante, amoniacal & 0,05 a 0,83 \\
\hline & Dimetilamina & 45.08 & $\left(\mathrm{CH}_{3}\right)_{2} \mathrm{NH}$ & Peixe deteriorado & 0,047 a 0,16 \\
\hline & Indol & 117,50 & $\mathrm{C}_{8} \mathrm{H}_{6} \mathrm{NH}$ & Fecal, nauseante & 0,0006 \\
\hline & Escatol & 131,50 & $\mathrm{C}_{9} \mathrm{H}_{8} \mathrm{NH}$ & Fecal, nauseante & 0,0008 a 0,10 \\
\hline & Cadaverina & 102.18 & $\mathrm{NH}_{2}\left(\mathrm{CH}_{2}\right)_{5} \mathrm{NH}_{2}$ & Carne em decomp: & - \\
\hline \multirow[t]{3}{*}{ Ácidos } & Acético & 60,05 & $\mathrm{CH}_{3} \mathrm{COOH}$ & Vinagre & 0,025 a 6,5 \\
\hline & Butirico & 88,10 & $\mathrm{C}_{3} \mathrm{H}_{7} \mathrm{COOH}$ & Manteiga & 0,0004 a 3 \\
\hline & Valérico & 102.13 & $\mathrm{C}_{4} \mathrm{H}_{9} \mathrm{COOH}$ & Suor & 0.0008 a 1.3 \\
\hline \multirow{5}{*}{$\begin{array}{l}\text { Aldeidos e } \\
\text { Cetonas }\end{array}$} & Formaldeido & 30,03 & $\mathrm{HCHO}$ & Ocre, sufocante & 0.033 a 1.12 \\
\hline & Acetaldeido & 44.05 & $\mathrm{CH}_{3} \mathrm{CHO}$ & Maçã & 0.04 a 1.8 \\
\hline & Butiraldeido & 72,10 & $\mathrm{C}_{3} \mathrm{H}_{7} \mathrm{CHO}$ & Ranço & 0,013 a 15 \\
\hline & Isovaleraldeido & 86,13 & $\left(\mathrm{CH}_{3}\right)_{2} \mathrm{CHCH}_{2} \mathrm{C}$ & Fruta, maçã & 0.072 \\
\hline & Acetona & 58.08 & $\mathrm{HOCH}_{3} \mathrm{COCH}_{3}$ & Fruta doce & 1,1 a 240 \\
\hline \multirow{4}{*}{$\begin{array}{l}\text { Álcoóis e } \\
\text { Fenóis }\end{array}$} & Etanol & 46,00 & $\mathrm{CH}_{3} \mathrm{CH}_{2} \mathrm{OH}$ & - & 0.2 \\
\hline & Butanol & 74 & $\mathrm{C}_{3} \mathrm{H}_{7} \mathrm{CH}_{2} \mathrm{OH}$ & - & 0,006 a 0,13 \\
\hline & Fenol & 94 & $\mathrm{C}_{6} \mathrm{H}_{5} \mathrm{QH}$ & - & 0,0002 a 0,004 \\
\hline & Cresol & 108 & $\mathrm{C}_{6} \mathrm{H}_{4} \mathrm{CH}_{3} \mathrm{OH}$ & - & 0,00001 \\
\hline
\end{tabular}

Fonte: BELLI FILHO et al., $2001 \mathrm{a}$.

* decomp. $=$ decomposição 


\subsection{Repercussões Associadas aos Odores de ETEs}

Além do inconveniente problema do odor que acaba sendo dispersado pelos arredores e vizinhança da ETE, operadores não devidamente equipados estão sujeitos à toxidade aguda pela inalação de gás sulfídrico, principalmente em estações que utilizam processos anaeróbios de tratamento (PIVELI, 1998).

$\mathrm{O}$ gás sulfídrico $\left(\mathrm{H}_{2} \mathrm{~S}\right)$ é tóxico para os seres humanos, causando morte em 30 minutos quando em concentrações gasosas de 800 a 1000 ppm; sendo que concentrações maiores resultam em morte instantânea (SPEECE, 1996).

Para referenciar este importante aspecto relativo à saúde dos trabalhadores da ETE, tem-se o alarmante relato do CIT - Centro de Informações Toxicológica do Governo do Estado do Rio Grande do Sul: "Dois funcionários (J.E.R., 22 anos e A.V., 41 anos) de um curtume em Arroio do Meio - RS, no vale do Taquari, morreram após exposição a gases provenientes de um tanque de tratamento dos efluentes da empresa. Um terceiro funcionário, que também se encontrava no locat (G.S., 25 anos), foi atendido em hospital da região, em estado de intensa ansiedade e exalando forte odor semelhante à ovo podre, tendo permanecido em observação por 48 horas, com boa evolução" (CIT, 2002).

Assim sendo, a protiferação de odores ofensivos pode ser caracterizada como um impacto negativo do tratamento de esgotos sanitários, que repercute sobre as populações vizinhas e os operadores das ETEs no que tange ao seu bem estar e potencialmente sobre a sua saúde.

Outro aspecto importante a se considerar, diz respeito à indisposição que a proliferação de odores ofensivos causa às populações, no entorno da estação. Os dados apresentados na FIGURA 3.2 demostram com ctareza a tendência à rejeiçăo popular da ETE em decorrência deste impacto. 
FIGURA 3.2 - Percepção de impactos decorrentes da operação da ETE Parque Dona Esther, em Cosmópolis - SP, por parte da população vizinha compreendida pelo raio $(R)=500 \mathrm{~m}$, traçado ao redor da estação

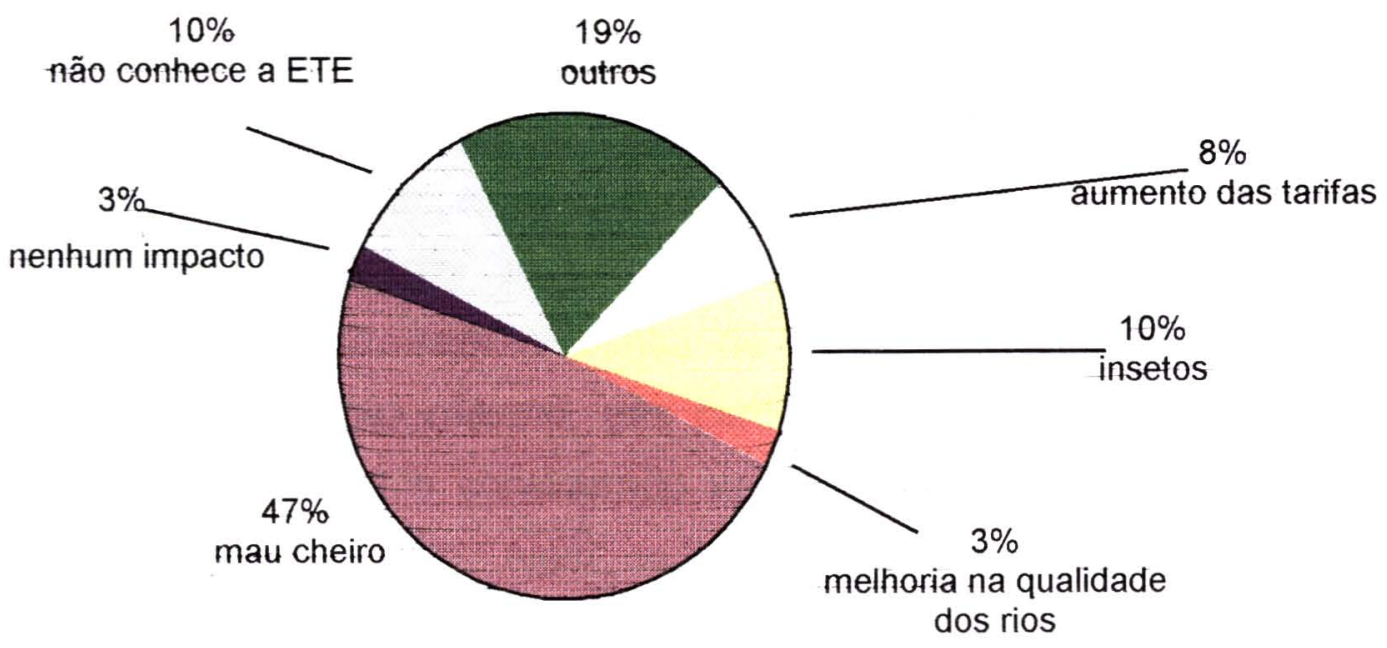

Fonte: DE SOUZA, 1998, adaptado.

Com um percentual de $47 \%$ dos entrevistados queixando-se do mau cheiro relacionado à estação de tratamento de esgotos (DE SOUZA, 1998), percebe-se a importância deste impacto como um fator agravante na relação usuários (aqui representados pelos moradores da vizinhança da ETE) e o órgão responsável pelo saneamento (no caso de Cosmópolis, o DAE Departamento de Água e Esgoto ligado à Prefeitura Municipal).

Outro caso interessante a ser citado, é o que envolve o Frigorífico da Swift Armour em Campo Grande, Mato Grosso do Sul. A população do bairro Jardim Carioca (vizinho ao frigorífico) moveu uma ação através da Defensoria Pública do Estado com o objetivo de paralisar o funcionamento de duas lagoas do sistema de tratamento de efluentes. O motivo refere-se ao cheiro insuportável que o sangue e as vísceras de animais abatidos causam na região. As quatro lagoas existentes no local, que deveriam purificar os detritos do frigorífico, não estão cumprindo sua função, segundo 
a Defensoria Pública. Para agravar ainda mais a situação, as duas primeiras lagoas já não podem funcionar. O processo é movido por 30 moradores do bairro e encontra-se em andamento.

Os problemas na saúde da população local também foram agregados ao processo. Segundo relatório da Defensoria, o forte odor do material em decomposição das lagoas "... vem causando problemas respiratórios, principalmente em crianças. Muitas delas já têm de passar por inalações e tratamentos respiratórios para tosses e bronquites". A decomposição anaeróbica, ou seja, sem presença do oxigênio, nos lagos, lagoas ou tanques, libera o gás metano, gás carbônico e o gás sulfídrico. $O$ gás sulfidrico é corrosivo e considerado venenoso e o metano pode causar explosão, se acumulado. Além de doenças respiratórias os moradores temem pela transmissão de outras enfermidades como diarréias, dores de cabeça e hepatite

A ação contra o Frigorifico Swift Armour baseia-se no artigo 554 do Código Civil. Ele estabelece que "o proprietário, ou inquilino de um prédio tem o direito de impedir que o mau uso da propriedade vizinha possa prejudicar a segurança, o sossego e a saúde dos que o habitam". "Eles estão agredindo o meio ambiente e acabando com a saúde de seus próprios vizinhos", acusa Getúlio Siqueira Santos, morador do Jardim Carioca (ECOA. 2002).

Também nos países ditos mais desenvolvidos, como os EUA por exemplo, o problema de maus odores decorrentes do tratamento de esgotos, tem indisposto as populações vizinhas contra as estações.

Em Salem, Massachusetts, durante os meses quentes de 1995 e coincidentemente durante a expansão do projeto da ETE "South Essex", a empresa de saneamento responsável recebeu uma série de reclamações referentes à proliferação de maus odores, por parte dos vizinhos da estação 
Contribuindo para o agravamento do problema, existiam na região várias indústrias com potencial para a produção de odores, além do fato de as condições geográficas serem desfavoráveis, dificultando assim traçar a fonte dos odores.

Em busca de soluções para o problema, a empresa responsável pela ETE "South Essex" convidou os vizinhos interessados para participarem de um programa de amostragem de odor, o qual incluía palestras e treinamento para a coletagem de amostras pela própria população, além de participação nas etapas de análise do material coletado e elaboração dos laudos técnicos.

Os resultados de todo este esforço conjunto foram mais do que favoráveis, não apenas pelos subsídios para a minimização do problema, mas também, e principalmente, pelo estreitamento da relação entre a empresa e os usuários (CRANE \& LANNAN, 1997).

Infelizmente, ainda são poucas as iniciativas desta ordem e a questão dos maus odores é algo com que muitas pessoas tem que lidar no seu cotidiano familiar, escolar ou de trabalho.

Há que se considerar ainda, que a proliferação de odores ofensivos do tratamento de esgotos sanitários, também pode vir a acarretar mudanças de hábitos nas populações atingidas, contribuindo para a degradação da qualidade de vida dos moradores e demais pessoas que se utilizam do espaço no entorno da ETE.

Tornou-se comum para muitas destas pessoas, o hábito de fechar portas e janelas na tentativa de se isolar dos maus odores; utilizar menos e nunca nos horários em que o cheiro é mais forte: varandas, jardins e quintais; fazer uso de desodorizadores de ambiente (produtos comerciais tais como o popular "Bom ar"); e desculpar-se a todo tempo com as visitas acerca do odor desagradável, justificando-o e explicando-o vezes e mais 
vezes, para não comprometer a imagem da higiene da moradia ou estabelecimento escolar ou de trabalho.

Devido à relevância deste aspecto de degradação da qualidade de vida, em virtude da proliferação de odores ofensivos do tratamento de esgotos sanitários, este assunto será tratado com mais propriedade quando da discussão dos resultados deste trabatho (capítuto 8).

\subsection{Controle de Odores em ETEs}

A emissão de odor por ETEs situadas em áreas urbanas tem se tornado um dos principais motivos de reclamações públicas. Na Europa, nos EUA e, principalmente, no Japão existem dificuldades para instalação das estações devido ao efeito NIMBY (capítulo 2).

O público parece menos inctinado com o passar do tempo a suportar a convivência com odores ofensivos. Desse modo, as empresas de saneamento passam a avaliar e reformular seus processos de tratamento para poderem alcançar niveis de emissão atmosférica desejados.

Uma área que tem despertado bastante atenção é o tratamento desses poluentes odorantes presentes no ar (BRAUER, 1986; LESON \& WINER, 1991)

Existem várias técnicas para tratamento de gases odorantes, tais como métodos físicos e quimicos como oxidação térmica, lavadores químicos, ozonização e adsorção por carvão ativado e métodos biológicos como biofiltração, biolavadores e lodos ativados.

Embora as técnicas físico e químicas possam remover com eficiência os compostos odorantes da corrente gasosa, dentro de certas condições, a necessidade de adição de produtos químicos diariamente e da substituição 
do adsorvente resulta em custo de operação relativamente alto quando comparado com técnicas de tratamento biológico.

Atualmente, dentre os processos de tratamento biológicos disponiveis para controlar odor destaca-se a biofittração. O biofiltro consiste de um tanque empacotado com material que pode ser terra, madeira, lodo de esgoto, turfa ou uma mistura desses materiais que servem de suporte para $\sigma$ crescimento de microrganismos. Esses microrganismos consomem os produtos químicos odorantes provenientes dos exaustores das ETEs, oxidando-os e, desse modo, eliminando o odor (ANDRADE et al., 2001).

O processo de biofiltração para eliminação de compostos odorantes mostra-se vantajoso em relação aos outros processos de tratamento biológicos, por apresentar as seguintes vantagens: facilidades na manutenção, operação imediata (adsorção), baixo consumo de água $e$ energia e, baixo custo operacional.

O biofiltro tem como desvantagem a sua colmatação e requer maior área para a sua implantação em comparação com os processos físicos e químicos de tratamento de gases. Porém, custa bem menos e não apresenta riscos de manipulação de produtos químicos perigosos (BELLI FILHO et at., 2000). 


\section{Aspectos Toxicológicos Relacionados ao Sulfeto}

\subsection{Importância do Sulfeto nos Esgotos}

$\dot{E}$ quase inevitável que se desprendam odores desagradáveis de uma estação de tratamento de esgotos, não importando qual seja o processo empregado. A maioria dos odores é ocasionada por uma sobrecarga de matéria orgânica ou pela operação inadequada do processo; e sua produção, relaciona-se, principalmente, com a presença de sulfeto nos esgotos (UEHARA, 1989; METCALF \& EDDY, 1985).

A presença de sulfeto em esgoto doméstico é devido em grande parte à ação biológica, que resulta da redução do sulfato. Em menor proporção, 0 sulfeto pode ser também gerado pela decomposição da matéria orgânica contendo enxofre - "proteinas albuminóides" (MORITA, 1996).

Outra fonte de sulfeto são os despejos industriais, como por exemplo, os curtumes, refinarias de petróleo, indústrias de celulose, etc. (BRAILE \& CAVALCANTI, 1993).

A presença de sulfeto nos esgotos pode acarretar os seguintes efeitos desagradáveis:

toxidade aguda aos operadores e possiveis repercussões sobre as populações vizinhas;

corrosão em estruturas, especialmente as de cimento (tubulações, por exemplo);

odores ofensivos; 
- intumescimento filamentoso dos lodos ativados podendo comprometer o tratamento;

- $\quad$ toxidade em sistemas de tratamento anaeróbios (inibição das bactérias anaeróbias).

Todas essas consequências potenciais devem ser previstas e controladas, para que o tratamento não seja comprometido e principalmente, não coloque em risco à saúde e o bem estar de operadores e populações vizinhas.

Devido à sua grande importância no âmbito da Saúde Pública e por se tratar também de um problema de Saúde Ocupacional, neste capitulo, serão estudados aspectos toxicológicos relacionados ao sulfeto.

\subsection{Principais Compostos de Enxofre Ligados ao Tratamento de Esgotos}

Os sulfetos presentes no esgoto, podem estar sob a forma de sais metálicos insolúveis ou dissolvidos, como $\mathrm{H}_{2} \mathrm{~S}$ ou $\mathrm{HS}^{-}$. As concentrações destes últimos são variáveis, dependendo do $\mathrm{pH}$, conforme mostra a seguinte reação:

$$
\mathrm{H}_{2} \mathrm{~S} \leftrightarrow \mathrm{HS}^{-}+\mathrm{H}^{+}
$$

A forma iônica $S^{2-}$ está presente em quantidade insignificante, sendo menor que $0,5 \%$ do sulfeto dissolvido em $\mathrm{pH}$ igual a 12,0 e menor do que $0.05 \%$ em pH 11 (MORITA, 1996).

O sulfeto de hidrogênio - $\mathrm{H}_{2} \mathrm{~S}$ - também conhecido por gás sulfidrico, é a forma mais encontrada nos esgotos. Trata-se de um gás tóxico, mais 
pesado que o ar (cerca de 1,19 vezes mais denso), incolor e inflamável, com odor caracteristico de "ovo podre" (CANELAS et al., 1998; DIAS et al., 2002; CIT, 2002)

$\mathrm{O}_{2} \mathrm{~S}$ é detectado pelo olfato humano mesmo em concentrações reduzidas, no entanto, graças à sua ação anestesiante pode passar despercebido quando em concentrações elevadas (CANELAS et al., 1998). Sua toxidade tem sido comparada à do ácido cianídrico (EPA, 1985), e sua inalação pelo homem, tem constituído a causa principal da ocorrência de acidentes fatais em sistemas de drenagem e tratamento de águas residuárias (DIAS et al., 2002).

O QUADRO 4.1 apresenta alguns dos efeitos que a exposição humana ao gás sulfidrico pode ocasionar.

QUADRO 4.1 - Efeitos produzidos pela exposição humana ao gás sulfidrico

\begin{tabular}{|c|c|c|}
\hline $\begin{array}{c}\text { Tempo e condições de } \\
\text { exposição }\end{array}$ & $\begin{array}{l}\text { Concentrações de H2S na } \\
\text { atmosfera do sistema de } \\
\text { esgotos ppm (em volume) }\end{array}$ & Efeitos \\
\hline $\begin{array}{c}\text { Exposição prolongada, trabalho } \\
\text { leve }\end{array}$ & 5-10 (algumas pessoas menos) & Pouco ou nenhum \\
\hline 1 a 2 horas, trabalho leve & $10-50$ (algumas pessoas menos) & $\begin{array}{l}\text { Irritações leves nos olhos e nas } \\
\text { vias respiratórias, dores de } \\
\text { cabeça. }\end{array}$ \\
\hline $\begin{array}{l}6 \text { horas de trabalho manual } \\
\text { pesado }\end{array}$ & Cerca de 50 & Cegueira temporária \\
\hline $\begin{array}{c}1 \text { hora de trabalho manual } \\
\text { pesado }\end{array}$ & Cerca de 100 & $\begin{array}{l}\text { Limite máximo, consequências } \\
\text { sérias }\end{array}$ \\
\hline
\end{tabular}

Fonte: ALÉM SOBRINHO \& TSUTIYA, 2000 apud BELLI FILHO et al., 2001a. 
Outro importante composto de enxofre que pode estar presente no tratamento de esgotos é o ácido sulfúrico $\left(\mathrm{H}_{2} \mathrm{SO}_{4}\right)$, que resulta da combinação do gás sulfídrico com oxigênio, por ação bacteriológica, conforme visto no capítulo 3, FIGURA 3.1. Apesar de estar mais ligado à corrosão de tubulações, o ácido sulfúrico pode, quando inalado, acarretar lesões e queimaduras nos olhos, pele e, se ingerido, no trato intestinal (PLUNKETT, 1987; KLAASSEN, 1996).

\subsection{Ação Tóxica e Limite de Tolerância do $\mathrm{H}_{2} \mathrm{~S}$}

A ação tóxica do gás sulfídrico deve-se à inibição do sistema citocromo-oxidase, que resulta em hipóxia intracelular e acidose metabólica.

Produz um efeito irritativo local, ao combinar-se com átcalis presentes na superfície úmida das mucosas, formando sulfeto de sódio, um agente cáustico.

Quando em concentrações muito elevadas, como na faixa de $800-$ 2000 ppm, causa asfixia por apnéia secundária à depressão do centro respiratório, resultando em morte imediata.

O sulfeto de hidrogênio é um dos mais frequentes causadores de morte súbita no ambiente de trabalho, por exposição ocupacional.

Conforme Portaria 3214/78, Norma Regulamentadora NR-15, Anexo 11 , o limite de tolerância à exposição corresponde a $8 \mathrm{ppm}$ ou $12 \mathrm{mg} / \mathrm{m}^{3}$. (CIT, 2002) 


\subsection{Sintomatologia Relacionada à Intoxicação por $\mathrm{H}_{2} \mathrm{~S}$}

Efeitos irritativos em vias aéreas, dermatite dolorosa, ceratoconjuntivite e blefaroespasmo podem ocorrer mesmo em baixas concentrações. Pneumonite química e edema pulmonar não-cardiogênico podem ocorrer ao longo de horas. Efeitos sistêmicos agudos incluem cefaléia, náusea, vômito, confusão, tontura, convulsão e coma. Exposição a elevadas concentrações pode causar colapso cardiovascular imediato, parada respiratória e morte. Sobreviventes podem apresentar seqüelas neurológicas graves (CIT, 2002).

O gás sulfidrico paralisa o aparelho respiratório central e em altas concentrações também os nervos olfatórios, anulando a sensação do cheiro de "ovo podre" e a partir dai o perigo decorrente da exposição torna-se maior (SPEECE, 1996).

\subsection{Primeiros Socorros e Tratamento}

Contato com os olhos: lavá-los imediatamente com água; persistindo os sintomas. manter o paciente em local escuro e aplicar compressas frias.

Contato com a pele: remover roupas e lavar a pele com água.

Inalação: remover a pessoa para local ventilado. O socorrista deve possuir respirador autônomo. Administrar $\mathrm{O}_{2}$ umidificado, em alto fluxo. Tratamento de suporte para pneumonite, edema pulmonar, coma, convulsão ou hipotensão. Teoricamente, a administração de nitritos produz metahemoglobinemia que converte o ion sulfito a sulfemoglobina, que é 
menos tóxico, poupando o sistema citocromo-oxidase. Todavia, há pouca evidência da efetividade dos nitritos e podem causar hipotensão e prejudicar o transporte de $\mathrm{O}_{2}$ (CIT, 2002).

\subsection{Prevenção de Acidentes no Ambiente de Trabalho}

Deve-se enfatizar o treinamento dos funcionários sobre os riscos envolvidos, técnicas de manuseio seguro e procedimentos de emergência. Distribuir cartazes com advertência: "pode ser fatat se inalado". Não fumar, comer ou beber onde se manuseia com o produto.

Quando possivel, manter o ambiente com ventilação exaustora adequada nos pontos de emissão de vapores. Quando for necessário entrar em local confinado que possa conter $\mathrm{H}_{2} \mathrm{~S}$, o espaço deve ser purgado e a concentração determinada, antes de qualquer operação e, também, em intervalos regulares durante a jornada de trabalho.

Atenção para fontes de ignição e de calor, produtos fortemente oxidantes, liquidos e gases corrosivos. Tratamento de residuos com cloro e hipoclorito de cálcio, para prevenir acúmulo de $\mathrm{H}_{2} \mathrm{~S}$ no esgoto, oxidando-o a $\mathrm{SO}_{4}^{-2}$. Pode-se utilizar $\mathrm{H}_{2} \mathrm{O}_{2}$.

EPI (Equipamento de Proteção Individual) recomendado: luvas de borracha e óculos de segurança, se trabalhar com líquidos. Respirador com filtro químico para curta exposição e respirador autônomo, se a concentração do gás apresentar-se acima do limite de tolerância (CIT, 2002).

Nem todas estas recomendações para a prevenção de acidentes envolvendo gás sulfídrico $\left(\mathrm{H}_{2} \mathrm{~S}\right)$ são aplicáveis à sistemas de tratamento de 
esgotos (como a aplicação de cloro, por exemplo, que pode comprometer os reatores biológicos).

Todavia, o treinamento adequado e a conscientização dos operadores acerca do risco existente e da importância do uso de equipamentos de proteção individual, devem ser constante e exaustivamente estimulados. 


\section{Objeto de Estudo de Caso: ETE - Piracicamirim - Piracicaba - SP}

Este capitulo visa apresentar a ETE (FIGURA 5.1) que constituiu-se em objeto de estudo de caso para este trabalho e os motivos que levaram à escotha da mesma. Para tanto, serão apresentados os aspectos que se consideraram relevantes nesta eleição, tais como: região onde se localiza a estação, órgão de saneamento responsável, dados de projeto, entre outros.

FIGURA 5.1 - ETE - Piracicamirim

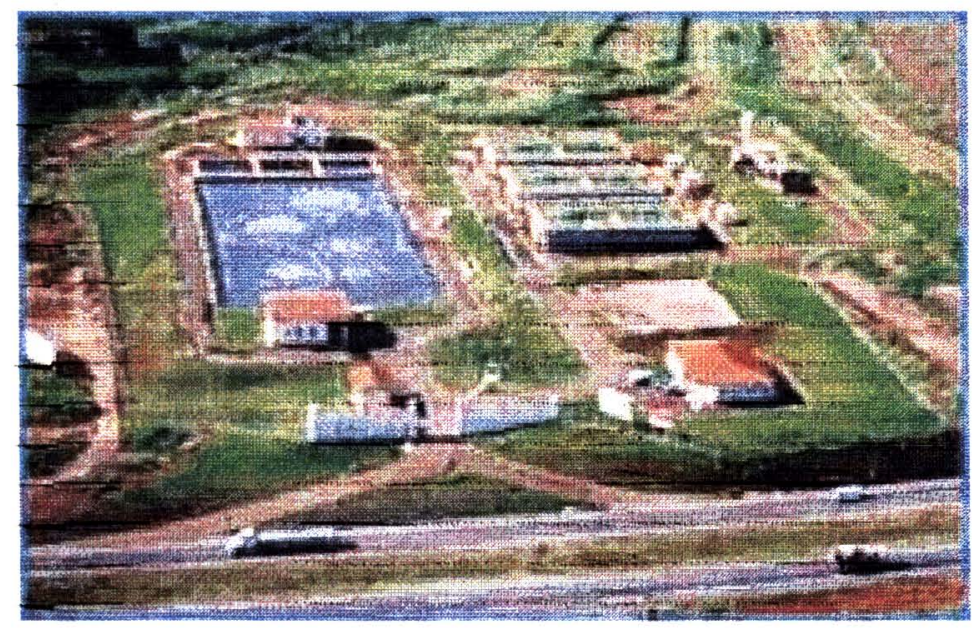

Fonte: SEMAE, 2002.

\subsection{Localização: A Região da Bacia do Rio Piracicaba}

A bacia hidrográfica é uma unidade natural que corresponde à extensão de terras onde todas as águas de chuva e dos rios correm em direção ao rio principal. Este rio principal é que dá o nome a uma bacia hidrográfica (MONTICELI \& MARTINS, 1993).

O rio Piracicaba nasce na cidade de Americana, no encontro das águas do rio Atibaia com o Jaguari (FIGURA 5.2). 
FIGURA 5.2 - Formação do Rio Piracicaba em Americana-SP. À esquerda Rio Atibaia e à direita Rio Jaguari; no centro o Rio Piracicaba

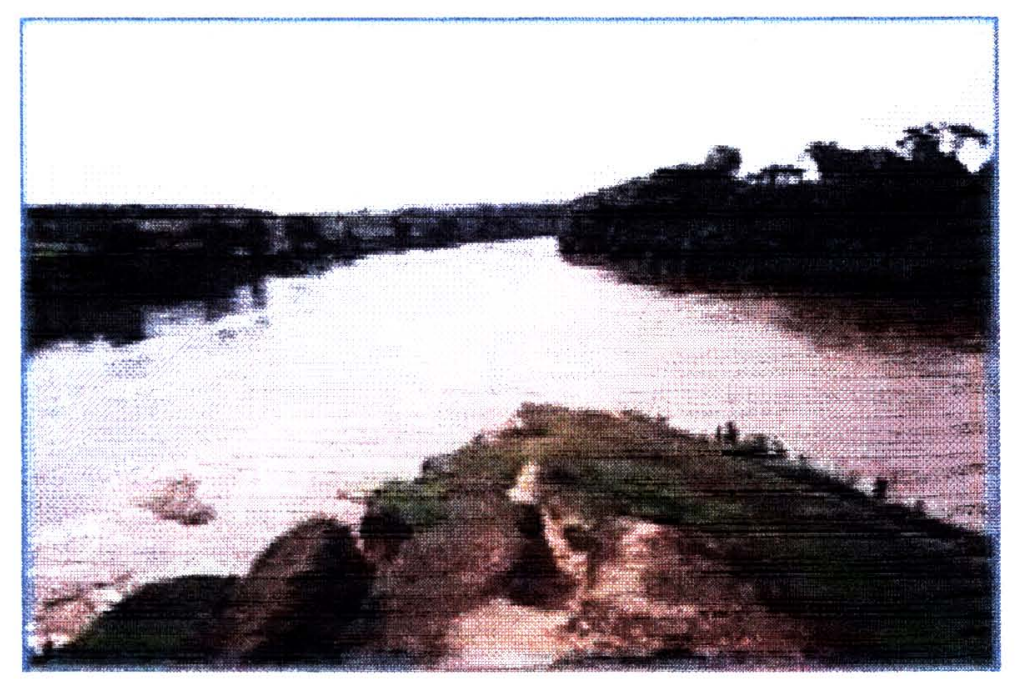

Fonte: SEMAE, 2002

As nascentes do rio Jaguari localizam-se no Estado de Minas Gerais, em Camanducaia. A formação do rio Atibaia ocorre na junção dos rios Atibainha e Cachoeira. O Atibainha nasce nas proximidades de Nazaré Paulista e o Cachoeira, na região de Piracicaba.

O Piracicaba tem outros afluentes importantes como: Quilombo quenasce em Campinas, Toledo que nasce na região de Santa Bárbara D'Oeste, Corumbataí que nasce em Analândia, ribeirão Anhumas que nasce em Campinas, ribeirão Piracicamirim que nasce na região de Piracicaba, ribeirão Pinheiros que nasce na região de Vinhedo, entre outros (SEMAE, 2002).

De acordo com os critérios estabelecidos pela legislação federat, $\theta$ Piracicaba é um rio de Classe 2, entretanto em alguns trechos passa a ser considerado como Classe 4 - pior classificação possível para águas doces, 0 que corresponde também ao trecho em que atravessa a cidade de mesmo nome. Já o ribeirão Piracicamirim é um corpo receptor de Classe 2. 
A Bacia do Rio Piracicaba possui uma superficie de $12.746 \mathrm{~km}^{2}$. Quanto ao clima da região, quase a totalidade da área da bacia é de clima subtropical, com temperaturas médias anuais entre $18^{\circ} \mathrm{C}$ e $22^{\circ} \mathrm{C}$. Apenas $2 \%$ dos municipios possuem clima temperado, com temperaturas médias anuais entre $12^{\circ} \mathrm{C}$ e $18^{\circ} \mathrm{C}$ (SIGRH, 2002).

A região abrange total ou parcialmente cerca de 50 municípios e engloba o mais importante núcleo industrial depois da Grande São Paulo, que é a região de Campinas e 0 eixo rodoviário Anhanguera (SEBASTIANES, 1992).

A FIGURA 5.3 apresenta a localização da Bacia do Rio Piracicaba em relação ao Estado de São Paulo

FIGURA 5.3 - Bacia do Rio Piracicaba: Localização em Relação ao Estado de SP.

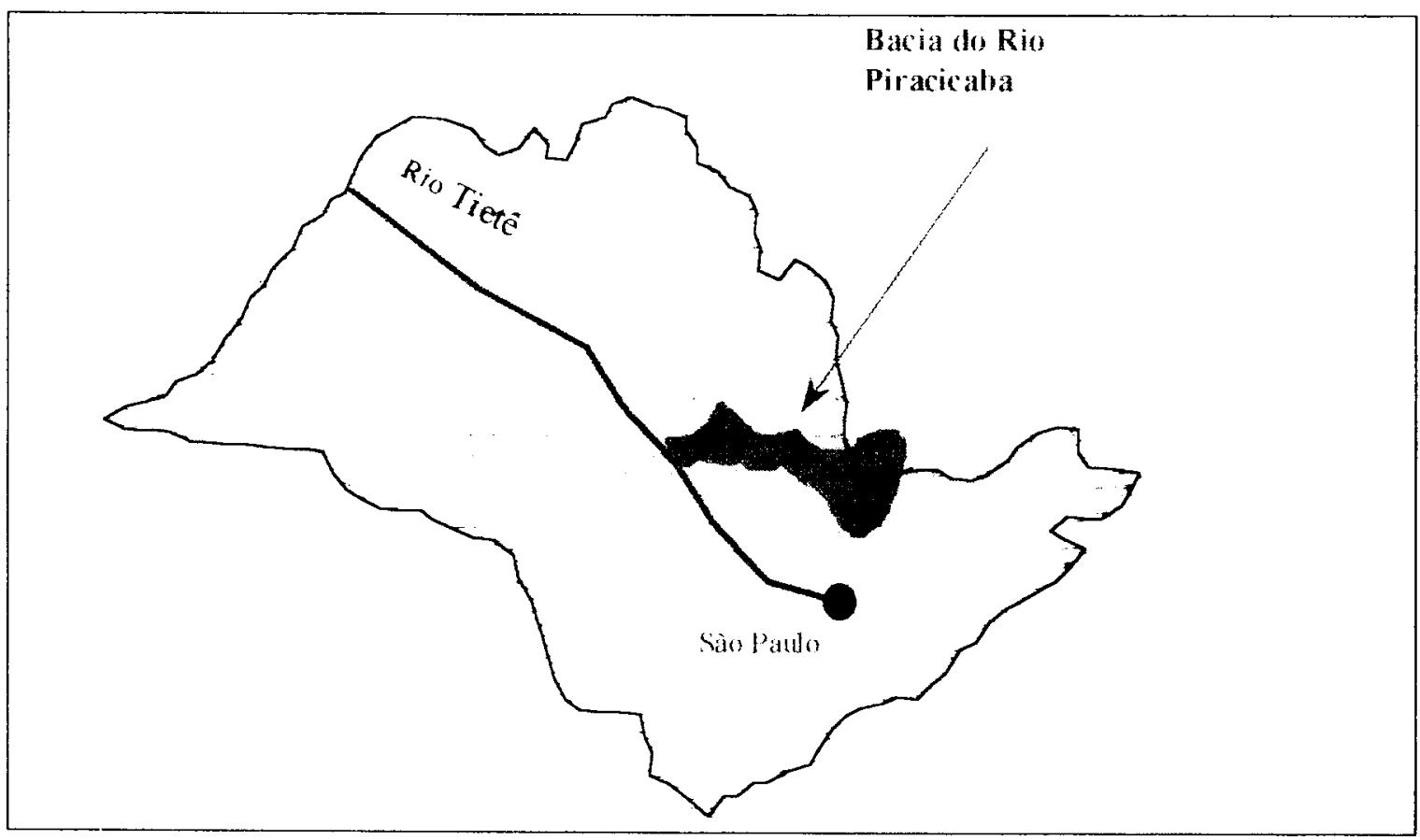

Fonte: CBH-PCJ, 1996.

Os municipios que compõem a Bacia do Rio Piracicaba são os seguintes: 
Estado de São Paulo - Águas de S. Pedro, Americana, Analândia, Artur Nogueira, Atibaia, Bom Jesus dos Perdões, Bragança Paulista, Campinas, Charqueada, Cordeirópolis, Corumbataí, Cosmópolis, Holambra, Hortolândia, Ipeúna, Iracemápolis, Itatiba, Jaguariúna, Jarinú, Joanópolis, Limeira, Monte Alegre do Sul, Morungaba, Nazaré Pautista, Nova Odessa, Paulinia, Pedra Bela, Pedreira, Pinhalzinho, Piracaia, Piracicaba, Rio Claro, Rio das Pedras, Saltinho, Santa Bárbara D'Oeste, Santa Gertrudes, Santa Maria da Serra, Santo Antonio da Posse, São Pedro, Sumaré, Tuiuti, Valinhos, Vargem e Vinhedo.

Estado de Minas Gerais - Camanducaia, Extrema, Itapeva e Toledo (ANEXO 4).

\subsubsection{Importância Econômica e Social}

A Bacia do Rio Piracicaba localiza-se numa das regiões de maior crescimento econômico do país. Esse crescimento, fruto da potítica de desenvolvimento da década de 70 , deu origem a diversos problemas antes só encontrados na Região Metropolitana de São Paulo (RMSP). Tais problemas começaram a surgir, à medida em que alguns municípios da bacia passaram a constituir pólos de atração de diversas atividades altamente consumidoras e degradadoras do meio ambiente e dos recursos hidricos, em particular.

A partir de 1970, iniciou-se um intenso processo de interiorização do desenvolvimento, com o consequente crescimento das cidades da região da Bacia do Rio Piracicaba. Enquanto a Grande São Paulo e outras regiões do país cresciam, em população, a taxas de até $3,5 \%$ ao ano, na Bacia do Piracicaba essa taxa chegou a 5,1\% ao ano.

A evolução populacional dos municípios da Bacia do Piracicaba durante as décadas de 50 a 80 é apresentada no QUADRO 5.1. 
No QUADRO 5.2, apresentam-se as áreas totais dos municipios, a porcentagem de cada um deles sobre a área total da bacia, a população por município e o cálculo da densidade demográfica para os municípios da Bacia do Piracicaba nos anos 80 , conforme informações obtidas pelo IBGE no Censo de 1980.

\section{QUADRO 5.1 - Evolução populacional nos municípios da Bacia do Rio}

Piracicaba de 1960 a 2000

\begin{tabular}{|c|c|c|c|c|c|c|c|c|}
\hline MUNICIPIOS & \multicolumn{2}{|c|}{1960} & \multicolumn{2}{|c|}{1970} & \multicolumn{2}{|l|}{1980} & \multicolumn{2}{|l|}{2000} \\
\hline DA BACIA & 1 & 2 & 1 & 2 & 1 & 2 & 1 & 2 \\
\hline Aguas de S.Pedro & 585 & 0.06 & 830 & 0,06 & 1.058 & 0,05 & 1.839 & 5,76 \\
\hline Americana & 37.856 & 4,51 & 66.316 & 5.46 & 122.055 & 6.09 & 178.895 & 5.60 \\
\hline Amparo & 28636 & 3.41 & 31.908 & 2.62 & 41.594 & 2,07 & 59.267 & 1,86 \\
\hline Analândia & 2.870 & 0.34 & 2.612 & 0,21 & 2.301 & 0,11 & 3.504 & 0.11 \\
\hline Artur Nagueira & 8.210 & 0,97 & 10171 & 0,83 & 15.929 & 0,79 & 31.313 & 0,98 \\
\hline Atibara & 23.380 & 2.79 & 36.838 & 3.03 & 57.783 & 2,88 & 107.925 & 3,38 \\
\hline B J. dos Perdões & 2.605 & 0,31 & 3.837 & 0,31 & 7.113 & 0.35 & 12.800 & 0,40 \\
\hline Braganca Paulista & 56.124 & 6.69 & $\widetilde{63.676}$ & 5.24 & 83903 & 4,19 & 121.758 & 3,81 \\
\hline Campinas & 213.558 & 25,48 & 375.864 & 30,96 & 663.497 & 33.15 & 952.758 & 29.85 \\
\hline Charqueada & 6.801 & 0,81 & 7.924 & 0.65 & 8.896 & 0.44 & $\uparrow 2.740$ & 0,40 \\
\hline Cordeirópolis & 7.637 & 0,91 & 7.970 & 0.65 & 9.491 & 0,47 & 17.010 & 0,53 \\
\hline Corumbatai & 3.514 & 0,41 & 2.842 & 0,23 & 2.795 & 0.13 & 3.078 & 0,10 \\
\hline Cosmópotis & 8.798 & 1.05 & 12.115 & 0,99 & 23.205 & 1.15 & 43.109 & 1,35 \\
\hline Ipeúna & 2159 & 0,25 & 2.097 & 0,17 & 1.849 & 0,09 & 4.116 & 0,13 \\
\hline Facenopólis & 5836 & 0,69 & 6907 & 0,56 & 8.281 & 0,41 & 15.078 & 0.47 \\
\hline Itatiba & 20.892 & 2,49 & 28.376 & 2,33 & 41.650 & 2,08 & 78.471 & 2,46 \\
\hline Jaguariúna & 8.545 & 1,01 & 10.391 & 0,85 & 15.197 & 0,75 & 28.643 & 0,90 \\
\hline Jarinú & 4.391 & 0.52 & 5.143 & 0.42 & 6.202 & 0,30 & 16.820 & 0.53 \\
\hline Joanópolis & 8.844 & 1.05 & 7.362 & 0.60 & 7.753 & 0,38 & 10.112 & 0.32 \\
\hline Limeira & 60.719 & 7,24 & 90.953 & 7.49 & 150.574 & 7,52 & 243.531 & 7.63 \\
\hline Mte Alegre do Sul & 4.807 & 0,57 & 4.762 & 0,39 & 4.864 & 0,24 & 6.221 & 0,19 \\
\hline Morungaba & 3.108 & 0,37 & 5.032 & 0,41 & 6.516 & 0,32 & 9.717 & 0,30 \\
\hline Nazaré Paulista & 7.572 & 0,90 & 10.009 & 0.82 & 8.414 & 0.42 & 14.030 & 0,44 \\
\hline Nova Odessa & 5.710 & 0.68 & 8.336 & 0,68 & 21.871 & 1,09 & 41.035 & 1.29 \\
\hline Paulinia & 5.745 & 0,68 & 10.708 & 0,88 & 20.749 & 1,03 & 49.361 & 1.55 \\
\hline Pedra Bela & 7.392 & 0,88 & 5.230 & 0,43 & 4.703 & 0,23 & 5.562 & 0.17 \\
\hline Pedreira & 10.976 & 1,30 & 15.053 & 1,24 & 21.394 & 1,06 & 34.271 & 1,07 \\
\hline Pinhalzinho & 5.636 & 0,67 & 4.912 & 0,40 & 6.403 & 0,31 & 10.655 & 0,33 \\
\hline Pifacaia & 12.200 & 1,45 & 12.883 & 1.06 & 13.725 & 0.68 & 22.501 & 0,70 \\
\hline Piracicaba & 116.190 & 13,86 & 152.505 & 12,56 & 214.015 & 10,69 & 322.014 & 10,09 \\
\hline Rio Claro & 55.465 & 6.61 & 78.040 & 6.42 & 110.273 & 5.50 & 164.298 & 5,15 \\
\hline Rio das Pedras & 9.121 & 1.08 & 8.917 & 0.73 & 13.467 & 0.67 & 22.265 & 0,70 \\
\hline S. Barb. D'Oeste & 22.625 & 2,70 & 31.018 & 2,55 & 76.630 & 3,82 & 166.858 & 5,23 \\
\hline Santa Gertrudes & 5.130 & 0,61 & 6.010 & 0.49 & 7.993 & 0,39 & 15.179 & 0,48 \\
\hline S. Maria da Serra & 2.232 & 0.26 & 2147 & 0,17 & 2825 & 0.14 & 4.558 & 0.14 \\
\hline S. Ant. da Posse & 5.710 & 0,68 & 7.799 & 0,64 & 10.862 & 0,54 & 17569 & 0.55 \\
\hline São Pedro & 9.446 & 1.12 & 10.141 & 0,83 & 13.160 & 0.65 & 26.884 & 0,84 \\
\hline Sumaré & 10.663 & 1,27 & 23.074 & 1,90 & 101.872 & 5.08 & 189.052 & 5,92 \\
\hline Valinhos & 18.302 & 2.18 & 30.775 & 2,53 & 48.953 & 2,44 & 80.904 & 2.53 \\
\hline Vinhedo & 7.904 & 0,94 & 12.338 & 1,01 & 21.627 & 1.08 & 45.370 & 1.42 \\
\hline TOTAL da Bacia & 837.894 & 100 & 1.213 .831 & 100 & 2.001 .442 & 100 & 3.191 .701 & 100 \\
\hline TOTAL Estado & 12.974699 & - & 17.771948 & - & 25.023 .306 & - & 36.909 .200 & - \\
\hline
\end{tabular}

FONTE: $\quad$ PROCHNOW, 1981 atualizado a partir de SEADE, 2002.

Obs: 1. Números absotutos (habitantes)

2. \% sobre o total da Bacia do Piracicaba 
QUADRO 5.2 - Área Total e densidade demográfica dos municípios da Bacia do Rio Piracicaba a partir de informações do Censo Demográfico de 2000

\begin{tabular}{|c|c|c|c|c|}
\hline $\begin{array}{c}\text { Municipio da } \\
\text { Bacia do } \\
\text { Piracicaba }\end{array}$ & $\begin{array}{l}\text { Area Total do } \\
\text { Municipio } \\
\left(\mathrm{Km}^{2}\right)\end{array}$ & $\begin{array}{c}\text { Área do } \\
\text { Municipio em } \\
\% \text { na Bacia }\end{array}$ & $\begin{array}{c}\text { População do } \\
\text { Município } \\
\text { (hab) }\end{array}$ & $\begin{array}{l}\text { Densidade } \\
\text { Demográfic } \\
\text { a }\left(\text { hab/Km } m^{2}\right)\end{array}$ \\
\hline Águas de São Pedro & 8 & 0,07 & 1.839 & 230 \\
\hline Americana & 122 & 1,04 & 178.895 & 1466 \\
\hline Amparo & 442 & 3,77 & 59.267 & 134 \\
\hline Analândia & 313 & 2,67 & 3.504 & 11 \\
\hline Artur Nogueira & 340 & 2,90 & 31.313 & 92 \\
\hline Atibaia & 491 & 4,19 & 107.925 & 220 \\
\hline Bom Jesus dos Perdōes & 94 & 0,80 & 12.800 & 136 \\
\hline Bragança Paulista & 770 & 6,58 & 121.758 & 158 \\
\hline Campinas & 781 & 6,67 & 952.758 & 1220 \\
\hline Charqueada & 196 & 1,67 & 12.740 & 65 \\
\hline Cordeirópolis & 162 & 1,38 & 17.010 & 105 \\
\hline Corumbataí & 297 & 2,54 & 3.078 & 10 \\
\hline Cosmópolis & 201 & 1,72 & 43.109 & 214 \\
\hline Ipeúna & 207 & 1,77 & 4.116 & 20 \\
\hline Ifacenopólis & 91 & 0,78 & 15078 & 166 \\
\hline Itatiba & 295 & 2,52 & 78.471 & 266 \\
\hline Jaguariúna & 148 & 1,26 & 28.643 & 193 \\
\hline Jarinú & 204 & 1,74 & 16820 & 82 \\
\hline Joanópolis & 343 & 2,93 & 10.112 & 29 \\
\hline Limeira & 597 & 5,10 & 243.531 & 408 \\
\hline Monte Alegre do Sul & 137 & 1,17 & 6.221 & 45 \\
\hline Morungaba & 121 & 1,03 & 9.717 & 80 \\
\hline Nazaré Paulista & 325 & 2,78 & 14.030 & 43 \\
\hline Nova Odessa & 66 & 0,56 & 41.035 & 622 \\
\hline Paulinia & 145 & 1,24 & 49.361 & 340 \\
\hline Pedra Bela & 140 & 1,20 & 5.562 & 40 \\
\hline Pedreira & 114 & 0,97 & 34.271 & 301 \\
\hline Pinhalzinho & 161 & 1,38 & 10.655 & 66 \\
\hline Piracaia & 410 & 3,50 & 22.501 & 55 \\
\hline Piracicaba & 1.426 & 12,18 & 322.014 & 226 \\
\hline Rio Claro & 503 & 4,30 & 164.298 & 327 \\
\hline Rio das Pedras & 225 & 9,92 & 22.265 & 99 \\
\hline Santa Bárbara D'Oeste & 282 & 2,41 & 166.858 & 592 \\
\hline Santa Gertrudes & 92 & 0,79 & 15.179 & 165 \\
\hline Santa Maria da Serra & 269 & 2,30 & 4.558 & 17 \\
\hline Santo Antonio da Posse & 167 & 1,43 & 17.569 & 105 \\
\hline São Pedro & 587 & 5,01 & 26.884 & 46 \\
\hline Sumaré & 208 & 1,78 & 189.052 & 909 \\
\hline Valinhos & 144 & 1,23 & 80.904 & 562 \\
\hline Vinhedo & 85 & 0,72 & 45.370 & 534 \\
\hline TOTAL & 11.709 & 100 & 3.191 .701 & 273 \\
\hline
\end{tabular}

Fonte: DE SOUZA, 1998 atualizado a partif de SEADE, 2002.

Mesmo com a crise econômica iniciada na década de 80 , a industrialização, a urbanização e a modernização da agricultura nos municipios economicamente mais fortes da bacia, mantiveram indices superior à média do Estado (SMA, 1994). 
Em 1991, a taxa de urbanização chegou a $85 \%$, ou seja, de 100 habitantes, 85 estavam nas cidades e apenas 15 no campo. Como as bacias do Piracicaba e do Capivari (bacia vizinha) possuem juntas cerca de três milhões de habitantes, isso significa 2,55 milhões de pessoas nas cidades.

O crescimento urbano, associado ao processo de desenvolvimento social e agrícola, permitiu a aglomeração contínua das cidades de Campinas, Monte Mor, Indaiatuba, Valinhos, Louveira, Vinhedo, Nova Odessa, Hortolândia, Sumaré, Paulinia, Americana e Santa Bárbara D'Oste. Essa aglomeração de cidades é conhecida como Conurbação Campineira (MONTICELI \& MARTINS, 1993).

O QUADRO 5.3 apresenta projeções das taxas populacionais para os grupos de cidades (conurbadas, médias e de pequeno porte) da região das bacias vizinhas do Piracicaba e Capivari para os anos de 1990 a 2010.

QUADRO 5.3 - População total por grupo de cidades

\begin{tabular}{|l|r|r|r|r|r|r|r|r|}
\hline \multicolumn{1}{|c|}{$\begin{array}{l}\text { Grupos } \\
\text { Habitantes }\end{array}$} & \multicolumn{7}{|c|}{ População (habitantes) } \\
\cline { 2 - 9 } & 1990 & $\%$ & 1995 & $\%$ & 2000 & $\%$ & 2010 & $\%$ \\
\hline $\begin{array}{l}\text { 1) Cidades } \\
\text { Conurbadas }\end{array}$ & 1.626 .282 & 55 & 1.879 .999 & 56 & 2.166 .961 & 57 & 2.810 .739 & 59 \\
\hline $\begin{array}{l}\text { 2) Cidades Médias - 50 } \\
\text { a 300 mil }\end{array}$ & 855.331 & 29 & 944.404 & 28 & 1.039 .047 & 27 & 1.218 .222 & 26 \\
\hline $\begin{array}{l}\text { 3) Pequeno Porte - } \\
\text { menos de 50 mil }\end{array}$ & 484.844 & 16 & 539.902 & 16 & 590.809 & 16 & 697.457 & 15 \\
\hline Total & $\mathbf{2 . 9 6 3 . 4 6 7}$ & $\mathbf{1 0 0}$ & $\mathbf{3 . 3 6 4 . 3 0 5}$ & $\mathbf{1 0 0}$ & $\mathbf{3 . 7 9 6 . 5 4 7}$ & $\mathbf{1 0 0}$ & $\mathbf{4 . 7 2 6 . 4 1 8}$ & $\mathbf{1 0 0}$ \\
\hline
\end{tabular}

Fonte: Relatório do Consórcio Piracicaba-Capivani apud MONTICELI \& MARTINS, 1993.

* Louveira, Vinhedo, Valinhos, Campinas, Indaiatuba, Monte Mor, Sumaré, Hortolândia, Nova Odessa. Americana, Sta. Bárbara D'Oeste e Paulínia.

Este acelerado processo de urbanização da região da Bacia do Piracicaba, foi grandemente estimulado pelos elevados investimentos públicos de infraestrutura viária realizados nos últimos 30 anos, dos quais destacam-se principatmente: a construção da Rodovia Bandeirantes nos anos 70, ligando Campinas à São Paulo numa extensão de $100 \mathrm{Km}$; as duplicações nos anos 80 da Rodovia Piracicaba-Americana; da Rodovia 
Campinas-Sorocaba e Rodovia D. Pedro I, ligando a Via Anhanguera à Via Dutra; para citar apenas os mais importantes.

Também nos últimos 30 anos, intensificou-se o processo de desconcentração das atividades econômicas do Estado de São Paulo, com importantes modificações espaciais - indústrias transferindo-se da RMSP para o interior do Estado - processo esse denominado de interiorização do desenvolvimento econômico no Estado de São Paulo, ou como é mais comumente conhecido, processo de interiorização paulista (NEGRI, 1992).

O reflexo do dinamismo econômico do interior, decorrente desta interiorização do desenvolvimento, pode ser percebido especialmente na Região de Campinas e da Bacia do Piracicaba, pelo crescimento acelerado dos parques industriais, sobretudo metal-mecâncio e agroindustrial.

Uma característica marcante na região da Bacia do Piracicaba, referese ao intenso encadeamento entre a produção industrial e a agrícola, como as agroindústrias de cana, laranja, papel e papelão, e laticínios (SMA, 1994).

Em relação à indústria, o que se percebe é um extraordinário crescimento no período 1970/85, elevando sua participação no VTI (Valor da Transformação Industrial) estadual de $6,3 \%$ para $12,7 \%$, estimando-se que em 1990 essa participação tenha se elevado para $13,6 \%$.

Para destacar a importancia da indústria da Bacia do Piracicaba no cenário nacional, vale mencionar que, para 1990, estima-se que a mesma respondia por $6,7 \%$ do VTI da indústria de transformação do Brasil (NEGRI, 1992).

O setor terciário da região também ganhou mais expressão, principalmente nos anos 80 , com a instalação de importantes estabelecimentos comerciais (atacado e varejo) e de prestação de serviços nos principais municípios da Bacia, com destaque para a instalação de 
Hipermercados e Shopping Centers, conformando um dinâmico centro prestador de serviços

\subsubsection{Demanda pela Água e Poluição dos Recursos Hídricos}

$O$ intenso processo de urbanização da região das bacias do Piracicaba e Capivari, contribuiu significativamente para o aumento da demanda pela água. De igual forma, aumentaram-se ainda mais os problemas resultantes deste acelerado crescimento das atividades urbanas, com o comprometimento gradativo dos recursos hídricos pelo aumento da concentração de atividades poluidoras e as dificuldades cada vez maiores de se fornecer água em quantidade suficiente e qualidade adequadas

As demandas de água nesta região, destinam-se ao abastecimento urbano, inđustrial e agrícola. Além dessas utitizações, é importante destacar as transferências de água da Bacia do Piracicaba para o abastecimento da Região Metropolitana de São Paulo (RMSP), em função do "Projeto Cantareira de Abastecimento da Grande São Paulo", idealizado e implantado no final dos anos 60 , cuja demanda atual corresponde a um volume aproximado de cerca de $31 \mathrm{~m}^{3} / \mathrm{s}$. Essa água exportada para a RMSP não volta mais para a Bacia do Piracicaba, nem mesmo na forma de esgoto. (NEGRI, 1992; SMA, 1994)

A quantidade de água captada na Bacia do Piracicaba a jusante do Sistema Cantareira é estimada em $26,679 \mathrm{~m}^{3} / \mathrm{s}$, sendo $49 \%$ para o setor industrial, $37 \%$ para o urbano e $14 \%$ para a irrigação agricola. Desse total, parte não retorna aos corpos d’água, sendo incorporada aos produtos industriais, aos seres vivos, ou simplesmente se perdendo no ar e no solo. Essa parcela foi estimada em $14,204 \mathrm{~m}^{3} / \mathrm{s}$, sendo $41 \%$ para o setor industrial, $33 \%$ para o urbano e $26 \%$ para o agropecuário. (SMA, 1994).

O retrato do atual uso das águas nas bacias do Piracicaba e Capivari encontra-se apresentado no QUADRO 5.4. 
QUADRO 5.4 - Bacias dos Rios Piracicaba e Capivari - Retrato do Uso das

Águas

\begin{tabular}{|c|c|c|c|c|c|}
\hline \multirow[t]{2}{*}{ Usos } & \multicolumn{2}{|c|}{$\begin{array}{c}\text { Captado nos rios } \\
\left(\mathrm{m}^{3} / \mathrm{s}\right)\end{array}$} & \multicolumn{2}{|c|}{$\begin{array}{l}\text { Devolvido como } \\
\text { esgoto/efluente }\left(\mathrm{m}^{3} / \mathrm{s}\right)\end{array}$} & \multirow{2}{*}{$\begin{array}{c}\text { Tratamento } \\
\text { atual }\left({ }^{* *}\right) \\
\%\end{array}$} \\
\hline & 1992 & 1995 & 1992 & 1995 & \\
\hline Industrial & 14,3 & 16,6 & 11,9 & 13,8 & 76 \\
\hline Urbano & 12,3 & 12,6 & 9,8 & 9,0 & 3 \\
\hline Agricola & 5,8 & 6,8 & 0,0 & 0,0 & - \\
\hline \multicolumn{6}{|l|}{ Outros usos $\left(^{*}\right)$} \\
\hline Grande S. Paulo & 33,0 & 33,0 & 0,0 & 0,0 & - \\
\hline Jundiaí & 1,2 & 1,5 & 0,0 & 0,0 & - \\
\hline Indaiatuba & 0,1 & 0,2 & 0,0 & 0,0 & - \\
\hline Total & 77,9 & 82,2 & 21,7 & 22,8 & 56 \\
\hline
\end{tabular}

Fonte: Relatório do Consórcio Piracicaba-Capivari apud MONTICELI \& MARTINS, 1993

(*) Reversão para fora das bacias para abastecimento público

$\left({ }^{\star \star}\right)$ Exclui engenhos e usinas

A grande reversão de água para a RMSP através do Sistema Cantareira, aliada à elevação da demanda provocada pelo processo de interiorização, podem comprometer a quantidade e a qualidade de água disponivel para os próximos anos na região.

Além disso, o incremento das atividades urbanas, agroindustriais e industriais também contribuiram significativamente para o aumento da carga poluidora lançada nos corpos d'água, agravando ainda mais a situação dos recursos hidricos disponiveis.

Com o aumento populacional e da cobertura da rede de coleta de esgoto dos municipios (atualmente na casa dos $80 \%$ ), elevou-se consideravelmente a carga orgânica de uso doméstico produzida na bacia, agravado pelo fato de que apenas uma pequena porcentagem deste esgoto é tratada (menos de $5 \%$ do total).

O processo de interiorização da indústria atraiu para a região da Bacia do Piracicaba uma série de estabelecimentos industriais com grande potencial poluidor como são os casos da indústria alimentícia, quimica e de papel e celulose. 
A agroindústria canavieira que sempre caracterizou-se por sua grande capacidade em termos de carga poluidora, expandiu-se brutalmente após 1975 com o advento do PROÁLCOOL, consolidando-se como a principal responsável pela carga poluidora regional; mesmo com o aperfeiçoamento na legislação ambientał e das ações desenvolvidas pela CETESB, a atuat carga poluidora remanescente das atividades industriais (cerca de $4 \%$ do total), equivale a quase toda carga poluidora remanescente dos esgotos domésticos da população urbana da Bacia do Piracicaba. (NEGRI, 1992).

O QUADRO 5.5 apresenta o total da poluição por atividade na bacia.

Quadro 5.5 - Total da Poluição em Kg de $\mathrm{DBO}_{5} /$ dia

\begin{tabular}{|c|c|c|c|c|}
\hline DBO & $\begin{array}{c}\text { Domiciliar } \\
\text { (cidades) }\end{array}$ & Indústrias & $\begin{array}{c}\text { Engenhos e } \\
\text { Usinas }\end{array}$ & TOTAL \\
\hline Produzida & 114.000 & 310.000 & 1.363 .000 & 1.787 .000 \\
\hline Remanescente & 110.580 & 74.400 & 27.260 & 212.240 \\
\hline
\end{tabular}

Fonte: MONTICELI \& MARTINS, 1993.

Uma espécie de poluição dos recursos hídricos que ainda não foi avaliada em toda a sua extensão nas bacias dos rios Piracicaba e Capivari, refere-se à contaminação por agrotóxicos. A Região de Campinas é uma grande produtora de itens agricolas no Estado de São Paulo, perdendo apenas para a região de Ribeirão Preto. A prática agrícola na área das duas bacias é intensiva, com o uso expressivo de produtos agroquímicos e irrigação. Atualmente, $\circ$ uso de água em irrigação atinge cerca de $6 \mathrm{~m}^{3} / \mathrm{s}$, devendo mais que dobrar até o ano 2010, mantidas as atuais tendências, como mostra o QUADRO 5.6. 
QUADRO 5.6 - Bacias dos Rios Piracicaba e Capivari - Demandas para

Irrigação

\begin{tabular}{|l|r|r|r|r|r|r|}
\hline \multirow{2}{*}{ Sub-Bacias } & \multicolumn{2}{|c|}{1990} & \multicolumn{2}{c|}{1995} & \multicolumn{2}{c|}{2000} \\
\cline { 2 - 7 } & $\begin{array}{c}\text { Área (ha) } \\
\text { Irrigada }\end{array}$ & $\begin{array}{c}\text { Dem. } \\
\text { Máx. (I/s) }\end{array}$ & $\begin{array}{c}\text { Área (ha) } \\
\text { Irrigada }\end{array}$ & $\begin{array}{c}\text { Dem. } \\
\text { Máx. (I/s) }\end{array}$ & $\begin{array}{c}\text { Área (ha) } \\
\text { Irrigada }\end{array}$ & $\begin{array}{c}\text { Dem. } \\
\text { Máx. (I/s) }\end{array}$ \\
\hline Jaguari & 6.987 & 1.467 & 8.500 & 1.785 & 10.342 & 2.171 \\
Atibaia & 3.500 & 910 & 4.258 & 1.108 & 5.180 & 1.347 \\
Piracicaba & $\mathbf{4 . 4 2 8}$ & $\mathbf{1 . 6 8 3}$ & $\mathbf{5 . 9 2 5}$ & $\mathbf{2 . 2 5 2}$ & $\mathbf{7 . 9 3 0}$ & $\mathbf{3 . 0 1 3}$ \\
Corumbatai & 1.478 & 459 & $\uparrow .576$ & 615 & 2.110 & 823 \\
\hline Sub-Total & 16.093 & 4.519 & 20.259 & 5.760 & 25.562 & 7.354 \\
\hline Capivari & 2.132 & 810 & 2.853 & 1.084 & 3.818 & 1.451 \\
\hline Total & 18.225 & 5.329 & 23.112 & 6.844 & 29.380 & 8.805 \\
\hline
\end{tabular}

Fonte: Relatório do Consórcio Piracicaba-Capivari,1992 apud MONTICELI \& MARTINS, 1993.

Obs: $\quad 1 \mathrm{l} / \mathrm{s}=3,6 \mathrm{~m}^{3} / \mathrm{h}$

A contaminação dos recursos hídricos por agrotóxicos ocorre basicamente pelo processo de lixiviação. Já no processo de escoamento superficial (run-off), as águas das chuvas acabam levando os residuos de agrotóxicos para os corpos hidricos. Cerca de $90 \%$ da quantidade de agrotóxicos aplicados não atinge os alvos, ocorrendo a dispersão para o meio ambiente. (MONTICELI \& MARTINS, 1993).

A situação dos cursos d'água deteriora-se rapidamente com o uso abusivo dos recursos hidricos e as contaminações advindas das indústrias, cidades e atividades agropecuárias. As perspectivas para a região das bacias do Piracicaba e Capivari apontam para a continuidade do intenso crescimento populacional urbano e industrial.

Adotando-se um horizonte de mais vinte anos, a demanda total de água na região e a carga poluidora remanescente poderão crescer mais de $50 \%$. Com isso, a região das bacias dos rios Piracicaba e Capivari poderá apresentar um futuro preocupante em pelo menos quatro aspectos:

a) desequilíbrio acentuado entre demanda de águas e disponibilidade de recursos hidricos:

b) conflitos entre os usuários dos mananciais em prejuizo dos municipios localizados na Sub-Bacia do Piracicaba; 
c) comprometimento da qualidade da água para o abastecimento e para a saúde pública, caso não se elevem os níveis de tratamento do esgoto doméstico e da carga orgânica industrial;

d) aumento do custo de captação, tratamento e distribuição da água para consumo com reflexo sobre as tarifas de água e de coleta de esgoto.

A sociedade regional tem procurado organizar-se no sentido de que as autoridades - municipais e estaduais - bem como os empresários tomem providências para solucionar os problemas de abastecimento de água e de poluição nas bacias.

Caso a sociedade regional não se organize e se mobilize ainda mais, a disponibilidade e a qualidade dos recursos hídricos nas bacias do Piracicaba e Capivari poderão, no limiar do século $X X I$, se tornar um fator limitante do desenvolvimento econômico e social da mais importante região do interior paulista. Para se evitar isso é preciso aprimorar ainda mais a legislação ambiental existente e, estimular o setor público e privado para que realizem investimentos no tratamento de esgoto sanitário e industriat, saindo da atual fase de estudos e projetos para uma ação concreta que contribua para a solução da problemática dos recursos hídricos na região. (NEGRI, 1992).

Essas parcelas de água que saem dos rios e não retornam mais à bacia hidrográfica, seja a parcela que vai para o Sistema Cantareira ou aquela perdida nos setores industrial, urbano e agropecuário, são responsáveis pelo contínuo esvaziamento dos rios. Por esta razão, é crescente o movimento pela cobrança pelo uso das águas, como elemento inibidor do uso perdulário dos rios. Dessa forma, indústrias, irrigantes e serviços de água e esgoto, tendo que pagar pelo uso da água, tenderão a operar seus sistemas com maior eficácia. Além de se pagar pelo uso da água, se pagará pelo esgoto devolvido, se o esgoto estiver tratado, 0 pagamento é menor. (MONTICELI \& MARTINS, 1993). 


\subsubsection{Histórico da Luta pela Despoluição dos Recursos Hídricos}

A percepção da sociedade civil com respeito à degradação dos recursos hídricos das bacias do Piracicaba e Capivari, tem estimulado a articulação de movimentos populares em toda a região.

Os primeiros a alertarem sobre o estado crítico de poluição do Rio Piracicaba foram os pescadores ao se depararem com os primeiros sintomas visiveis da poluição: a frequente mortandade de peixes. Este problema foi se agravando com o crescimento industrial e o adensamento das cidades, sendo posteriormente percebido por outros setores da comunidade.

Na segunda metade da década de 70 , alguns movimentos populares surgiram denunciando a degradação do Rio Piracicaba, fazendo uso de passeatas, manifestos e outros espécies de protestos, como o enterro simbólico do rio e a divulgação de uma foto do salto quase seco, onde foi colocada uma placa dizendo: "por aqui passava um rio". (SEBASTIANES, 1992).

Entre 1985 e 1988, a cidade de Piracicaba liderou o maior movimento social em defesa dos rios, de que se tem notícia no interior do Estado de São Paulo. O movimento, que ficou conhecido como "Campanha Ano 2000 - Redenção Ecológica do Rio Piracicaba", foi resultado da crescente preocupação da sociedade piracicabana com a queda na qualidade e na quantidade da água do Rio Piracicaba.

Inicialmente, a Divisão do Meio Ambiente da Associação dos Engenheiros e Arquitetos de Piracicaba começou a realizar reuniões e seminários locais, a preparar documentos e propostas. Dentro de pouco tempo, dezenas de associações, clubes de serviço, entidades da sociedade civil e autoridades públicas locais foram se agregando ao processo. O Conselho Coordenador de Entidades Civis de Piracicaba incorporou-se à 
luta, trazendo consigo as principais lideranças empresariais e políticas da cidade.

Ocorreram vários eventos, reuniões, e seminários em Piracicaba e outras cidades próximas, alertando para a terrivel situação da morte lenta e agonizante do Rio Piracicaba. A Associação de Engenheiros e Arquitetos de Piracicaba preparou vários documentos para justificar e divulgar o movimento. O principal deles foi a chamada "Carta de Reivindicações ao Governo Quércia", entregue pessoalmente ao governador por uma comissão organizada pelo Conselho Coordenador de Entidades Civis de Piracicaba, tendo as lojas maçônicas um papel de destaque.

A "Carta de Reivindicações", apresenta em linguagem direta, com justificativas, uma lista de 32 reivindicações aos poderes públicos, principalmente ao estadual, as quais criticam as atuações de secretarias de estado e instituições como a CETESB (Companhia de Tecnologia de Saneamento Ambiental) e o DAEE (Departamento de Águas e Energia Elétrica). mas poupam a administração e o poder público municipat. (MONTICELI \& MARTINS, 1993).

Em 1987, obtém-se a primeira vitória da "Campanha Ano 2000", o recém criado Conselho Estadual de Recursos Hidricos (CRH) editou a Deliberação $n^{\circ} 5$, que declarou a Bacia do Piracicaba como critica quanto aos seus recursos hidricos e fixou um prazo de 120 dias para a proposição de programas prioritários pelo Grupo Técnico da Bacia do Piracicaba (GTPI). O prazo foi rigorosamente cumprido e o programa elaborado atendia à maioria das reivindicações da campanha exceto às ligadas ao Sistema Cantareira e às indenizações à Bacia. (SEBASTIANES, 1992).

As reivindicações acerca do Sistema Cantareira, elaboradas pelos engenheiros Nelson Rodrigues e José Elidney Pinto, exigiam que a Bacia do Rio Piracicaba fosse indenizada pelos prejuízos causádos pela reversão de água para o abastecimento da Região Metropolitana de São Paulo (RMSP), 
- que significaria pagar pela água captada e revertida. Esta exigência, a $28^{a}$ reivindicação, desdobra-se em outras três, as de números 29,30 e 31 .

As reivindicações $n^{\text {os }} 29$ e 30 exigiam que os recursos indenizatórios fossem obrigatoriamente aplicados como investimentos, (não para custeio de salários) para utilização em obras e serviços de recomposição ambiental, prioritariamente tratamento de esgoto e reflorestamento das áreas de vegetação de preservação permanente. $E$, mais ainda, a reivindicação $n^{\circ} 31$ : "que estes recursos sejam recolhidos ao organismo intermunicipal da Bacia do Piracicaba". Este organismo intermunicipal, também era uma reivindicação, a de $n^{0} 19$, que propunha a "criação de um organismo intermunicipal eleito e representante de um Conselho Diretor de Prefeitos da Bacia". (MONTICELI \& MARTINS, 1993).

Numa iniciativa pioneira, algumas Prefeituras de cidades da bacia se uniram para fundar o "Consórcio Intermunicipal das Bacias dos Rios Piracicaba e Capivari". Eram as administrações públicas abraçando a luta pela recuperação do Rio Piracicaba e do Capivari.

A "Campanha Ano 2000" e os trabalhos desenvolvidos pelo Consórcio tiveram como um dos primeiros grandes resultados, a Lei Estadual $n^{\circ} 39 / 91$, assinada peto Governador Fleury em 30/12/91, que cria os Limites das Bacias dos Rios Piracicaba-Capivari-Jundiai e a do Alto Tietê, os quais vem fornecendo subsidios para a formação de comitês de bacias no Estado. (SEBASTIANES, 1992)

\subsubsection{O Comité e o Consórcio Intermunicipal das Bacias}

A lei estadual 7.663/91 de 30/12/91, instituiu a Política Estadual de Recursos Hidricos e o Sistema Integrado de Gerenciamento de Recursos Hidricos. Em linhas gerais, os princípios básicos que norteiam esta lei são o gerenciamento descentralizado e integrado dos recursos hídricos, a adoção da bacia hidrográfica como unidade físico-territorial de planejamento e 
gerenciamento e o reconhecimento do recurso hídrico como um bem público, de valor econômico, que deve ser cobrado.

Dentre as diretrizes que esta lei definiu para a Política Estadual de Recursos Hídricos, destacam-se o uso racional da água, sendo 0 abastecimento público prioritário em relação aos demais usos, e a maximização dos benefícios advindos do aproveitamento múltiplo.

Foram definidos como instrumentos desta Política, a outorga dos direitos de uso, infrações e penatidades, a cobrança pelo uso e o rateio de custos. Outro instrumento, é o Plano Estadual de Recursos Hídricos (PERH), elaborado de forma integrada pelos órgãos componentes do Sistema Integrado de Gerenciamento de Recursos Hídricos (SIGRH), composto por dois tipos de colegiados tripartites (Estado, Municípios e Sociedade Civil), $\sigma$ primeiro de nivel estadual, o Conselho Estadual de Recursos Hidricos (CRH), e o segundo regionat, os Comitês de Bacias Hidrográficas (CBH's).

A lei também prevê que, nas bacias onde os problemas relativos aos recursos hídricos assim o justificarem, e por aprovação do Comitê das Bacias Hidrográficas respectivo, pode ser criada, através de lei especifica, a Agência de Bacias - entidade jurídica, vinculada ao Estado, com estrutura administrativa e financeira própria.

Como suporte financeiro às ações propostas peto $\mathrm{PERH}$, foi instituído - Fundo Estadual de Recursos Hídricos (FEHIDRO) para o qual estão previstas como receitas, recursos do Estado, União e Municípios e empréstimos externos.

Por contar com uma forte mobilização e reconhecimento geral a respeito dos problemas que se pretendia eliminar (com interesses de lideranças locais e de órgãos estaduais e municipais) o primeiro comitê a ser criado foi o Comitê das Bacias Hidrográficas dos Rios Piracicaba, Capivari e Jundiai (CBH-PCJ). 
Embora esses três rios, afluentes da margem direita do Rio Tietê, possuam bacias hidrográficas distintas geograficamente, as mesmas têm ligação hídrica causada pela ação do homem.

A cidade de Jundiaí, na bacia do rio que the dá o nome, é abastecida por uma reversão da bacia do rio Atibaia (formador do Piracicaba). A cidade de Campinas, com área urbana dividida entre as bacias do Atibaia e Capivari, capta principalmente no Rio Atibaia e lança quase a metade de seus esgotos na Bacia do Capivari. Além dessas relações físicas, as três bacias estão situadas numa mesma região geopolitica.

O processo de instalação do $\mathrm{CBH}-\mathrm{PCJ}$ constituiu-se de duas fases. A primeira, de setembro/92 a junho/93, envolveu especificamente o Departamento de Águas e Energia Elétrica (DAEE), a Secretaria do Meio Ambiente (SMA) e a Fundação do Desenvolvimento Administrativo (FUNDAP). A segunda, de julho/93 a novembro/93, formou um Grupo Executivo Regional composto de representantes do Estado (DAEE, SMA, CETESB e FUNDAP) e dos Municípios (indicados pelo Consórcio Piracicaba-Capivari e pela Bacia do Jundiaí. O CBH-PCJ foi finatmente instalado em 18 de novembro de 1993, na Câmara Municipal de Piracicaba, com a eleição e cerimônia de posse de seus membros. (CBH-PCJ, 1996).

O modelo de Comitê e Agência de Bacia, com base na cobrança pelo uso das águas e utilização vinculada destes recursos no apoio aos municipios e indústrias, para obras contra a poluição dos rios e proteção dos mananciais, é um sucesso na França há trinta anos. Neste pais, os usuários das águas (indústrias e serviços de água e esgoto, principalmente) têm predominio discreto no Comitê e Agência. Os demais agentes acatam este predomínio dos usuários como forma de conseguir a efetiva participação daqueles que pagam e mais poluem. Não basta a força da lei, é necessário estar convencido a cumpri-la. Os infratores, minoria, são severamente punidos e os que investem contra a poluição, são recompensados. A confiança no sistema francês reside na correta definição das prioridades a investir, probidade no uso do recurso financeiro, transparência e controte 
pela sociedade, e principalmente no fato de que o dinheiro é arrecadado e repassado aos órgãos públicos e privados pela Agência da Bacia.

Outro instrumento importante de organização regional existente na região das bacias do Piracicaba e Capivari é o Consórcio Intermunicipal das Bacias dos Rios Piracicaba e Capivari, uma associação de municipios que pretende integrar os prefeitos, vereadores e entidades civis da região no combate à poluição.

O Consórcio Piracicaba-Capivari, foi fundado em Americana em outubro de 1989, com o intuito de ser uma resposta à própria falência dos modelos tradicionais de execução de políticas públicas em saneamento e meio ambiente no Brasil

Para chegar à sua fundação foi necessário quase um ano de negociações, reuniões, avanços e recuos, uma vez que a integração de prefeitos de vários partidos não é tão simples, em decorrência da tradição política brasileira de desconfiança e isolamento entre municipios, e da dependência perante o governo do estado e órgãos ministeriais.

O prestígio do Consórcio Piracicaba-Capivari tem muito a ver com sua busca de independência política perante o Estado e a União. Mais que uma frente política supra-partidária, que reúne municípios de grande importância econômica no país, responsáveis por $10 \%$ do PIB nacional, os prefeitos consorciados estão, eles próprios, colocando recursos em um caixa regional, para programas de proteção e recuperação dos rios, a nivel de bacia hidrográfica. (MONTICELI \& MARTINS, 1993).

No QUADRO 5.7 são apresentadas as principais diferenças entre o Consórcio Intermunicipal das Bacias dos Rios Piracicaba e Capivari e o CBH-PCJ. 
QUADRO 5.7 - Síntese das Principais Diferenças entre o Consórcio Intermunicipal das Bacias dos Rios Piracicaba e Capivari e o CBH-PCJ

\begin{tabular}{|c|c|c|}
\hline TEMA & CONSÓRCIO & CBH-PCJ \\
\hline Composiçāo & $\begin{array}{l}\text { Prefeitos e representantes de empresas } \\
\text { consorciadas (Conselho de Municípios) }\end{array}$ & $\begin{array}{l}\text { Prefeitos ou representantes de todos os } \\
\text { municípios das bacias; representantes } \\
\text { das entidades estaduais e da sociedade } \\
\text { civil }\end{array}$ \\
\hline Poder de decisão & $\begin{array}{l}\text { Conselho de Municipios } \\
\text { (Prefeitos e representantes de } \\
\text { empresas) }\end{array}$ & $\begin{array}{l}\text { Dividido paritariamente entre os } 3 \\
\text { segmentos }\end{array}$ \\
\hline Personalidade juridica & Sociedade civil de direito privado & Não tem \\
\hline Criaçào e atuação & $\begin{array}{l}\text { Criado em out/89, por iniciativa dos } \\
\text { prefeitos (autorizados por leis } \\
\text { municipais), organiza planos anuais de } \\
\text { trabaltho, com base nos recursos } \\
\text { proprios e dos paceiros pútblicos ou } \\
\text { privados, atuando princtpatmente em } \\
\text { esgoto. lixo reflorestamento ciliar, } \\
\text { educação ambiental e apio aos membros } \\
\text { consoricados. Possui cooperação com } \\
\text { entidades da França e México. Defende } \\
\text { a criação de gestä́o descentratizada, } \\
\text { fazendo propostas institucionais ao } \\
\text { Comitê e aos governos estadual e } \\
\text { federal. }\end{array}$ & $\begin{array}{l}\text { Criado por lei estadual, instalou-se em } \\
\text { nov/93, cumpriu suas atribuiçóes legais, } \\
\text { aprovando planos de bacias e relatórios } \\
\text { de situaçáo. Propós anteprojetos de lei } \\
\text { para criação de Agência de Bacias, } \\
\text { sensibilizou parlamentares para a } \\
\text { questáo dos recursos hidricos e } \\
\text { fomentou o inicio de funcionamento do } \\
\text { FEHIDRO, propondo investimentos em } \\
\text { projetos e obras. Implantado como } \\
\text { experiência piloto. serviu de base para a } \\
\text { instalação e inicio de funionamento dos } \\
\text { demais CBH's. }\end{array}$ \\
\hline Equipe Técnica de Apoio & $\begin{array}{l}\text { Própria e contratada. Possui convênio } \\
\text { com a CESP e outras instituriçóes. } \\
\text { Terciriza grande parte dos serviços. }\end{array}$ & $\begin{array}{l}\text { Da Secretaria Executiva e dos órgãos } \\
\text { estaduais pertencentes ao Comitê } \\
\text { Coordenador do Plano Estadual de } \\
\text { Recursos Hidricos (CORHI), dos } \\
\text { municípios, do próprio Consórcios e } \\
\text { eventualmente da sociedade civit. Os } \\
\text { técnicos subsidiam as discussões nas } \\
\text { Cámaras e Grupos Técnicos, que } \\
\text { propóem documentos para a aprovação } \\
\text { no plenário. }\end{array}$ \\
\hline Recursos finamceiros & $\begin{array}{l}\text { Contribuições dos consorciados. As de } \\
\text { custeio são mensais e as para } \\
\text { investimentos são fixadas de acordo } \\
\text { com programas especificos (A } \\
\text { contribuição de investimentos está } \\
\text { suspensa descle 1993). }\end{array}$ & $\begin{array}{l}\text { Os recursos de custeio são de } \\
\text { responsabilidade da entidade } \\
\text { responsável pela Secretaria Executiva e } \\
\text { eventualmente complementados por } \\
\text { entidades membro. Aguarda-se para o } \\
\text { segunto semestre/96 a liberação de } \\
\text { recursos de custeio do FEHIDRO. } \\
\text { especificos para utilização da Sec. } \\
\text { Executiva. Quanto aos investimentos, } \\
\text { cabe ao CBH decidir pela alocação e } \\
\text { priorizar a apticação dos recursos do } \\
\text { FEHIDRO (e da cobrança quando } \\
\text { instituida). }\end{array}$ \\
\hline Comunicação Social & $\begin{array}{l}\text { Através de profissionais especializados } \\
\text { produz videos, publicaçōes e } \\
\text { informativos para divulgação e e } \\
\text { sensibilização. }\end{array}$ & $\begin{array}{l}\text { Não tem estrutura própria voltada para } \\
\text { essa atividade. Limita-se à ediçăo de } \\
\text { informativo, com apio de membros do } \\
\text { Comité. }\end{array}$ \\
\hline
\end{tabular}

Fonte: CBH-PCJ, 1996.

Com a percepção de que a luta dos municípios contra a poluição dos rios individualmente, não é mais eficaz, técnica e economicamente e a constatação de que os problemas são regionais (um municipio dependendo das obras do outro), a criação de entidades como o Comitê das Bacias Hidrográficas dos Rios Piracicaba, Capivari e Jundiai (CBH-PCJ) e o 
Consórcio Intermunicipal das Bacias dos Rios Piracicaba e Capivari, destacou o pioneirismo desta região no combate à degradação dos recursos hídricos.

\section{2. Órgão Responsável: SEMAE - Piracicaba}

O SEMAE (Serviço Municipal de Água e Esgoto) de Piracicaba - SP, foi criado em 30 de abril de 1969, através da Lei Municipal $n^{\circ}$. 1657, tendo sido regulamentado pelo decreto $n^{\circ}$. 828, de 30 de maio do mesmo ano. Em agosto de 1969, Piracicaba já contava com vários projetos de rede de esgoto e de fornecimento de água. Com isso a autarquia ganhava autonomia econômica, financeira e administrativa.

Nove anos depois (1978), o SEMAE construiu uma pequena represa, três reservatórios e uma casa de máquinas. Em outubro, a sede foi transferida para a Rua XV de Novembro, 2.200 - onde funciona até hoje.

Em 1982, com a inauguração da ETA - Capim Fino, novas perspectivas foram abertas para o município.

Em 1989, foi elaborado um Plano Diretor de Água, que gerou as diretrizes e projetos básicos para o desenvolvimento do sistema de água.

Com o lançamento da primeira estação de tratamento de esgotos (ETE - Dois Córregos), em dezembro de 1992, iniciava-se um projeto pitoto com capacidade para tratar esgotos de até 1000 (mil) habitantes. Um ano depois, O SEMAE deu os primeiros passos para aumentar o indice de tratamento de esgotos da cidade, iniciando a instalação de interceptores de esgoto às margens do Córrego das Ondas e na margem direita do Ribeirão Piracicamirim. 
Em junho de 1998 o SEMAE inaugura a ETE - Piracicamirim, dimensionada para tratar o esgoto doméstico de uma população de 90 mil pessoas. Uma obra caracterizada pelo seu baixo custo de construção e manutenção, cujo projeto foi desenvolvido pelo Prof. Dr. José Roberto Campos (USP - S. Carlos). A ETE é tão significativa que tem atraído a atenção de outros serviços de água e esgoto do país e de outros paises, como Colômbia, Chile, Estados Unidos e México.

Em matéria de abastecimento, a cidade de Piracicaba conta hoje com três Estações de Captação: duas no rio Piracicaba e uma no rio Corumbataí. Além disso, o sistema de abastecimento da cidade está informatizado. Hoje é possivel saber qual a quantidade de cloro ou de água em cada reservatório on-line, de uma central instalada na sede da autarquia. $\dot{E}$ possivel ainda, remanejar água de um reservatório para outro, destigar e ligar bombas para economizar energia ou para sanar problemas emergenciais.

Entre projetos, estudos e avaliações, o SEMAE tem procurado estar presente no dia-a-dia de Piracicaba, buscando soluções alternativas capazes de melhorar a qualidade de vida do povo piracicabano e investindo em pesquisas e projetos que antecipem soluções para questões futuras

O SEMAE também investe em projetos ecológicos, como é o caso da Semana da Água que acontece anualmente ou os projetos experimentais com alternativas para o tratamento de esgotos e recomposição de matas ciliares.

A autarquia tem a competência de exercer todas as atividades relacionadas com o sistema público de água e esgoto do Município de Piracicaba.

Seu primeiro presidente foi o Dr. Paulo Geraldo Serra e o atual é o Engenheiro Civil José Augusto B. Seydel (SEMAE, 2002). 
O QUADRO 5.8 apresenta um retrato do SEMAE - Piracicaba, em termos numéricos (ligações de água, reservatórios, dentre outros).

\section{QUADRO 5.8 - O SEMAE em Números}

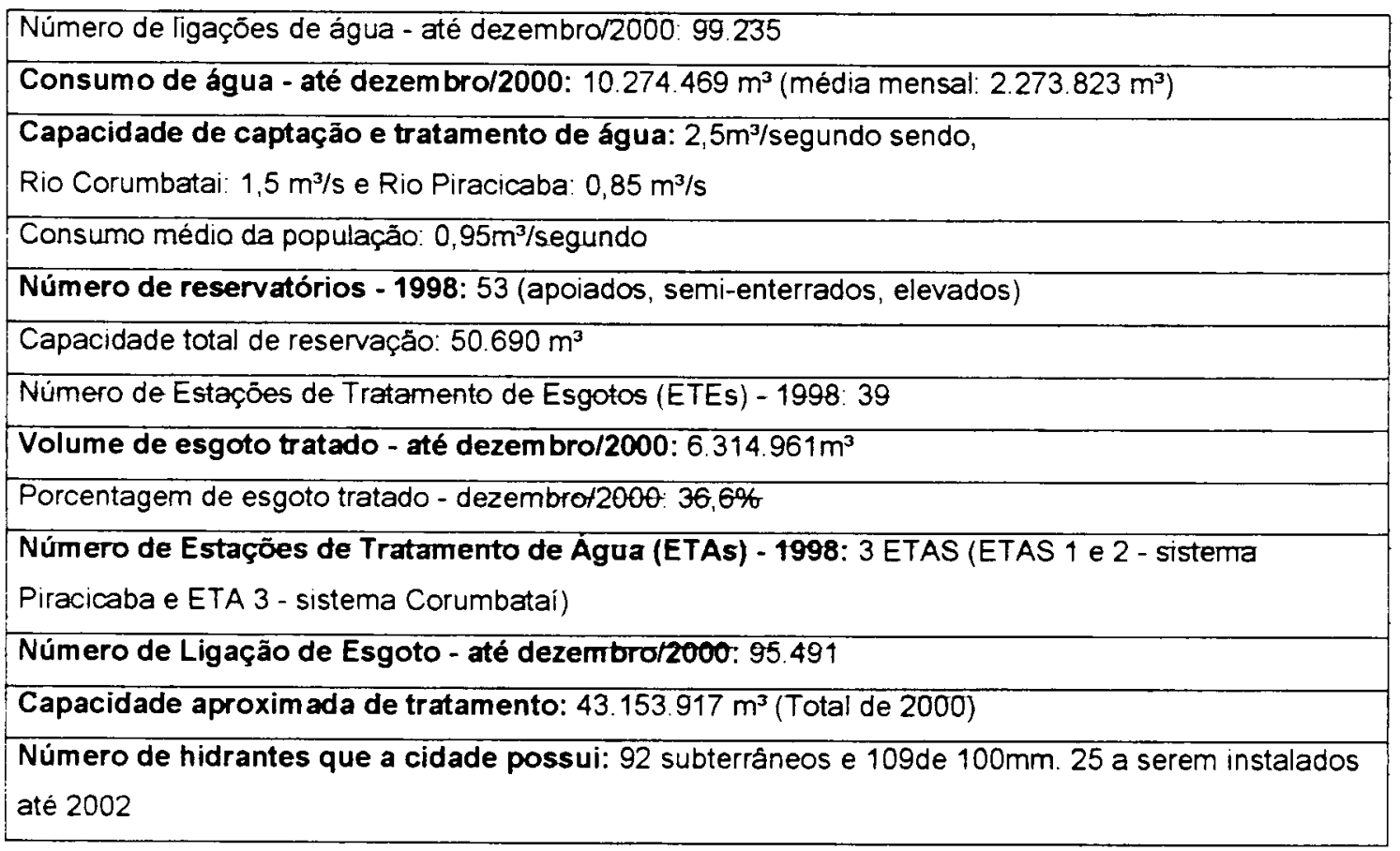

Fonte: Depto. de Engenharia - SEMAE - março/2001.

\subsubsection{Curiosidades Históricas}

\section{4}

O problema de abastecimento de água começa a preocupar a Câmara de Vereadores

\section{6}

abril - Inicia-se, sob a responsabilidade do construtor itatiano Cartos Zanotta e do engenheiro hidráulico português João Frick, a construção do primeiro reservatório da cidade: o reservatório de 2 milhões de litros, localizado no bairro dos Alemães, hoje conhecido como reservatório da Rua Marechal Deodoro. 


\section{6 a 1924}

Nesse periodo Piracicaba possuía 4.129 casas urbanas das quais apenas 2.583 tinham rede de esgoto.

\section{9}

abril - A Câmara aprova o projeto de autarquia do então prefeito Dr. Francisco Salgot Castillon, sobre a transformação do Serviço Municipal de Água e Esgoto através da lei 1657, em substituição ao DAE (órgão subordinado à Secretaria de Obras e Serviços Urbanos). Com isso, 0 Serviço ganhava autonomia econômica, financeira e administrativa. A autarquia ocupou por oito anos as instalações do antigo DAE, à Rua São José. 655 .

1978

outubro - A sede do SEMAE é transferida para a Rua XV de Novembro, 2.200 .

1980

agosto - Lançamento da pedra fundamental da ETA Capim Fino.

1982

maio - Inauguração da ETA Capim Fino, que capta água de methor qualidade

1983

Nesse ano cerca de 53.911 prédios da cidade eram abastecidos com água tratada e 50.997, servidos pela rede de esgoto.

1987

maio - Comemoração do Centenário da Água encanada em Piracicaba. 
1992

novembro - Inauguração da primeira Estação de Tratamento de Esgotos ETE, no Bairro Dois Córregos.

1993

outubro - Início da construção da Estação Elevatória de Água Tratada do Capim Fino.

dezembro - O SEMAE inicia a instalação de interceptores de esgoto no Córrego das Ondas e Ribeirão Piracicamirim.

1994

fevereiro - Início, com apoio da USP - São Carlos, dos estudos para implantação de uma ETE para o Ribeirão Piracicamirim, que recebe esgotos de 60 mil habitantes.

1995

A cidade tinha 960 quilômetros de rede de esgoto de 1.120 quilômetros da rede de água.

março - A ESALQ-USP doa área à Prefeitura para a construção da Estação de Tratamento de Esgoto do Ribeirão Piracicamirim.

abril - Bombeiros e SEMAE se unem para instalar mais hidrantes na cidade. agosto - Inaugurado o novo sistema (informatizado) de atendimento através do fone 195

outubro - De 2 a 7 aconteceu a Semana da Água em Piracicaba organizada pelo SEMAE.

novembro - O SEMAE inaugura a primeira etapa da automação da Distribuição de Água. 
1996

janeiro - Início dos trabalhos de despoluição da Bacia do Ribeirão do Enxofre e instalação de interceptores de esgoto no Córrego Tatuapé. novembro - Início da construção da ETE - Piracicamirim.

1997

agosto - O SEMAE inicia a implantação do sistema piloto de geoprocessamento. Esse sistema reúne softwares e hardwares que armazenam no computador o mapeamento da cidade, feito por meio de imagens digitalizadas e obtidas por meio de levantamento aerofotométrico.

A última etapa do sistema de automatização đo abastecimento é implantada.

1998

abril - Dia 24 - Anunciado no gabinete do Prefeito a desapropriação amigável de uma área de 400 mil metros quadrados no bairro Santa Terezinha, às margens da SP 304 (Piracicaba - São Pedro) para a construção da ETE - Principal, que irá tratar o esgoto de 300 mil habitantes. A autarquia pagará $R \$ 1,7$ milhão pela área.

junho - Dia 6 - Inaugurada a ETE - Piracicamirim, dimensionada para tratar o esgoto de 100 mil habitantes da Bacia do Ribeirão Piracicamirim. O projeto é de autoria do Prof. Dr. José Roberto Campos, da USP de São Carlos. A área, de 30 mil metros quadrados, foi cedida pela ESALQ (Escola Superior de Agricultura Luís de Queiróz), que também irá se utilizar do lodo produzido pela ETE para experiências de aplicação do mesmo na agricultura. A ETE, desde o final de sua construção, tem chamado a atenção de técnicos e especialistas pelo seu baixo custo e sistemas de tratamento (SEMAE, 2002). 


\subsubsection{Estações de Tratamento de Esgotos}

A cidade de Piracicaba através de seu órgão de saneamento (Serviço Municipal de Água e Esgoto - SEMAE) possui atualmente 45 estações de tratamento de esgotos, como apresentado no Quadro 5.9.

QUADRO 5.9 - Estações de Tratamento de Esgotos de Piracicaba - SP

\begin{tabular}{|c|c|}
\hline \multicolumn{2}{|c|}{ ETE } \\
\hline Piracicamirim & Sol Nascente I \\
\hline Tanquinho & Sol Nascente II \\
\hline Chácaras Unidas & Dois Corregos \\
\hline Sāo Jorge & Alvorada II \\
\hline Santa Olimpia & CECAP \\
\hline Anhumas & Jd. Bartira I - Tupi \\
\hline Curtume & Lago Azul \\
\hline Jupiá I & Jd. Bartira II - Tupi \\
\hline Jupiá II & Pq. Peória-Tupi \\
\hline Jupiá ||| & Jd. Altafim \\
\hline Jd Boa Esperança & Vale do Sol I \\
\hline Vila Belém & Vale do Solll \\
\hline Glebas Califórnia & Altos da Pompéia \\
\hline jd. Colonial & Santana I \\
\hline $1^{\circ}$ de Maio & Santana II \\
\hline Santa Silvia & Santana III \\
\hline Jd. Itamaracá & Santana IV \\
\hline Abaeté & Javari II \\
\hline Potiguar & Diamante \\
\hline Santa Inês I & Ourinhos \\
\hline Santa Inês II & Cadeião \\
\hline Chapadão & Engenho \\
\hline Lago Azul & Kobayat-Libano \\
\hline
\end{tabular}

Fonte: SEMAE, 2002.

OBS: Vazão total de esgoto tratado no mês: $96.368 \mathrm{m3}$. Vazão total de esgoto lançado na rede: $4.778 .599 \mathrm{m3}$.

A porcentagem de esgoto tratado em Piracicaba era da ordem de $5,4 \%$. Com a ETE - Piracicamirim, esse índice subiu para $33 \%$ (SEMAE, 2002). 


\subsection{Dados de Projeto e Informações Complementares}

\section{FIGURA 5.4 - Vista aérea da ETE Piracicamirim}

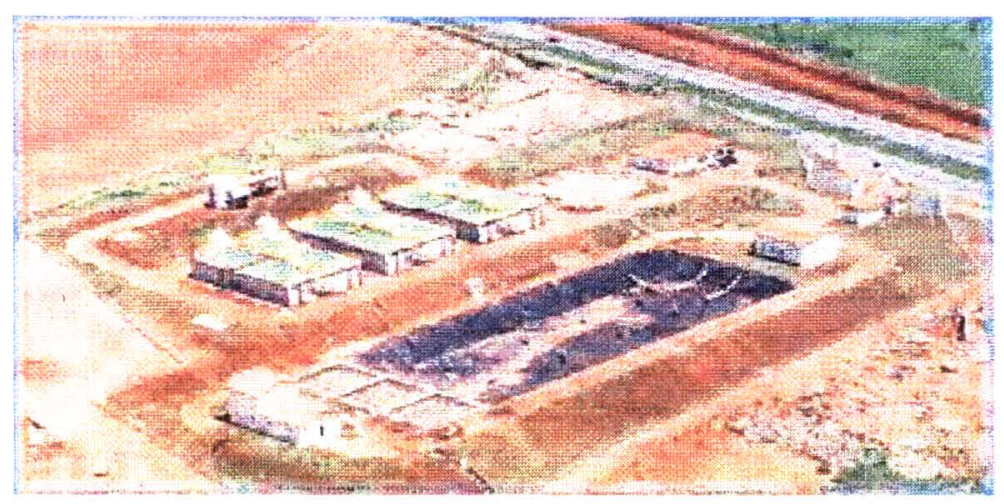

Fonte: SEMAE, 2002.

A ETE Piracicamirim (FIGURA 5.4) foi projetada para atender uma população de até 90 mil habitantes e está localizada nas terras da ESALQUSP, numa área de 30 mil metros quadrados. Seu principal objetivo é a despoluição do Ribeirão Piracicamirim, afluente do Rio Piracicaba.

Na ETE Piracicamirim o esgoto a ser tratado passa primeiramente pof gradeamento, medição de vazão e caixa de retenção de areia. Em seguida, o esgoto é conduzido aos reatores anaeróbios de fluxo ascendente (FIGURA 5.5), seguindo até o sistema aeróbio constituído de lagoa aerada e decantador.

FIGURA 5.5 - Reatores anaeróbios e tratamento de gás

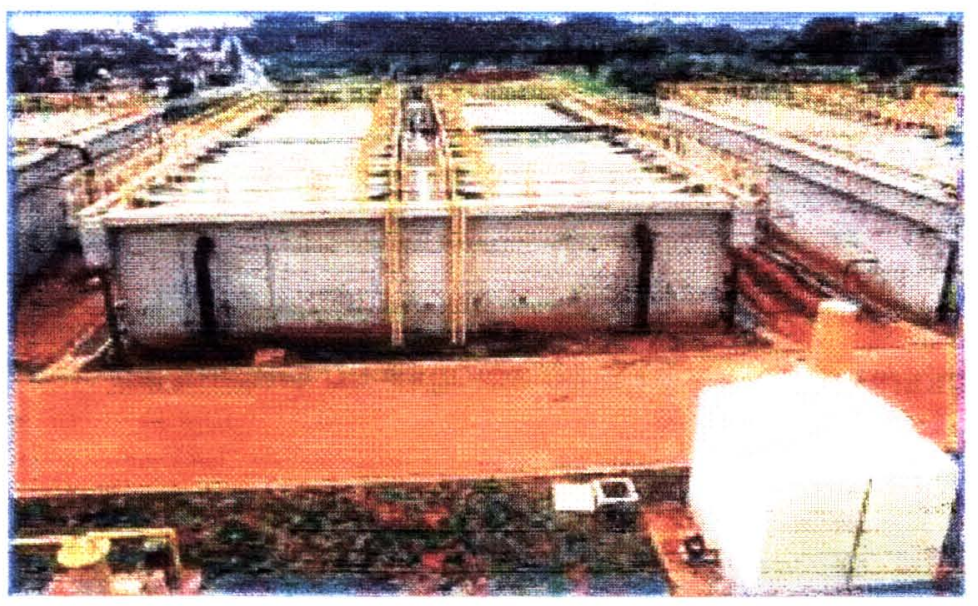

Fonte: SEMAE, 2002. 
A unidade principal de tratamento conta com várias unidades auxiliares que trabalham paralelamente, como: sistema de tratamento de gases, desidratação de lodo, queimador de gás, sistema de drenagem de areia. A eficiência esperada é de $97,3 \%$ em termos de DBO (Demanda Bioquímica de Oxigênio).

O SEMAE fez um acordo com a promotoria pública comprometendose a tratar $100 \%$ dos esgotos gerados pela cidade até 0 ano 2004 , garantindo não só a despoluição do Rio Piracicaba mas também de todos os córregos e ribeirōes do município. Este acordo está contemplando no Plano Diretor de Esgotos da cidade elaborado pelo SEMAE, que prevê a construção de outras ETES, vários coletores-tronco e interceptores (SEMAE, 2002).

\subsubsection{Dados Técnicos}

- Vazão final do plano $($ ano 2015$)=5901 / \mathrm{s}$

- Capacidade para tratar esgoto de 90 mil habitantes

- Área ocupada: 30 mil metros quadrados em terras da ESALQ-USP

- Área de contribuição: a bacia do ribeirão Piracicamirim (SEMAE, 2002)

$\mathrm{Na}$ FIGURA 5.6, tem-se um desenho esquemático representativo das unidades de tratamento de esgotos da ETE - Piracicamirim. 
FIGURA 5.6 - Esquema do Tratamento de Esgoto - ETE - Piracicamirim

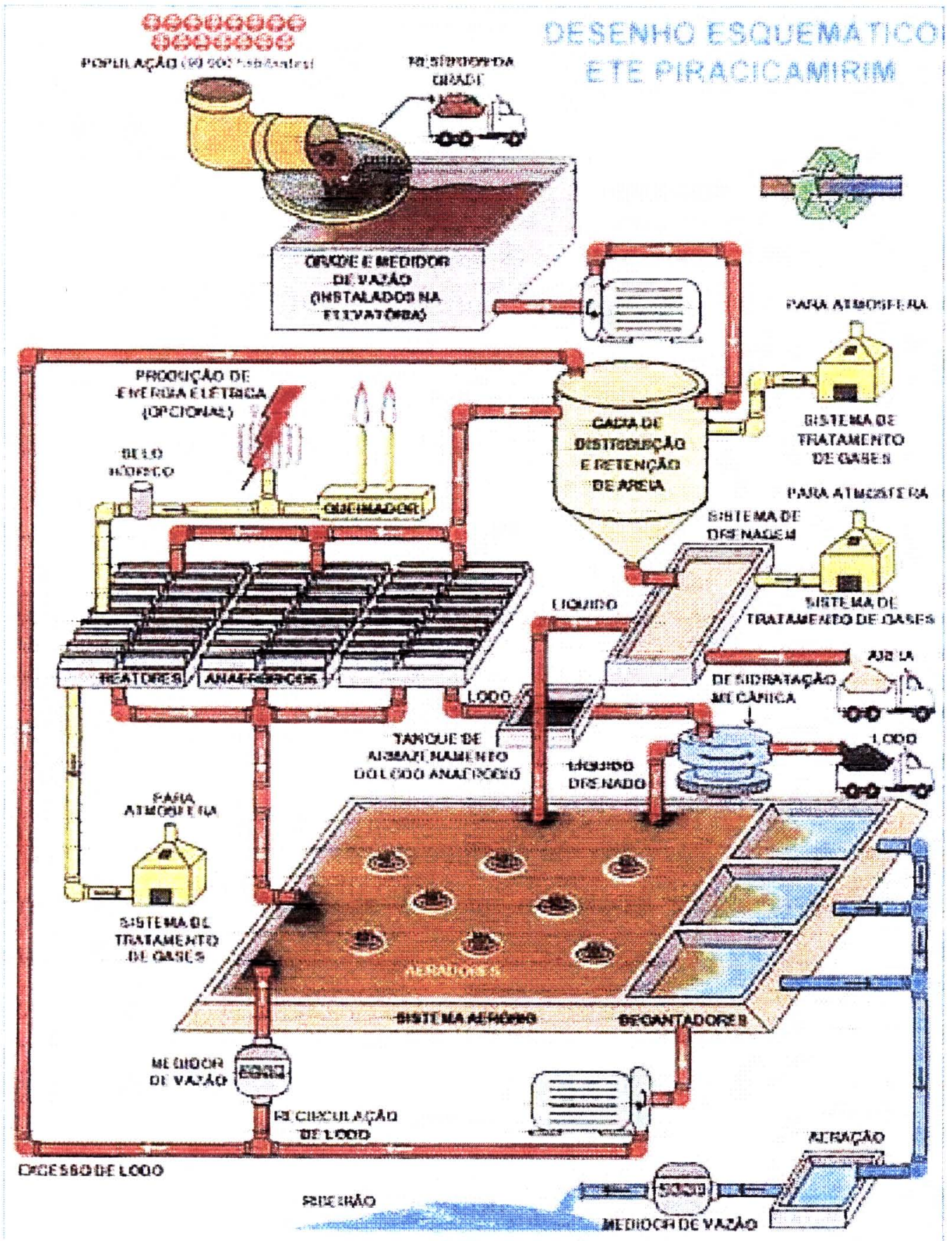

Fonte: SEMAE, 2002. 


\subsubsection{Unidades, Autoria do Projeto e Consórcio Executor}

Estação Elevatória de esgoto - situada às margens do ribeirão Piracicamirim, proximidades da Escola Estadual Jaçanã e SP-304. Recebe todo o esgoto da bacia do Piracicamirim e recalca para a ETE, localizada no ponto mais alto do terreno cedido pela ESALQ-USP - margem direita do ribeirão.

Caixa de areia e gradeamento - tem a finalidade de remover a areia e material volumoso.

Reatores Anaeróbios - de fluxo ascendente, consagrados no mundo todo como reatores UASB (upflow anaerobic sludge blanket). Funcionam ao mesmo tempo como decantador primário, reator biológico e digestor de lodo (CAMPOS et al., 1999).

Reator Aerado - uma lagoa com $9 \mathrm{mil} \mathrm{m}^{3}$ e oito aeradores, cuja finalidade é injetar oxigênio no esgoto, que por sua vez, é tratado, nessa fase, pelo processo aeróbio, atingindo uma eficiência de $97,3 \%$ na remoção da carga orgânica

Decantador Secundário - executado em concreto, com volume total de $3 \mathrm{mil} \mathrm{m}^{3}$ e com a finalidade de reter o material sólido produzido nos reatores aerados.

Tratamento do lodo - parte do lodo retirado no decantador é bombeada para o início do processo e o excesso é tratado, centrifugado e transportado para o local devidamente autorizado ou na agricultura.

Prédio Administrativo - com anfiteatro para reuniões e palestras, laboratório de análises e almoxarifado.

Manutenção - o prédio da oficina oferecerá suporte na manutenção de equipamentos e abrigará o almoxarifado central. 
Queimadores de Gases - a ETE possui equipamentos para a queima de gazes, assim como tratamento dos mesmos em local apropriado.

Autor do Projeto - o projeto da ETE Piracicamirim foi desenvolvido pelo professor José Roberto Campos da USP - São Carlos.

Consórcio Executor do Projeto - a construção da ETE Piracicamirim ficou a cargo das empresas consorciadas: COM. Engenharia e MBR Mascarenhas Barbosa Roscoe, no Estado de Minas Gerais, vencedoras da concorrência pública (SEMAE, 2002). 


\section{Particularidades do Sistema Combinado de Tratamento de Esgotos Sanitários: Reator Anaeróbio (UASB) Seguido de Reator Aeróbio (Lodos Ativados)}

\subsection{Definições Preliminares}

As estações de tratamento de esgotos em geral são constituídas de diversas unidades, usualmente na forma de tanques, cada qual desempenhando isoladamente uma ou mais funções específicas. Entretanto, cada unidade é operada de maneira integrada com as demais, formando um sistema de tratamento para atingir o objetivo comum que é a remoção de determinados constituintes do esgoto, principalmente para a recuperação da qualidade da água

A natureza dos constituintes no esgoto, bem como o grau de remoção desejada de cada um, são elementos básicos para definir os métodos de tratamento.

O tratamento de esgoto efetuado nas ETEs, é uma imitação dos fenômenos que ocorrem na natureza, sendo que a diferença é que em uma estação, este tratamento pode ser realizado sob condições controladas, em periodo de tempo menor e sem a maioria dos incovenientes sanitários e ambientais que ocorrem quando o esgoto é lançado "in natura".

Os métodos de tratamento fazem uso desses fenômenos, classificados como operações (fenômenos físicos) e processos unitários (fenômenos químicos ou biológicos). Exemplo de operação unitária é o que ocorre em tanques, bacias ou lagos de sedimentação e caixas de areia, onde não ocorrem reações ou transformações que modifiquem a natureza 
do material (lodo ou areia). Já como exemplo de processos unitários, têm-se os reatores químicos ou biológicos.

Os reatores químicos caracterizam-se por reações que ocorrem predominantemente entre substâncias químicas diferentes, existentes nos esgotos ou adicionadas nos tanques. Já nos reatores biológicos, tais reações químicas ocorrem com a interferência de microrganismos, os quais participam ativamente no decréscimo da concentração da matéria orgânica. Os constituintes do esgoto afluente são o alimento dos microrganismos, que os processam para o seu metabolismo por meio de reações diversas, resultando ao final um efluente mais clarificado e com menores concentrações, às vezes subprodutos, como gases dissolvidos e lodo biológico, que devem ser separados do líquido.

Os reatores biológicos podem ser classificados basicamente em dois tipos:

- $\quad$ reatores aeróbios - em função das bactérias que necessitam de oxigênio (livre ou molecular) dissolvido no meio para o seu metabolismo, deve haver alguma forma de aeração, artificial ou natural, para processar a matéria orgânica.

- reatores anaeróbios - deve haver ausência de oxigênio, devido à presença de bactérias anaeróbias; estas processam a matéria orgânica somente nessas condições, uma vez que o oxigênio livre é na maioria das vezes, um potencial tóxico, inibindo ou impedindo as suas atividades metabólicas.

Os reatores biológicos se constituem nas principais unidades de uma $E T E$, embora isotadamente não atendam à totalidade dos requisitos para a remoção de todos os constituintes dos esgotos. Dai a necessidade de um arranjo com outras unidades para funções especificas. Aos reatores biológicos cabe primordialmente a remoção da matéria orgânica particulada ou dissolvida. Entretanto, muitas vezes um único tipo de reator biológico não 
atende aos padrões de qualidade para o efluente, no tocante à remoção da matéria orgânica. Adicionalmente, outros constituintes, como os nutrientes (nitrogênio e fósforo, principalmente) e os organismos patogênicos, via de regra, são removidos de maneira não significativa.

Daí a necessidade, muitas vezes, de combinação de reatores biológicos com diferentes configurações para atender aos requisitos de qualidade do efluente, o que usualmente se tem denominado de sistemas combinados para polimento ou pós-tratamento dos esgotos. Deve-se ressaltar que os sistemas de tratamento somente com reator biológico anaeróbio podem atender, ao menos no tocante à remoção da matéria orgânica, aos requisitos para muitas situações. Independente disso, os sistemas combinados que incorporam os reatores anaeróbios como uma das unidades são alternativas que se apresentam atrativas, pelos seus diversos aspectos favoráveis, como a simplicidade de projeto e operação, uso de equipamentos não sofisticados, menos produção de lodo de excesso para disposição, baixo consumo de energia e de outros custos, menor área necessária, etc. (CAMPOS et al., 1999).

\subsection{Reator Anaeróbio Seguido de Reator Aeróbio}

O uso combinado de reatores anaeróbios e aeróbios apresenta-se com grande potencial para o polimento ou pós-tratamento de esgotos, incluindo não somente 0 tratamento complementar da matéria orgânica, como também para a remoção de outros poluentes, quando necessários. Em linhas gerais, quando se faz necessário obter um eftuente com alta qualidade, os processos aeróbios podem ser utilizados por suas conhecidas características e vantagens para a remoção de matéria orgânica com baixas concentrações. A maior parte da remoção caberia ao reator anaeróbio, ficando o remanescente para o reator aeróbio. Este porém teria reduzido 
significativamente as desvantagens atribuidas por causa dos menores custos de energia, volume do tanque e produção de lodo de excesso, e consequentemente, do conjunto reator anaeróbio-reator aeróbio (CAMPOS et al., 4999).

Existe um consenso de que, na maioria das aplicações, os sistemas anaeróbios devem ser encarados como uma primeira etapa do tratamento, uma vez que estes não são capazes de produzir efluentes finais com elevado grau de qualidade. Obviamente que em algumas situações, dependendo das características do despejo aftuente e dos requisitos de qualidade do lançamento final, os sistemas anaeróbios podem se constituir em uma etapa completa de tratamento. Entretanto, via de regra tem se buscado a utilização de sistemas combinados de tratamento, procurando-se obter as enormes vantagens de incorporação de um sistema anaeróbio como primeiro estágio de tratamento, seguido de uma unidade de póstratamento aeróbio (CHERNICARO, 1997).

Os sistemas anaeróbio e aeróbio combinados, que se apresentam com grandes possibilidades para o seu emprego na prática, são aqueles que utilizam o reator UASB como primeira etapa e, para a segunda etapa, os reatores de lodos ativados, convencional e suas variantes, e os reatores conhecidos como filtros biológicos (aeróbios) convencionais. Embora seja limitada a experiência no Brasil, nos países nos quais é exigida uma qualidade de efluente mais restritiva, seja para esgotos industriais ou domésticos, tem sido usual o emprego desses reatores, principalmente os de lodos ativados para o pós-tratamento. O uso de reatores UASB e lodos ativados pode ser justificado também pela maior experiência e targo emprego de ambos individualmente. Uma variante de lodo ativado empregada em escala real para efluente de UASB é a lagoa aerada (CAMPOS et al. 1999). 


\subsubsection{Reator UASB}

Embora com várias denominações no Brasil (RAFA, DAFA, RAFAALL, RALF, etc.), este reator se consagrou no mundo todo como UASB (upflow anaerobic sludge blanket), nomenclatura original dada em inglês por um de seus pioneiros na Holanda (LETTINGA et al., 1983), que passou a ser adotada também no Brasil (CAMPOS et al., 1999).

O UASB foi desenvolvido na década de 70 pelo Professor Lettinga e sua equipe na Universidade de Wageningen - Holanda e tem sido amplamente utilizado desde então (VAN HAANDEL \& LETTINGA, 1994).

O reator anaeróbio de manta de lodo é uma unidade de fluxo ascendente que possibilita o transporte das águas residuárias (esgotos) através de uma região que apresenta elevada concentração de microrganismos anaeróbios.

Esse reator deve ter seu aftuente criteriosamente distribuido junto ao fundo, de maneira que ocorra o contato adequado entre os microrganismos e o substrato (impurezas que alimentarão as bactérias). A agitação e a mistura são promovidas pelo escoamento do líquido assim como pelo movimento das bolhas de gases produzidas. Acima da região em que ocorrem a manta de lodo e o leito de lodo, existe uma região com dispositivos destinados à sedimentação de sólidos e à separação de gases

As experiências com o uso desse reator para o tratamento de esgotos demonstram sua grande potencialidade, para emprego intensivo com custos de operação significativamente inferiores em relação àquele correspondentes a sistemas de tratamento aeróbios convencionais. Os reatores de manta de lodo não necessitam de qualquer equipamento especial para seu funcionamento, resultando em consumo de energia (CAMPOS, 1992).

A FIGURA 6.1 traz a representação esquemática de um reator anaeróbio de manta de lodo com fluxo ascendente - reator UASB. 
FIGURA 6.1 - Representação esquemática de um reator UASB

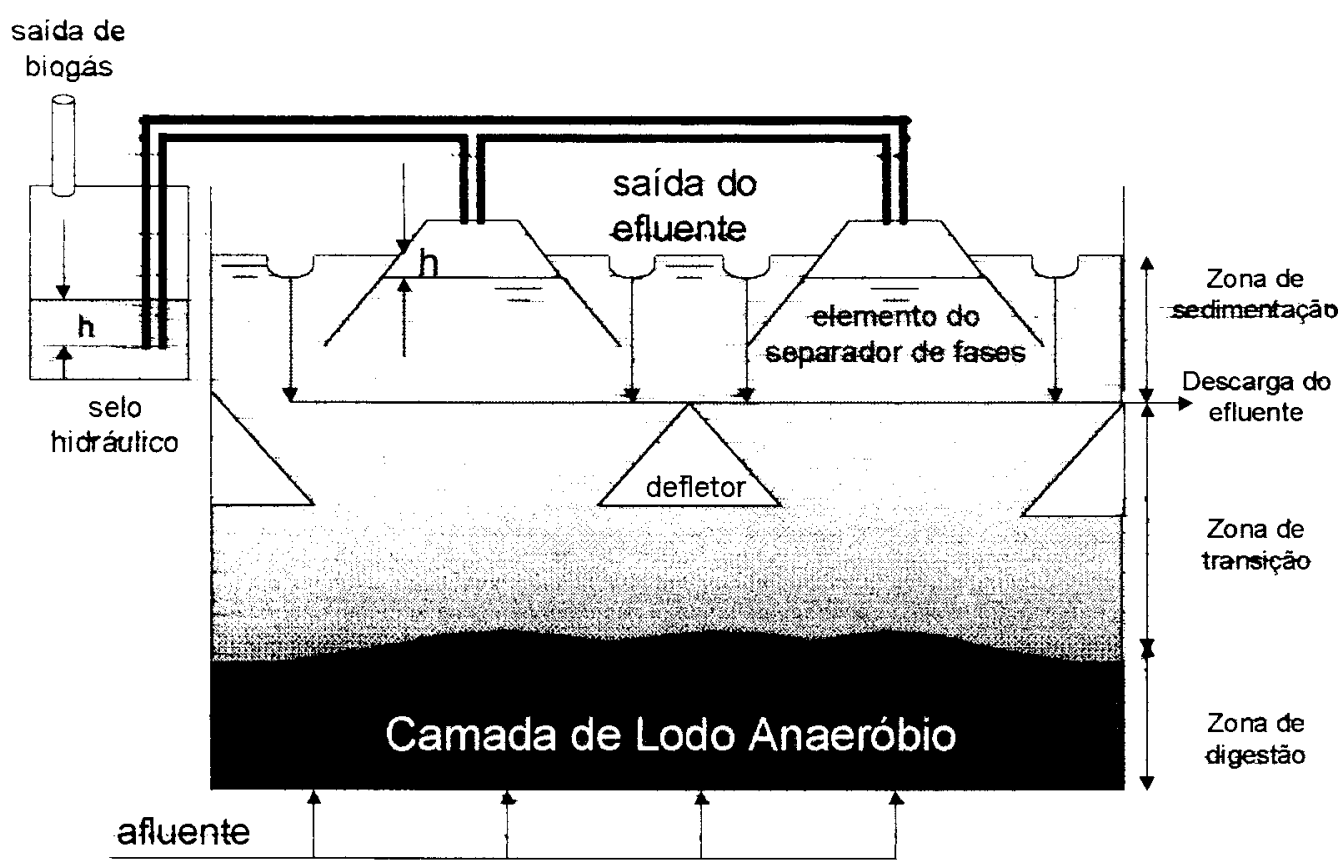

Fonte: VAN HAANDEL \& LETTINGA, 1994.

Dentre as vantagens do sistema UASB, encontram-se:

- $\quad$ satisfatória eficiência na remoção de DBO;

- baixos requisitos de área;-

- baixos custos de implantação e operação;

- $\quad$ reduzido consumo de energia;

- $\quad$ não necessita de meio suporte;

- construção, operação e manutenção simples;

- baixissima produção de lodo;

- $\quad$ estabilização do lodo no próprio reator; 
- necessidade apenas da disposição final do lodo;

- $\quad$ rápido reinício após períodos de paralisação.

Entre as desvantagens, pode-se citar:

- dificuldade em satisfazer padrões de lançamento bem restritivos;

- $\quad$ efluente com aspecto desagradável;

- $\quad$ remoção de nitrogênio $(N)$ e fósforo $(P)$ insatisfatória;

- possibilidade de maus odores;

- $\quad$ a granulação da biomassa pode ser difícil;

- a partida do processo é geralmente lenta,

- relativamente sensivel a variações de carga;

- restrito ao tratamento de afluentes com baixas concentrações de sólidos (VON SPERLING, 1994).

\subsubsection{Lodos Ativados}

Nos sistemas de lodos ativados, o esgoto aftuente e o lodo ativado são intimamente misturados, agitados e aerados (em unidades chamadas de tanques ou lagoas de aeração), para logo após separar os lodos ativados do esgoto tratado (por sedimentação em decantadores). O lodo ativado separado retoma para o processo ou é retirado para tratamento específico ou destino final, enquanto o esgoto já tratado passa para o vertedor do decantador no qual já ocorreu a separação.

Lodo ativado é o floco produzido num esgoto bruto ou decantado pelo crescimento de bactérias ou outros organismos, na presença de oxigênio 
dissolvido, e acumulado em concentração suficiente graças ao retorno de outros flocos previamente formados.

As necessidades de oxigênio dos flocos são elevadas, sendo necessário suprir oxigênio ao processo, por absorção forçada da atmosfera ou por injeção de ar no meio líquido. A quantidade de floco, naturalmente presente, é relativamente pequena, sendo necessários um tempo muito longo e um volume de tanque muito grande para tornar efetivo o processo em condições naturais; por esta razão se mantém nos tanques de aeração uma concentração elevada de flocos, através do retorno contínuo do lodo do decantador secundário aos tanques de aeração (JORDÃO \& PESSÔA, 1995).

A FIGURA 6.2 apresenta o esquema de uma ETE convencional com lodos ativados.

FIGURA 6.2 - Esquema de ETE convencional com lodos ativados

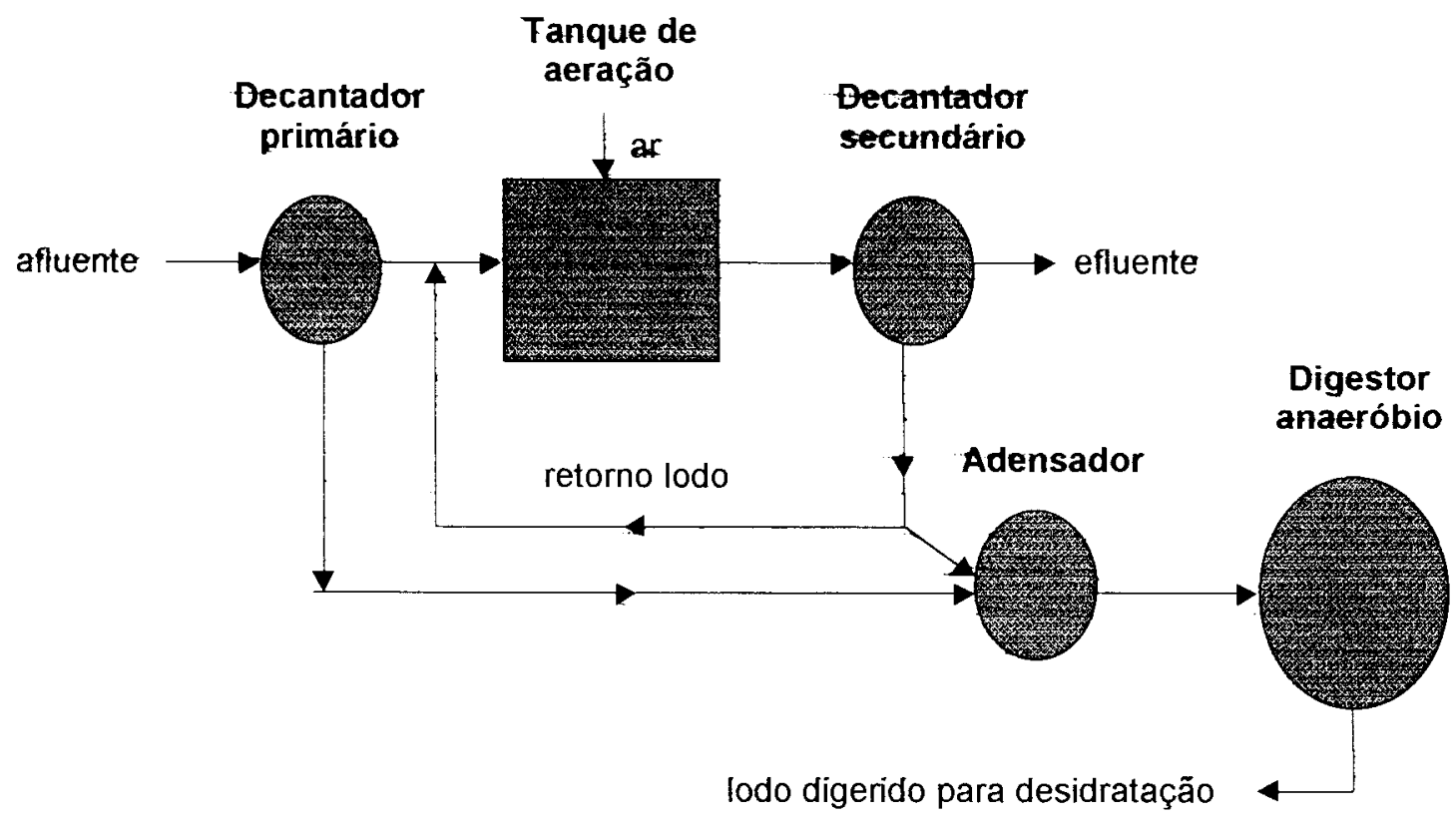

Fonte: ALÉM SOBRINHO, 2000 in BETHOL \& CAMARGO, 2000. 
O processo apresenta várias situações favoráveis à sua aplicação e algumas contrárias.

Como vantagens deste sistema, destacam-se:

- $\quad$ elevada eficiência na remoção de DBO (Demanda Biológica de Oxigênio);

- $\quad$ nitrificação usualmente obtida;

- possibilidade de remoção biológica de nitrogênio $(\mathrm{N})$ e fósforo (P) :

- $\quad$ baixos requisitos de área;

- $\quad$ processo confiável, desde que supervisionado;

- reduzidas possibilidades de maus odores, insetos e vermes.

Dentre as desvantagens, as principais são:

- $\quad$ elevados custos de implantação e operação;

- $\quad$ elevado consumo de energia;

- necessidade de operação sofisticada;

- $\quad$ elevado indice de mecanização;

- relativamente sensivel a descargas tóxicas;

- necessidade do tratamento completo do lodo e da sua disposição final;

- possíveis problemas ambientais com ruídos e aerossóis (VON SPERLING, 1994). 


\subsection{Vantagens Específicas do Sistema Combinado: UASB e Lodos Ativados}

Na FIGURA 6.3 encontra-se a representaçāo de um sistema combinado reator UASB seguido de lodos ativados, como o que se tem na ETE - Piracicamirim (objeto de estudo deste trabaho).

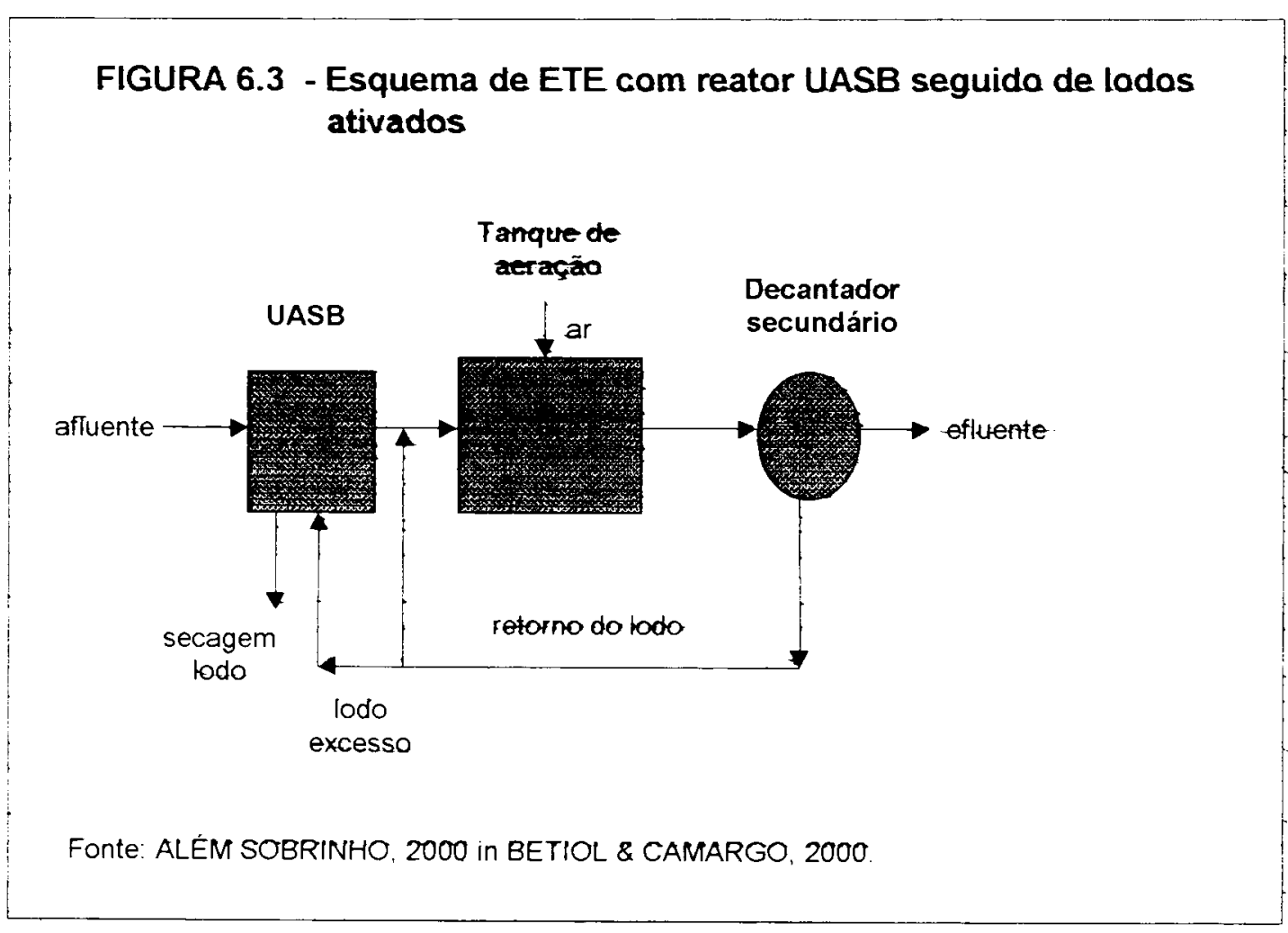

O uso combinado de reatores UASB e lodos ativados apresenta as seguintes vantagens quando comparado com um sistema somente aeróbio:

- $\quad$ volume total dos tanques do sistema combinado reduzido pela metade ou menos, devido à diminuição significativa da quantidade de matéria orgânica e sólidos suspenso no UASB; 
- não necessidade de um digestor exclusivo para o lodo de excesso aeróbio, que pode ser efetuado no próprio UASB;

- menor demanda de oxigênio e energia para o tanque aeróbio, devido à menor carga orgânica no tanque aeróbio e havendo possibilidade de produção de energia suficiente pelo biogás; $e$

- não necessidade de dimensionar os aeradores pela demanda máxima de oxigênio, devido ao papel de equalização do UASB (VAN HAANDEL \& LETTINGA, 1994; CAMPOS et at., 1999).

Estas vantagens são bastante claras e suficientes para justificar o prétratamento anaeróbio de esgoto antes de tratamento em um sistema de lodos ativados, ao menos quando se tem o tratamento em nivel secundário tratamento biológico - como objetivo (VAN HAANDEL \& LETTINGA, 1994). 


\section{Metodologia para Avaliação do Impacto da Proliferação de Odores Ofensivos do Tratamento de Esgotos Sanitários}

O objetivo deste trabalho, como salientado no capítulo 1, constituiu-se na avaliação do impacto da proliferação de odores ofensivos decorrentes da operação da ETE - Piracicamirim, em Piracicaba - SP, por meio da análise da percepção da população vizinha, situada na área compreendida pelo raio de $1 \mathrm{Km}$, a partir da estação.

A hipótese a ser verificada, foi de que a proliferação de odores ofensivos decorrente da operação da ETE - Piracicamirim, em Piracicaba $\mathrm{SP}$, repercutia negativamente sobre a saúde e o bem estar da população vizinha.

A modalidade do estudo científico empreendido, por seu caráter exploratório, permite classificá-lo como um "estudo descritivo", ou seja, aquele cujo objetivo consiste em caraterizar o problema sem a pretensão imediata de solucioná-lo (USP-FSP, 1998).

Apesar de seu enfoque qualitativo, evidenciado por tratar-se de uma análise da percepção popular referente a um problema especifico, a utilização do questionário como instrumento de pesquisa, associou um aspecto quantitativo ao estudo.

O trabalho que ofereceu subsidios e despertou o interesse para a realização do estudo apresentado por esta tese, corresponde à dissertação de mestrado "Avaliação dos Impactos Sociais nos Processos de Implantação e Gestão dos Serviços de Tratamento de Esgotos Sanitários", desenvolvida junto ao Departamento de Engenharia Civil da Universidade Federal de São Carlos (DECiv-UFSCar), onde apurou-se que a proliferação de odores 
ofensivos do tratamento de esgotos consistia na principal queixa dos moradores circunvizinhos às ETEs (DE SOUZA, 1998).

Portanto, no doutorado optou-se por abordar o impacto que sobressaiu-se na pesquisa anterior, como sendo o de maior e pior repercussão entre os vizinhos de ETEs, ou seja, a proliferação de odores ofensivos decorrente do tratamento de esgotos sanitários.

Ë importante ressaltar, que no processo de delimitação do tema de pesquisa, do objeto de estudo e dos métodos de trabalho a serem utilizados, ocorreram algumas modificações em relação ao projeto de pesquisa originalmente proposto no exame de qualificação.

Estas mudanças, decorrentes do confronto entre a proposta inicial e as condições reais para a execução da pesquisa, resultaram nos procedimentos finalmente adotados e que serão apresentados neste capitulo.

\subsection{Eleição do Objeto de Estudo de Caso}

A Região da Bacia do Rio Piracicaba, por sua importância econômica e social no cenário nacional, e ainda, por seu pioneirismo no combate à degradação dos recursos hidricos, já havia sido previamente escothida como objeto de estudo.

A principio, pretendia-se eleger duas ou três estações de tratamento de esgotos, onde seriam realizados os estudos de caso, para posteriores comparações de resultados. Entretanto, optou-se por um único objeto de estudo de caso, a saber, a ETE - Piracicamirim, em Piracicaba - SP. 
Esta opção deveu-se ao fato, constatado em campo, da complexidade da questão, envolvendo de um lado a estação e do outro os vizinhos insatisfeitos com a produção dos maus odores.

Esperava-se realmente encontrar ETEs com potencial e mesmo com relatos de proliferação de odores ofensivos, todavia, o quadro apresentado pela ETE - Piracicamirim, ultrapassou todas as expectativas iniciais, chamando a atenção para a necessidade de um estudo mais completo e abrangente

Assim, sacrificou-se a possibilidade de um estudo comparativo (mesmo porque, seria bastante difícil estabelecer critérios de comparação entre estações de porte e sistemas de tratamento diferentes), por um estudo mais detalhado de um único, porém relevante caso de proliferação de odores decorrentes do tratamento de esgotos sanitários.

\subsection{Reestruturação da Metodologia de Trabalho}

A metodologia primeiramente definida para a pesquisa, contemplava duas frentes de trabalho que se julgavam comptementares, a saber: a investigação através de questionário ("checklist") e a análise olfatométrica empregando-se o conceito de "painel de odor".

Entretanto, por motivos de ordem econômica (preço de ampolas para - laboratório, principatmente) e por razões conceituais que serão discutidas adiante, a realização desta segunda etapa proposta no projeto inicial olfatometria - mostrou-se inviável.

Assim, buscou-se em contrapartida, dar a este trabalho um enfoque mais qualitativo voltado à percepção popular do impacto da proliferação de odores ofensivos de uma ETE, do que um enfoque laboratorial ou de medição de odor, propriamente dito 


\subsubsection{Método Preterido: Olfatometria}

$\mathrm{Na}$ análise de compostos odorantes, entre eles os odores ofensivos do tratamento de esgotos sanitários, podem ser adotadas três tipos de medidas

1. Determinação físico-quimica;

II. Determinação olfatométrica;

III. Nariz eletrônico.

Os métodos físico-químicos para análise dos compostos odorantes permitem a identificação da impressão digital do odor, ou seja, identificar os produtos quimicos da mistura gasosa. Na quantificação e qualificação dos compostos, a técnica analítica mais apropriada é a cromatografia gasosa, podendo estar acoplada a uma unidade de desorção térmica e outra de espectometria de massa

A olfatometria fundamenta-se na importância das mucosas olfativas, como os únicos captores disponiveis para a avaliação dos odores. Nestes estudos o detector de avaliação dos odores é o sistema olfativo do ser humano, encarregando-se de discriminar e identificar os corpos odorantes. Em muitas situações somente a anátise olfatométrica é suficiente para a avaliação dos incômodos provenientes de emissões com maus odores. Isto vem ocorrendo em vários países, tais como Canadá, Bélgica, Holanda e França, onde esta metodologia está sendo disseminada para avaliação do conforto ambiental, tendo como principio que somente o ser humano pode dizer se uma amostra gasosa é odorante ou não.

O conceito de nariz eletrônico utiliza uma rede de sensores gasosos não seletivos que simulam os receptores biológicos do nariz humano. Os sinais emitidos pelos sensores permitem associar uma forma caracteristica ou assinatura espectral a um determinado odor. 
Dos três tipos de medidas apresentados, tem-se que a olfatometria apresenta maiores vantagens de aplicação, uma vez que as mais finas análises por cromatografia gasosa e espectometria de massa (métodos físico-químicos) não pođem rivalizar com o aparelho olfativo humano e que apesar das vantagens do nariz eletrônico, seu uso continua bastante seletivo e restrito a aplicações industriais, principalmente na indústria de alimentos (BELLI FILHO \& DE MELO LISBOA, 1998).

$\mathrm{Na}$ análise dos odores do tratamento de esgotos mediante o uso de técnicas olfatométricas, pretendia-se empregar o conceito de painel de odor, que nada mais é, do que a composição de um júri de pessoas treinadas e selecionadas de uma população para avaliar uma atmosfera com odores. Nesta avaliação, poderiam ser determinados limites referentes à percepção, à caracterização e à identificação olfativas, bem como a intensidade odorante de uma atmosfera, tudo isso mediante o tratamento estatístico das várias respostas dos painelistas (júri).

$\mathrm{Na}$ composição do painel de odor, contemplava-se a possibilidade do envolvimento das populações vizinhas nos processos de formação e atuação do júri. Os painelistas receberiam treinamento em laboratório, através da simulação de atmosferas com e sem presença de sulfetos, para depois a verificação das condições "in loco", ou seja, nas proximidades da estação.

Entretanto, para estas simulações em laboratório, seriam necessárias certas ampolas odoríficas importadas e de alto valor comercial. Contatos foram feitos no sentido de localizar laboratórios interessados em patrocinar esta etapa da pesquisa, contudo tais esforços não lograram êxito.

Até mesmo, chegou-se a cogitar a possibilidade de utilização de um "kit" japonês para análise sensorial de odor de propriedade da CETESB, todavia o laboratório em que o mesmo se encontrava estava em processo de fechamento e as pessoas que conheciam o equipamento foram transferidas para outras unidades do órgão. 
Além de todos as dificuldades expostas, outro fator que motivou o abandono desta abordagem metodológica diz respeito à literatura especializada que aponta para os problemas práticos do emprego das técnicas olfatométricas, já que a sensação olfativa, que resulta da interação de um determinado número de moléculas odorantes com a mucosa olfativa varia não apenas de um indivíduo a outro, mas também, para um mesmo indivíduo, em função de seu estado fisiológico (PERRIN, 1994; McGINLEY \& MCGINLEY, 1997; BELLI FILHO \& DE MELO LISBOA, 1998).

\subsubsection{Método Utilizado: Questionário (Checklist)}

O instrumento de trabalho conhecido como listagem de controle ou por sua denominação em inglês "checklist", corresponde a um dos muitos métodos existentes para a Avaliação de Impacto Ambiental - AIA (UNEP \& UNESCO, 1975; BISSET, 1980; BOLEA, 1984).

Existem vários tipos de listagens de controle, compreendendo listas de ações ou atividades impactantes, de fatores ou componentes ambientais e de parâmetros ou indicadores ambientais, que associados permitem identificar e caracterizar os impactos mais relevantes (SALVADOR, 1989; MAIA, 1992).

Neste trabalho, a listagem de controle utilizada corresponde ao tipo "listagem em questionário".

Geralmente, os questionários cumprem ao menos duas funções: descrever as características e medir determinadas variáveis de um grupo social (no caso a população vizinha à ETE - Piracicamirim).

Quanto ao tipo, os questionários podem ser classificados da seguinte forma:

- Pelo tipo de pergunta feita ao entrevistado: 
- Questionário de perguntas fechadas (objetivas);

- Questionário de perguntas abertas (subjetivas);

- Questionário que combina ambos os tipos de perguntas.

Pelo modo de aplicação do questionário:

- Contato direto - o entrevistador vai até o entrevistado;

- Questionário enviado pelo correio - também chamado de formulário (RICHARDSON, et al., 1985).

O questionário para a avaliação da repercussão de odores decorrentes de estações de tratamentos de esgotos sobre as populações circunvizinhas (ANEXO 1), é do tipo de perguntas fechadas, sendo o modo de aplicação o contato direto.

As principais vantagens da adoção de um questionário de perguntas fechadas dizem respeito à:

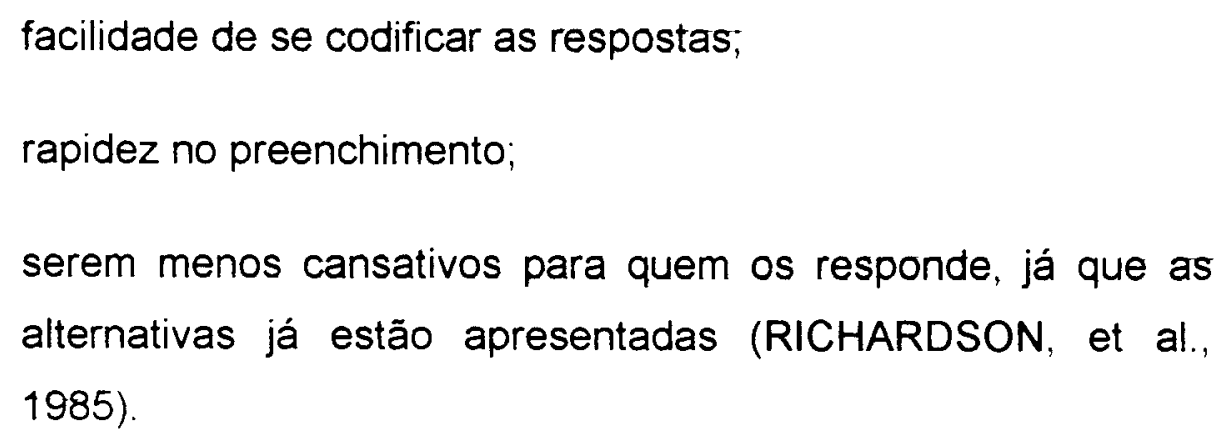

Para o levantamento das informações necessárias para a análise da percepção popular acerca do impacto da proliferação de odores ofensivos do tratamento de esgotos sanitários, foi elaborado um questionário composto de 38 questões objetivas, divididas nos seguintes itens:

I. Identificação - 7 questões referentes a(o):

Município / Data / Nome do entrevistado / Sexo / Idade / Endereço / Posição na Estrutura Familiar. 
II. Condições sócio-econômicas - 3 questões referentes a(o):

Forma de apropriação do imóvel / Número de pessoas residentes no imóvel - Renda familiar / Escolaridade do entrevistado.

III. Estrutura domicitiar e urbanidade - 11 questões referentes $a(0)$ :

Tempo de moradia no imóvel / Procedência da familia (urbana ou rural) / Procedência da família (município de origem) / Motivo da vinda para Piracicaba / Indicação dos aspectos locais (clima, qualidade do ar, proximidade do local de trabalho, de escolas, igreja, comércio) / Qualidade dos serviços urbanos (água, esgoto, pavimentação, limpeza pública, coleta de lixo, iluminação pública, transporte coletivo) / Localização do imóvel em relação à outras fontes potenciais de incômodos (cemitério, lixão, aterro sanitário, usina de açúcar ou de álcool, indústrias) I Informações sobre o imóvel domiciliar / Bens de consumo existentes no imóvel / Consumo de água potável / Ligações domiciliares de água e esgoto.

IV. Avaliação em relação às questões ligadas às empresas de saneamento e ao tratamento de esgotos - 8 questões referentes a(o):

Conhecimento acerca da empresa de saneamento I Classificação dos serviços gerais prestados pela empresa / Opinião acerca das tarifas de saneamento / Percepção em relação ao problema do esgoto / Conhecimento do destino do esgoto doméstico / Impactos relacionados à ETE / Atuação da empresa de saneamento em relação aos impactos / Memória acerca da ocupação anterior da área onde está a ETE. 
V. Nivel de interferência dos odores da ETE na vida pessoal e social da vizinhança - 4 questões referente $a(0)$ :

Presença dos odores / Frequência dos odores / Percepção de fatores agravantes / Restrições ocasionadas pela presença dos maus odores.

\section{Estrutura política-cultural}

Participação em associações comunitárias / Área de atuação das associações / Avaliação dos resultados alcançados pelas associaçōes / Perfil político do entrevistado / Classificação econômica que o entrevistado atribui a si próprio.

Este questionário tomou como modelo o formato de questionário apresentado em DE SOUZA, 1998, no qual as questões relacionadas ao tratamento de esgotos e seus impactos (entre eles a proliferação de odores ofensivos), são avaliadas em conjunto com a conscientização ambiental dos entrevistados e seu conhecimento acerca da empresa de saneamento que os servem.

Os operadores da estação de tratamento de esgotos, não constituíram parte da população entrevistada, por apresentarem relação trabathista com o órgão de saneamento responsável pela ETE, O que poderia comprometer seus depoimentos.

Para as entrevistas adotou-se o seguinte critério (DE SOUZA, 1998):

Fixação de um raio de $1 \mathrm{Km}$ ao redor da estação;

Estimação do número de unidades residenciais compreendidas peto raio (através de mapas de loteamentos e verificação "in loco");

Amostragem aleatória (sorteio) das unidades a serem visitadas;

Coleta de informações utilizando o questionário 
As entrevistas foram realizadas em finais de semana (sábados e domingos) e feriados, quando encontra-se mais facilmente os moradores em suas casas, existindo também uma maior disponibilidade de tempo por parte dos entrevistados, o qual durante os dias úteis costuma ser ocupado em tarefas de trabalho, domésticas e escolares.

Quando da abordagem dos entrevistados, foram dadas informações referentes à pesquisa, objetivo e procedência, além da distribuição do "Termo de Consentimento Livre e Esclarecido" (ANEXO 2).

Foram respeitados os indivíduos, que por qualquer motivo, preferiram não responder ao questionário, tomando-se então a residência imediatamente seguinte à direita daquela sorteada, para uma nova tentativa.

Também em caso de lote vago, ou residência fechada (ausência de moradores), foi tomada a residência mais próxima àquela sorteada, para a entrevista.

Aos entrevistados garantiu-se a manutenção de sua identidade em anonimato, quando da publicação dos resultados da pesquisa, para que pudessem responder livremente às questões, sem medo de ficarem expostos à críticas ou represálias de quaisquer ordem ou procedência.

\subsection{Critérios de Amostragem}

Para a determinação de uma amostra representativa da população circunvizinha à ETE - Piracicamirim, foram adotados os seguintes critérios de amostragem (RICHARDSON et al., 1985):

1. Elementos do Universo considerados: residências vizinhas à estação. 
Adotou-se como elementos do universo para amostragem, as residências localizadas no entorno da estação (raio de $\uparrow \mathrm{Km}$ ), para que pudessem ser estudadas as unidades familiares sujeitas ao impacto da proliferação de odores ofensivos do tratamento de esgotos sanitários.

2. Amplitude do universo: finito.

Com respeito à amplitude, o universo da amostra divide-se em finito e infinito. Consideram-se universos finitos (limitados) aqueles que não ultrapassam 100.000 unidades e infinitos os que ultrapassam tal número. Esta distinção é importante para determinar o tamanho da amostra, uma vez que as fórmulas empregadas são diferentes para universos finitos e infinitos.

3. Tipo de amostra: aleatória.

Para que uma amostra seja considerada aleatória, os elementos da população devem ter uma probabilidade igual ou conhecida, distinta de zero, de serem selecionados ao acaso para formar parte da amostra.

4. Nivel de confiança estabelecido: $95,5 \%$.

Adotado usualmente em pesquisas sociais, o nivel de confiança equivatente a $95,5 \%$ corresponde a uma probabilidade de 95,5 em 100 , de que qualquer resultado obtido na amostra seja válido para o universo.

5. Erro de estimação permitido: $\pm 10 \%$.

Os resultados da amostra não podem ser rigorosamente exatos em relação ao universo que pretendem representar; supõem erros de medição. Evidentemente, esses erros diminuem à medida que o tamanho da amostra aumenta. 
Geralmente, nas pesquisas sociais, não se aceita um erro maior que $6 \%$. Contudo, como esta pesquisa não tem a pretensão de entitular-se uma pesquisa social com todas as suas prerrogativas e características, foi adotado um erro de estimação permitido de $10 \%$, considerado apropriado para a análise da percepção popular acerca do impacto da proliferação de odores ofensivos do tratamento de esgotos sanitários.

6. Estimativa da proporção que a característica pesquisada representa no universo: $50 \%$.

Consiste na estimação prévia da proporção que a característica pesquisada representa no universo. Apenas para exemplificar, suponha-se que em uma pesquisa se deseja conhecer a atitude dos estudantes da USP em relação às suas experiências profissionais anteriores ao seu ingresso na universidade, estima-se previamente a proporção de alunos que tiveram esse tipo de experiência. Geralmente, a determinação exata deste fator é bastante complexa; sendo assim, o que usualmente se faz é supor que a proporção da característica pesquisada no universo é de $50 \%$, o caso mais desfavorável para a estimação, pois, é aquele em que a amostra deve ser maior.

\subsection{Determinação da Amostra}

Definidos os critérios de amostragem e reatizada a estimativa do número de lotes residenciais compreendidos pelo raio de $1 \mathrm{Km}$ ao redor da estação, tornou-se possivel a determinação da amostra para a aplicação do questionário, fazendo-se uso da Tabela 7.1, apresentada a seguir: 
TABELA 7.1 - Determinação de uma amostra de populações finitas, para $p=$ $50 \%$ e os erros de estimaçăo indicados (nivel de confiança de $95,5 \%$ )

\begin{tabular}{|c|c|c|c|c|c|c|c|}
\hline & \multirow{2}{*}{$\begin{array}{l}\text { AMPLITUDE DA } \\
\text { POPULAÇÃO }\end{array}$} & \multicolumn{6}{|c|}{ TAMANHO DA AMOSTRA PARA OS ERROS INDICADOS } \\
\hline & & $\pm 1 \%$ & $\pm 2 \%$ & $\pm 3 \%$ & $\pm 4 \%$ & $\pm 5 \%$ & $\pm 10 \%$ \\
\hline 500 & $\ldots \ldots \ldots \ldots \ldots \ldots$ & & & & & 222 & 83 \\
\hline 1.000 & $\ldots \ldots \ldots \ldots \ldots \ldots \ldots$ & & & & 385 & 286 & 92 \\
\hline 1.500 & $\ldots \ldots \ldots \ldots \ldots \ldots \ldots \ldots \ldots$ & & & 638 & 441 & 316 & 94 \\
\hline 2.000 & $\ldots \ldots \ldots \ldots \ldots \ldots \ldots \ldots \ldots$ & & & 714 & 476 & 333 & 95 \\
\hline 2.500 & $\ldots \ldots \ldots \ldots \ldots \ldots \ldots \ldots \ldots \ldots$ & & 1.250 & 769 & 500 & 345 & 96 \\
\hline 3.000 & $\ldots \ldots \ldots \ldots \ldots \ldots \ldots \ldots \ldots$ & & 1.364 & 811 & 517 & 353 & 97 \\
\hline 3.500 & $\ldots \ldots \ldots \ldots \ldots \ldots \ldots \ldots \ldots$ & & 1.458 & 843 & 530 & 359 & 97 \\
\hline 4.000 & $\ldots \ldots \ldots \ldots \ldots \ldots \ldots \ldots \ldots$ & & 1.538 & 870 & 541 & 364 & 98 \\
\hline 4.500 & $\ldots \ldots \ldots \ldots \ldots \ldots \ldots \ldots \ldots$ & & 1.607 & 891 & 549 & 367 & 98 \\
\hline 5.000 & $\ldots \ldots \ldots \ldots \ldots \ldots \ldots \ldots \ldots$ & & 1.667 & 909 & 556 & 370 & 98 \\
\hline 6.000 & $\ldots \ldots \ldots \ldots \ldots \ldots \ldots \ldots \ldots$ & & 1.765 & 938 & 566 & 375 & 98 \\
\hline 7.000 & $\ldots \ldots \ldots \ldots \ldots \ldots \ldots \ldots \ldots$ & & 1.842 & 949 & 574 & 378 & 99 \\
\hline 8.000 & $\ldots \ldots \ldots \ldots \ldots \ldots \ldots \ldots \ldots$ & & 1.905 & 976 & 580 & 381 & 99 \\
\hline 9.000 & $\ldots \ldots \ldots \ldots \ldots \ldots \ldots \ldots \ldots$ & & 1.957 & 989 & 584 & 383 & 99 \\
\hline 10.000 & 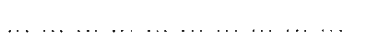 & 5.000 & 2.000 & 1.000 & 588 & 385 & 99 \\
\hline 15.000 & $\ldots \ldots \ldots \ldots \ldots \ldots \ldots \ldots$ & 6.000 & 2.143 & 1.034 & 600 & 390 & 99 \\
\hline 20.000 & $\ldots \ldots \ldots \ldots \ldots \ldots \ldots \ldots$ & 6.667 & 2.222 & 1.053 & 606 & 392 & 100 \\
\hline 25.000 & $\ldots \ldots \ldots \ldots \ldots \ldots \ldots \ldots$ & 7.143 & 2.273 & 1.064 & 610 & 394 & 100 \\
\hline 50.000 & $\ldots \ldots \ldots \ldots \ldots \ldots \ldots \ldots$ & 8.333 & 2.381 & 1.087 & 617 & 397 & 100 \\
\hline 100.000 & $\ldots \ldots \ldots \ldots \ldots \ldots \ldots \ldots$ & 9.091 & 2.439 & 1.099 & 621 & 398 & 100 \\
\hline & & 10.000 & 2.500 & 1.111 & 625 & 400 & 100 \\
\hline
\end{tabular}

Fonte: ARKIN. N. \& COLTON, R. apud RICHARDSON et al., 1985. 
Na estimativa do número de lotes ao redor da ETE - Piracicamirim, chegou-se ao vator de 666 unidades residenciais, que corresponde a amplitude do universo. Da Tabela 7.1 tem-se os seguintes valores:

$$
\begin{array}{lll}
\text { Para amplitude }=500 & \rightarrow & \text { amostra }=83 \\
\text { Para amplitude }=1.000 & \rightarrow & \text { amostra }=92
\end{array}
$$

Interpolando-se os valores da tabela, tem-se o seguinte valor aproximado:

$$
\text { Para amplitude }=666 \quad \rightarrow \quad \text { amostra }=86
$$

Assim sendo, o número de entrevistas foi fixado em 86 (oitenta e seis). $\mathrm{Na}$ escolha das residências a serem visitadas, respeitou-se o critério de aleatoriedade, com 0 sorteio das casas. Dois bairros foram compreendidos pelo raio de $1 \mathrm{Km}$ ao redor da ETE - Piracicamirim, sendo eles o Jardim Brasília e a Vila Independência.

A seguir serão apresentados os resultados obtidos com a aplicação do questionário e a análise dos mesmos. 


\section{Estudo de Caso: Análise dos Resultados da Pesquisa de Campo}

A aplicação do questionário desenvolvido para a pesquisa de campo (ANEXO 1), ocorreu durante os meses de setembro e outubro de 2000 e o tempo médio de duração de cada entrevista esteve em torno de 15 minutos.

Para uma melhor visualização das informações e dos dados coletados, foram desenvolvidas tabelas e gráficos com os resultados obtidos para cada questão proposta pelo questionário. Este material, ao qual denominou-se de "Dados Primários", encontra-se apresentado no ANEXO 3 , ao final desta tese.

A pesquisa de campo obteve uma vasta quantidade de dados $e$, dentre eles, optou-se por eleger algumas variáveis e indicadores considerados essenciais à compreensão do problema e que possibilitem atender ao objetivo desta pesquisa, que consiste na avaliação do impacto da proliferação de odores ofensivos decorrentes da operação da ETE Piracicamirim, em Piracicaba - SP, por intermédio da análise da percepção da população vizinha à estação.

As variáveis escolhidas para a análise dos resultados e as razões para sua escotha, foram as seguintes:

$\checkmark$ Variável 1 - Sexo dos entrevistados - verificar as diferenças relativas à percepção de homens e mulheres em relação ao tema enfocado

$\checkmark$ Variável 2 - Faixa etária dos entrevistados - como se comportam os diferentes grupos etários (jovens, adultos e idosos) em face aos indicadores apontados. 
$\checkmark$ Variável 3 - Renda familiar - averiguar se as diferenças nos padrões econômicos das famílias estudadas afetam sua percepção dos fatos e, em caso positivo, de que maneira isso ocorre.

$\checkmark$ Variável 4 - Escolaridade dos entrevistados - verificar até que ponto o nivel de escolaridade do individuo influencia em suas respostas.

$\checkmark$ Variável 5 - Procedência da Familia (cidade de origem) - estudar como se comportam "migrantes" e "não migrantes" em face aos indicadores considerados.

Os indicadores propostos para a análise e os motivos que levaram à sua eleição, são os que se seguem:

$\checkmark$ Indicador 1 - Conhecimento (ou não) do órgão de saneamento local - analisar o grau de reconhecimento da população em relação ao órgão responsável pelo serviço de tratamento de esgotos.

$\checkmark$ Indicador 2 - Opinião sobre a disposição dos esgotos - medir o grau de conscientização do entrevistado em relação ao problema do destino final dos esgotos sanitários.

$\checkmark$ Indicador 3 - Percepção do impacto da proliferação de odores ofensivos do tratamento de esgotos - avaliar a repercussão deste impacto sobre a população estudada.

$\checkmark$ Indicador 4 - Identificação da presença dos odores ao longo do ano - apontar quando os odores são percebidos durante o ano, ou seja, quais as "estações criticas", segundo os entrevistados.

$\checkmark$ Indicador 5 - Identificação da frequência dos odores ao longo do dia - verificar quais os períodos do dia em que os odores são sentidos 
$\checkmark$ Indicador 6 - Percepção de fatores agravantes - averiguar a existência de outras fontes de poluição que estejam agravando a questão dos odores, sob o ponto de vista da população atingida.

$\checkmark$ Indicador 7 - Reconhecimento de efeitos da exposição aos odores - apontar os efeitos que os entrevistados atribuem à interferência dos odores em sua vida pessoat e social.

Antes de analisar o comportamento das variáveis em face aos indicadores escolhidos, faz-se necessário uma análise pretiminar destes indicadores, que será apresentada a seguir.

\subsection{Indicadores da Percepção Popular}

Com base nas informações obtidas em campo, pode-se afirmar que os vizinhos da ETE - Piracicamirim, conhecem bem o órgão responsável pelo tratamento de esgotos em sua cidade - indicador 1, já que $79 \%$ dos entrevistados apontaram o SEMAE, como o órgão de saneamento local. Os demais $21 \%$ ficaram assim divididos: $20 \%$ não sabem qual é órgão responsável e $1 \%$ apontaram outro órgão.

Quanto à disposição de esgotos - indicador 2, as opiniões dividiramse da seguinte forma: $88 \%$ são favoráveis ao tratamento de esgotos; $1 \%$ afirmaram que as fossas seriam a melhor solução; $9 \%$ não souberam responder e $2 \%$ deram outras respostas. Estes percentuais são suficientes para afirmar que a população em estudo reconhece a importância do tratamento de esgotos.

A percepção do impacto da protiferação de odores ofensivos do tratamento de esgotos - indicador $\mathbf{3}$, é bastante significativa. Dos 86 entrevistados, 94\% (81 pessoas) queixaram-se de maus odores, contra apenas $6 \%$ ( 5 indivíduos) que nada tem a declarar a esse respeito. Mais 
uma vez fica demonstrada a relevância deste impacto e a necessidade de sua avaliação.

Em relação ao indicador 4 - identificação da presença dos odores ao longo do ano, $40 \%$ afirmaram que o mau cheiro está presente durante todo o ano, contra $34 \%$ que só o identificam nos meses quentes, $23 \%$ que afirmaram percebê-lo apenas ocasionalmente e $6 \%$ que nunca perceberam odor atgum.

Já quanto a identificação da frequência dos odores ao longo do dia indicador 5 , têm-se que $37 \%$ dos entrevistados queixaram-se de odores no periodo da tarde, contra $35 \%$ que apontaram o periodo da noite como o mais crítico, $10 \%$ que afirmaram que os odores estão presentes durante todo 0 dia, $7 \%$ que declaram que eles ocorrem em periodos diferenciados de acordo com as estações do ano e $6 \%$ que nunca identificaram odor algum relacionado à ETE.

A percepção de fatores agravantes - indicador 6 , não é muito precisa: apenas $1 \%$ dos entrevistados afirmaram que o problema dos maus odores é agravado por outras fontes de poluição, contra $40 \%$ que declaram que não haver interferência externa contribuindo para agravar o problema, $53 \%$ que não têm certeza quanto a este assunto e os $6 \%$ que continuaram afirmando não haver odor algum.

O reconhecimento dos efeitos da exposição aos odores - indicador 7 , é caracterizado pelos seguintes índices: $51 \%$ dos entrevistados declaram que já tiveram que fechar janelas e portas da residência em decorrência dos maus odores, $47 \%$ queixaram-se de efeitos os mais diversos, $41 \%$ afirmaram ter restrições na utilização de seus quintais e jardins devido ao problema, $23 \%$ queixaram-se de mau estar, $15 \%$ de doenças respiratórias e $3 \%$ afirmaram que compraram ventiladores por causa dos odores.

Após esta pré-análise dos indicadores da percepção popular, pode-se proceder à verificação do comportamento das variáveis frente aos mesmos. 


\subsection{Comportamento das Variáveis em Relação aos Indicadores}

\section{Variável 1 - Sexo dos Entrevistados}

Num total de 86 entrevistas, o número de mulheres participantes (47) foi um pouco maior que o de homens (39). Expressando esses valores em termos percentuais têm-se: $55 \%$ de mulheres contra $45 \%$ de homens entrevistados.

Percebe-se através destes números, que tanto mulheres quanto homens mostraram-se dispostos à colaborar com a pesquisa, respondendo ao questionário e dando seus depoimentos sobre a questão do impacto da proliferação de odores ofensivos relacionados à ETE - Piracicamirim.

Analisando o comportamento de homens e mulheres em relação ao indicador 1 - conhecimento (ou não) do órgão de saneamento local, foi possível a composição do gráfico apresentado na FIGURA 8.1.

FIGURA 8.1 - Sexo dos entrevistados X Conhecimento (ou não) do órgão responsávet
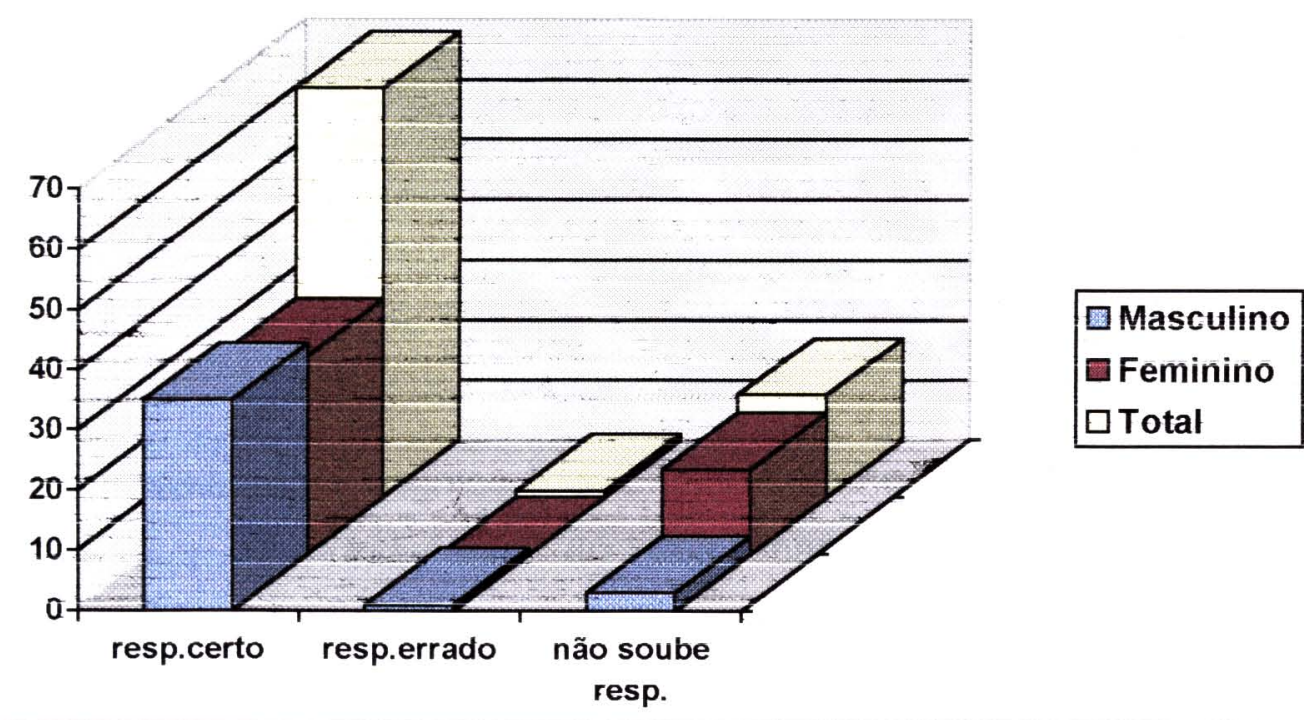
Observando o gráfico da FIGURA 8.1, pode-se afirmar que de uma maneira geral, tanto homens quanto mulheres conhecem bem o órgão de saneamento local, ou seja, o responsável pela estação de tratamento de esgatos.

$\mathrm{Na}$ análise das respostas obtidas, têm-se que os homens tiveram maior segurança ao apontar o SEMAE como o órgão de saneamento local do que as mulheres, já que $90 \%$ deles responderam corretamente contra $70 \%$ do público feminino entrevistado.

Em relação ao indicador 2 - opinião sobre a disposição dos esgotos, tem-se a FIGURA 8.2, expressando o que homens e mulheres afirmaram em suas respostas.

FIGURA 8.2 - Sexo dos entrevistados X Opinião sobre a disposição dos esgotos

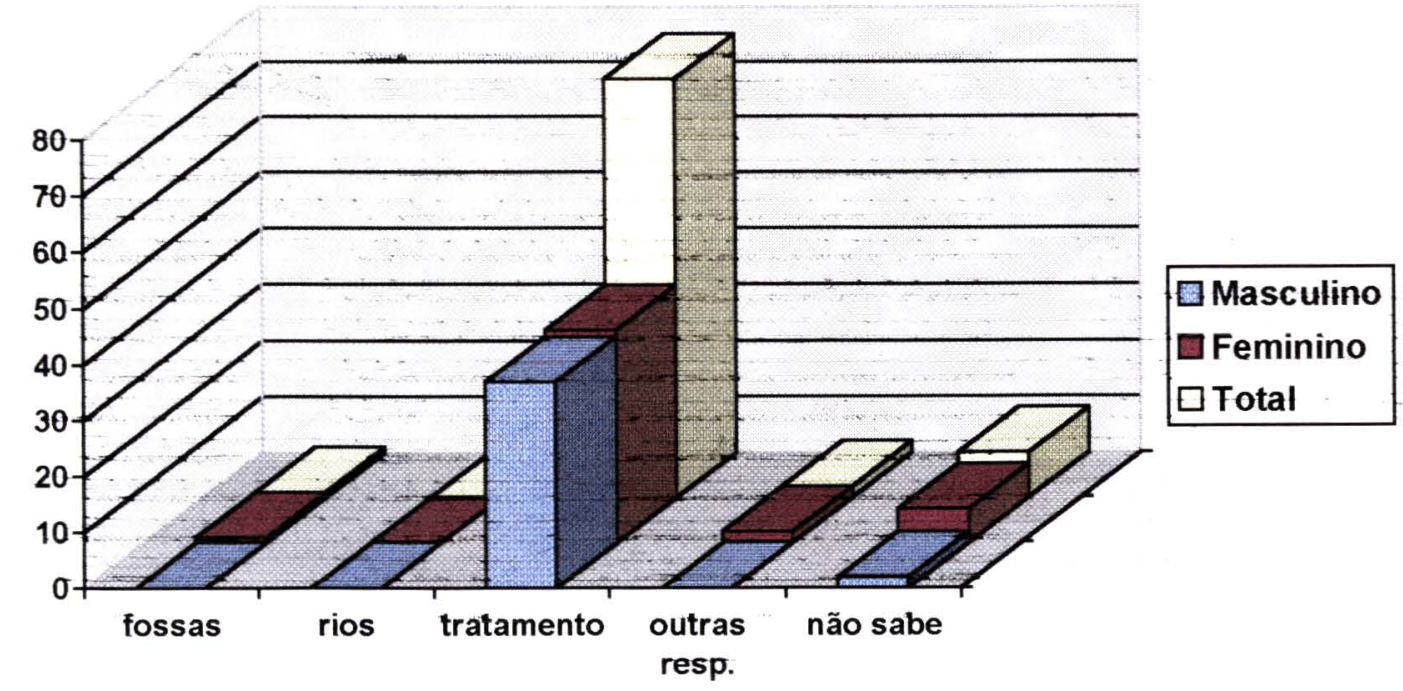

O tratamento de esgotos é defendido como a melhor solução para o problema, tanto por indivíduos do sexo masculino $(95 \%$ dos homens 
entrevistados), quanto por indivíduos do sexo feminino ( $81 \%$ das mulheres entrevistadas).

Apenas as mulheres escolheram as fossas como destino final para os esgotos $(2 \%)$ e também foi entre elas que se encontraram outras respostas, atém das alternativas apresentadas (4\%). Entre os que afirmaram não saber como responder a questão, encontram-se $5 \%$ dos homens e $13 \%$ das mulheres.

Baseando-se nestes percentuais, pode-se concluir que para a população estudada, os homens demonstraram ser mais favoráveis ao tratamento de esgotos do que as mulheres.

Quanto à percepção do impacto da proliferação de odores ofensivos do tratamento de esgotos - indicador 4, as respostas de homens e mulheres. encontram-se representadas no gráfico da FIGURA 8.3.

FIGURA 8.3 - Sexo dos entrevistados X Percepção do impacto da proliferação de odores ofensivos do tratamento de esgotos

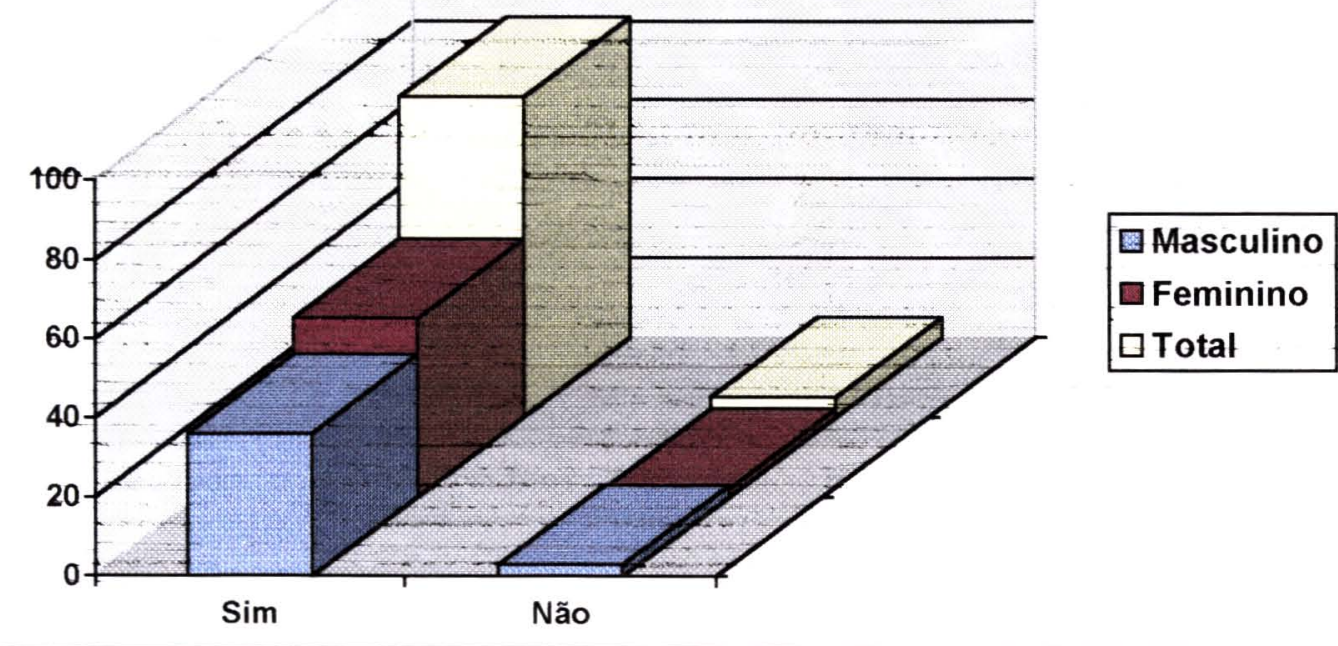


Apenas em se contemplar a FIGURA 8.3, nota-se ser bastante clara a percepção em relação aos maus odores atribuidos à operação da ETE Piracicamirim: $92 \%$ dos homens e 96\% das mulheres entrevistadas, queixaram-se do problema.

A diferença percentual entre estes índices (masculino e feminino) é praticamente inexistente, o que equivale a dizer que homens e mulheres estão plenamente de acordo, quando se trata da questão da proliferação de odores ofensivos. Este incômodo encontra-se inegavelmente presente no cotidiano desta população

A identificação da presença de odores ao longo do ano - indicador 4, tem sua representação quanto à percepção masculina e feminina, demonstrada na FIGURA 8.4.

FIGURA 8.4 - Sexo dos entrevistados X Identificação da presença de odores ao longo do ano

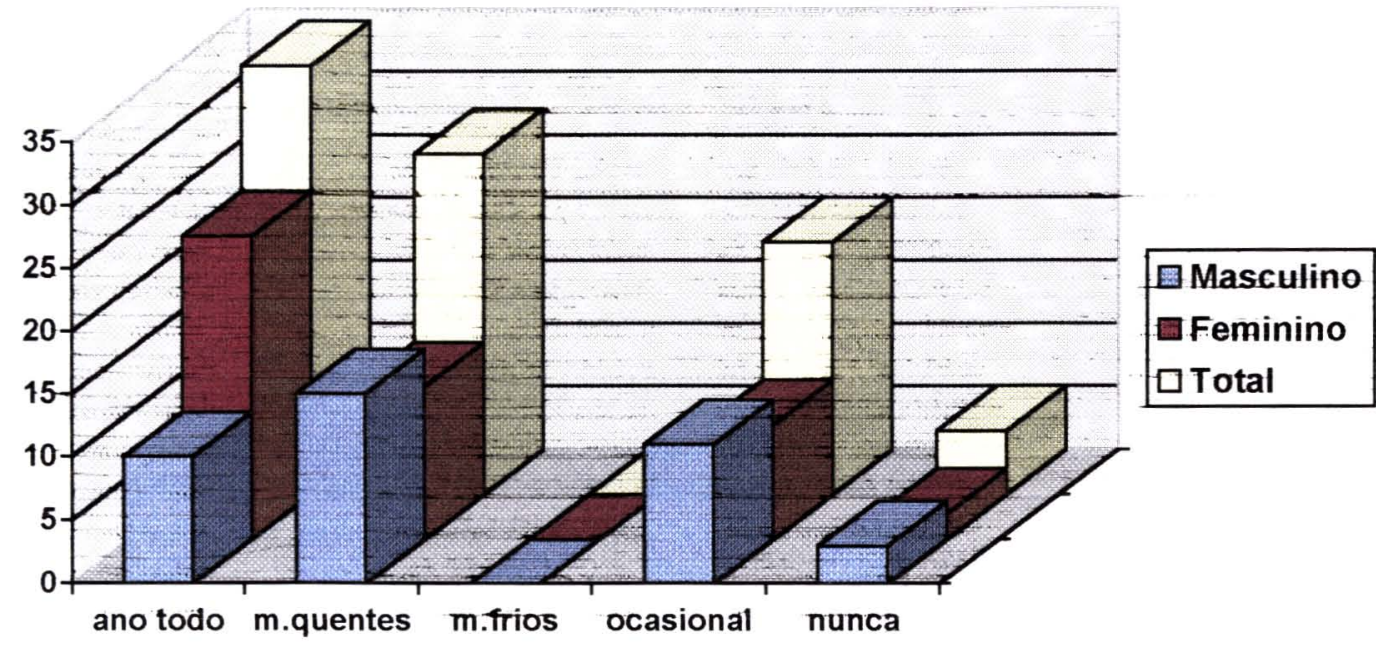


A maioria dos homens entrevistados (38\%), associa a presença de odores ofensivos aos meses quentes. Em seguida, estão aqueles que só percebem ocasionalmente o problema (28\%); após estes, estão os que afirmam que os odores estão presentes o ano todo $(26 \%)$; e por último, estão os que não se queixam de odores (8\%).

Entre as mulheres, a situação é diferente: para $51 \%$ delas, os odores. estão presentes o ano todo; $26 \%$ atribuem o problema aos meses quentes do ano; $19 \%$ afirmam que é algo ocasional; e por último, $4 \%$ nunca perceberam odores ofensivos relacionados à estação.

No que se refere ao indicador 5 - identificação da frequência dos. odores ao longo do dia, a FIGURA 8.5 apresenta a opinião de ambos os sexos.

FIGURA 8.5 - Sexo dos entrevistados X tdentificação da frequência de odores ao longo do dia

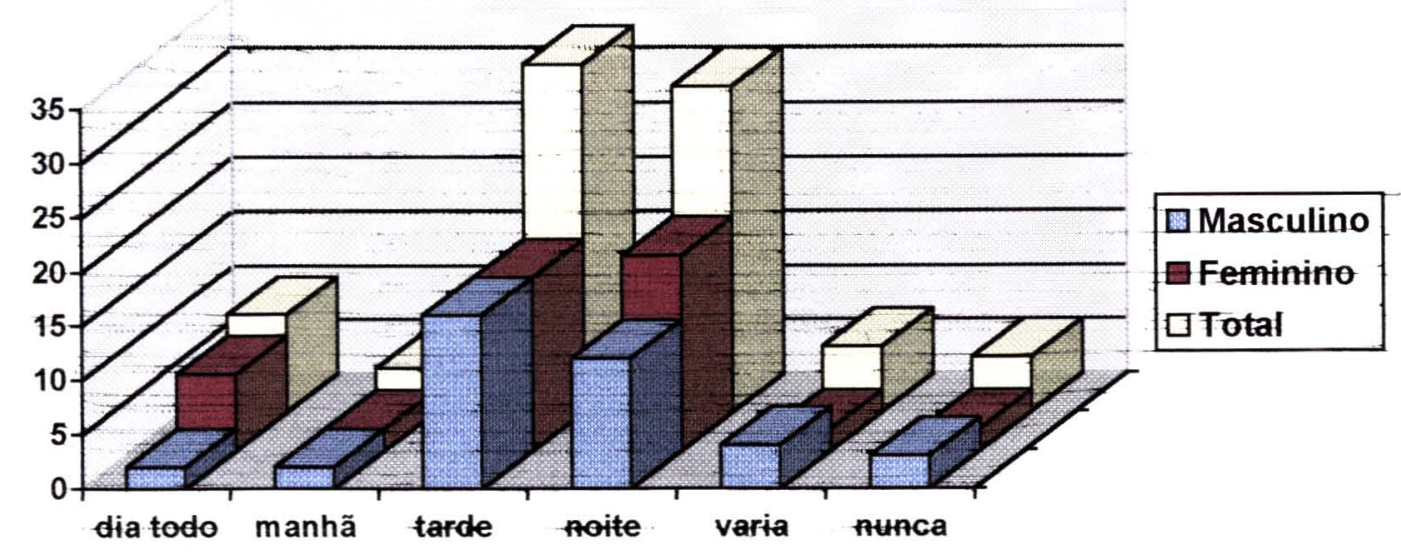


A opinião dos homens apontou o período da tarde como sendo o mais crítico $(41 \%)$; seguido pela noite $(31 \%)$; períodos diferenciados de acordo com as estações do ano (10\%); manhã (5\%); durante todo o dia (5\%); e os nunca percebem maus odores da ETE (8\%).

Já segundo as mulheres, o periodo mais complicado em relação aos odores ofensivos é o período da noite (39\%). Logo após está o período da tarde (34\%); durante todo o dia (15\%); manhã (4\%); períodos diferenciados $(4 \%)$; e as que não se queixaram de odores $(4 \%)$.

Analisando estes percentuais e ainda pela checagem "in loco" das condições locais, o que se verifica é que a questão da proliferação de odores ofensivos decorrentes da operação da ETE - Piracicamirim, afeta as populações vizinhas a partir do período da tarde, adentrando pela noite.

Em relação ao indicador 6 - percepção de fatores agravantes, tem-se a FIGURA 8.6 com a representação das respostas masculinas e femininas.

FIGURA 8.6 - Sexo dos entrevistados X Percepção de fatores agravantes

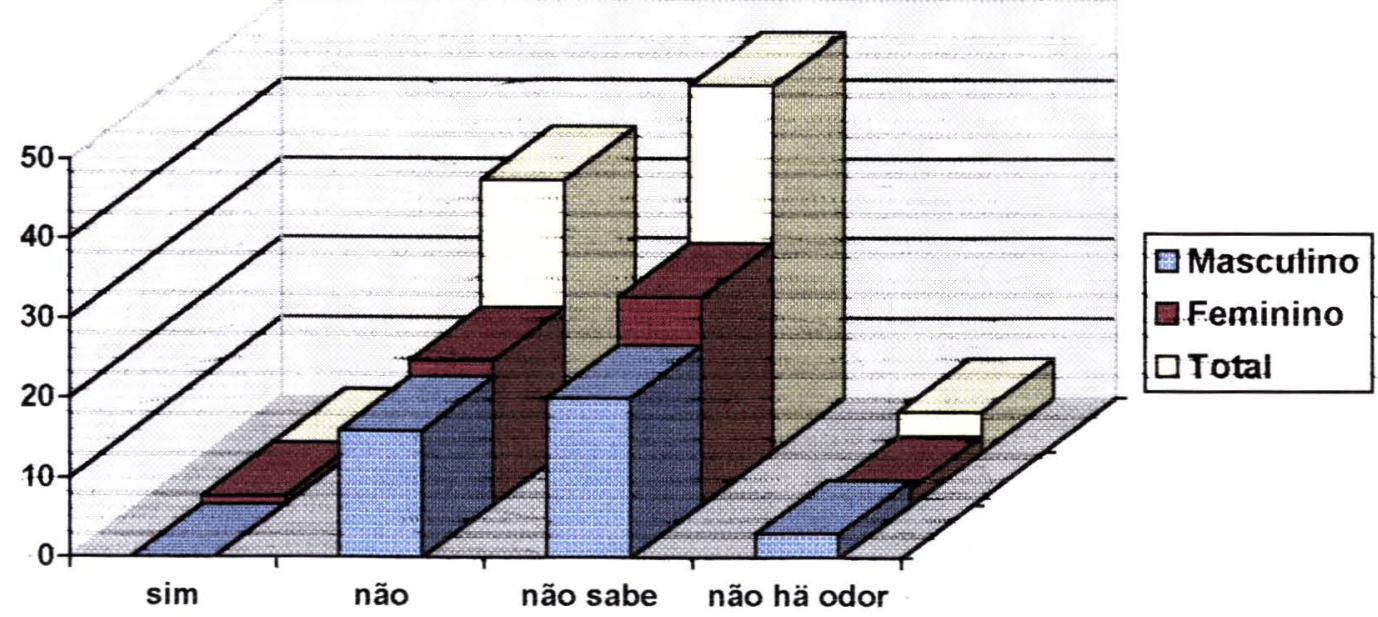


Como constatado anteriormente quando da análise preliminar do inđicađor 6, nẫo há identificação aparente de outras fontes de poluição que estejam contribuindo para agravar o problema da proliferação de odores ofensivos da ETE. Neste fato concordam homens e mulheres, conforme pode ser visto no gráfico apresentado pela FIGURA 8.6.

As respostas mascutinas dividiram-se em: $51 \%$ não sabem afirmar se existe interferência externa contribuindo para o agravamento dos maus odores; $4 \uparrow \%$ afirmaram que tat interferência não existe; $8 \%$ não se queixam de maus odores relacionados ao tratamento de esgotos.

Dentre as mulheres: $60 \%$ não sabem afirmar se existe interferência; $38 \%$ declararam que não existe nenhuma interferência externa agravando 0 problema; $4 \%$ não têm queixa de odores; e apenas $2 \%$ do público feminino alega que outras fontes de poluição próximas contribuem para agravar a questão dos maus odores.

Acerca do indicador 7 - reconhecimento de efeitos da exposição aos odores, as opiniões de homens e mulheres distribuem-se conforme demonstrado na FIGURA 8.7.

FIGURA 8.7 - Sexo dos entrevistados X Reconhecimento de efeitos da exposição aos odores

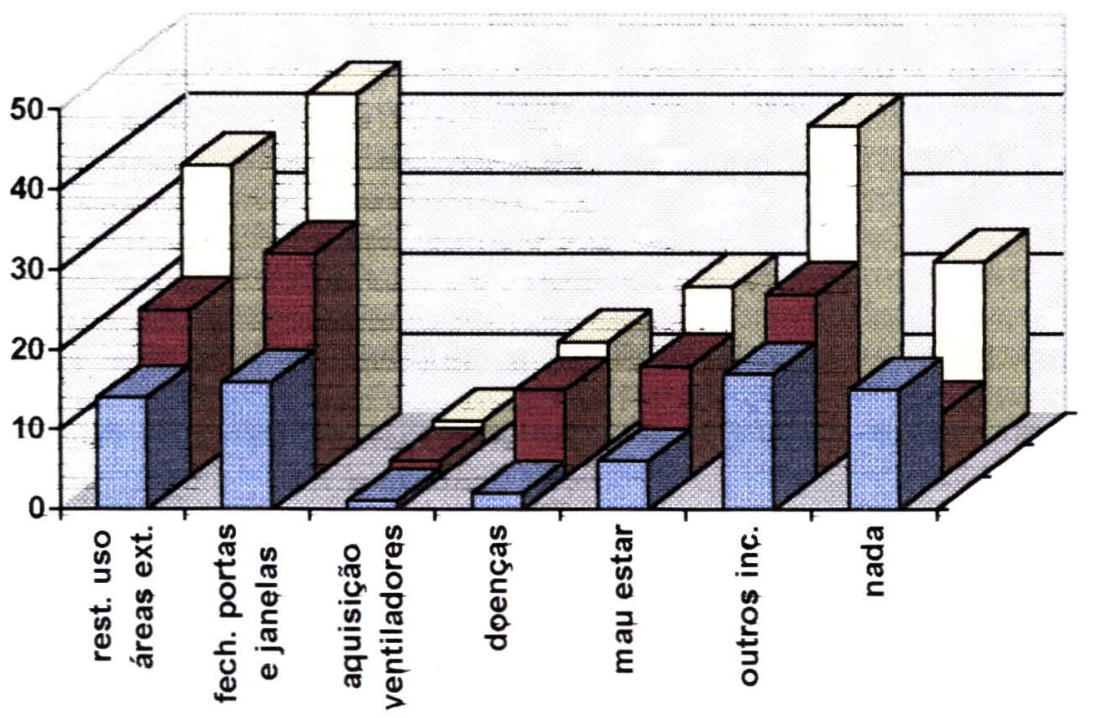


Em todos os efeitos reconhecidos, as mulheres superaram os homens em suas queixas quanto às implicações da exposição continuada aos odores ofensivos. A análise das respostas em termos percentuais, permite a verificação desta afirmação. Vale lembrar que os entrevistados podiam assinalar mais de uma alternativa, ou seja, mais de um incômodo.

Entre os homens: $41 \%$ afirmaram que já tiveram de fechar portas e janelas para se preservar dos odores; $36 \%$ tiveram restrições na utilização das áreas externas às suas residências (jardins, quintais, etc.); $38 \%$ não reconheceram efeito associado à exposição aos maus odores; $33 \%$ apresentaram outros incômodos diversos (principalmente vetores e insetos); $15 \%$ alegaram mau estar; $5 \%$ queixaram-se de doenças respiratórias e alergias; e $3 \%$ compraram ventiladores para minimizar o problema em suas casas.

Quanto às mutheres: $60 \%$ já fecharam portas e janelas para tentar "fugir" dos odores ofensivos; $49 \%$ queixaram-se de incômodos diversos aos apresentados pelo questionário (também prevalecendo insetos e vetores); $45 \%$ tiveram seu uso de quintais e jardins comprometido pelo problema; $30 \%$ queixaram-se de mau estar, $23 \%$ de doenças respiratórias e alergias; $17 \%$ não associaram nenhum efeito ao problema; e $4 \%$ alegaram a necessidade da compra de ventiladores.

\section{Variável 2-Faixa Etária dos Entrevistados}

No questionário, os entrevistados foram identificados em faixas etárias de 10 a $15 ; 16$ a 25; 26 a 35; 36 a 45; 46 a 55; 56 a 65; e acima de 65 anos.

De maneira a facilitar a análise desta variável em relação aos indicadores estudados, decidiu-se por agrupar estas faixas etárias da seguinte forma: 
Jovens - indivíduos de 10 a 25 anos;

Adultos - indivíduos de 26 a 55 anos;

- Idosos - indivíduos de 56 anos e acima.

Os 86 entrevistados ficaram assim divididos no que se refere ao seus grupos etários:

$$
\begin{aligned}
& \checkmark \text { Jovens }=20 \text { indivíduos }(23 \%) ; \\
& \checkmark \text { Adultos }=46 \text { indivíduos }(54 \%) \text {; } \\
& \checkmark \text { Idosos }=20 \text { indivíduos }(23 \%)
\end{aligned}
$$

$\mathrm{Na}$ população estudada, tem-se que o percentual de jovens e idosos entrevistados foi o mesmo (23\%), enquanto que o de adultos foi superior (54\%), constituindo-se no grupo mais fortemente representado.

Os indivíduos pertencentes ao grupo de adultos, apresentaram características que correspondem ao conceito de População em ldade Ativa - PIA ou seja, população em idade de trabalho e detentora de força produtiva, elaborado pela Fundação SEADE (Sistema Estadual de Análise de Dados) e apresentado em SEADE, 1992.

O comportamento dos diferentes grupos etários em face aos indicadores da percepção popular, será apresentado a seguir - FIGURAS 8.8 a 8.14 .

A FIGURA 8.8 apresenta as respostas de jovens, adultos e idosos quanto ao indicador 1 - conhecimento do órgão de saneamento local. 


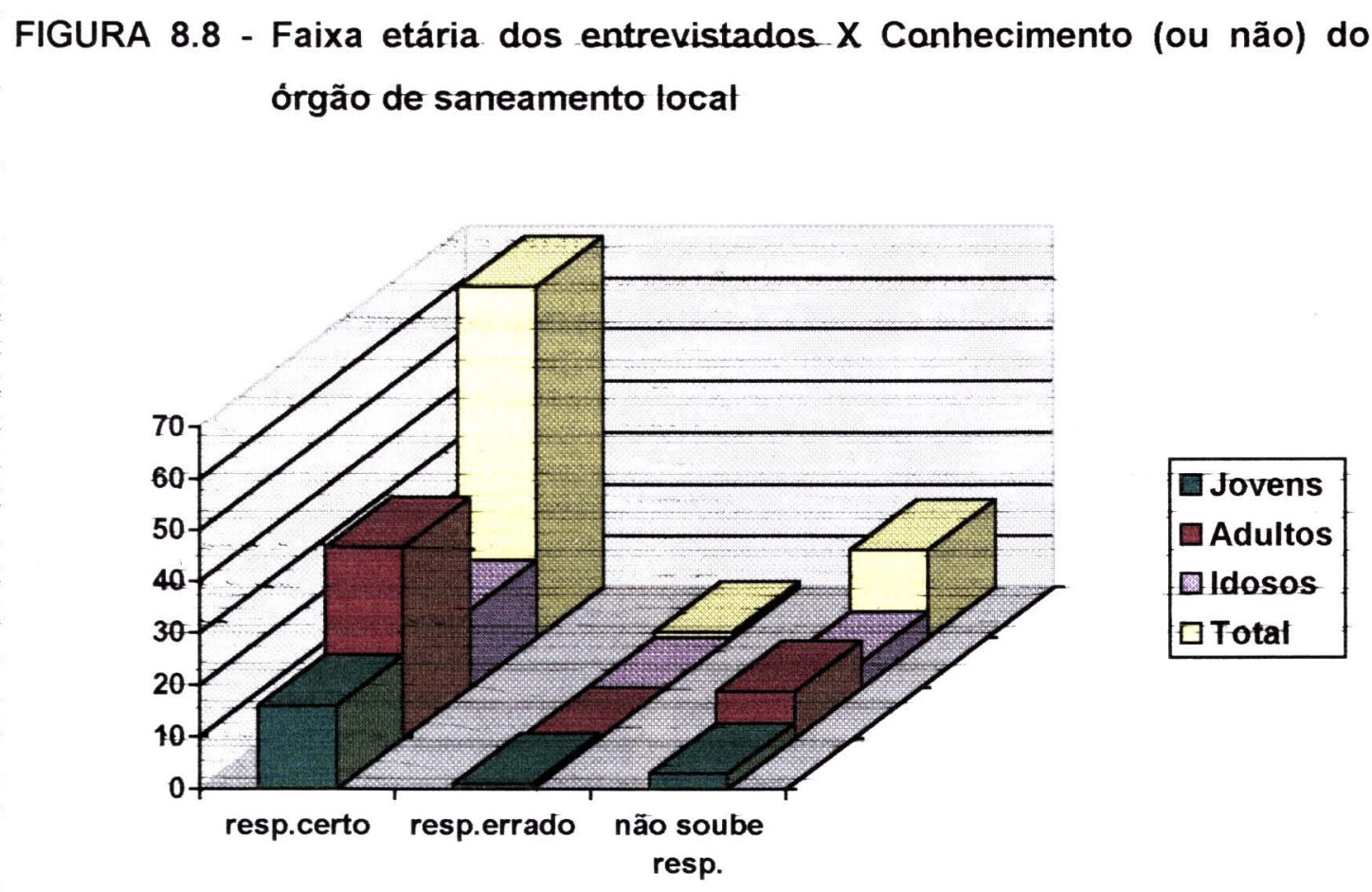

Analisando as respostas obtidas dos diferentes grupos etários, temos que os jovens apresentaram um índice de $80 \%$ acerto; $15 \%$ de đesconhecimento; e 5\% đe erro em relaçăo ao órgão đe saneamento local.

Entre os adultos as porcentagens foram de $80 \%$ de acerto e $20 \%$ de desconhecimento. Nenhum adulto arriscou uma resposta que nâo fosse a correta para a questão.

Os idosos apresentaram $75 \%$ de acerto e $25 \%$ de desconhecimento. Também entre eles, ninguém se aventurou a "advinhar" o nome do responsávet petos serviços de água e esgotos do município.

De modo geral, os grupos etários comportaram-se de maneira bem semelhante em relação ao indicador 1 . Destaca-se apenas o erro de $5 \%$ dos jovens ao apontar o nome do órgão de saneamento, que pode muito bem ser explicado pela pressa em se responder e pela necessidade de se responder alguma coisa, bastante característicos da idade. 
A FIGURA 8.9 traz o comportamento dos grupos etários frente a questão do destino final dos esgotos sanitários.

FIGURA 8.9 - Faixa etária dos entrevistados X Opinião sobre a disposição dos esgotos

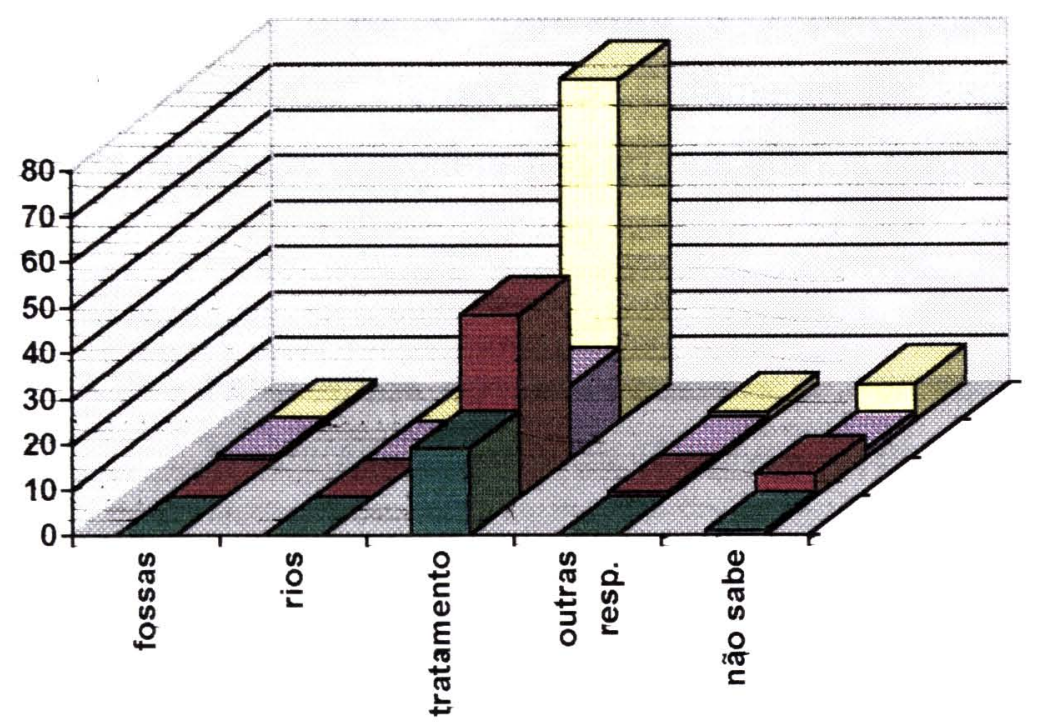

A opinião dos jovens em relação à disposição dos esgotos é bastante clara e facilmente demonstrada pelos percentuais de suas respostas: $95 \%$ deles declararam-se a favor do tratamento de esgotos, considerando ser a melhor solução; e $5 \%$ ategaram não saber quat seria a solução adequada para o problema.

Os adultos apresentaram os seguintes percentuais: 87 consideraram o tratamento como melhor alternativa; $11 \%$ afirmaram não saber como responder à questão; e $2 \%$ deram outras respostas.

Entre os idosos, os percentuais foram: $80 \%$ responderam que 0 esgoto deve ser tratado; $10 \%$ não souberam responder à questão; $5 \%$ responderam que as fossas são a melhor alternativa; e os restantes 5\% deram outras respostas diferentes. 
Através da análise dos percentuais dos diferentes grupos etários, conclui-se que os jovens são os mais propensos à defesa da prática do tratamento de esgotos sanitários; em segundo lugar encontram-se os adultos; e por último, os iđosos. Levando-se em conta que a questão ambiental tem feito parte do cotidiano escolar e de trabalho das novas gerações, temos aí a explicação deste fato.

Na FIGURA 8.10, o indicador 3 - percepção do impacto da proliferação de odores ofensivos do tratamento de esgotos, é analisado através das respostas dos diferentes grupos etários considerados.

FIGURA 8.10 - Faixa etária dos entrevistados X Percepção do impacto da proliferação de odores ofensivos do tratamento de esgotos

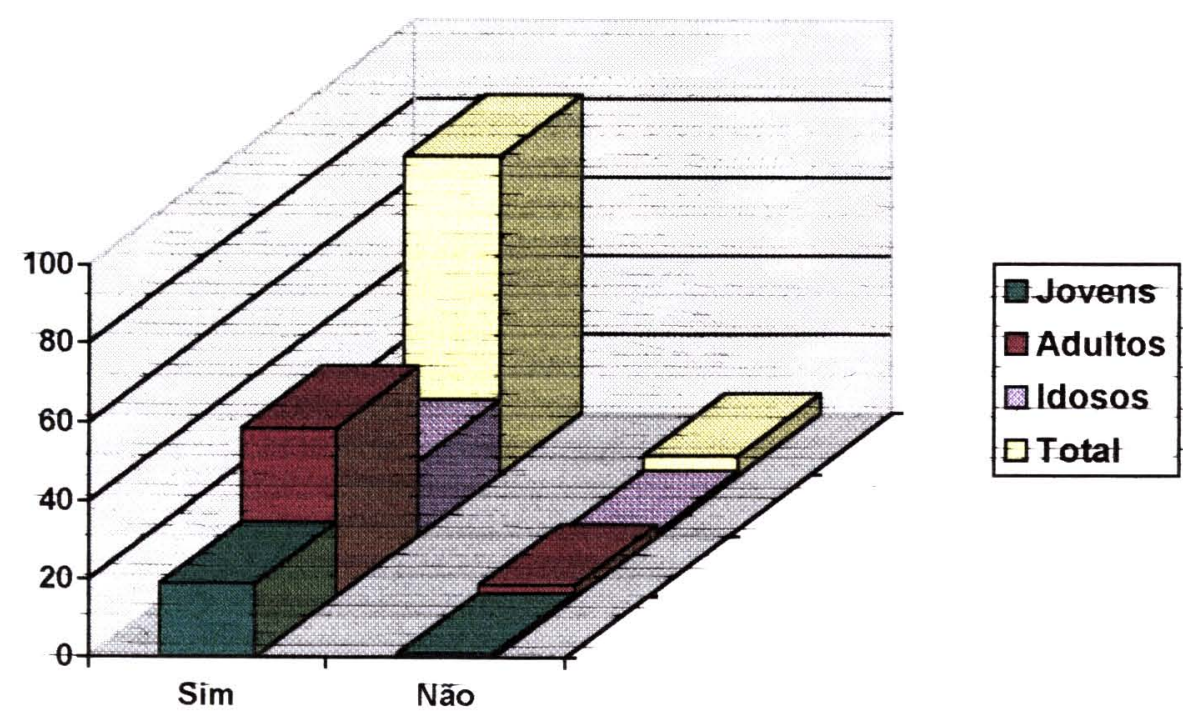

Quanto à percepção do impacto estudado, têm-se dentre aqueles que o identificaram: $95 \%$ dos jovens; $95 \%$ dos idosos, e $93 \%$ dos adultos. 
Estes percentuais são suficientes para embasar a afirmação de que para qualquer das faixas etárias consideradas, a proliferação de odores ofensivos trata-se de um fato real e cotidiano.

O indicador 4 - identificação da presença dos odores ao longo do ano, é analisado frente às respostas de jovens, adultos e idosos na FIGURA 8.11 .

\section{FIGURA 8.11 - Faixa etária dos entrevistados X Identificação da presença de} odores ao longo do ano

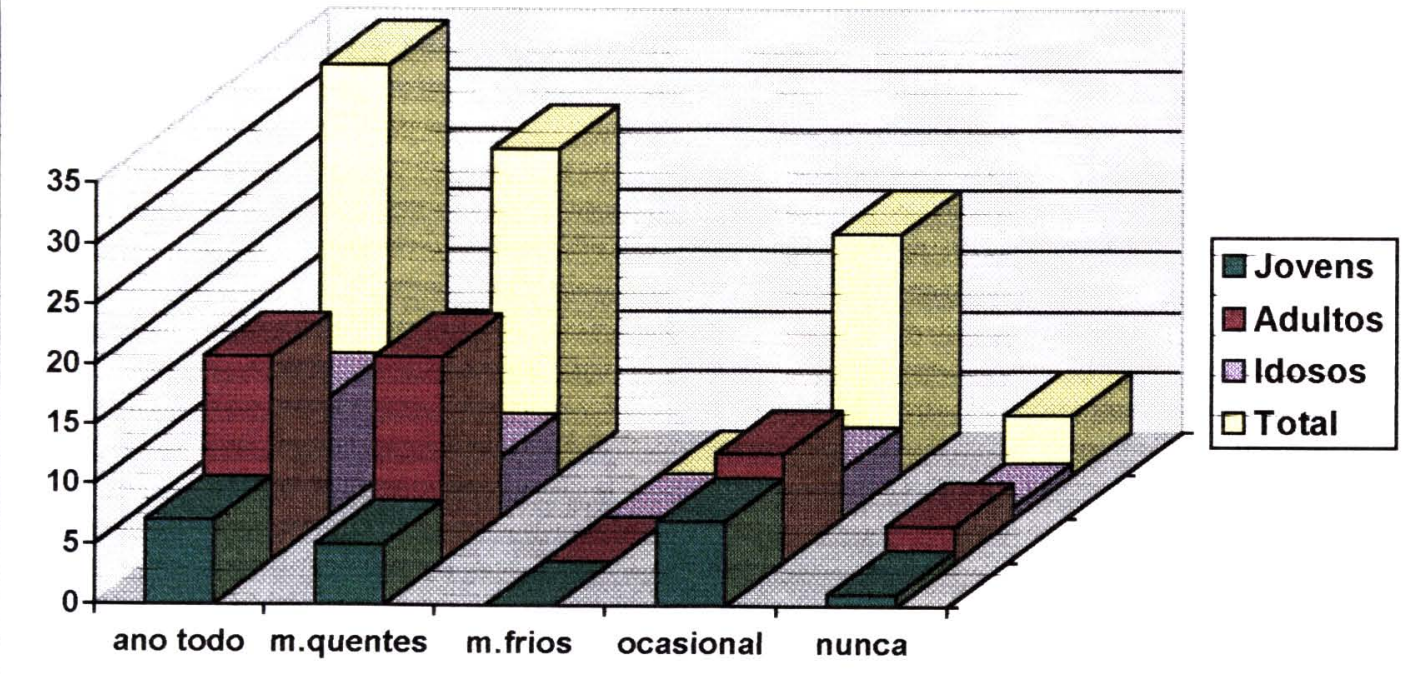

Os jovens identificaram a presença de odores ao longo do ano da seguinte forma: $35 \%$ durante o ano todo; $35 \%$ ocasionalmente; $25 \%$ nos meses quentes; e $5 \%$ não se queixaram de odor algum.

Já os adultos responderam assim: $37 \%$ durante o ano todo; $37 \%$ nos meses quentes; $19 \%$ ocasionalmente; e $7 \%$ não identificaram odor relacionado à estação. 
Entre os idosos as respostas se dividiram em: $50 \%$ durante o ano todo; $25 \%$ durante os meses quentes; $20 \%$ ocasionalmente; e $5 \%$ nunca perceberam odores ofensivos.

Mais uma vez, os três grupos etários distribuíram suas respostas de maneira bastante semelhante, não havendo divergências significativas.

O comportamento das faixa etárias em relação ao indicador 5 identificação da frequência dos odores ao longo do dia, é o objeto da FIGURA 8.12

FIGURA 8.12 - Faixa etária dos entrevistados X Identificação da frequência de odores ao longo do dia

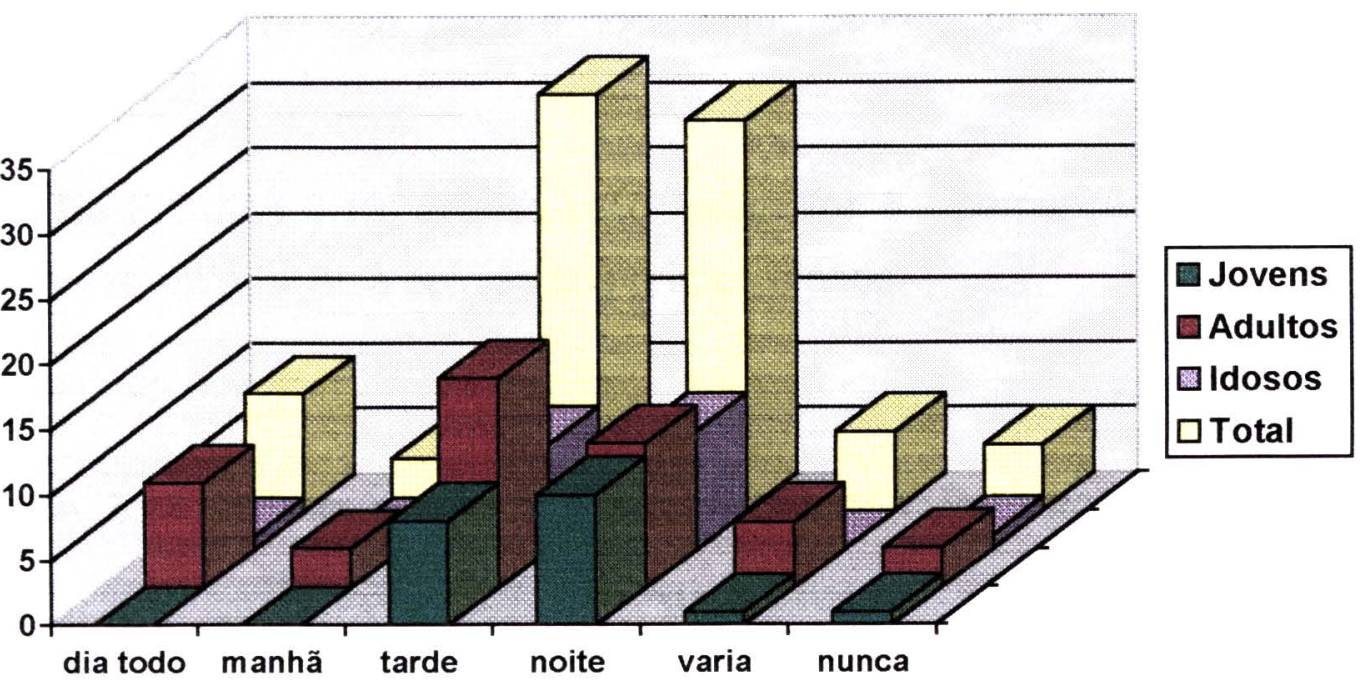

As respostas dos jovens em relação à frequência de odores ao longo do dia apontaram o período da noite como sendo o mais crítico (50\%); seguido pelo período da tarde (40\%); períodos diferenciados $(5 \%)$; e o percentual restante $(5 \%)$, corresponde aos entrevistados que não identificaram odores em período algum do dia. 
Os adultos apresentaram as seguintes respostas: $35 \%$ apontaram o período da tarde como o mais crítico; seguido pelo período da noite com $24 \%$ das respostas; logo após com $17 \%$, estão os que afirmaram que os odores estão presentes o dia todo; $11 \%$ responderam que os odores apresentam-se em períodos variados; $6 \%$ disseram que o período da manhã é o mais complicado; e os demais $7 \%$ que não se queixaram de odor.

Quanto aos idosos as respostas dividiram-se em: $45 \%$ indicaram a noite como período crítico; $40 \%$ escolheram o período da tarde; $5 \%$ o período da manhã; $5 \%$ o dia todo; e 5\% não perceberam odores advindos da ETE - Piracicamirim, em período algum do dia.

Para este indicador, as respostas dos grupos etários foram bem diferenciadas, apesar de que os períodos da noite e da tarde foram os mais apontados por jovens e idosos, nesta ordem; já para os adultos, a ordem aparece inversa, ou seja, tarde e noite, como os mais críticos períodos do dia.

$\mathrm{Na}$ FIGURA 8.13, analisa-se o indicador 6 - percepção de fatores agravantes em relação à opinião dos grupos etários.

FIGURA 8.13 - Faixa etária dos entrevistados X Percepção de fatores agravantes

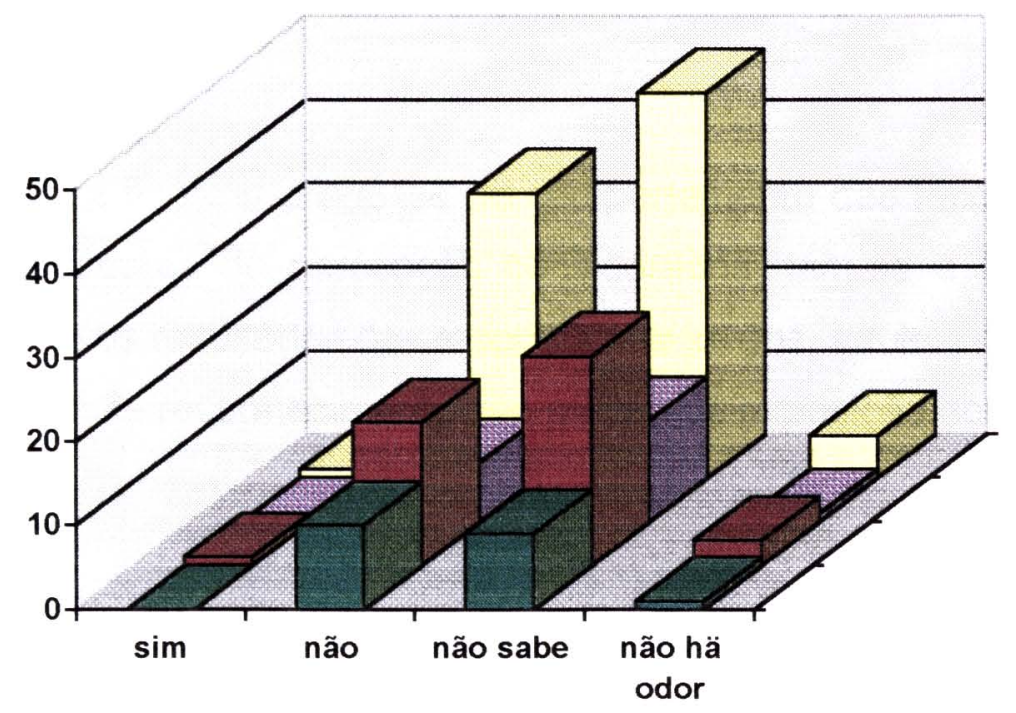

\begin{tabular}{|l|}
$\square$ Jovens \\
$\square$ Adultos \\
$\square$ Idosos \\
$\square$ Total
\end{tabular} 
$\mathrm{Na}$ percepção de fatores agravantes, as respostas dos jovens dividiram-se em: $50 \%$ afirmaram que não há interferência externa contribuindo para o agravamento dos odores ofensivos; $45 \%$ não souberam responder à pergunta; e os $5 \%$ restantes não identificaram o problema dos odores em tempo algum.

Entre os adultos, as respostas foram: $54 \%$ declararam não saber responder à pergunta: $37 \%$ afirmaram que não há outras fontes de poluição agravando os maus odores; $7 \%$ continuaram afirmando desconhecer 0 problema da proliferação de odores; e $2 \%$ afirmaram haver sim, interferências externas contribuindo para complicar ainda mais a situação.

Já entre os idosos, têm-se: $60 \%$ que não se julgaram aptos para responder à pergunta; $35 \%$ que declararam não haver interferência agravando o problema; e $5 \%$ que continuaram não se queixando de odores relativos ao tratamento de esgotos.

Pelas respostas, percebe-se a cautela de adultos e idosos em responder à questão formulada, preferindo passar adiante do que arriscar uma colocação sem embasamento; enquanto os jovens. estes não hesitaram em afirmar a não existência de fatores agravantes relacionados ao problema dos maus odores.

Para finalizar a análise do comportamento das faixas etárias em face aos indicadores de percepção considerados, tem-se a FIGURA 8.14 que apresenta os resultados das respostas de jovens, adultos e idosos acerca do indicador 7 - reconhecimento dos efeitos da exposição aos odores 


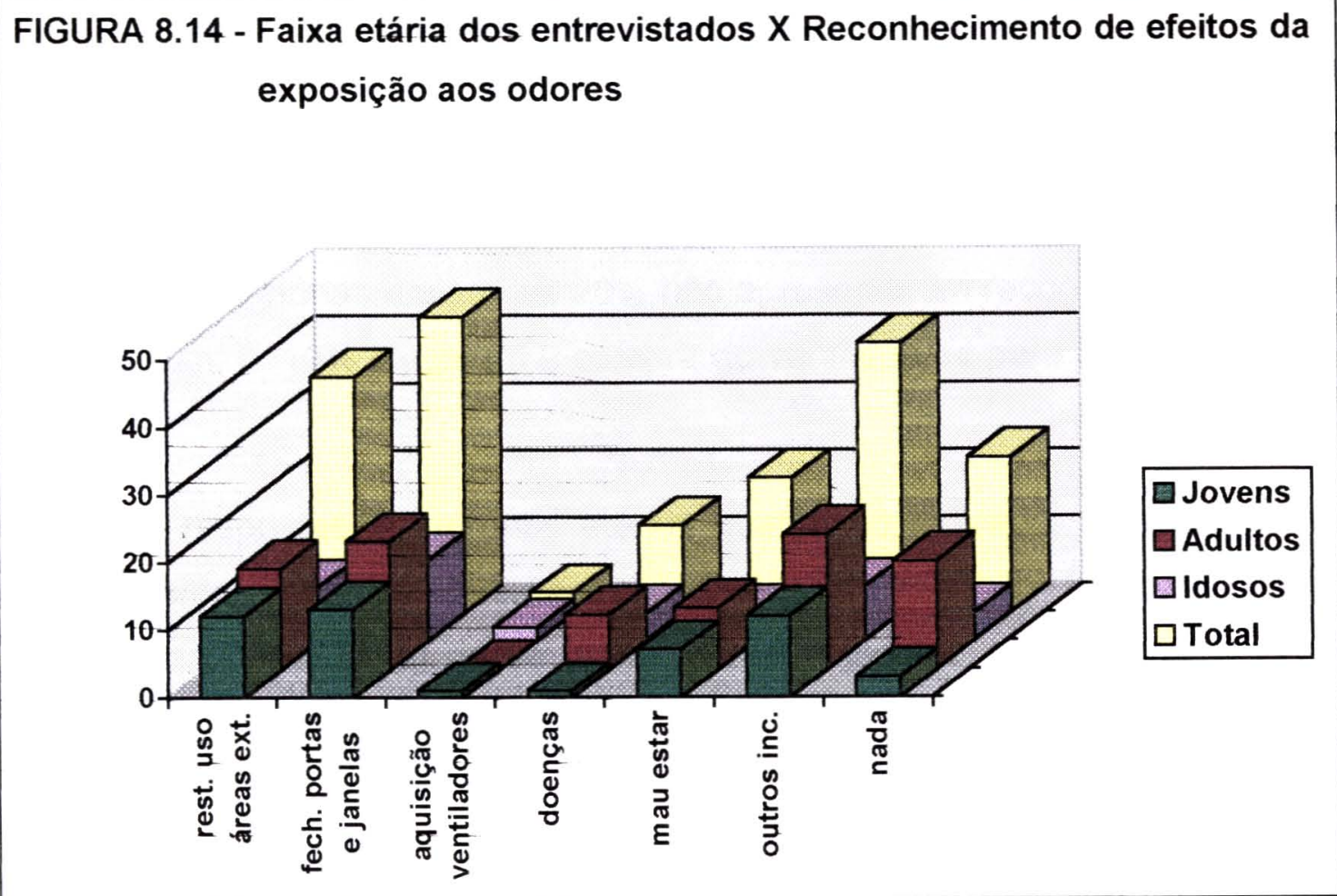

O reconhecimento dos efeitos da exposição aos odores por parte dos jovens, deu-se da seguinte forma: $65 \%$ alegaram que já tiveram que fechar portas e janelas devido ao problema; $60 \%$ apresentaram restrições no uso das áreas externas à residência; $60 \%$ indicaram outros incômodos diversos dos relacionados pelo questionário; 35\% já tiveram mau estar em decorrência dos odores; $45 \%$ não reconheceram efeito algum associado aos odores; $5 \%$ apresentaram doenças respiratórias e alergias; e, outros 5\% afirmaram que tiveram que comprar ventiladores para enfrentar a situação de maneira mais confortável.

Para os adultos, os efeitos dividiram-se assim: $43 \%$ apresentaram incômodos diversos aos contemplados pelo questionário; $41 \%$ já fecharam portas e janelas para tentar "fugir" do problema; $35 \%$ não associaram nenhum efeito ruim aos odores; 33\% tiveram o uso de áreas externas da residência restrito; $20 \%$ queixaram-se de mau estar; e, 17\% de doenças respiratórias e alergias. 
Entre os idosos, foram estas as respostas: $60 \%$ já precisaram fechar portas e janelas devido aos odores; $40 \%$ apresentaram alguma forma de restrição ao uso de áreas externas à residência (jardins e quintais); 40\% indicaram incômodos diversos; $20 \%$ queixaram-se de mau estar; $20 \%$ de doenças respiratórias e alergias; $20 \%$ não apresentaram reconhecimento de efeito algum; e, $10 \%$ alegaram a compra de ventiladores para o combate ao problema.

As respostas dos grupos etários quanto ao indicador 7 , apesar de apresentarem algumas divergências, destacam o hábito (adquirido em decorrência do impacto) de se fechar portas e janetas, na tentativa de se "isolar" do problema.

\section{Variável 3 - Renda Familiar}

Em relação à variável 3 - Renda familiar, os entrevistados posicionaram-se da seguinte forma:

\begin{tabular}{|c|c|c|c|}
\hline Até 3 salários mínimos & $=$ & 6 & $(7 \%)$ \\
\hline Até 5 salários mínimos & $=$ & 12 & $(14 \%)$ \\
\hline Até 10 salários mínimos & $=$ & 31 & $(36 \%)$ \\
\hline Acima de 10 salários mínimos & $=$ & 25 & $(29 \%)$ \\
\hline - Preferem não declarar & $=$ & 12 & $(14 \%)$ \\
\hline
\end{tabular}


Sendo que este último grupo, composto pelos indivíduos que "preferem não declarar" sua renda, apresentou caracteristicas que permitem sua classificação na categoria "acima de 10 s.m.", quando da listagem dos bens de consumo existentes no imóvel (questão 19 do questionário).

Também em relação aos grupos que declaram renda "até 3 s.m." e "até $5 \mathrm{s.m.",} \mathrm{cujas} \mathrm{porcentagens} \mathrm{em} \mathrm{separado} \mathrm{foram} \mathrm{pequenas} \mathrm{e} \mathrm{com} \mathrm{o}$ objetivo de facilitar a análise dos resultados obtidos em campo, resolveu-se por agrupá-los em uma única categoria.

A nova classificação, válida para os fins de análise frente aos indicadores da percepção popular, ficou assim composta:

$\begin{array}{llll}\checkmark \text { Grupo I: até } 5 \text { s.m. } & =18 \quad(21 \%) \\ \checkmark \text { Grupo II: até } 10 \text { s.m. } & =31 \quad(36 \%) \\ \checkmark \text { Grupo III: acima de } 10 \text { s.m. } & =37 \quad(43 \%)\end{array}$

Antes de se proceder à verificação do comportamento dos diferentes grupos de renda familiar em relação aos indicadores considerados, vale destacar que de uma maneira geral, a população estudada apresentou poder aquisitivo caracteristico de classe média (SEADE, 1992), pela análise conjunta da renda dectarada, bens de consumo e informações do imóvel residencial (VALÊNCIO, 1997).

Após estas considerações, pode-se então passar ao estudo da FIGURA 8.15, que apresenta o comportamento da variável 3 frente ao indicador 1 - conhecimento (ou não) do órgão de saneamento tocal. 


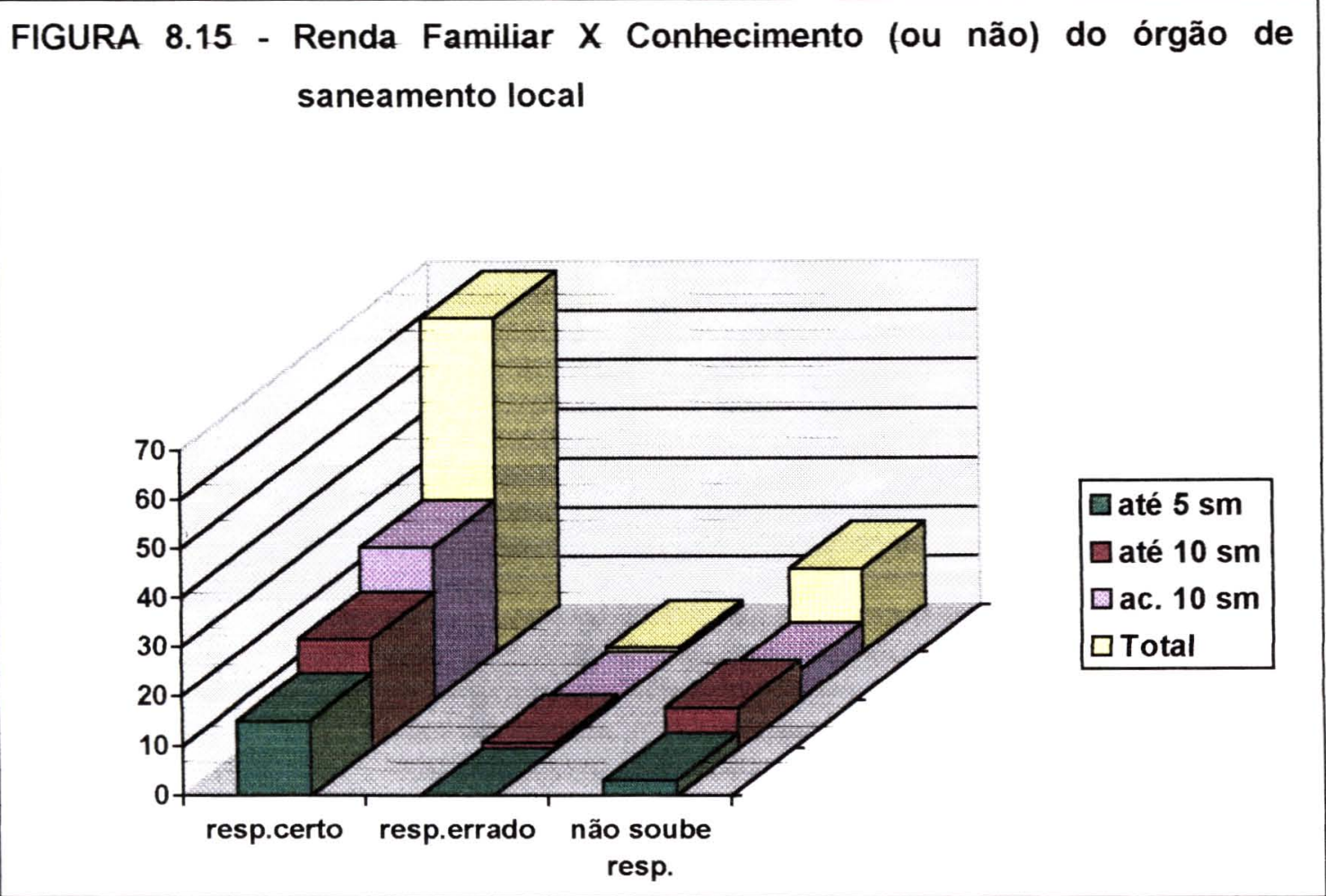

Dos representantes do Grupo I (até 5 s.m.), 83\% apontaram o SEMAE como o responsável pelos serviços de água e esgoto da cidade; e, os outros $17 \%$ não souberam responder à questão formulada.

Entre os entrevistados do Grupo II (até 10 s.m.), a porcentagem dos que acertaram à pergunta foi de $71 \%$; sendo que $26 \%$ não souberam responder; e, $3 \%$ responderam errado.

No Grupo III (acima de 10 s.m.), as respostas dividiram-se em: 84\% de acerto; e, $16 \%$ de entrevistados que não souberam como responder à pergunta.

Na análise dos percentuais, verifica-se que o Grupo II (até 10 s.m.) foi o que mais apresentou variações nas respostas, enquanto que o comportamento dos dois outros grupos foi bastante semelhante.

A FIGURA 8.16 apresenta a variável renda familiar em face do indicador 2 - opinião sobre a disposição dos esgotos. 
FIGURA 8.16 - Renda Familiar X Opinião sobre a disposição dos esgotos

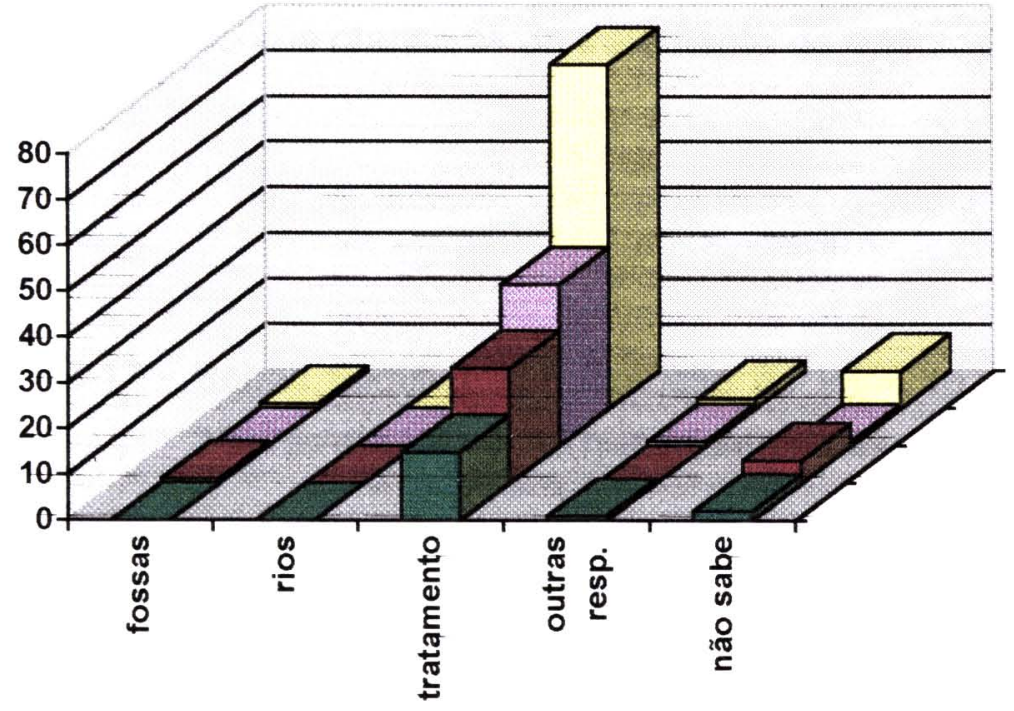

As opiniões do Grupo I (até 5 s.m.) dividiram-se assim: 83\% a favor do tratamento; $11 \%$ alegaram não saber responder à pergunta; e, 5\% apresentaram outras respostas diversas.

Já o Grupo II (até 10 s.m.) respondeu da seguinte forma: $81 \%$ a favor do tratamento como melhor alternativa para os esgotos; $16 \%$ não souberam responder; e, 3\% afirmaram que as fossas são a melhor solução.

Entre o Grupo IIt, as opiniões foram: 94\% defendem a prática do tratamento como solução mais adequada para a disposição dos esgotos; $3 \%$ não souberam responder; e, os restante $3 \%$ apresentaram outras respostas diferentes das alternativas propostas pelo questionário.

Nota-se que em relação ao tratamento de esgotos, os maiores defensores estão entre os indivíduos de maior poder aquisitivo, pelo menos para esta população anatisada. 
A FIGURA 8.17 apresenta as respostas dos diferentes grupos de renda considerados, acerca do indicador 3 - percepção do impacto da proliferação de odores ofensivos do tratamento de esgotos.

FIGURA 8.17 - Renda Familiar X Percepção do impacto da proliferação de odores ofensivos do tratamento de esgotos

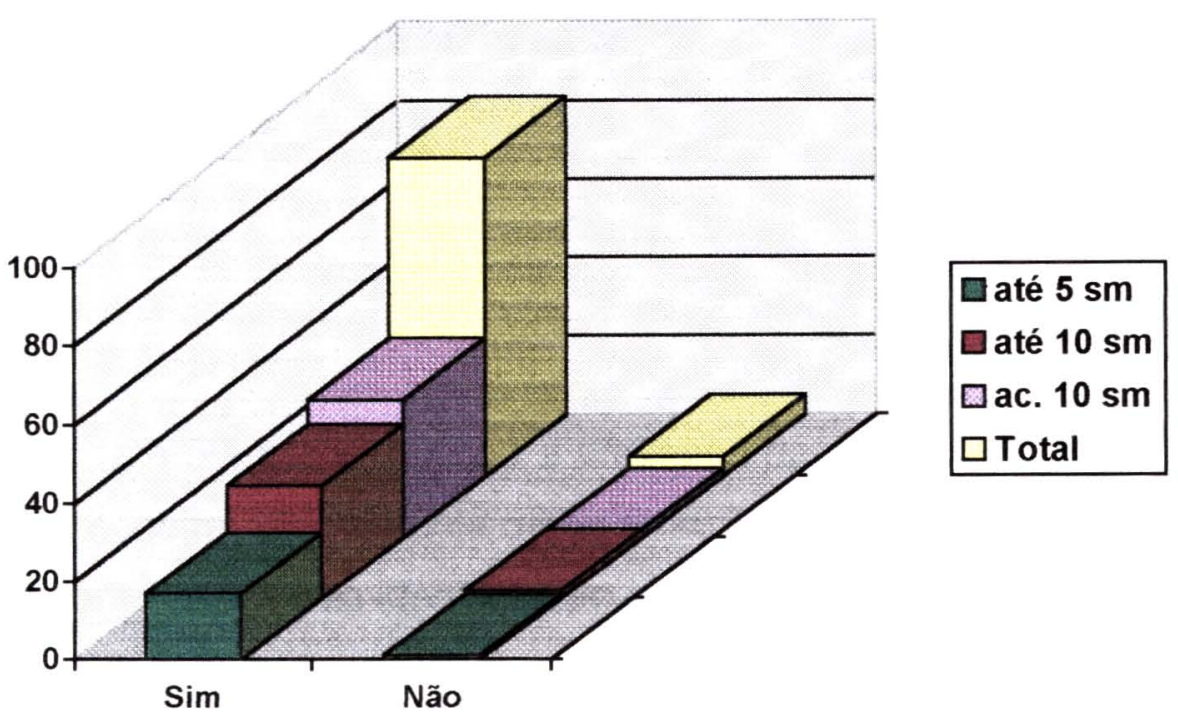

As porcentagens de percepção do impacto analisado foram as seguintes: $94 \%$ dos indivíduos do Grupo I (até 5 s.m.); $94 \%$ dos entrevistados do Grupo II (até 10 s.m.); e, 95\% dos representantes do Grupo III (acima de 10 s.m.).

Quanto à variável renda, não houveram muitas variações de percepção por parte dos entrevistados, no que tange à proliferação de odores ofensivos da ETE - Piracicamirim.

Na FIGURA 8.18, contempla-se a variável 3 frente à identificação da presença de odores ao longo do ano - indicador 4. 


\section{FIGURA 8.18 - Renda Familiar X Identificação da presença de odores ao longo} do ano

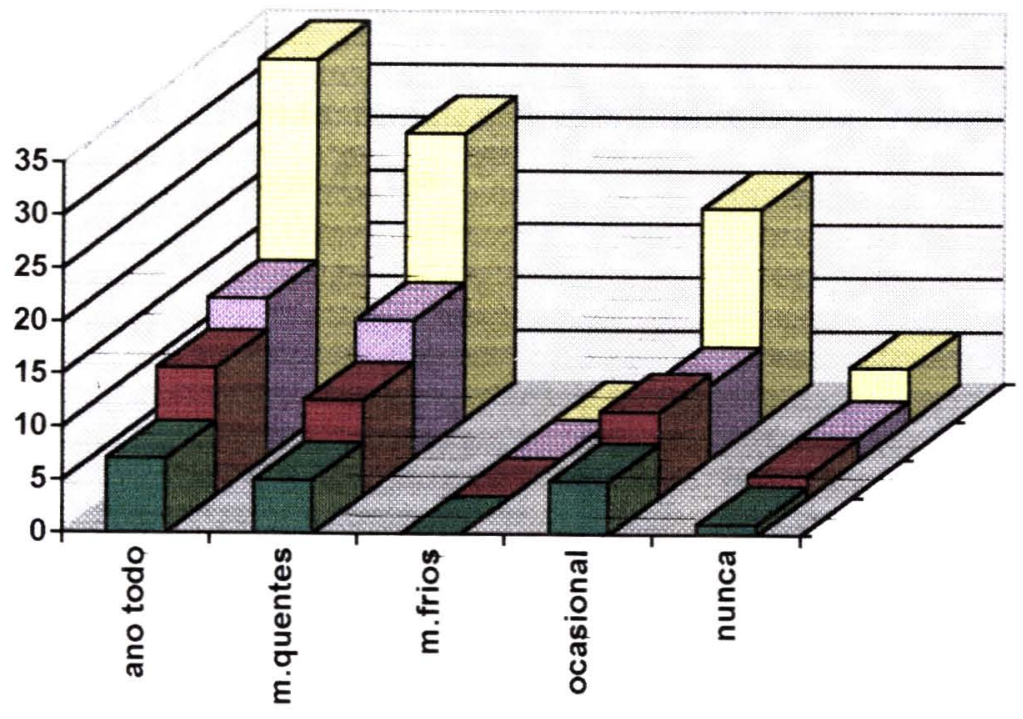

O Grupo I (até 5 s.m.) identificou a presença de odores ao longo do ano da seguinte maneira: $38 \%$ durante o ano todo; $28 \%$ nos meses quentes; $28 \%$ ocasionalmente; e, $6 \%$ não identificaram em tempo algum.

O Grupo II (até 10 s.m.) relacionou suas respostas da seguinte forma: $39 \%$ durante 0 ano todo; $29 \%$ durante os meses quentes; $26 \%$ ocasionalmente; e, $6 \%$ não se queixaram de odor em nenhuma época do ano.

Já o Grupo III (acima de 10 s.m.) apresentou os seguintes resultados: $41 \%$ durante o ano todo; $35 \%$ nos meses quentes; $19 \%$ ocasionalmente; e, $5 \%$ não identificaram odor algum associado à ETE.

As respostas dos grupos seguiram uma mesma sequência de identificação: ano todo; meses quentes; ocasionalmente e nunca. $O$ comportamento dos grupos frente ao indicador 4, não sofreu variações significativas. 
A variável renda familiar é analisada em relação ao indicador 5 identificação da frequência dos odores ao longo do dia, na FIGURA 8.19.

\section{FIGURA 8.19 - Renda familiar X Identificação da frequência de odores ao longo do dia}

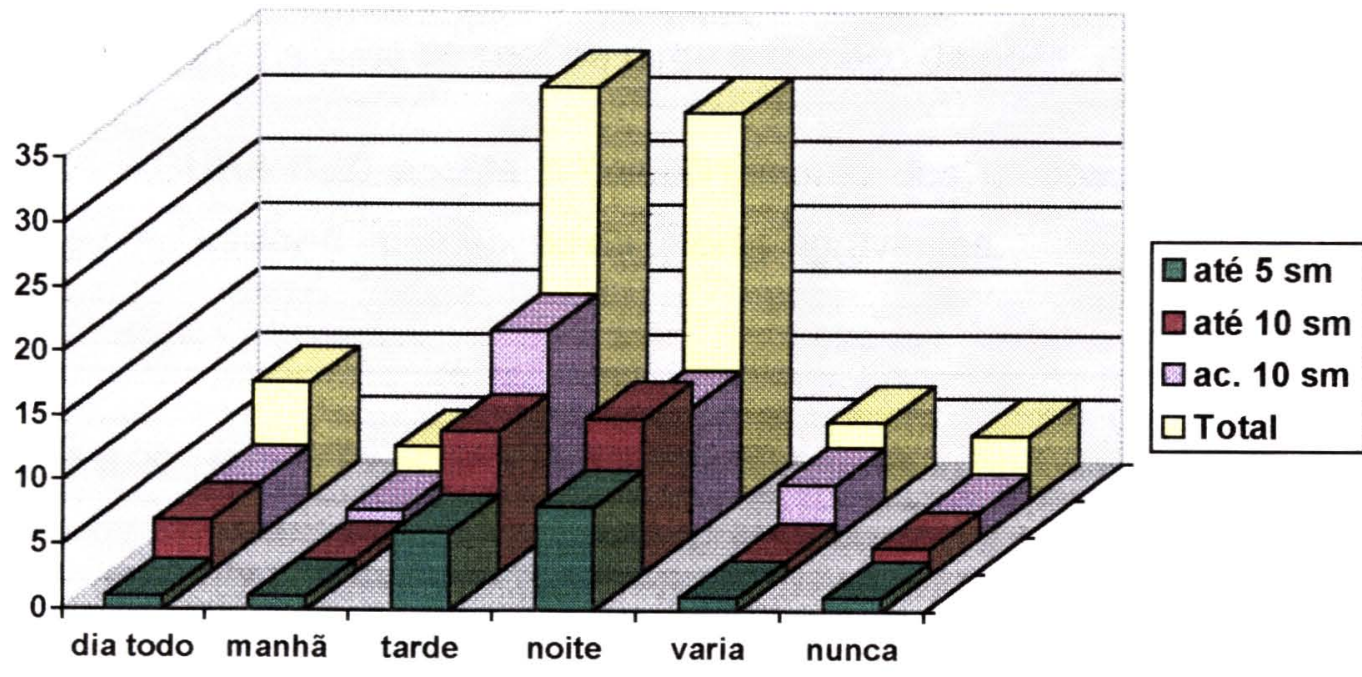

Para o Grupo I (até 5 s.m.), a identificação da frequência de odores ao longo do dia foi a seguinte: $44 \%$ afirmaram que a noite é o período mais crítico; $32 \%$ disseram ser o período da tarde; $6 \%$ afirmaram que os odores estão presentes o dia todo; $6 \%$ acham que o período da manhã é o mais complicado; $6 \%$ alegaram que a frequência dos odores sofre variações; e, os $6 \%$ restantes, correspondem àqueles que não identificaram odor em tempo algum.

Já para o Grupo II (até 10 s.m.), as respostas foram: 39\% disseram que a noite é o pior período; $36 \%$ acham que o período mais crítico é a tarde; $13 \%$ afirmaram ser o dia todo; $6 \%$ não se queixaram de odor algum; $3 \%$ indicaram o período da manhã; e, $3 \%$ afirmaram que varia muito. 
Entre o Grupo III (acima de 10 s.m.), as respostas obtidas foram: 43\% apontaram a tarde como o período crítico; $27 \%$ disseram ser o período da noite; $10 \%$ alegaram ser o dia todo; $10 \%$ afirmaram que varia muito; $5 \%$ indicaram o periodo da manhã; e, os restantes $5 \%$ não identificaram odor algum relacionado à estação de tratamento.

Verifica-se pelas porcentagens que os períodos mais críticos apontados pelos grupos são: tarde e noite. De fato, os odores parecem aumentar de intensidade ao final da tarde e começo da noite.

A FIGURA 8.20 aponta o comportamento dos grupos considerados frente ao indicador 6 - percepção de fatores agravantes.

FIGURA 8.20 - Renda Familiar X Percepção de fatores agravantes

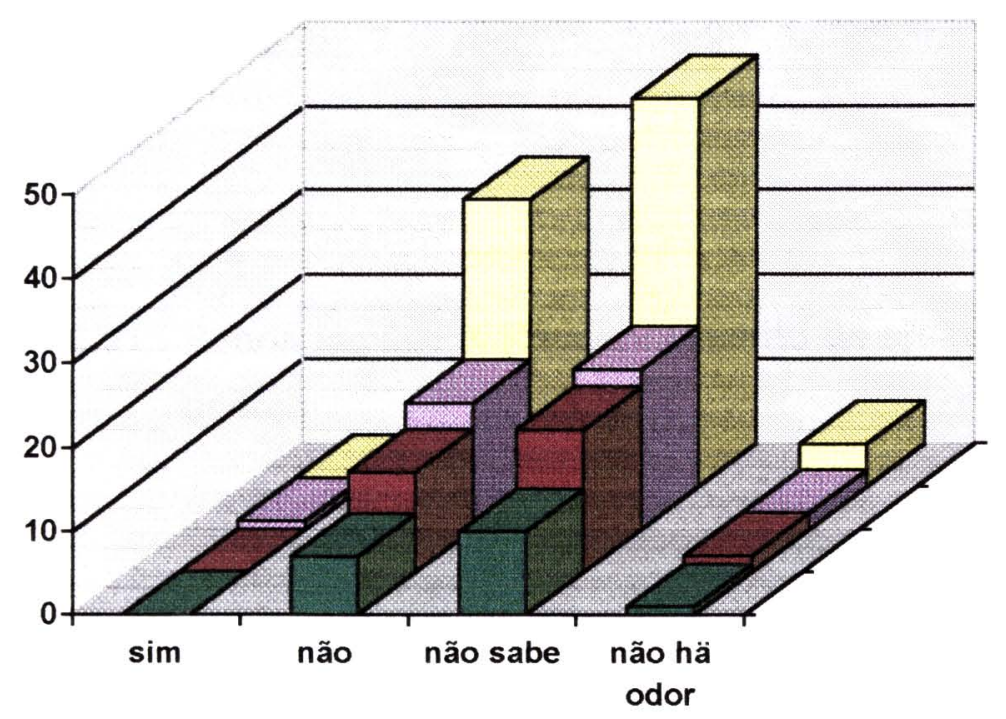

$\square$ até $5 \mathrm{sm}$ $\square$ até $10 \mathrm{sm}$ $\square$ ac. $10 \mathrm{sm}$ 口Total

Quanto ao indicador 6, o Grupo I (até 5 s.m.) apresentou as seguintes respostas: $56 \%$ não souberam afirmar com certeza; $38 \%$ não associaram nenhuma interferência externa contribuindo para o agravar a proliferação de 
odores; e os restantes $6 \%$ não se queixaram de odor algum relacionado à ETE - Piracicamirim.

No Grupo II (até 10 s.m.), as respostas dividiram-se assim: 55\% disseram não saber como responder à pergunta; 39\% afirmaram não existir interferência externa agravando o problema; e, 6\% continuaram afirmando desconhecer o problema de odores da estação.

Já para o Grupo III (acima de 10 s.m.), as respostas foram: 51\% não se julgaram capazes de responder à questão formulada; $41 \%$ não associaram nenhuma interferência externa; $5 \%$ não se queixaram do problema em momento algum; e, 3\% responderam que sim, existe interferência externa agravando mais o problema da proliferação de odores.

Mais uma vez, constata-se que não houveram grandes discrepâncias nas respostas dos diferentes grupos de renda considerados.

Finalmente, a FIGURA 8.21 analisa o comportamento da variável 3 em face do indicador 7 - reconhecimento de efeitos da exposição aos odores.

FIGURA 8.21 - Renda familiar X Reconhecimento de efeitos da exposição aos odores

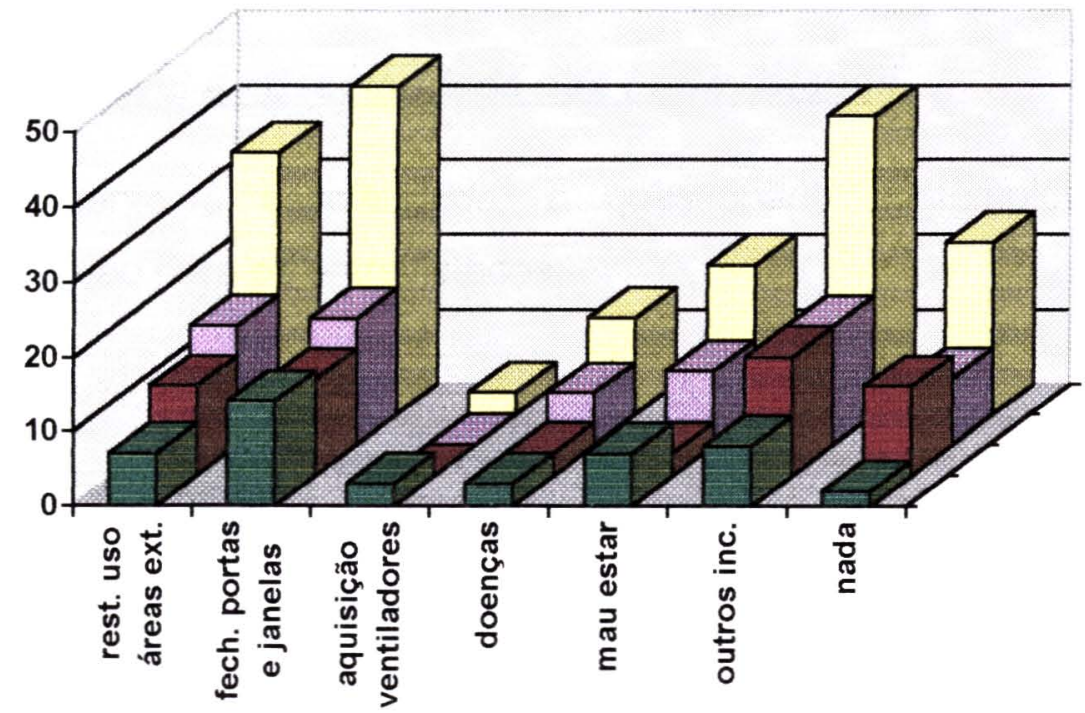


No que se refere aos efeitos da exposição aos odores, o Grupo I (até 5 s.m.) respondeu da seguinte forma: $78 \%$ afirmaram já terem fechado portas e janelas na tentativa de "barrar" a entrada do mau cheiro em suas residências; $44 \%$ indicaram outros efeitos diversos aos apresentados pelo questionário; $39 \%$ apresentaram restrições no uso de seus jardins e quintais; $39 \%$ queixaram-se de mau estar; $17 \%$ de doenças respiratórias e alergias; $17 \%$ alegaram ter sido necessária a compra de ventiladores; e, $11 \%$ não indicaram efeito algum

Quanto ao Grupo II (até 10 s.m.), as respostas dividiram-se em: $52 \%$ apresentaram efeitos diversos aos contemplados pelas alternativas do questionário (principalmente vetores); $42 \%$ já tiveram que fechar portas e janelas; $39 \%$ tiveram restrições no uso das áreas externas de suas casas; $39 \%$ não apontaram efeito algum; $10 \%$ queixaram-se de doenças respiratórias e alergias; e, $10 \%$ de mau estar.

As opiniões do Grupo III (acima de 10 s.m.) foram: 46\% alegaram já terem fechado portas e janelas devido aos odores; $43 \%$ apresentaram restrições no uso de áreas externas às suas residências; $43 \%$ indicaram efeitos diversos aos apresentados no questionário; $27 \%$ queixaram-se de mau estar; $24 \%$ não associaram nenhum efeito à proliferação de odores; $19 \%$ queixaram-se de doenças respiratórias e alergias relacionadas ao problema.

\section{Variável 4-Escolaridade dos Entrevistados}

Quanto à escolaridade, o questionário contemplou a seguinte classificação para os entrevistados:

- Analfabeto:

- $1^{\circ}$ grau incompleto: 
- $1^{\circ}$ grau completo;

- $2^{\circ}$ grau incompleto

$2^{\circ}$ grau completo

- Superior incompleto;

- Superior completo;

pós-graduação

Todavia, nenhum entrevistado se enquadrou na categoria de analfabeto e apenas 04 apresentaram-se com pós-graduação. Visando facilitar a análise das respostas obtidas, sem comprometer o estudo do comportamento da variável escolaridade, propõem-se a seguinte reclassificação em niveis:

$\checkmark$ Elementar - $\quad 1^{\circ}$ grau incompleto

30 entrevistados $=35 \%$

$\checkmark$ Básico - de $1^{\circ}$ grau completo até $2^{\circ}$ grau incompleto 29 entrevistados $=34 \%$.

$\checkmark$ Médio $\quad-\quad$ de $2^{\circ}$ grau completo até superior incompleto 19 entrevistados $=22 \%$.

Superior - de superior completo até pós-graduação 08 entrevistados $=9 \%$ 
A FIGURA 8.22 apresenta o comportamento da variável escolaridade frente ao indicador conhecimento (ou não) do órgão de saneamento local indicador 1.

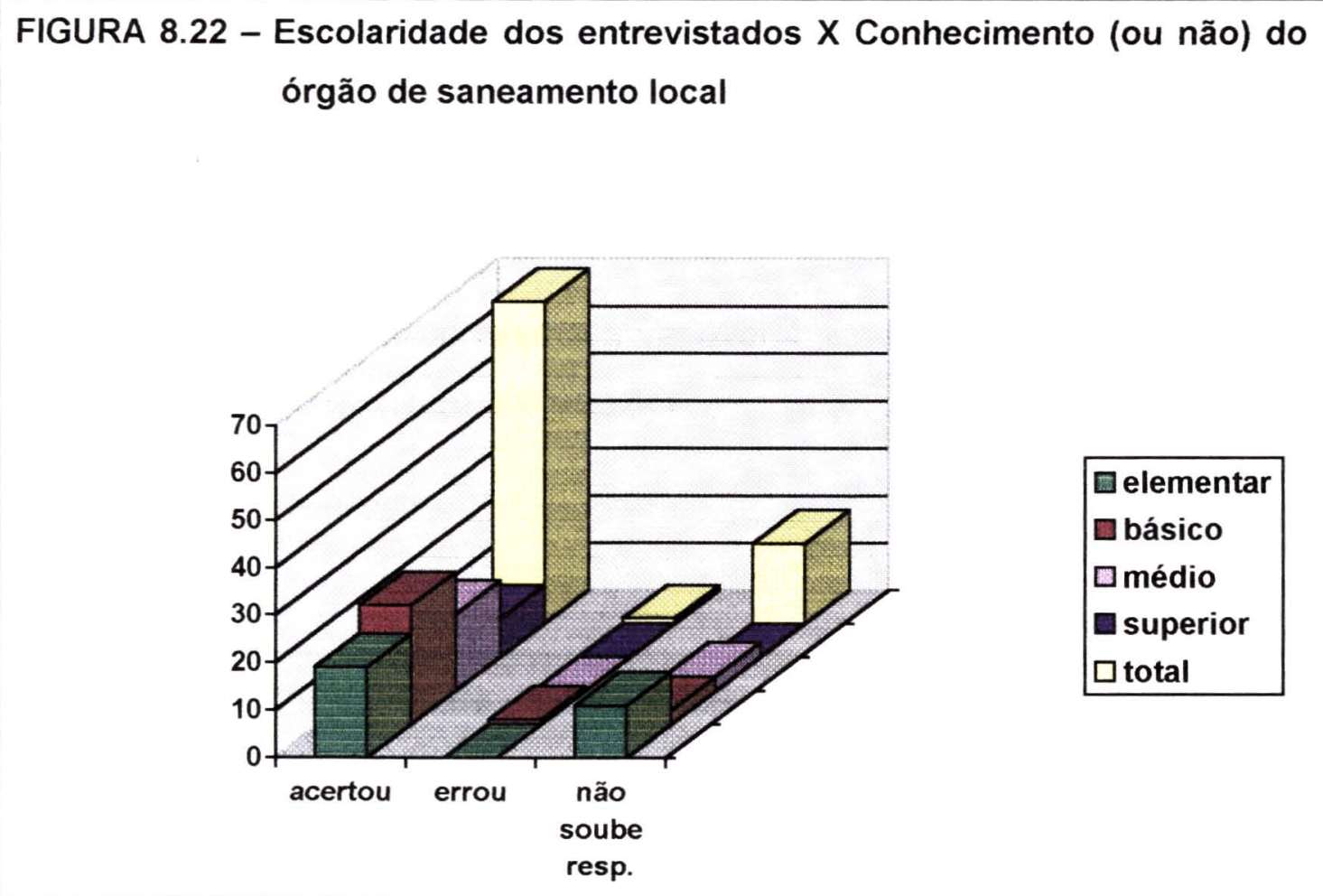

Pela análise dos dados apresentados na FIGURA 8.22, têm-se que as respostas ficaram assim divididas, nos diferentes níveis de escolaridade considerados:

Elementar - 63\% acertaram ao identificar o SEMAE como o órgão de saneamento local; e, 17\% não souberam responder à pergunta.

Básico - 86\% responderam corretamente; $10 \%$ não souberam responder; e, 4\% erraram ao apontar o nome do responsável pelos serviços de saneamento. 
Médio - $84 \%$ de acertos; e, $16 \%$ de entrevistados que declararam não saber como responder à questão.

Superior - $100 \%$ dos entrevistados acertaram ao apontar o SEMAE como o órgão responsável pelos serviços de saneamento de Piracicaba.

A identificação do responsável pelo tratamento de esgotos, apresentou uma tendência de crescimento acompanhando o aumento da escolaridade, a não ser pelo pequeno desvio no nível médio (quando a porcentagem de acertos mostrou-se menor do que no nível básico).

A FIGURA 8.23 apresenta a variável 4 em relação ao indicador 2 opinião sobre a disposição dos esgotos.

FIGURA 8.23 - Escolaridade dos entrevistados X Opinião sobre a disposição dos esgotos

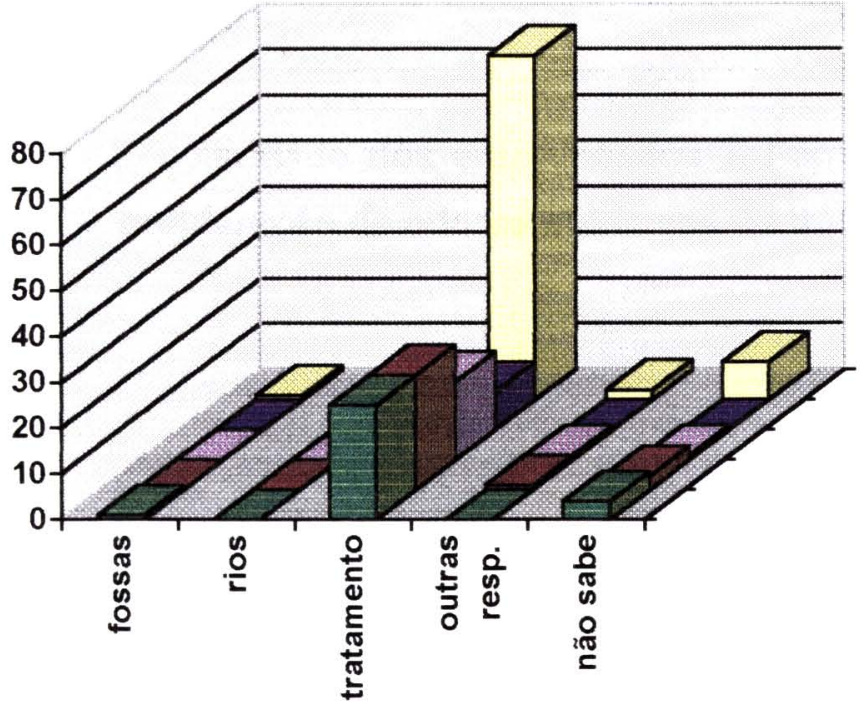

Gelementar

Gásico

$\square$ médio

superior

$\square$ total

O comportamento dos diferentes niveis de escolaridade considerados frente à opinião acerca da destinação final dos esgotos foi: 
Elementar - $83 \%$ a favor do tratamento; $13 \%$ não souberam responder; e, $4 \%$ apontaram as fossas como melhor alternativa.

Básico - 86\% escolheram o tratamento como melhor solução; $10 \%$ não souberam como responder à questão; e, 4\% deram outras alternativas diferentes das consideradas pelo questionário

Médio - 90\% indicaram o tratamento como melhor alternativa; $5 \%$ deram outras respostas; e, 5\% não souberam responder.

Superior - 100\% apontaram o tratamento como melhor solução para os esgotos sanitários.

Em relação ao indicador 2, observa-se que quanto maior a escolaridade do entrevistado, maior a sua conscientização acerca da importância do tratamento de esgotos.

Na FIGURA 8.24, estuda-se a variável escolaridade em face ao indicador 3 - percepção do impacto da proliferação de odores ofensivos do tratamento de esgotos.

FIGURA 8.24 - Escolaridade dos entrevistados X Percepção do impacto da proliferação de odores ofensivos do tratamento de esgotos

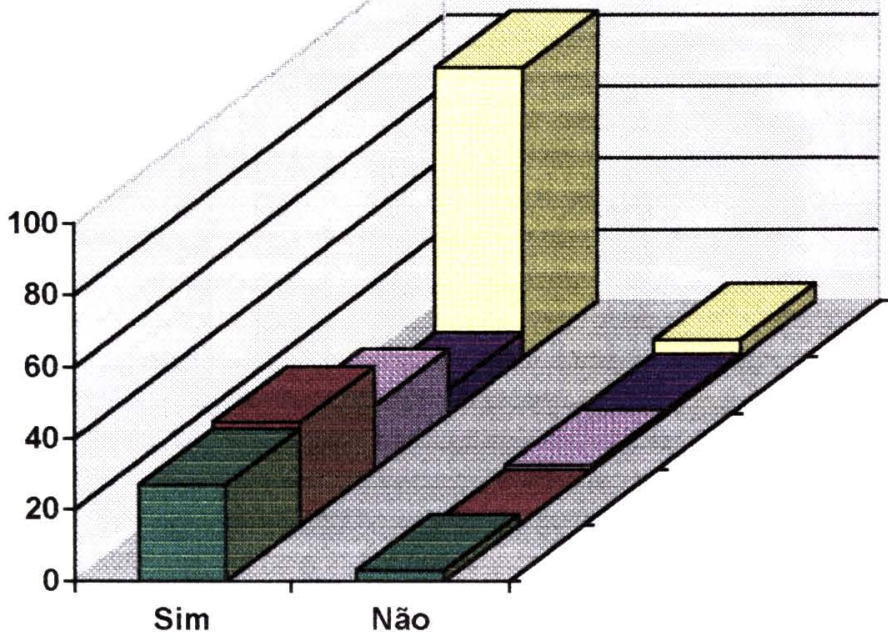

Delementar

口 básico

médio

vuperior

$\square$ total 
Quanto à percepção do impacto, as respostas dividiram-se:

Elementar - 90\% queixaram-se dos odores; e, $10 \%$ não os perceberam em nenhuma ocasião.

Básico - 100\% dos entrevistados apresentaram queixas relativas aos odores do tratamento de esgotos.

Médio - 95\% queixaram-se do problema; e, 5\% não identificaram odores associados à ETE.

Superior - $88 \%$ perceberam os odores ofensivos; e, $12 \%$ não se queixaram do problema.

Para este indicador, o que se pode observar, é que entre os diferentes niveis de escolaridade considerados houveram bastante variações nas respostas fornecidas.

Com a FIGURA 8.25, tem-se a apresentação dos resultados obtidos com a variável escolaridade em face ao indicador 4 - identificação da presença de odores ao longo do ano.

FIGURA 8.25 - Escolaridade do entrevistado X Identificação da presença de odores ao longo do ano

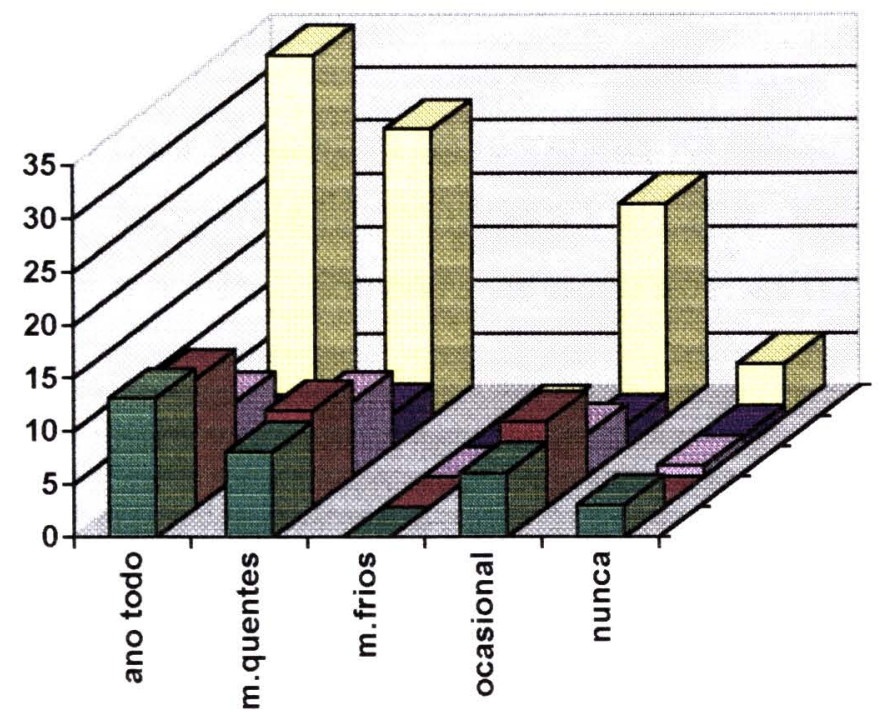

Gelementar

básico

$\square$ médio

a superior

$\square$ total 
Os resultados quanto à presença de odores ao longo do ano foram os que se seguem:

Elementar - $43 \%$ afirmaram que os odores estão presentes o ano todo; $27 \%$ disseram que eles estão presentes apenas nos meses quentes; $20 \%$ alegaram se tratar de um problema ocasional; e, os restantes $10 \%$ não identificaram odor em tempo algum associado à estação.

Básico - $41 \%$ disseram que os odores estão presentes 0 ano todo, $31 \%$ associaram sua presença aos meses quentes; e, $28 \%$ afirmaram que eles estão presentes apenas ocasionalmente.

Médio - 37\% identificaram a presença dos odores durante todo o ano; $37 \%$ afirmaram que eles estão presentes nos meses quentes; $21 \%$ afirmaram ser um problema ocasional; e, $5 \%$ nunca perceberam odores relacionados à ETE - Piracicamirim.

Superior - $37 \%$ afirmaram que os odores estão presentes durante os meses quentes; $25 \%$ alegaram que sua presença é durante todo o ano; $25 \%$ disseram ser um problema ocasional; e, $13 \%$ não se queixaram de odores.

Nota-se que a sequência de respostas foi quase a mesma para todos os niveis de escolaridade considerados: ano todo, meses quentes, ocasionalmente e nunca - sofrendo variação apenas no nivel superior. 
$\mathrm{Na}$ FIGURA 8.26, encontra-se o comportamento da variável escolaridade em face do indicador 5 - identificação dos odores ao longo do dia.

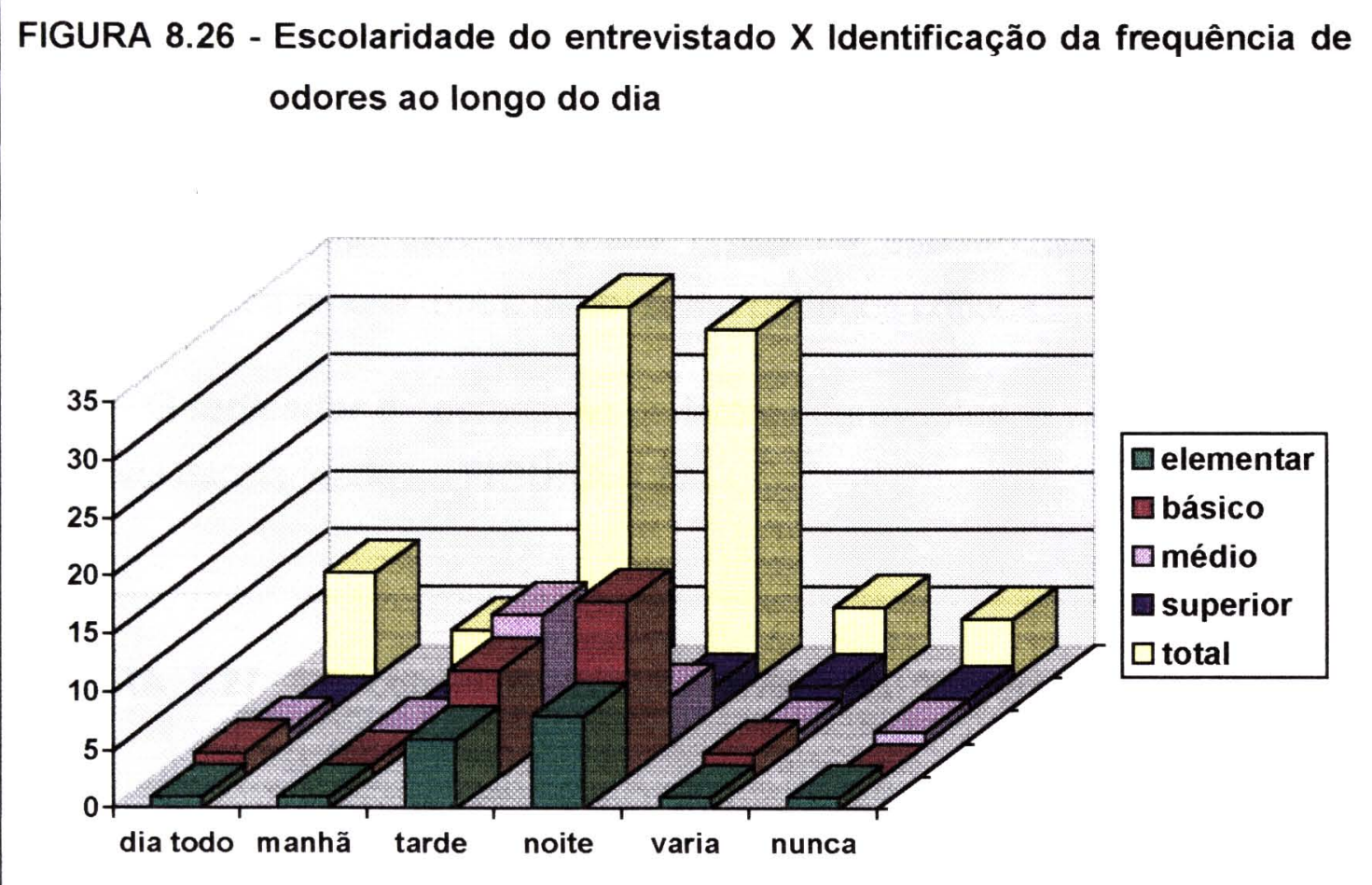

De acordo com o nível de escolaridade, as respostas acerca da identificação da frequência de odores ao longo do dia, foram:

Elementar - 30\% apontaram o período da noite como o mais crítico; $30 \%$ afirmaram ser a tarde; $20 \%$ disseram ser o dia todo; $10 \%$ não se queixaram de odores; $7 \%$ disseram que pela manhã, o quadro é pior; e, $3 \%$ afirmaram que varia muito.

Básico - $52 \%$ afirmaram que a noite é o período mais crítico; $31 \%$ disseram que a tarde é pior; $7 \%$ consideraram que o problema persiste $\circ$ dia todo; $7 \%$ alegaram que varia muito; e, $3 \%$ identificaram o período da manhã, como sendo o período crítico. 
Médio - 58\% disseram que o periodo mais crítico é o da tarde; $22 \%$ consideraram ser o período da noite; $5 \%$ afirmaram ser o dia todo; $5 \%$ alegaram ser o periodo da manhã; $5 \%$ disseram variar muito; e, $5 \%$ não se queixaram de odores.

Superior - 37\% afirmaram que o período crítico é a tarde; $25 \%$ disseram ser a noite; $25 \%$ garantiram que varia muito; e $13 \%$ não apresentaram queixa de odores associados ao tratamento de esgotos.

As respostas dos diferentes níveis de escolaridade alternaram-se apontando ora a noite, ora a tarde, como periodos críticos.

O indicador 6 - percepção de fatores agravantes, é estudado frente à variável escolaridade na FIGURA 8.27.

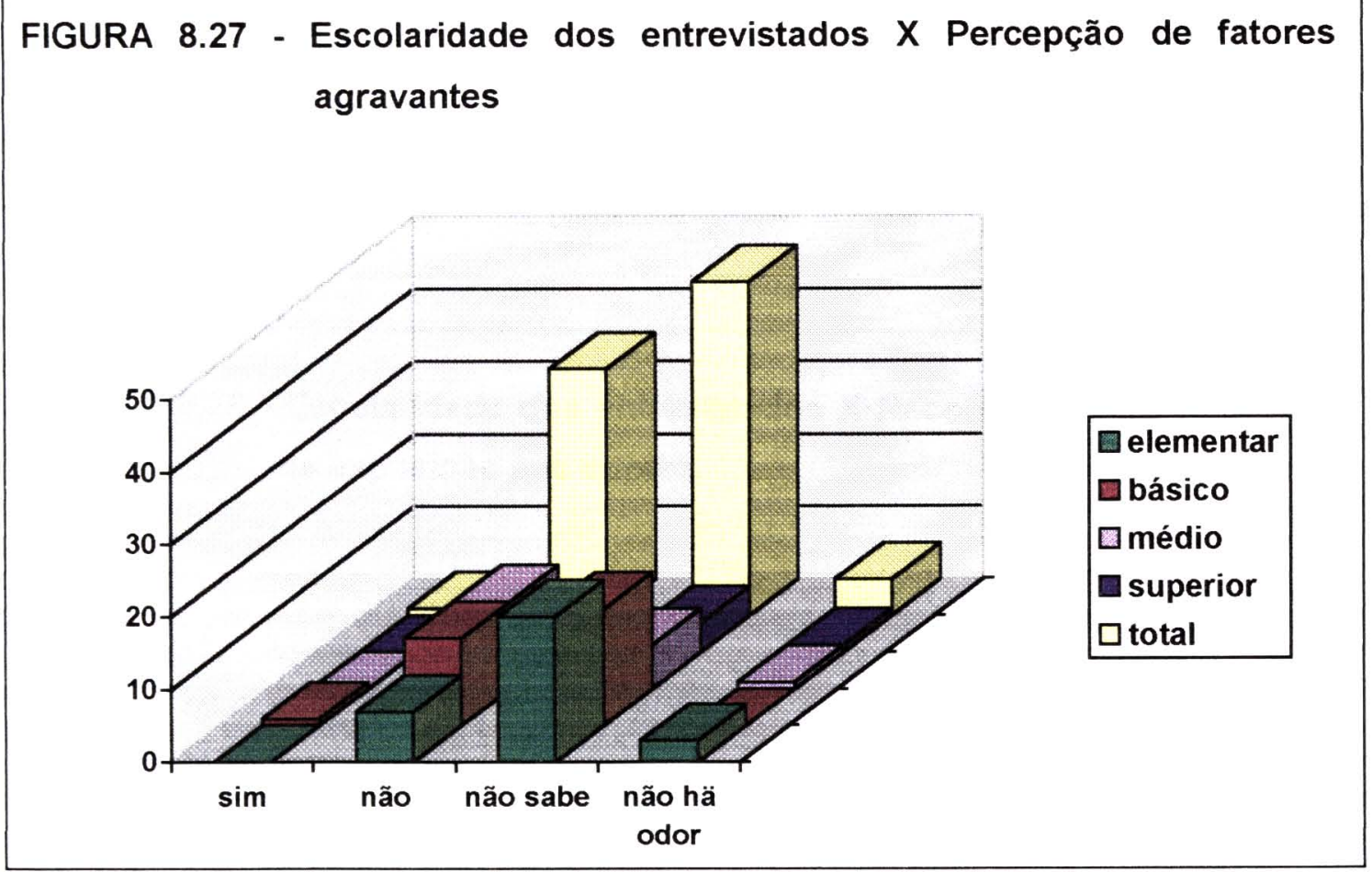

Os resultados obtidos para os diferentes niveis considerados dividemse em: 
Elementar - $67 \%$ não souberam afirmar se existe interferência externa contribuindo para agravar o problema dos maus odores; $23 \%$ afirmaram que não existe interferência; e, $10 \%$ não se queixaram do problema.

Básico - 55\% não souberam responder à questão; $41 \%$ afirmaram que não há interferência externa; e, 4\% disseram que há interferência externa agravando o problema dos odores.

Médio - 63\% julgaram não haver interferência externa; $32 \%$ não souberam como responder à pergunta; e, 5\% continuaram sem apresentar queixa relativa à proliferação de odores.

Superior - 50\% afirmaram não saber como responder à questão; $37 \%$ disseram não haver interferência externa; e, 13\% persistiram não tendo queixas quanto à odores ofensivos.

Na FIGURA 8.28, apresenta-se o comportamento da variável escolaridade frente ao indicador 7 - reconhecimento de efeitos da exposição aos odores.

FIGURA 8.28 - Escolaridade dos entrevistados X Reconhecimento de efeitos da exposição aos odores

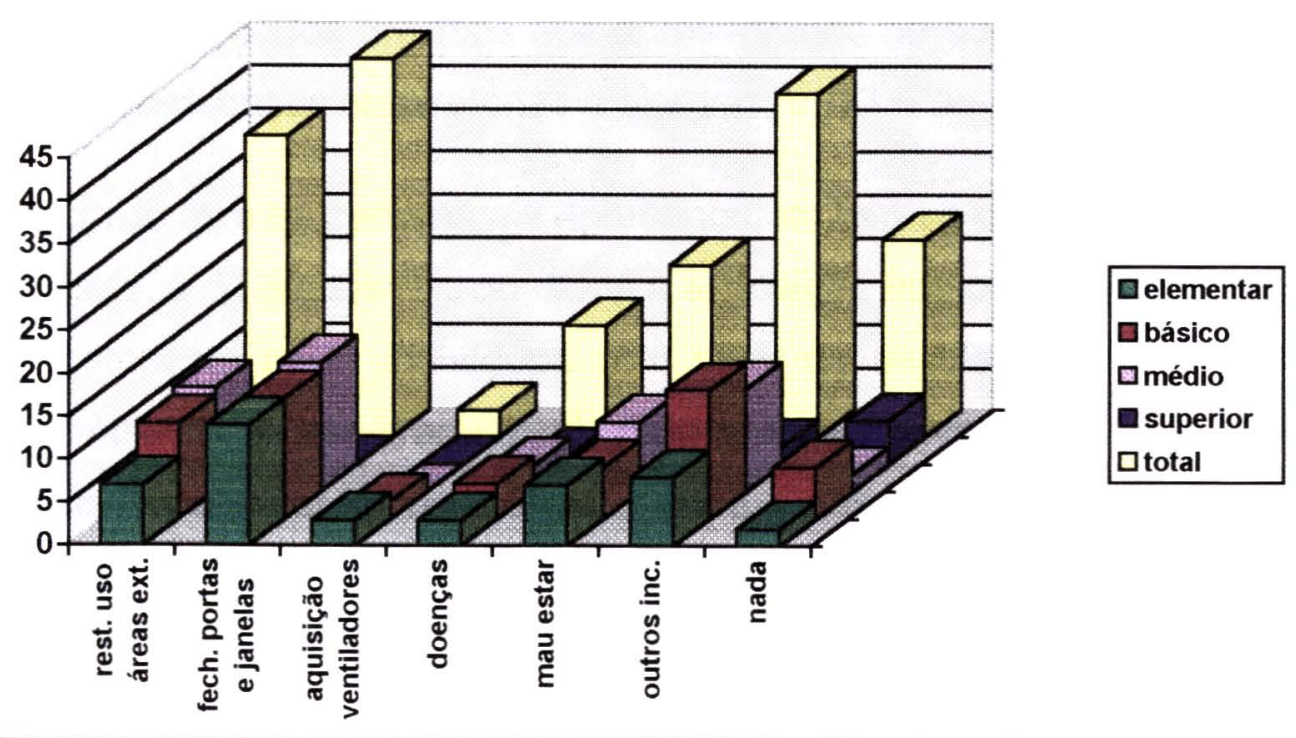


No reconhecimento de efeitos da exposição aos odores ofensivos, as respostas foram distribuídas da seguinte maneira:

Elementar - 50\% afirmaram que já tiveram que fechar portas e janelas devido ao problema; $40 \%$ alegaram restrições no uso das áreas externas à residência; $37 \%$ apresentaram outros incômodos diversos aos listados pelo questionário; $33 \%$ não associaram nenhum efeito aos odores; $17 \%$ queixaram-se de mau estar; $17 \%$ de doenças respiratórias e alergias; $e$, $3 \%$ disseram ter sido necessária a aquisição de ventiladores.

Básico - 52\% apresentaram outros incômodos diferentes dos relacionados pelo questionário; $48 \%$ afirmaram já terem fechado janelas e portas para tentar "escapar" dos odores; $38 \%$ disseram ter sofrido restrições no uso de suas áreas externas (jardins e quintais); $21 \%$ queixaram-se de mau estar; $21 \%$ não reconheceram nenhum efeito da exposição aos odores; $14 \%$ queixaram-se de doenças respiratórias e atergias; $7 \%$ tiveram que adquirir ventiladores para minorar o desconforto causado pelos odores.

Médio - 79\% já fecharam portas e janelas por causa dos odores ofensivos; $63 \%$ apresentaram restrições no uso de quintais e jardins; $63 \%$ indicaram outros incômodos diversos: $42 \%$ queixaram-se de mau estar, $16 \%$ de doenças respiratórias e alergias; e, 10\% não reconheceram efeito algum decorrente da proliferação de odores.

Superior - $63 \%$ não apresentaram efeito algum associado aos odores; $25 \%$ indicaram incômodos diversos aos apresentados no questionário; $13 \%$ queixaram-se de doenças respiratórias e alergias; e, 13\% de mau estar.

De acordo com os percentuais apresentados, tem-se que o grupo que menos se queixou de efeitos relacionados à exposição aos odores ofensivos foi aquele composto pelos individuos com nivel de escolaridade superior (superior completo até pós-graduação). Este resultado explica-se pelo fato desses entrevistados serem os menos expostos aos odores ofensivos, já que passam a maior parte do tempo afastados de suas residências: durante 
os dias úteis, permanecem envolvidos em suas atividades profissionais e escolares; e, nos finais de semana, como muitos deles são provenientes de cidades vizinhas, aproveitam para retornar às cidades de origem.

\section{Variável 5 - Procedência da Familia (Cidade de Origem)}

Através do questionário, buscou-se analisar o vínculo dos entrevistados com o lugar onde vivem, para tanto, os mesmos foram inquiridos acerca do tempo de moradia no imóvel (anos); procedência (urbana ou rural); e, cidade de origem (Piracicaba ou outra localidade).

A importância da análise da procedência da familia, diz respeito principalmente, ao fato de que as pessoas nascidas e criadas em um determinado lugar tendem à maximizar as caracteristicas positivas de sua cidade ou região e minimizar as negativas, e é nisso que consiste o vinculo afetivo que buscou-se abordar com o estudo desta variável.

Os resultados obtidos apontam um tempo de moradia em torno de 13 anos, para a média das familias; $85 \%$ destas familias procedem da zona urbana. contra apenas $15 \%$ da zona rural; e, $66 \%$ delas são naturais de Piracicaba, contra $34 \%$ que vieram de outras localidades.

Para a análise da procedência da família, em termos de sua cidade de origem, elas forma divididas da seguinte forma:

$\begin{array}{lll}\checkmark \text { Migrantes } & - & 29 \text { entrevistados }(34 \%) \text {; } \\ \checkmark \text { Não Migrantes } & - & 57 \text { entrevistados }(66 \%) \text {. }\end{array}$

De posse destes dados pretiminares, pode-se passar à análise da variável 5 em relação ao indicador 1 - conhecimento (ou não) do órgão de saneamento local - FIGURA 8.29 
FIGURA 8.29 - Procedência da família X Conhecimento (ou não) do órgão de saneamento local

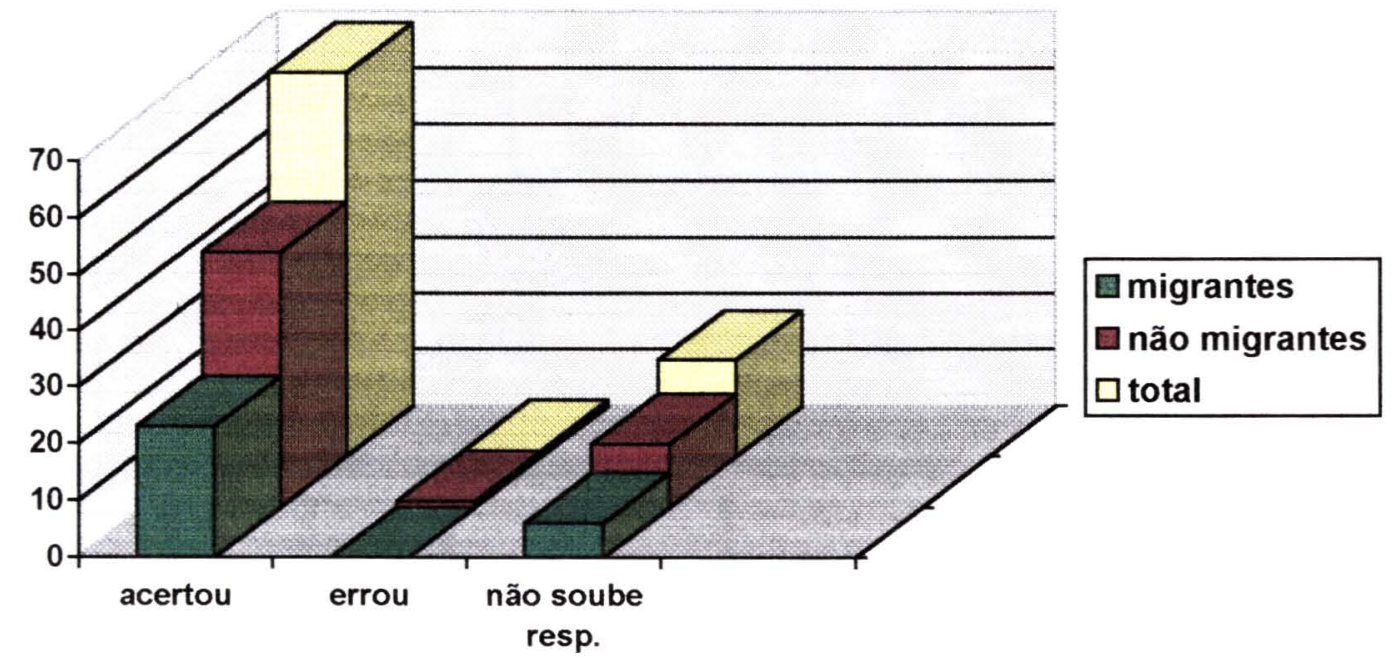

Quanto ao indicador 2, as respostas dividiram-se em:

Migrantes - $79 \%$ indicaram corretamente 0 SEMAE como 0 responsável pelos serviços de tratamento de esgotos em Piracicaba; e, 21\% não souberam responder à pergunta.

Não Migrantes - 79\% acertaram ao apontar o órgão de saneamento local; $19 \%$ não souberam como responder; e, $2 \%$ erraram em suas respostas.

O mesmo percentual de migrantes e não migrantes demonstraram seu conhecimento acerca do órgão responsável pelo saneamento local. Os resultados só divergiram entre os que não souberam responder à questão formulada e o pequeno percentual dos que erraram a resposta (apenas para o grupo dos não migrantes).

A FIGURA 8.30 apresenta o comportamento da variável estudada frente ao indicador 2 - opinião sobre a disposição dos esgotos. 


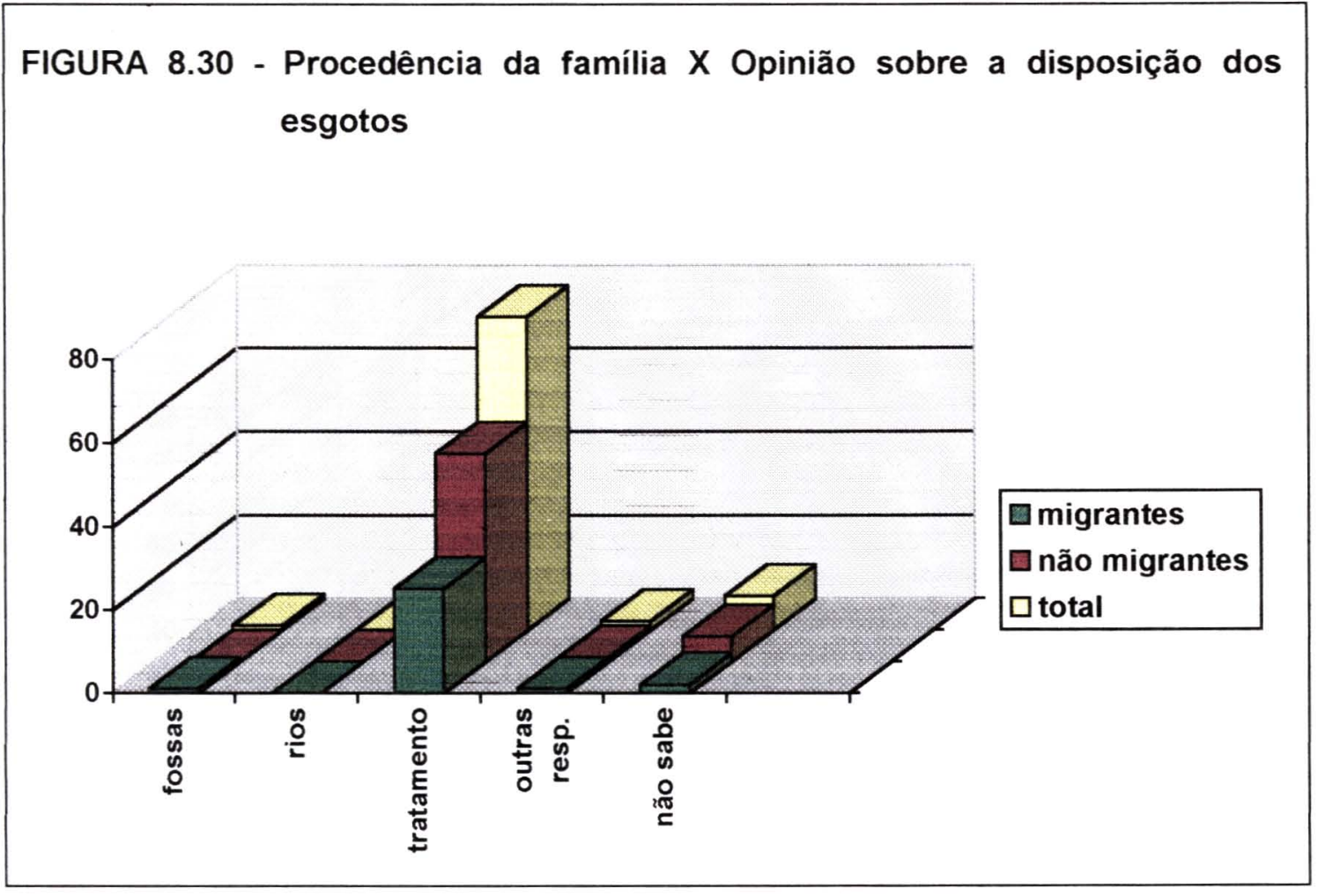

As respostas de migrantes e não migrantes relacionadas à opinião sobre a destinação final dos esgotos, foram as seguintes:

Migrantes $-86 \%$ são a favor do tratamento como melhor alternativa; $8 \%$ não souberam como responder à pergunta; $3 \%$ apontaram as fossas como solução; e, 3\% apresentaram respostas diversas das contempladas pelo questionário.

Não Migrantes - $88 \%$ apontaram o tratamento como solução para o problema; $10 \%$ não souberam responder; e, 2\% apresentaram outras respostas que não as do questionário.

Não houveram discrepâncias significativas quanto às respostas dos diferentes grupos considerados.

Na FIGURA 8.31, apresenta-se a variável 5 em relação ao indicador 3 - percepção do impacto da proliferação de odores ofensivos do tratamento de esgotos. 
FIGURA 8.31 - Procedência da família X Percepção do impacto da proliferação de odores ofensivos do tratamento de esgotos

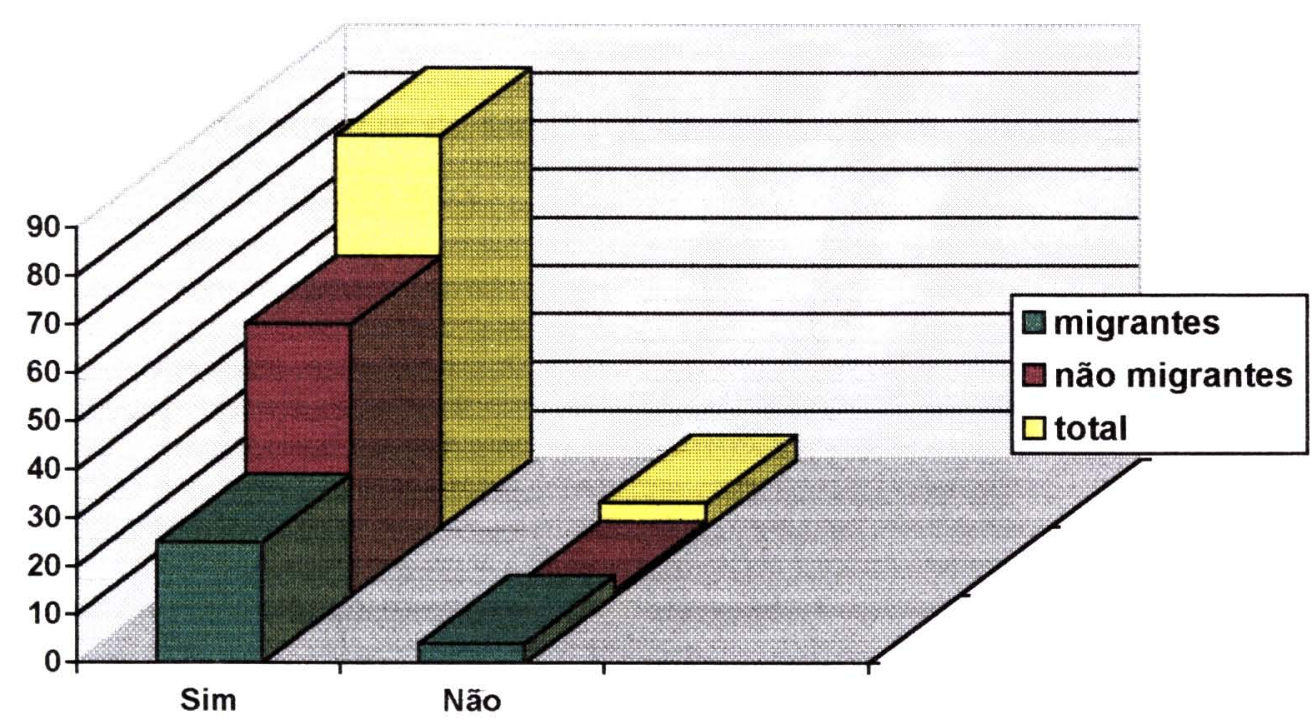

Quanto à percepção do impacto estudado, os grupos comportaram-se da seguinte forma:

Migrantes - $86 \%$ queixaram-se de maus odores do tratamento de esgotos; e, 14\% não identificaram odor algum.

Não Migrantes - $98 \%$ identificaram o impacto; e, $2 \%$ não se queixaram dele.

Pela análise dos percentuais, verifica-se que os "não migrantes" foram mais sensíveis à proliferação de odores do que os "migrantes". 
A FIGURA 8.32 traz o comportamento da variável 5 em relação ao indicador 4 - identificação da presença dos odores ao longo do dia.

\section{FIGURA 8.32 - Procedência da familia X Identificação da presença de odores} ao longo do ano

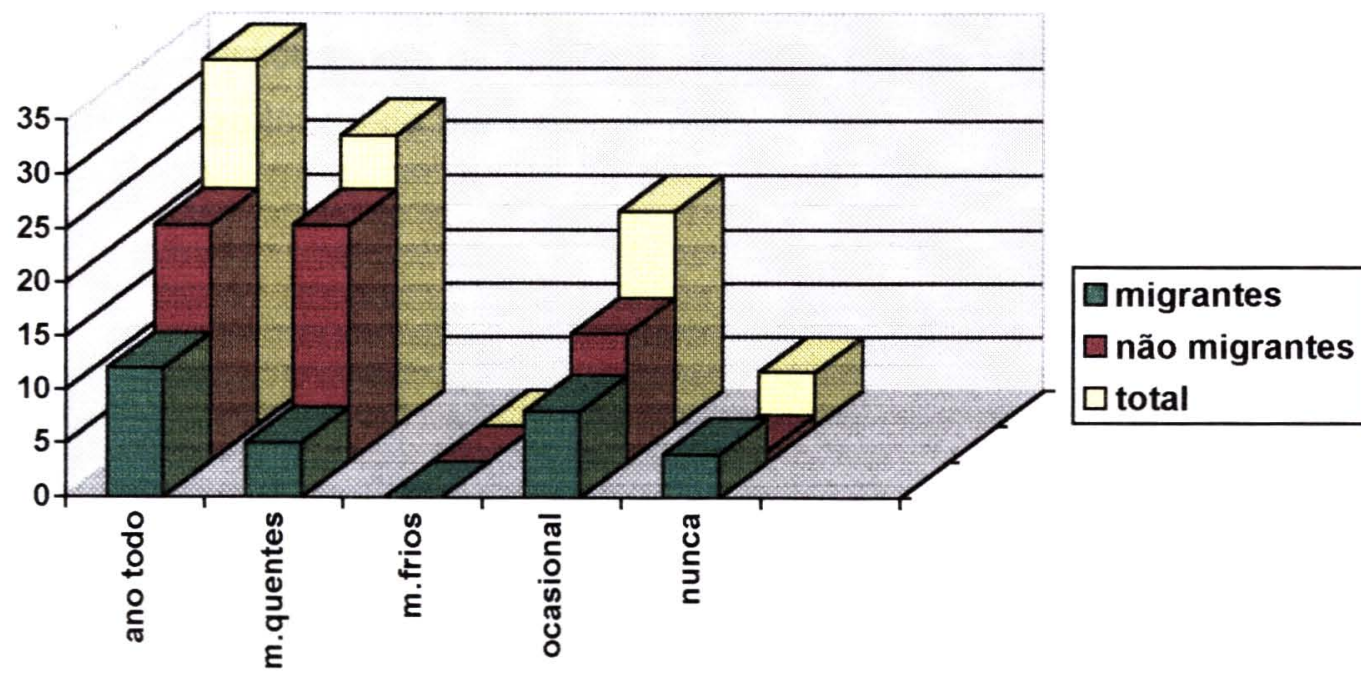

No que se refere à identificação da presença de odores ao longo do ano, as respostas dividiram-se desta maneira:

Migrantes $-41 \%$ indicaram a presença dos odores durante $\circ$ ano todo; $28 \%$ afirmaram tratar-se de um problema ocasional; $17 \%$ alegaram que a situação piora nos meses quentes; e, 14\% continuaram sem se queixar de odores ofensivos.

Não Migrantes - $39 \%$ afirmaram que os odores persistem durante todo o ano; $38 \%$ disseram que nos meses quentes é pior; $21 \%$ alegaram que é um problema ocasional; e, $2 \%$ não se queixaram de odor em tempo algum. 
A maioria, tanto entre os "migrantes" quanto entre os "não migrantes", aponta a proliferação de odores ofensivos do tratamento de esgotos como um problema que persiste durante todo $o$ ano.

Com a FIGURA 8.33, pode-se observar a variável 5 frente ao indicador 5 - identificação da frequência dos odores ao longo do dia.

\section{FIGURA 8.33 - Procedência da família X Identificação da frequência de odores ao longo do dia}

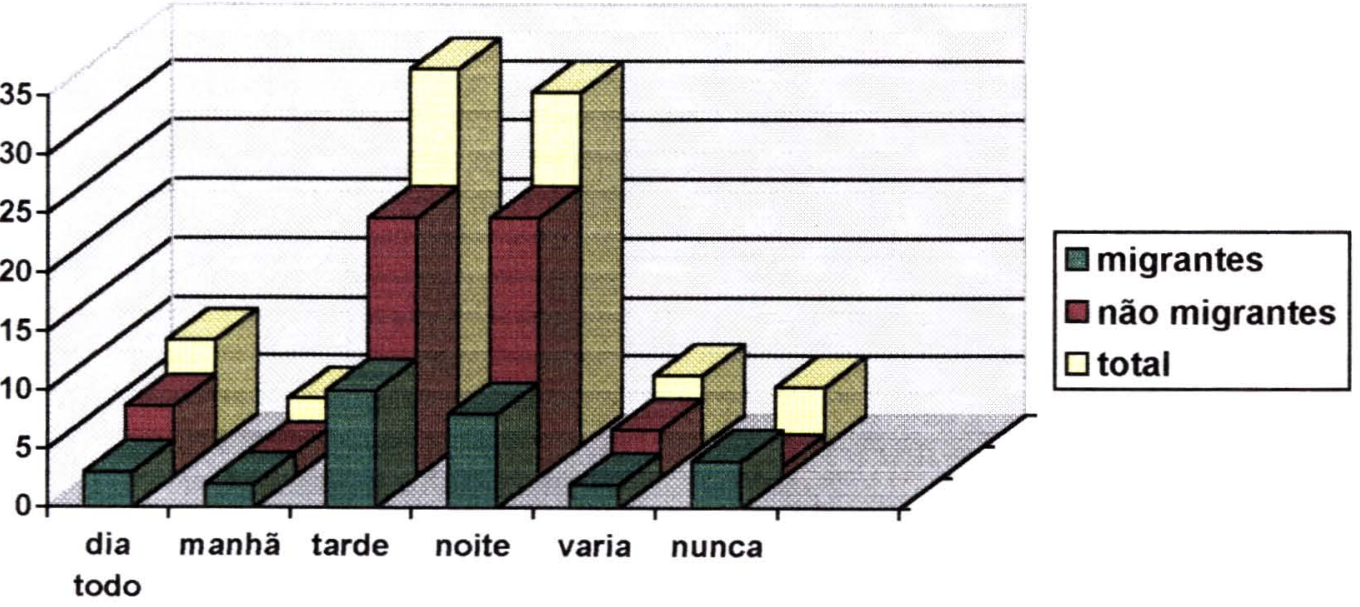

Quanto à frequência dos odores ao longo do dia, as opiniões dividiram-se em:

Migrantes - 34\% apontaram o período da tarde como o mais crítico; $28 \%$ afirmaram que a noite é pior; $14 \%$ não se queixaram de odor; $10 \%$ alegaram que os odores estão presentes o dia todo; $7 \%$ disseram que pela manhã é pior; e, $7 \%$ afirmaram que varia muito.

Não Migrantes - 39\% apontaram o período da tarde como sendo o período crítico; $39 \%$ afirmaram ser o período da noite; $10 \%$ disseram que os 
odores persistem o dia todo; $7 \%$ alegaram que varia muito; $3 \%$ afirmaram que o período da manhã é o pior; e, $2 \%$ não se queixaram de odor.

As respostas seguiram quase que a mesma sequência para ambos os grupos, e mesmo os percentuais não apresentaram grandes distorções.

A FIGURA 8.34 apresenta a variável 5 em face do indicador 6 percepção de fatores agravantes.

\section{FIGURA 8.34 - Procedência da família X Percepção de fatores agravantes}

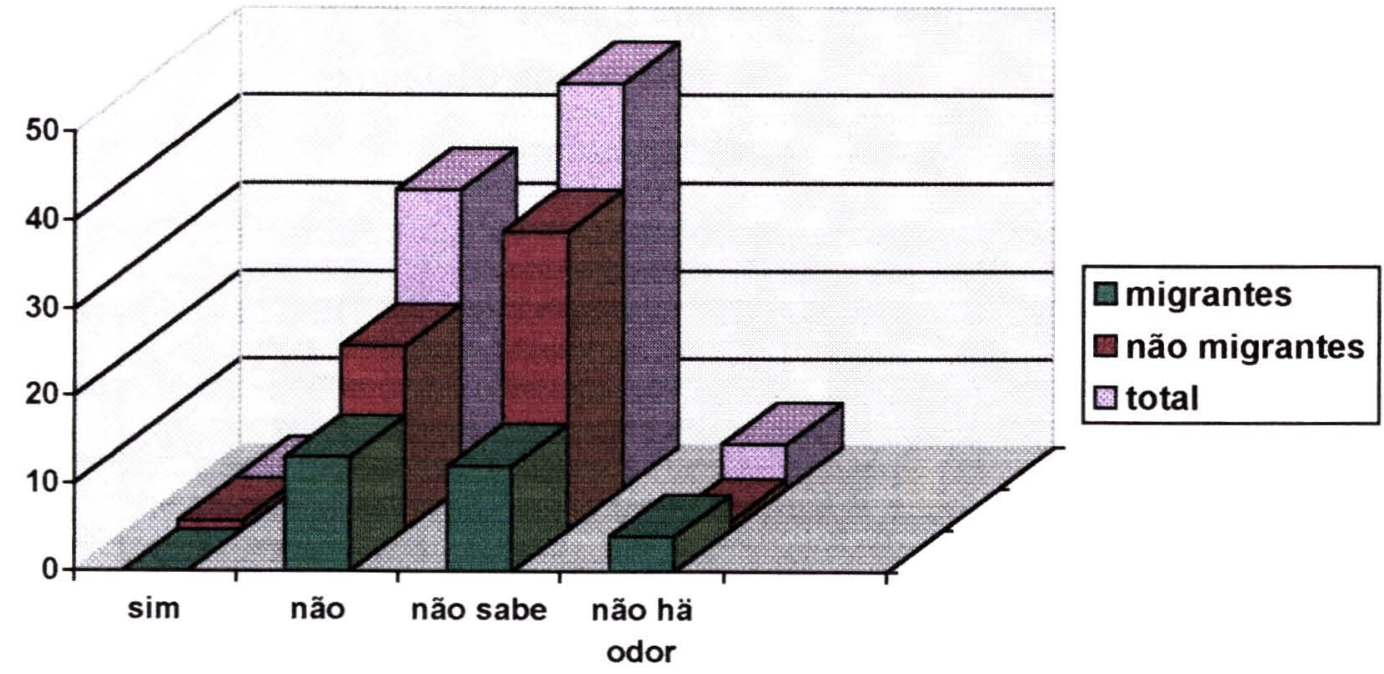

Em relação à identificação de fatores agravantes ao problema dos odores, os grupos considerados apresentaram as seguintes respostas:

Migrantes - 45\% afirmaram que não há interferência externa contribuindo para o agravamento do problema; $41 \%$ não souberam afirmar com certeza; e, $14 \%$ não se queixaram de odores.

Não Migrantes - 60\% não souberam afirmar com certeza; $36 \%$ disseram não haver interferência externa; $2 \%$ não se queixaram de odores 
ofensivos relacionados à estação; e, $2 \%$ alegaram a existência de fatores agravantes ao problema.

Nota-se maior cautela do grupo de "não migrantes" ao responder esta questão, preferindo não responder à responder sem ter certeza. Apesar de que somente por este grupo, houveram respostas alegando a existência de fatores externos contribuindo para agravar a proliferação de odores.

A FIGURA 8.35 finaliza a análise das variáveis frente aos indicadores considerados, ao apresentar o comportamento da variável 5 frente ao indicador 7 - reconhecimento de efeitos da exposição aos odores.

FIGURA 8.35 - Procedência da familia X Reconhecimento de efeitos da exposição aos odores

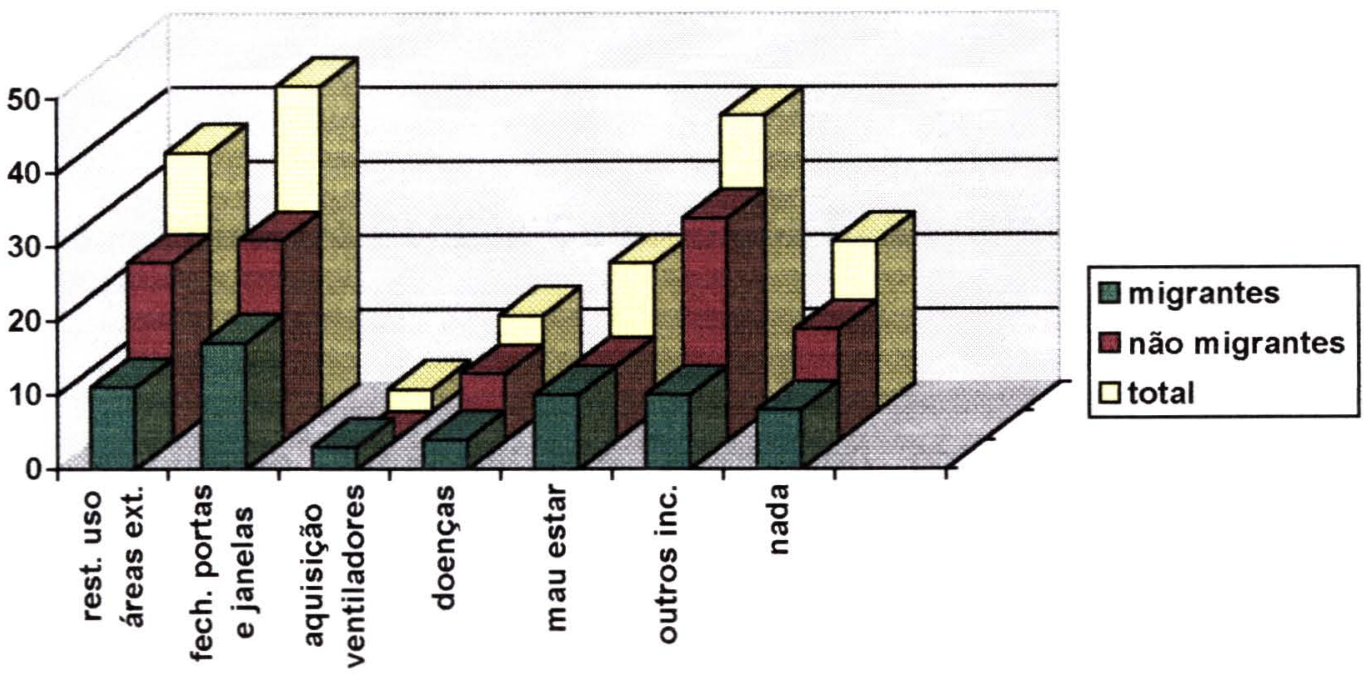

Da análise das respostas obtidas, têm-se os seguintes percentuais para cada grupo:

Migrantes - $59 \%$ já tiveram que fechar portas e janelas devido aos odores; $38 \%$ alegaram restrições no uso de áreas externas à residência, como jardins e quintais; $34 \%$ queixaram-se de mau estar; $34 \%$ apresentaram 
outros incômodos diversos aos relacionados pelo questionário; $28 \%$ não reconheceram efeito algum associado aos odores ofensivos; $14 \%$ queixaram-se de doenças respiratórias e alergias; e, 10\% disseram que tiveram necessidade de adquirir ventiladores para tentar amenizar $\sigma$ problema em seus lares.

Não Migrantes - $53 \%$ apresentaram incômodos diversos aos listados pelo questionário; $47 \%$ disseram que já fecharam portas e janelas por causa dos odores; $42 \%$ já sofreram restrições na utilização de suas área externas; $26 \%$ não apresentaram efeito algum; $18 \%$ queixaram-se de mau estar; $e$, $16 \%$ de doenças respiratórias e alergias.

Observa-se que a ordem de efeitos apontada por um grupo, não foi exatamente a mesma para o outro. Mas apesar disso, destacam-se o "hábito adquirido" do fechamento de portas e janelas, e as restrições de utilização de áreas externas, como os principais efeitos relacionados à proliferação de odores, segundo a percepção da população.

\subsection{Estrutura Política-Cultural dos Entrevistados}

A população estudada não apresentou grande disposição à participação em associações comunitárias, já que apenas $14 \%$ dos entrevistados afirmaram já terem tomado parte em movimentos desta ordem. Tal fato demonstra uma falta de mobilização em torno dos assuntos comuns do cotidiano de seus bairros (Jardim Brasília e Vila Independência), tais como reivinđicações públicas e manifestações populares.

Dentre os que participam de algum movimento, a maioria relaciona-se à movimentos religiosos, mas nestes não há nenhuma integração com política ou direitos civis 
No que se refere à política, têm-se $57 \%$ dos entrevistados que afirmam interesse pelo tema, contra $43 \%$ que preferem não tratar deste assunto

Entre os interessados por política, seu nivel de discussão encontra-se dividido da seguinte forma: $41 \%$ tratam deste assunto com os amigos; $37 \%$ discutern politica com os familiares; $17 \%$ entre os vizinhos; e, apenas $5 \%$ com os colegas de trabalho

Maiores informações acerca deste e dos outros parâmetros contemplados pelo questionário, encontram-se apresentadas no ANEXO 3 , ao final desta tese.

Ainda em relação à falta de mobilização comunitária, muitos dos entrevistados afirmaram saber de reuniōes realizadas entre os moradores e técnicos do SEMAE, para discutir a questão dos odores relacionados à ETE - Piracicamirim, as quais tiveram lugar no conjunto Posto de Saúde / Creche existente entre os dois bairros pesquisados (fotos no ANEXO 4)

Entretanto foram poucos os que afirmaram ter participado das reuniões, tanto entre os entrevistados do Jardim Brasília, quanto entre os entrevistados da Vila Independência. A principal alegação para o não comparecimento às reuniões foi a "falta de tempo".

\subsection{Percepção do Impacto em Relação à Localização das Residências}

Para uma melhor visualização da ETE e seu entorno, a FIGURA 8.36 apresenta um esquema sem escala, com a localização dos bairros pesquisados e demais vizinhos da estação 
FIGURA 8.36 - ETE - Piracicamirim e seu entorno

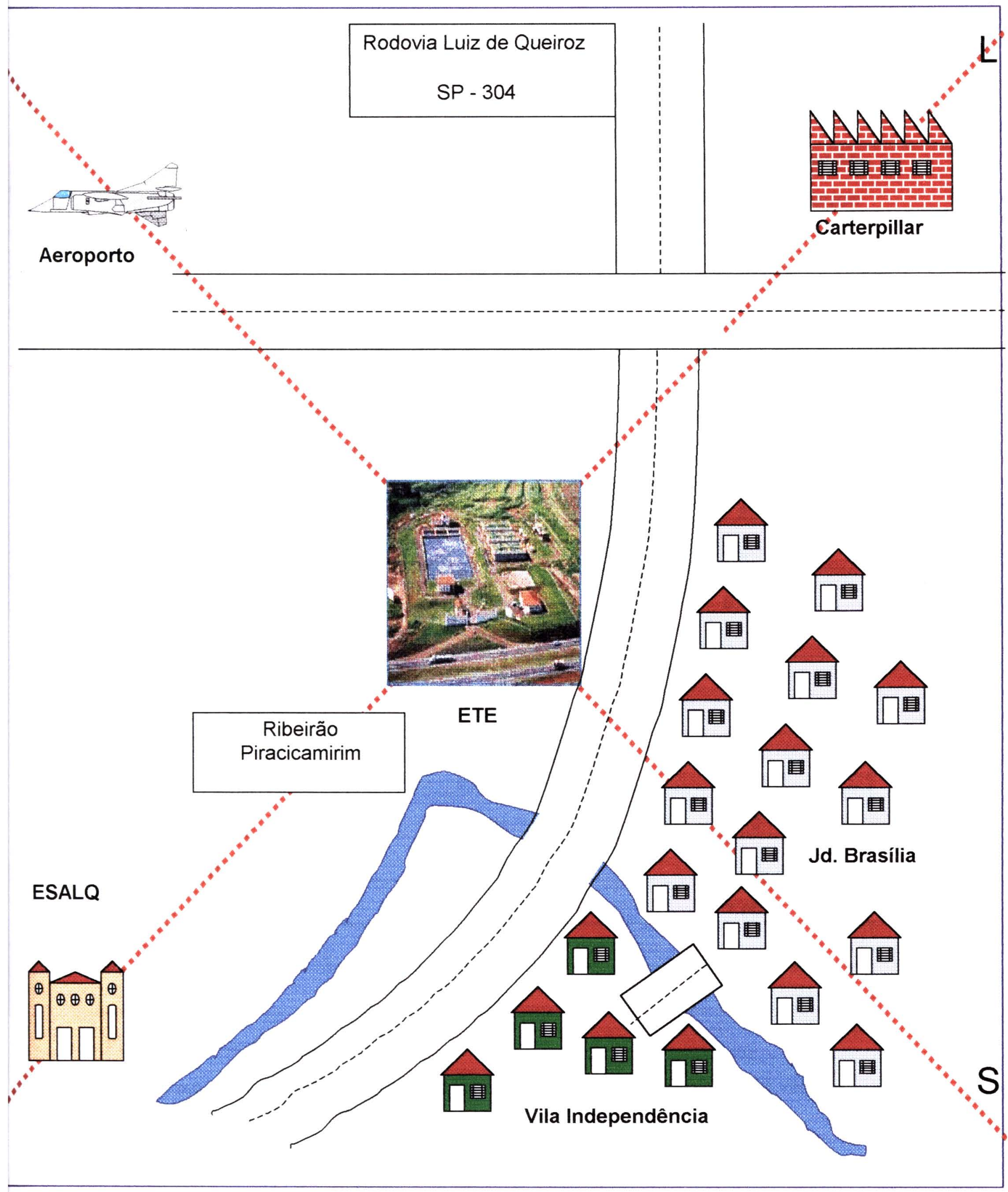


Pelo esquema da FIGURA 8.36 e fixando-se a ETE - Piracicamirim como centro de referência, têm-se ao norte o aeroporto de Piracicaba, ao sul o Jardim Brasília, à leste a empresa Caterpillar e à oeste a ESALQ-USP (Escola Superior de Agricultura Luiz de Queiroz da Universidade de São Paulo).

O QUADRO 8.1 apresenta dados mensais relativos à direção predominante e velocidade média dos ventos para o ano 2000 , coletados para a ETE - Piracicamirim por estagiários do SEMAE.

QUADRO 8.1 - Direção predominante e velocidade média dos ventos para os meses do ano 2000

\begin{tabular}{|c|c|c|}
\hline ANO 2000 & $\begin{array}{l}\text { DIREÇÃO PREDOMINANTE } \\
\text { DOS VENTOS }\end{array}$ & $\begin{array}{c}\text { VELOCIDADE MÉDIA } \\
(\mathrm{Km} / \mathrm{h})\end{array}$ \\
\hline Janeiro & Norte e Nordeste & 7,80 \\
\hline Fevereiro & Sudeste e Sul & 7,62 \\
\hline Março & Sudoeste & 8,40 \\
\hline Abril* & - & 6,00 \\
\hline Maio & Leste & 7,00 \\
\hline Junho & Sudeste & 6,80 \\
\hline Julho & Sul & 7,20 \\
\hline Agosto & Sudoeste & 8,40 \\
\hline Setembro & Noroeste & 9,10 \\
\hline Outubro & Leste & 7,90 \\
\hline Novembro & Nordeste & 7,60 \\
\hline Dezembro & Noroeste & 6,90 \\
\hline
\end{tabular}

Fonte: Relatórios SEMAE - Piracicaba.

* para o mês de abril/2000, não consta dos relatórios a direção predominante dos ventos. 
De posse dos dados apresentados na FIGURA 8.36 e no QUADRO 8.1, é possivel analisar, ainda que de uma maneira geral e simplificada, a proliferação dos odores ofensivos da ETE - Piracicamirim, também em função da localização dos seus vizinhos mais próximos.

Tem-se que os bairros residenciais Jardim Brasília e Vila Independência, localizam-se respectivamente ao sul e à sudoeste da estação, sendo que o primeiro estende-se também à sudeste.

Uma vez que a direção predominante dos ventos aponta de onde estes ventos estão vindo, podem ser traçadas algumas considerações a respeito do comportamento desta variável durante o ano em que foi efetuada a pesquisa de campo, bem como de suas implicações na dispersão dos odores da ETE - Piracicamirim.

Durante o ano 2000 , os ventos sopraram dos bairros para a estação durante os meses de fevereiro, março, junho, julho e agosto, ou seja, 5 meses naquele ano. Pode-se afirmar que durante estes meses, os ventos não contribuíram para a proliferação dos odores na direção dos dois bairros pesquisados, já que o seu sentido foi o oposto.

No período de aplicação do questionário que compreendeu os meses de setembro e outubro de 2000 , o vento vinha das direções noroeste e leste, respectivamente. Nestes meses, os ventos podem ter apresentado contribuição para a dispersão dos odores na direção dos bairros considerados, agravando ainda mais o problema e a insatisfação popular.

Todavia, têm-se um alto percentual de moradores queixando-se da presença dos odores 0 ano todo ( $40 \%$ dos entrevistados); como foi analisado quando da identificação dos odores ao longo do ano.

Desta forma, comprova-se mais uma vez a relevância deste impacto, - qual caracteriza-se também como um impacto de vizinhança, na medida em que afeta a vida da população residente nas proximidades da ETE, comprometendo sua qualidade de vida. 


\section{Conclusões e Recomendações}

\subsection{Considerações Gerais}

A análise do impacto da proliferação de odores ofensivos do tratamento de esgotos, bem como de suas implicações na saúde e no bem estar das populações vizinhas, é de fundamental importância como medida de controle deste importante impacto de vizinhança, como prevenção do risco à Saúde Pública e ainda como ação de combate à indisposição que $o$ mesmo pode vir a ocasionar contra as estações de tratamento de esgotos.

Os odores podem diminuir o apetite, prejudicar a respiração, causar náuseas e vômitos e criar perturbações de humor. Em situações extremas podem conduzir ao deterioramento da dignidade pessoal e comunitária (restrições na utilização de áreas externas à residência ou escolas, fechamento de portas e janelas, para citar alguns exemplos); interferir nas. relações humanas (constrangimento diante de visitas); inibir investimentos e deter o crescimento de uma comunidade.

Apesar de todos os distúrbios de ordem física acarretados pelos odores, sua importância em termos humanos, está mais relacionada com a tensão psicológica que os mesmos originam, do que com o dano que podem vir a produzir no organismo (METCALF \& EDDY, 1985).

Entretanto, a Organização Mundial de Saúde (OMS) é a primeira a definir saúde não apenas como a ausência de doença, mas como a completo bem estar físico e social, o que inclui aí não exclusivamente a integridade física, como também a qualidade de vida.

No caso da população estudada, houveram relatos em que 0 desconforto ocasionado pelos odores era de tal forma acentuado, que as 
pessoas desejavam vender seus imóveis e procurar um lugar melhor para viver, longe do foco do problema, ou seja, longe da estação.

Sendo assim, a proliferação de odores ofensivos não corresponde apenas a um problema da população atingida, mas também da empresa responsável pela ETE. Nem a um, nem a outro, interessa que a situação se perpetue, sem que sejam tomadas providências para revertê-la. Muito pelo contrário, atualmente com o proclamado conceito do usuário-cliente, objetiva-se sempre 0 relacionamento saudávet e o pronto-atendimento às queixas e reclamações.

Desta forma, torna-se necessária a integração entre o órgão de saneamento responsável e a população local, em um esforço conjunto e contínuo na busca por soluções que controlem, ou ao menos, minimizem o. problema dos odores relacionados às ETEs.

\subsection{Considerações Acerca do Estudo Empreendida}

No trabalho apresentado, optou-se por uma abordagem do problema sob o ponto de vista da população atingida, sua percepção acerca do órgão responsável pela ETE, da importância do tratamento dos esgotos, da identificação do impacto, de aspectos relativos à sua presença e frequência, de fatores agravantes e de seus efeitos e implicações cotidianas.

Ao final deste estudo, considera-se alcançado o objetivo inicial que consistia na avaliação do impacto da proliferação de odores ofensivos. decorrentes da operação da ETE - Piracicamirim, em Piracicaba - SP, através da análise da percepção da população vizinha à estação.

O objetivo pôde ser atingido, uma vez que os dados coletados permitiram a identificação de variáveis e indicadores utilizados na análise que refletiu as opiniões dos entrevistados acerca do impacto a que estão 
sujeitos, além de proporcionar o cruzamento de informações pelo sistema "variável versus indicador", conforme apresentado no capítulo 8 ; e, de onde. se pôde acompanhar o comportamento do nivel de escolaridade em relação ao reconhecimento dos efeitos à exposição aos odores, por exemplo.

Considera-se também, que o instrumento de pesquisa empregado em campo (questionário), cumpriu com os propósitos para os quais foi desenvolvido, apesar de poder sofrer modificações que o tornem ainda mais eficiente na coleta de dados.

Quanto à hipótese levantada de que a proliferação de odores ofensivos decorrente da operação da ETE - Piracicamirim, em Piracicaba SP, repercutia negativamente sobre a saúde e o bem estar da população vizinha, compreendida pelo raio de $1 \mathrm{Km}$ ao redor da estação, a mesma fica comprovada pelos seguintes percentuais: identificação do impacto $(94 \%)$; necessidade de fechamento de portas e janelas (51\%); restrições no uso de áreas externas às residências $(41 \%)$; mau estar $(23 \%)$; doenças respiratórias (15\%).

Tem-se que 0 impacto da proliferação de odores caracterizou-se como uma questão de Saúde Pública, na medida em que influi principalmente no bem estar e, em menor proporção, por acarretar distúrbios físicos à população exposta ao problema.

\subsection{Observações e Recomendações Finais}

Quanto ao caso particular da ETE - Piracicamirim, a repercussão deste impacto foi tão expressiva, que o SEMAE está tomando providências no sentido de combater os odores, utilizando a aplicação no solo do gás sulfidrico. Este método consiste em coletar 0 gás por intermédio de 
exaustores colocados estrategicamente nas tubulações de saida dos reatores anaeróbios, sendo o gás então destinado para baixo do solo, num terreno com profundidade de $1 \mathrm{~m}$, coberto com escória de ferro, causando a reação química entre o ferro e o gás sulfidrico (SEMAE, 2002).

Também vem sendo motivada a criação de um conselho consultivo de moradores, cuja principal função é a de alertar o SEMAE, quando da ocorrência do problema e sua intensidade, promovendo assim a desejada interação empresa-usuário.

Estas providências remetem novamente à necessidade de uma correta avaliação da repercussão da implantação e operação das obras de saneamento, e, dentre elas, das estações de tratamento de esgotos sanitários.

Uma vez que o questionário utilizado em campo, mostrou-se eficiente para a coleta de dados e informações que permitiram a análise da percepção popular frente aos odores da ETE - Piracicamirim, conclui-se que o mesmo pode vir a ser aprimorado e aplicado a novos estudos de caso.

Neste sentido, recomenda-se estudos posteriores e complementares a este, não só contemplando o aspecto da análise do impacto através da percepção popular, como outros que não foram objeto deste estudo, mas que poderiam trazer subsídios à compreensão e reversão do problema dos odores atribuidos à ETEs, tais como: estudo de novas técnicas de combate à produção de odores ofensivos; tratamento de gases odorificos produzidos na estação; mensuração de odores na ETE e adjacências (até mesmo com a utilização de painéis de odor, se existirem condições em que sua aplicação se torne viável econômica e analiticamente), dentre outros.

Outro importante aspecto que necessita ser enfocado em relação à análise da proliferação de odores de ETEs, diz respeito ao tempo de exposição das pessoas ao impacto e suas consequências: imediatas, a médio prazo e a longo prazo. 
Finalizando, destaca-se novamente a importância e a necessidade de um planejamento adequado da estação de tratamento de esgotos ${ }_{1}$ desde a decisão pela melhor alternativa de tratamento para as condições disponiveis (após uma análise exaustiva das opções existentes), até a correta escotha do local onde a ETE irá ser implantada (de preferência, sem interferir negativamente no cotidiano das populações mais próximas à área).

Afinal, a estação de tratamento de esgotos deve ser concebida como uma obra pública de caráter social e sanitário, e sua inserção no contexto urbano deve servir às crescentes e urgentes necessidades das populações das cidades, visando garantir-thes a preservação dos recursos hídricos (cada dia mais escassos em quantidade e qualidade), a melhoria da qualidade de vida e da Saúde Pública. 


\section{Referências Bibliográficas}

ABES (1994). "Editorial - Uma Divida Social" In: Jornal ABES Associação Brasileira de Engenharia Sanitária e Ambiental - Seção Minas Gerais, Ano V, $n^{\circ} 13$. Belo Horizonte, p. 2.

ABES (1995). "Técnica e Política" In: Revista Bio, Ano VII, $n^{\circ} 3$, OUT I DEZ 1995. Associação Brasileira de Engenharia Sanitária e Ambiental. Rio de Janeiro, p. 31-34.

ALÉM SOBRINHO, P. (2000). "Tratamento de Esgoto e Geração de Lodo". In: "Impacto Ambiental do Uso Agricola do Lodo de Esgoto". Editores: Wagner Betiol e Otávio A. Camargo. EMBRAPA Meio Ambiente. Jaguariúna, p. 11-24.

ALÉM SOBRINHO, P. \& TSUTIYA, M. "Coleta e Transporte de Esgoto Sanitário" apud BELLI FILHO et alli, 2001a.

ANDRADE, T., et alli. "Uso Simultâneo de um Biofiltro Aerado Submerso para Tratamento Secundário de Esgoto Sanitário e para Biodesodorização de Ar Atmosférico Contendo Gás Sulfidrico $\left(\mathrm{H}_{2} \mathrm{~S}\right)$ " In: Pós-Tratamento de Efluentes de Reatores Anaeróbios Coletânea de Trabalhos Técnicos - Volume 2. Programa de Pesquisas em Saneamento Básico (PROSAB). Belo Horizonte, p. 141-152.

AZEVEDO NETTO, J.M. \& BOTELHO, M.H.C. (1991). "Manual de Saneamento de Cidades e Edificações". Editora Pini. São Paulo, $229 p$.

BARROS, F.G. \& CAMPOS, J.R. (1992). "Tratamento de Esgotos por Reator Anaeróbio Compartimentado" In: Anais do XXII Congresso Interamericano de Ingenieria Sanitaria Y Ambiental. Havana, Cuba. 
BARROS, R. T. V. et alli. (1995). "Manual de Saneamento e Proteção Ambiental para os Municipios". Universidade Federal de Minas Gerais. Belo Horizonte: Escola de Engenharia da UFMG, 221 p.

BATTALHA, B.L. \& PARLATORE, A.C. (1993). "Controle da Qualidade da Água para Consumo Humano - Bases Conceituais e Operacionais". Companhia de Tecnologia de Saneamento Ambiental (CETESB). São Paulo, $198 \mathrm{p}$

BELLI FILHO, P. \& DE MELO LISBOA, H. (1998). "Avaliaçăo de Emissões Odorantes" In: Revista de Engenharia Sanitária e Ambiental, vol $3, n^{\circ}$. 3, JUL/SET 1998. Associação Brasileira de Engenharia Sanitária e Ambiental (ABES). Rio de Janeiro, p. 101-106.

BELLI FILHO, P. et alli. (2000). "Controle de Odores e Biodesodorização em um Reator Anaeróbio" In: Pós-Tratamento de Efluentes de Reatores Anaeróbios - Coletânea de Trabalhos Técnicos - Volume 1. Programa de Pesquisas em Saneamento Básico (PROSAB). Belo Horizonte.

BELLI FILHO, P. et alli. (2001a). "Controle e Tratamento de Odores de um Reator Anaeróbio com Biofiltração" In: Pós-Tratamento de Efluentes de Reatores Anaeróbios - Coletânea de Trabalhos Técnicos - Volume 2. Programa de Pesquisas em Saneamento Básico (PROSAB). Belo Horizonte, p. 241-252.

BELLI FILHO, P. et alli. (2001b). "Tratamento de Odores em Sistemas de Esgotos Sanitários" In: Pós-Tratamento de Efluentes de Reatores Anaeróbios - Programa de Pesquisas em Saneamento Básico (PROSAB). Belo Horizonte, p. 455-490.

BISSET, R. (1980). "Métodos para Avaliação de Impacto Ambiental: Uma Mostra Seletiva com Estudos de Caso". Department of Geography, University of Aberdeen. Aberdeen, Escócia, $67 \mathrm{p}$. 
BOLEA, M.T.E. (1984). "Evalucion del Impacto Ambiental". Madri, Espanha, $609 \mathrm{p}$.

BRAILE, P.M. \& CAVALCANTI, J.E.W.A. (1993). “Manual de Tratamento de Águas Residuárias Industriais". Companhia de Tecnologia de Saneamento Ambiental (CETESB). São Paulo.

BRAUER, H. (1986). "Biological Purification of Waste Gases". International Chemical Engineering, 26 (6), p. 387-395.

BUNICORE, A.J. \& DAVES, W.T. (1992). "Air Pollution Engineering Mannual". Air and Waste Management Association (AWMA). Pittsburgh (EUA), p. 147-154.

CAMPOS, J.R. (1992). "Um Estudo sobre Reatores Anaeróbios de Leito Expandido". II Taller Regional sobre Tratamiento de Aguas Residuales en America Latina. Ciudad de La Habana, Cuba, 20 al 22 de Noviembre.

CAMPOS, J.R. (1994). "Alternativas para Tratamento de Esgotos - Pré Tratamento de Águas para Abastecimento". Consórcio Intermunicipal das Bacias dos Rios Piracicaba e Capivari. Publicação no. 9. Americana, $112 \mathrm{p}$.

CAMPOS, J.R. et alli (1999). "Tratamento de Esgotos Sanitários por Processo Anaeróbio e Disposição Controlada no Solo". Associação Brasileira de Engenharia Sanitária e Ambiental (ABES). Rio de Janeiro, $464 \mathrm{p}$.

CANELAS, L. et alli (1998). "Efeito dos Poluentes Atmosféricos na Saúde". Trabalho apresentado na cadeira de Poluição do Ar. Universidade de Lisboa, Portugal. Disponivel em: http://mirrors.fct.unl.pt/users/eipdf/par/par.htm. Acesso em 15 de maio de 2002. 
CBH-PCJ (1996). “Implantação, Resultados e Perspectivas". Comitê das

Bacias Hidrográficas dos Rios Piracicaba, Capivari e Jundiaí . Campinas, $76 p$.

CETESB (1975). "Lagoas de Estabilização". 2a . Edição. Companhia de Tecnologia de Saneamento Ambiental (CETESB). São Paulo, 241 p.

CHERNICHARO, C.A.L. (1997). "Reatores Anaeróbios". Departamento de Engenharia Sanitária e Ambiental (DESA). Universidade Federal de Minas Gerais (UFMG). Belo Horizonte, 245 p.

CIT (2002). "Relato de Intoxicação de Três Trabalhadores com Gás Sulfídrico em Curtume". Centro de Informação Toxicológica do Rio Grande do Sul (CIT). Disponivel em http://mww.cit.rs.gov.br/curare.htm. Acesso em 19 de maio de 2002.

CRANE, C.M. \& LANNAN, M.T. (1997). "An Odor Sampling Program by Neighborhood Residents". For Presentation at the Air \& Waste Management Association's $90^{\text {th }}$ Annual Meeting \& Exhibition - Toronto, Ontario, Canada.

DE SOUZA, R.C. (1998). "Avaliação dos Impactos Sociais dos. Processos de Implantação e Gestão dos Serviços de Tratamento de Esgotos Sanitários". Dissertação de Mestrado. Departamento de Engenharia Civil (DECiv). Universidade Federal de São Carlos (UFSCar). São Carlos, 203 p.

DE SOUZA, R.C. \& SALVADOR, N.N.B. (1997). "Proposta para Avaliaçăo dos Impactos Sociais nos Processos de Implantação e Operação dos Serviços de Tratamento de Esgotos Sanitários". In: Revista Engenharia Sanitária e Ambiental, vol. 2, $n^{\circ}$. 3, JULSET 1997. ABES: Rio de Janeiro, p. 91-95.

DIAS, S.P. et alli (2002). "Estudos de Simulação do Comportamento Sanitário e Controlo de Septicidade do Sistema Multimunicipal de 
Saneamento da Ria de Aveiro". Disponivel em: http://unw.apesb.pt/Comunicacoes/Com-59.htm. Acesso em 15 de maio de 2002.

ECOA (2002). "Ecologia em Notícias". Ediçăo 253 - 01/02/2001.

Disponivel em: http://unww.riosvivos.org.br/bolecoa253.htm. Ecologia em Ação (ECOA). Acesso em 19 maio 2002.

ELIAS, J.P. \& VASQUES, C.M.B. (1971). "Comunicação Humana em Saneamento Básico". In: VI Congresso Brasileiro de Engenharia Sanitária. São Paulo, p. 261-275.

EPA (1985). "Odor and Corrosion Control in Sanitary Sewerage Systems and Treatment Plants: Process Design Manual “. Environmental Protection Agency (EPA). Washington, D.C., USA.

FORESTI, E.; CAMPOS, J.R. \& RODRIGUES, B.A.S. (1980). "Notas de Aula sobre Sistemas de Esgotos Sanitários". Departamento de Hidráulica e Sanemento (SHS). Escola de Engenharia de São Carlos (EESC). Universidade de São Paulo (USP). São Carlos, 81 p.

FNS (1999). "Manual de Saneamento". $3^{\mathrm{a}}$. Edição. Fundação Nacional de Saúde (FNS). Ministério da Saúde. Brasília, 374 p.

FSESP (1981). "Manual de Saneamento”. 2a . Edição. Fundação Serviços de Saúde Pública (FSESP). Ministério da Saúde. Rio de Janeiro, 250 p.

HOLLANDA, E. (1996). "A Farra do Peixe: Moldura do Poder, o Lago Paranoá Também Sustenta Pescadores". In: Revista ISTO É, $n^{\circ}$. 1383, de 03/04/96. São Paulo.

JOHNSTONE, D.W.M. (1996). "Relationships Between the Water and Sanitation Sector and the Community; a Discussion Document". In: Anais do Seminário Internacional de Tratamento e Disposição de Esgotos Sanitários: tecnologia e perspectivas para o futuro. Companhia de Água e Esgotos de Brasília (CAESB). Brasilia, p. 114-127. 
JORDÃO, E.P. \& PESSÔA, C.A. (1995). "Tratamento de Esgotos Domésticos". $3^{a}$ Edição. Associação Brasileira de Engenharia Sanitária e Ambiental (ABES). Rio de Janeiro, 720 p.

KLAASSEN, C.D. (1996). "Casarett and Doull's Toxicology: The Basic Science of Poisons". International Edition. McGraw-Hill - Health Professions Division. USA, $1111 \mathrm{p}$.

LEOPOLD, L.B.; CLARKE, F.S.; HANSHAW, B.B. \& BASLEY, J.R. (1971). "A Procedure for Evalualing Environmental Impact". Washington, USA.

LESON, G. \& WINER, A.M. (1991). "Biofiltration: Innovative Air Pollution Control Technology for VOC Emissions". Air \& Waste Management Association, 41 (8), p. 1045-1054.

LETTINGA, G. et alli (1983). "High-Rate Anaerobic Waste-Water Treatment Using the UASB Reactor under a Wide Range of Temperature Conditions". Department of Water Pollution Control, Agricultural University - Wageningen, The Netherlands.

MAIA (1992). "Manual de Avaliação de Impacto Ambiental". SURHEMA GTZ: Convênio de Cooperação Técnica Brasil - Alemanha. Curitiba, Paraná (BR).

McGINLEY, D.L. \& McGINLEY, M.A. (1997). "Understanding Odor Panels and Odor Evaluations". For Presentation at the Air \& Waste Management Association's 90 $0^{\text {th }}$ Annual Meeting \& Exhibition. Toronto, Ontario, Canada, $8 \mathrm{p}$.

McMAHON, R. F. (1982). "Socieconomic Impacts of Water Quality. Strategies". EPA, USA.

METCALF \& EDDY. INC. (1985). "Ingenieria Sanitaria - Tratamiento, Evacuación y Reutilización de Aguas Residuales". Segunda Edición. Editorial Labor, S.A. Impresso en España. Barcelona, 969 p. 
MONTENEGRO, M.H.F.; PINTO, M.A.T. \& LUDUVICE, M.L. (1996). "Nova proposta de relacionamento entre o setor e a comunidade". In: Anais do Seminário Internacional de Tratamento e Disposição de Esgotos Sanitários: tecnologia e perspectivas para o futuro. Companhia de Água e Esgotos de Brasília (CAESB). Brasília, p. 7-12.

MONTICELI, J.J. \& MARTINS, J.P.S. (1993). "A Luta pela Água - nas Bacias dos Rios Piracicaba e Capivari". 1' edição. Editora EME. Capivari - SP.

MORITA, D.M. (1996). "Caracterização de Águas Residuárias - Sulfetos". Apostila do Curso: Técnicas Analíticas Aplicadas à Engenharia Sanitária e Ambiental. Departamento de Engenharia Hidráulica e Sanitária (PHD). Escola Politécnica da Universidade de São Paulo (EPUSP). São Paulo, $15 \mathrm{p}$.

NEGRI, B. (1992). "Urbanização e Demanda de Recursos Hidricos na Bacia do Rio Piracicaba no Estado de São Paulo". In: ATAS da Semana de Debates sobre Recursos Hídricos e Meio Ambiente - Etapa Piracicaba". 04 a 06 de maio de 1992. Consórcio Intermunicipal das Bacias dos Rios Piracicaba e Capivari. Departamento de Águas Energia Elétrica (DAEE). Fundação do Desenvolvimento Administrativo (FUNDAP). Piracicaba, p. 27-37.

NUCCI, N.L.R. (1978). "Tratamento de Esgotos Municipais por Disposiçăo no Solo e sua Aplicabilidade no Estado de São Paulo". Fundação Prefeito Faria Lima. São Paulo, 120 p.

PERRIN, M.L. (1994). “L'olfactométrie ou la mesure des odeurs". L'Environnement, 38, 4-5, 1994.

PIVELI, R.P. (1998). "Qualidade das Águas". Apostila do Curso: Qualidade Ambiental 1. Departamento de Saúde Ambiental (HSA) Faculdade de Saúde Pública (FSP). Universidade de São Paulo (USP). São Paulo, 217 p. 
PLUNKETT, E.R. (1987). "Handbook of Industrial Toxicology". Chemical Publishing Co., Inc. New York, N.Y., USA., 605 p.

PROCHNOW, M.C.R. (1981). "Qualidade das Águas na Bacia do Rio

Piracicaba". Dissertação de mestrado. Curso de Pós-Graduação em Geografia. Instituto de Geociências e Ciências Exatas. Universidade do Estado de São Paulo (UNESP). Rio Claro, 168 p.

RICHARDSON, J.R. et alli. (1985). "Pesquisa Social - Métodos a Técnicas". Editora Atlas. São Paulo, 389 p.

SABESP (1989). "Plano Diretor de Esgoto Sanitário da Regiãa Metropolitana de São Paulo". Companhia de Saneamento Básico do Estado de São Paulo (CETESB). São Paulo.

SALVADOR, N.N.B. (1989). "Avaliação de Impactos sobre a Qualidade dos Recursos Hidricos". Tese de doutoramento. Departamento de Hidráulica e Saneamento da Escola de Engenharia de São Carlos. Universidade de São Paulo. SHS - EESC - USP: São Carlos.

SEADE (1992). "Pobreza e Riqueza: Pesquisa de Condições de Vida na Região Metropolitana de São Paulo - Definição e Mensuração da Pobreza na Região Metropolitana de São Paulo: Uma Amostragem Multissetorial". Fundação Sistema Estadual de Análise de Dados. (SEADE). São Paulo, 154 p.

SEADE (2002). "População por Municipio no Estado de São Paulo". Fundação Sistema Estadual de Análise de Dados (SEADE). Disponivel em http://wnw. seade.gov.br. Acesso em 25 de agosto de 2002.

SEBASTIANES, J.A.M. (1992). "Histórico das Campanhas e Lutas pela Despoluição do Rio Piracicaba". In: "ATAS da Semana de Debates sobre Recursos Hidricos e Meio Ambiente - Etapa Piracicaba". 04 a 06 de maio de 1992. Consórcio Intermunicipal das Bacias dos Rios Piracicaba e Capivari. Departamento de Águas e Energia Elétrica 
(DAEE). Fundação do Desenvolvimento Administrativo (FUNDAP). Piracicaba, p. 1-9.

SEMAE (2002). "Serviço Municipal de Água e Esgoto de Piracicaba SP". Disponível em: http://uww. semaepiracicaba.org.br. Acesso em 22 de maio de 2002.

SIGRH (2002). "Sistema Integrado de Gerenciamento de Recursos Hídricos do Estado de São Paulo". Disponível em: http://www.sigrh.sp.gov.br. Acesso em 06 de setembro de 2002.

SILVA, A.S. \& MARA, D.D. (1979). "Tratamentos Bilógicos de Águas Residuárias". Associação Brasileira de Engenharia Sanitária e Ambiental (ABES). Rio de Janeiro, $140 \mathrm{p}$.

SMA (1994). "Estabelecimento de Metas Ambientais e Reenquadramento dos Corpos D'Água: Bacia do Rio Piracicaba". Secretaria do Meio Ambiente. Governo do Estado de São Paulo. São Paulo, 81p.

SPEECE, R.E. (1996). "Anaerobic Biotechnology for Industrial Wastewaters". Archae Press. Nashville, Tennesse, EUA, 394 p.

TOMMASI, L.R. (1993). "Estudo de Impacto Ambiental". Companhia de Tecnologia de Saneamento Ambiental (CETESB). São Paulo, 355 p.

UEHARA, M.Y. (1989). “Operação e Manutenção de Lagoas Anaeróbias e Facultativas". Companhia de Tecnologia de Saneamento Ambiental (CETESB). São Paulo, 91 p.

UNEP \& UNESCO (1975). "Environmental Impact Assessment:

Principles and Procedures". Scope Workshop on Impact Studies in the Environment (WISE). Toronto, Canada, $160 \mathrm{p}$.

USP-FSP (1998). "Guia de Apresentaçáo de Teses". Universidade de São Paulo. Faculdade de Saúde Pública. São Paulo, 62 p. 
VALÊNCIO, N.F.L.S. \& BORGES, J.R.P. (1997). "A Adequação do Conceito de Exclusão Social e Percepção Ambiental na Análise do Modo de Vida das Populações Litorâneas de Reservatórios com Estados Trópicos Diferenciados". Departamento de Ciências Sociais da Universidade Federal de São Carlos (UFSCar). São Carlos.

VAN HAANDEL, A.C. \& LETTINGA, G. (1994). "Tratamento Anaeróbio de Esgotos. Um Manual para Regiões de Clima Quente". Universidade Federal da Paraíba. Campina Grande, $232 \mathrm{p}$.

VON SPERLING, M. (1994). "Critérios e Dados para uma Seleção Preliminar de Sistemas de Tratamento de Esgotos". In: Engenharia Sanitária e Ambiental, Encarte da Revista Bio, Ano III, $n^{\circ}$ 1, JAN / ABR 1994. Associação Brasileira de Engenharia Sanitária e Ambiental (ABES). Rio de Janeiro, p. 7-21.

WHO (1994). "Financial Manager of Water Supply and Sanitation - a Handbook". World Health Organization (WHO). Geneva, 83 p. 


\section{ANEXO 1}

"Questionário para avaliação da repercussão de odores decorrentes de estações de tratamento de esgotos sobre as populações circunvizinhas - Percepção da população com relação ao impacto" 
UNIVERSIDADE DE SÃO PAULO

FACULDADE DE SAÚDE PÚBLICA

DEPARTAMENTO DE SAÚDE AMBIENTAL

Avaliação do Impacto da Proliferação de Odores Ofensivos do Tratamento de Esgotos

Sobre a Saúde e o Bem Estar Públicos

Questionário para avaliação da repercussão de odores decorrentes de estações de tratamento de esgotos sobre as populações circunvizinhas

"Percepção da população com relação ao impacto"

I. Identificação

1. Municipio: ( ) Piracicaba

( ) Cosmópolis

2. Data: I

Amostrador:

3. Nome do informante:

4. Sexo:

( ) Masculino

5. Idade:

( ) $10-15$

( ) $16-25$

( ) Feminino

( ) $46-55$

( ) $56-65$

( ) 26-35

( ) $36-45$

6. Endereço: Rua

( ) acima de 65 Bairro Distância aproximada da ETE $(\mathrm{m})$ :

7. Posição do entrevistado na estrutura familiar:
( ) pai
( ) mãe
( ) filho(a)
( ) genro
( ) nora
( ) neto(a)
( ) irmão(ã)
( ) sobrinho(a)
( ) primo(a)
( ) enteado(a)
( ) afilhado(a)
( ) outro:

II. Condições sócioeconômicas

8. Forma de apropriação do imóvel:
( ) casa própria:
( ) financiada
( ) quitada
( ) alugado
( ) emprestado
( ) invadido
( ) cedido
( ) outros:

9. Número de pessoas residentes no imóvel:

Renda familiar (em salários mínimos):
( ) até 1
( ) até 3
( ) até 5
( ) até 10
( ) acima de 10
( ) prefere não declarar
10. Escolaridade do entrevistado:
( ) analfabeto
( ) $1^{\circ}$ grau incompleto
( ) $1^{\circ}$ grau completo
( ) $2^{\circ}$ grau incompleto
( ) $2^{\circ}$ grau completo
( ) superior incompleto
( ) superior completo
( ) pós - graduação $n^{\circ}$ 


\section{Estrutura domiciliar e urbanidade}

11. Tempo de moradia no referido imóvel:

anos meses

12. Procedência da familia:

( ) zona urbana

( ) zona rural

13. Sempre morou em Piracicaba / Cosmópolis ?
( ) Sim
( ) Não
Veio de:

14. Motivo da vinda da família para a cidade de Piracicaba / Cosmópolis.
( ) trabalho
( ) escola
( ) razões familiares

( ) outros:

15. Indicação dos aspectos do local (bairro): $F=$ favorável $\quad D=$ desfavorável $\quad M=$ mais ou menos

( ) clima da região

( ) qualidade do ar

( ) proximidade do local de trabalho

( ) proximidade da escola, igreja, comércio

16. Qualidade dos serviços urbanos:

$$
\text { ( } N \text { = não existe; } \quad \mathrm{R}=\text { ruim; } \quad \mathrm{A}=\text { aceitável; } \quad \mathrm{B}=\text { bom) }
$$

( ) abastecimento de água

( ) serviço de coleta de lixo

( ) serviço de coleta de esgoto

( ) iluminação pública

( ) pavimentação

( ) transporte coletivo - ônibus urbanos

( ) limpeza pública

Obs:

17. Existência nas proximidades:

$N=$ não
( ) cemitério
( ) lixão
( ) aterro sanitário
( ) usina de açúcar
( ) usina de áicool
( ) indústrias:

१8. Informações sobre o imóvel domiciliar:

- número de cômodos:

- área construída aproximada $\left(\mathrm{m}^{2}\right)$ :

OBS:

19. Bens de consumo existentes no imóvel:
( ) automóvel
( ) motocicleta
( ) mobilete
( ) bicicleta
( ) fogão
( ) microondas
( ) geladeira
( ) freezer
( ) aspirador de pó
( ) lava-louças
( ) máq. de lavar
( ) tanquinho
( ) secadora
( ) máq.costura
( ) aparelho som
( ) rádio
( ) televisor
( ) video-cassete
( ) computador
( ) telefone
( ) fax
( ) ventilador
( ) circulador ar
( ) ar cond.
( ) outros:

20. Consumo de água potável:
( ) toma água direto da torneira
( ) filtra a água antes de beber

( ) busca água em mina

( ) ferve a água

( ) compra água mineral

( ) outros:

21. No imóvel existem:

( $S=\operatorname{sim} ; \quad N=$ não;

NS = não sabe)
( ) ligação domiciliar de água
( ) banheiro - quantidade:
( ) ligação domiciliar de esgoto
( ) fossa

Obs: 
IV. Avaliação em relação às questões ligadas às empresas de saneamento $\mathrm{e}$ ao tratamento de esgotos

22. Quem executa os serviços de água e esgoto na cidade é:
( ) O SEMAE
( ) o DAE
( ) a SABESP
( ) não sabe
( ) outros:

23. Classificação de serviços gerais prestados pela empresa de saneamento:
$(\mathrm{N}=$ nåo existe; $\quad \mathrm{R}=$ ruim; $\quad \mathrm{A}=$ aceitável;
$B=$ bom
$S=$ ainda năo precisou utilizar tal serviço)
( ) atendimento ao telefone
( ) reparos nas ligações domiciliares
( ) manutenção da rede de esgoto
( ) manutenção da rede de água
( ) conserto de hidrômetros
Causa:

24. As tarifas de água e esgoto da cidade são:
( ) muito caras
( ) caras
( ) razoáveis
( ) baixas
Preço méđio:

25. 0 esgoto deve ser:

( ) apenas lançado em fossas

( ) apenas lançado em rios ou outros corpos d'água

( ) deve ser tratado antes de sua disposição na terra ou no solo

( ) gutras:

26. Para onde está indo o esgoto produzido em sua residência:
( ) direto para o rio s/ tratamento
( ) para uma fossa
( ) para.a.ETE
( ) não sabe
( ) outras:

27. A operação da estação de tratamento de esgotos ocasionou ou está ocasionando a(s) seguinte(s) consequência(s):
( ) o aumento das tarifas
( ) a proliferação de insetos
( ) a melhoria da qualidade da água do rio
( ) um cheiro desagradávet
( ) a diminuição de doenças
( ) a produção de peixes
( ) melhoria do lazer na região
( ) nada
( ) não sabe de nenhuma estação
( ) outras:

28. A empresa responsável pela ETE tomou providências para controtar ou điminuir os distúrbios (efeitos negativos) sofridos pela vizinhança:
( ) Sim
( ) Não
( ) Não sei

Quais?

29. Como estava ocupada a área antes da implantação da ETE?
( ) não se lembra
( ) ainda não morava nas proximidades
( ) apenas um lote vago
( ) área verde
( ) entulho
( ) outras:

\section{QUESTÕES APLICÁVEIS APENAS EM CASO DE QUEIXA RELATJVA À ODORES}

V. Nivel de interferência dos odores de ETEs na vida pessoal e social da vizinhança 30. Os odores relacionados à ETE estão presentes:
( ) o ano todo
( ) apenas nos meses quentes
( ) ocasionalmente
( ) apenas nos meses frios 
31. Quando são sentidos os odores:

( ) durante todo o dia

( ) em períodos específicos do dia: ( ) manhã $\quad$ ( ) tarde $\quad$ ( ) noite

( ) em períodos diferenciados de acordo com as estações do ano

32. O problema dos maus odores da ETE:

( ) é agravado pela presença de outras fontes de poluição quais?

( ) não sofre interferência externa () não sabe afirmar com certeza

33. A presença dos maus odores da ETE ocasiona ou já ocasionou:

( ) restrições na utilização de jardins, quintais ou áreas externas da propriedade

( ) fechamento de janelas, portas ou elementos de ventilação da residência

( ) necessidade de aquisição de ventiladores, circuladores de ar ou ar condicionado

( ) doenças respiratórias ou alergias

( ) sensação de mau estar

( ) outros:

\section{Estrutura polilica-cultural}

34. Participação do entrevistado em associações comunitárias ou de bairro:

( ) não ( ) sim (especificar)

35. Caso resposta afirmativa no ítem 34 , quais os tipos de assunto tratados pela(s) instituição(ōes):
( ) moradia ( ) infraestrutura
( ) manifestação de rua
( ) política
( ) reliqião
( ) meio ambiente
( ) esportes
( ) artes
( ) outros:

36. Avaliação do entrevistado com relação aos resultados obtidos quando da apresentação de reivindicações públicas pelas instituições relacionadas no item 35 :

( ) as instituições não apresentam rejvindicações públicas

( ) os resultados não têm sido satisfatórios

( ) os resultados têm sido relativamente satisfatórios

( ) os resultados têm sido satisfatórios

37. Nivel de interesse em discussão política do entrevistado:

( ) o entrevistado não discute política

( ) o entrevistado discute política com:
( ) a família
( ) os vizinhos
( ) os amigos
( ) no trabalho

38. Classificação que o entrevistado confere a si próprio com relação à classe social a que pertence:
( ) rica ou abastada
( ) média alta
( ) média
( ) média baixa
( ) pobre
( ) outra:

Comentários adicionais: 
"Termo de Consentimento Livre e Esclarecido" 


\section{"AVALIAÇÃO DO IMPACTO DA PROLIFERAÇÃO DE ODORES OFENSIVOS DO TRATAMENTO DE ESGOTOS SOBRE A SAÚDE E O BEM ESTAR PÚBLICOS"}

\section{TERMO DE CONSENTIMENTO LIVRE E.ESCLARECIDO}

As estações de tratamento de esgotos - ETEs - são importantes para o combate à doenças de veiculação hídrica (transmitidas através da água contaminada) e ainda para o controle da poluição dos rios e córregos urbanos. Entretanto, estas mesmas estações também são responsáveis por uma série de incômodos que são sentidos principalmente pelas populações vizinhas. Dentre estas perturbações destacam-se os odores ofensivos "mau cheiro".

Este trabalho tem como objetivo estudar e avaliar o impacto dos maus odores sobre a saúde e o bem estar das populações que habitam áreas próximas às ETEs.

Dentre as etapas deste trabalho encontra-se a aplicação de um questionário que visa analisar a percepção do problema por parte das populações vizinhas às estações.

As entrevistas serão feitas em residências previamente sorteadas, onde um dos moradores será convidado a participar, tendo garantida a liberdade do indivíduo de aceitar ou não ser entrevistado e ainda que sua identidade será preservada quando da publicação dos resultados. Caso não seja obtido o consentimento na residência sorteada, a residência seguinte à direita será visitada e seus moradores receberão o convite para participar.

Como benefício direto à população, esta pesquisa pretende despertar a atenção do órgão de saneamento responsável (serviço de água e esgoto) para o problema dos maus odores e para a necessidade de uma solução eficaz.

Eu, abaixo assinado, concordo em participar desta entrevista, nos termos descritos por este documento.

de de 2000 . 
ANEXO 3

"Dados Primários" 
TOTALIZAÇÃO DOS RESULTADOS OBTIDOS PARA A ETE- PIRACICAMIRIM

ETAPA DE PESQUISA DE CAMPO / APLICAÇÃO DOS QUESTIONÁRIOS

\section{Identificação dos entrevistados}

Parâmetro analisado: Sexo dos entrevistados

\begin{tabular}{l|c|c|c|}
\hline \multicolumn{1}{|c|}{ Bairro } & Jardim Brasília & Vila Independência & Total de entrevistas \\
\hline Homens & 22 & 17 & 39 \\
\hline Mulheres & 27 & 20 & 47 \\
\hline Totat de entrevistados & 49 & 37 & 86 \\
\hline
\end{tabular}

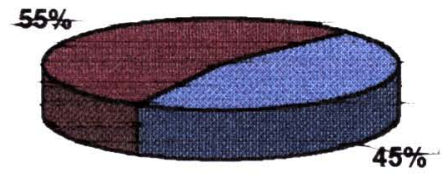

Parâmetro analisado: Idade dos entrevistados

\begin{tabular}{l|c|c|c|c|c|c|c|c|}
\hline Faixa etária (anos) & & & & & & acima & $\begin{array}{c}\text { Total de } \\
\text { entrevistas }\end{array}$ \\
\hline Jardim Brasília & 01 & 14 & 08 & 11 & 05 & 08 & 02 & 49 \\
\hline Vila Independência & 00 & 05 & 0.5 & 11 & 06 & 07 & 03 & 37 \\
\hline Totalização & 01 & 19 & 13 & 22 & 11 & 15 & 05 & 86 \\
\hline
\end{tabular}

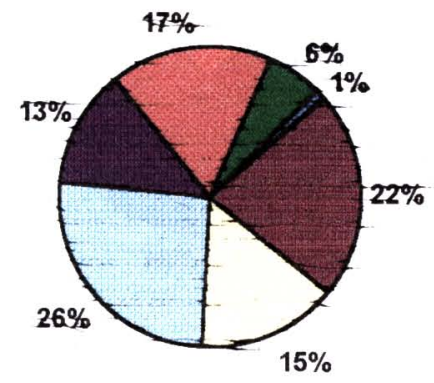

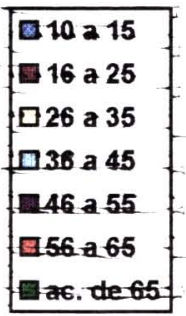

trac.te 65 . 
Parâmetro analisado: Posição do entrevistado na estrutura familiar

\begin{tabular}{|c|c|c|c|c|c|c|c|c|c|c|c|c|c|}
\hline $\begin{array}{l}\text { Posição do } \\
\text { entrevistado na } \\
\text { estrutura familiar }\end{array}$ & $\begin{array}{l}\text { P } \\
\text { A } \\
\text { I }\end{array}$ & $\begin{array}{l}\bar{M} \\
\tilde{A} \\
E\end{array}$ & $\begin{array}{c}F \\
1 \\
L \\
H \\
O \\
\text { (A) }\end{array}$ & $\begin{array}{l}G \\
E \\
N \\
R \\
O\end{array}$ & $\begin{array}{l}N \\
O \\
R \\
A\end{array}$ & $\begin{array}{l}N \\
E \\
T \\
O \\
\text { (A) }\end{array}$ & $\begin{array}{c}1 \\
R \\
\mathrm{R} \\
\tilde{A} \\
\tilde{A} \\
0 \\
\text { (A) }\end{array}$ & $\begin{array}{c}S \\
O \\
B \\
R \\
1 \\
1 \\
N \\
H \\
O \\
\text { (A) }\end{array}$ & $\begin{array}{c}P \\
R \\
1 \\
M \\
0 \\
\text { (A) }\end{array}$ & $\begin{array}{c}E \\
N \\
T \\
I \\
A \\
D \\
O \\
\text { (A) }\end{array}$ & $\begin{array}{c}A \\
A \\
F \\
I \\
L \\
H \\
A \\
D \\
O \\
\text { (A) }\end{array}$ & $\begin{array}{c}\sigma \\
U \\
T \\
R \\
0 \\
\text { (A) }\end{array}$ & $\begin{array}{l}\text { Total de } \\
\text { entrevistas }\end{array}$ \\
\hline Jardim Brasília & 16 & 20 & 11 & 01 & 01 & 00 & 00 & 00 & 00 & 00 & 00 & 00 & 49 \\
\hline Vita tndependência & $\uparrow 3$ & $\uparrow 6$ & 06 & 04 & 04 & 00 & 00 & 00 & 00 & 00 & 00 & 00 & 37 \\
\hline Totalização & 29 & 36 & 17 & 02 & 02 & 00 & 00 & 00 & 00 & 00 & 00 & 00 & 86 \\
\hline
\end{tabular}

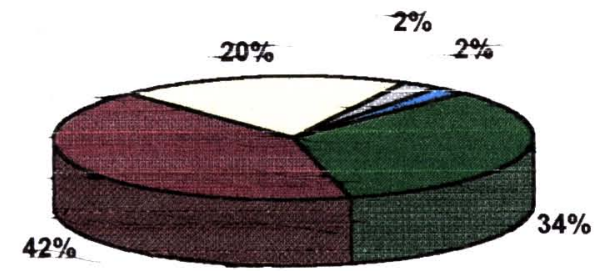

\begin{tabular}{|c|}
\hline Epai \\
\hline 匹 \\
\hline छfitho(e) \\
\hline Egenro \\
\hline Enora \\
\hline 区 neto(a) \\
\hline E irmão(ã) \\
\hline sobrinho(a) \\
\hline Eprimo(a) \\
\hline 口entiado(a) \\
\hline অafthadofat \\
\hline Eoutrolat \\
\hline
\end{tabular}

\section{Condições sócio-econômicas}

\section{Parâmetro analisado: Forma de apropriação do imóvel}

\begin{tabular}{|l|c|c|c|c|c|c|c|c|}
\hline $\begin{array}{c}\text { Forma de } \\
\text { apropriação }\end{array}$ & próprio & $\begin{array}{c}\text { finan- } \\
\text { ciado }\end{array}$ & $\begin{array}{c}\text { aluga- } \\
\text { do }\end{array}$ & $\begin{array}{c}\text { empres- } \\
\text { tado }\end{array}$ & $\begin{array}{c}\text { invadi- } \\
\text { do }\end{array}$ & cedido & outros & $\begin{array}{c}\text { Total de } \\
\text { entrevistas }\end{array}$ \\
\hline Jardim Brasilia & 39 & 00 & 10 & 00 & 00 & 00 & 00 & 49 \\
\hline Vila Independênciaz & 30 & 00 & 07 & 00 & 00 & 00 & 00 & 37 \\
\hline Totalização & 69 & 00 & 17 & 00 & 00 & 00 & 00 & 86 \\
\hline
\end{tabular}
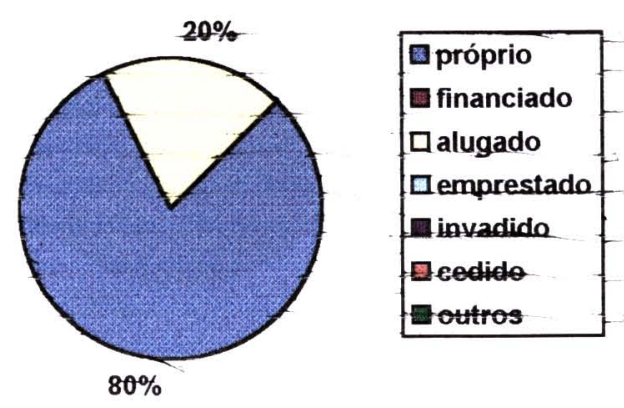


\section{Parâmetro analisado: Renda familiar}

\begin{tabular}{l|c|c|c|c|c|c|c|c|}
\hline $\begin{array}{c}\text { Renda Familiar } \\
\text { (em salários } \\
\text { mínimos) }\end{array}$ & $\begin{array}{c}\mathrm{n}^{\circ} . \text { médio } \\
\text { de } \\
\text { hab/casa }\end{array}$ & até 1 & até 3 & até 5 & até 10 & $\begin{array}{c}\text { acima } \\
\text { de 10 }\end{array}$ & $\begin{array}{c}\text { Prefere } \\
\text { não } \\
\text { declarar }\end{array}$ & $\begin{array}{c}\text { Total de } \\
\text { entrevistas }\end{array}$ \\
\hline Jardim Brasília & 3,85 & 00 & 04 & 06 & 17 & 13 & 09 & 49 \\
\hline Vila Independência & 3,91 & 00 & 02 & 06 & 14 & 12 & 03 & 37 \\
\hline Fotalização & 3,88 & 00 & 06 & 12 & 31 & 25 & 12 & 86 \\
\hline
\end{tabular}

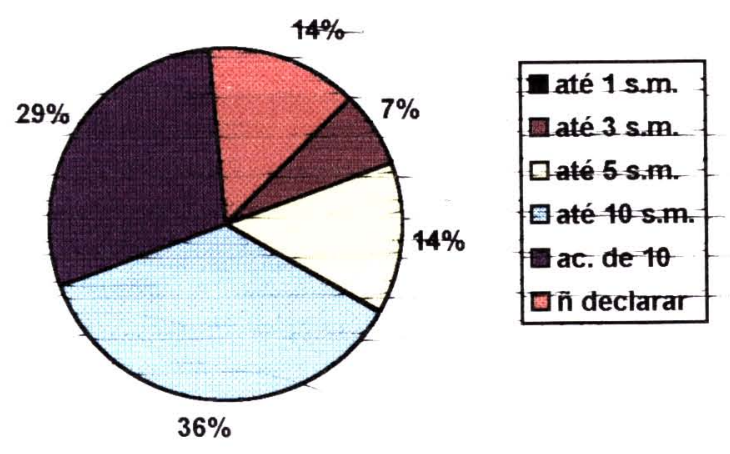

\section{Parâmetro analisado: Escolaridade do entrevistado}

\begin{tabular}{|l|c|c|c|c|c|c|c|c|c|}
\hline \multicolumn{1}{|c|}{ Escolaridade } & Analf. & $\begin{array}{c}1^{\circ} \text { grau } \\
\text { incomp. }\end{array}$ & $\begin{array}{c}1^{\circ} \text { grau } \\
\text { comp. }\end{array}$ & $\begin{array}{c}2 \text { grau } \\
\text { incomp. }\end{array}$ & $\begin{array}{c}2 \text { grau } \\
\text { comp. }\end{array}$ & $\begin{array}{c}\text { Superior } \\
\text { incomp. }\end{array}$ & $\begin{array}{c}\text { Superior } \\
\text { comp. }\end{array}$ & $\begin{array}{c}\text { Pós- } \\
\text { grad. }\end{array}$ & $\begin{array}{c}\text { Total de } \\
\text { entrevistas }\end{array}$ \\
\hline Jardim Brasítia & 00 & 10 & 11 & 11 & 12 & 01 & 04 & 00 & 49 \\
\hline Vila Independência & 00 & 20 & 02 & 05 & 03 & 02 & 01 & 04 & 37 \\
\hline Totalizaçăo & 00 & 30 & 13 & 16 & 15 & 03 & 05 & 04 & 86 \\
\hline
\end{tabular}
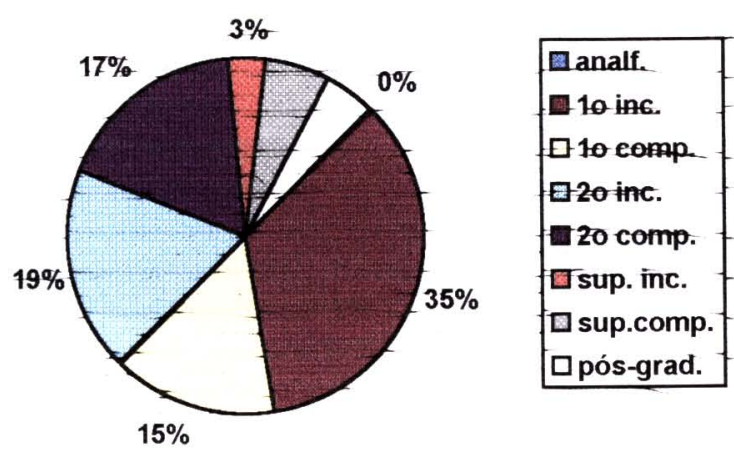
Parâmetro analisado: Tempo de moradia no imóvel; Procedência da familia (urbana ou rural)

\begin{tabular}{|l|c|c|c|c|}
\hline $\begin{array}{c}\text { Procedência da } \\
\text { família }\end{array}$ & Zona Urbana & $\begin{array}{c}\text { Zona } \\
\text { Rural }\end{array}$ & $\begin{array}{c}\text { Tempo de moradia no imóvel / } \\
\text { Média das familias (anos) }\end{array}$ & $\begin{array}{c}\text { Total de } \\
\text { entrevistas }\end{array}$ \\
\hline Jardim Brasília & 43 & 06 & 10,26 & 49 \\
\hline Vita Independência & 30 & 07 & 15,71 & 37 \\
\hline Totalização & 73 & 13 & 12,98 & 86 \\
\hline
\end{tabular}

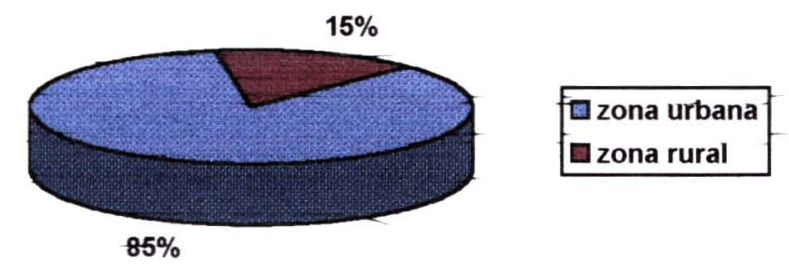

Parâmetro analisado: Procedência da famítia (Piracicaba ou outra tocatidade) e Motivo de vinda para o local (das familias de outras localidades que vieram para Piracicaba)

\begin{tabular}{|c|c|c|c|c|c|c|c|}
\hline \multirow[b]{2}{*}{ Bairro } & \multicolumn{2}{|c|}{ Procedência da família } & \multicolumn{4}{|c|}{ Motivo da vinda para o local } & \multirow{2}{*}{$\begin{array}{c}\text { Total } \\
\text { de } \\
\text { entrevistas }\end{array}$} \\
\hline & Piracicaba & $\begin{array}{c}\text { Outra } \\
\text { localidade }\end{array}$ & trabalho & escola & $\begin{array}{c}\text { razões } \\
\text { familiares }\end{array}$ & outros & \\
\hline Jardim Brasilia & 31 & 18 & 06 & 01 & 10 & $\theta 1$ & 49 \\
\hline Vila Independência & 26 & 11 & 04 & 02 & 05 & 00 & 37 \\
\hline Totalização & 57 & 29 & 10 & 03 & 15 & 01 & 86 \\
\hline
\end{tabular}

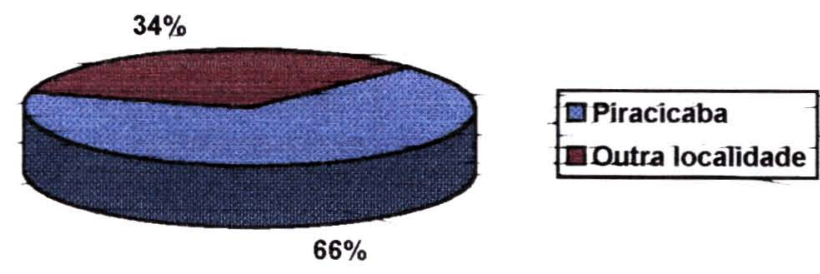


Para as famílias procedentes de outras localidades, os motivos de vinda para Piracicaba encontram-se itustrados no gráfico seguinte:

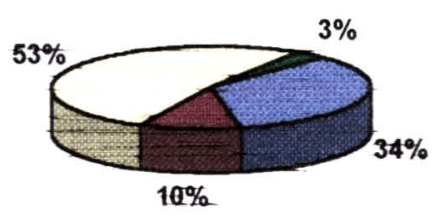

Trabalho
घescola
Grazões familiares
Eoutros

\section{Estrutura domiciliar e urbanidade}

\section{Parâmetro analisado: Indicação dos aspectos do local (bairros)}

\begin{tabular}{|c|c|c|c|c|c|c|c|c|c|c|c|c|}
\hline \multirow{3}{*}{ Bairro } & \multicolumn{12}{|c|}{$\begin{array}{l}\text { Indicação dos aspectos do local } \\
\text { favorável (f), desfavorável(d), mais ou menos }( \pm) \text { ou não respondeu }(\mathrm{nr})\end{array}$} \\
\hline & \multicolumn{3}{|c|}{ clima } & \multicolumn{3}{|c|}{ qualidade do ar } & \multicolumn{3}{|c|}{$\begin{array}{l}\text { proximidade do } \\
\text { local de trabalho }\end{array}$} & \multicolumn{3}{|c|}{$\begin{array}{l}\text { prox. de escola, } \\
\text { igreja, comércio }\end{array}$} \\
\hline & $f$ & d & \pm & $f$ & d & \pm & $f$ & d & \pm & $f$ & d & \pm \\
\hline Jardim Brasília & 35 & 03 & 11 & 10 & 21 & 18 & 33 & 09 & 07 & 30 & 08 & 11 \\
\hline Vila Independência & 24 & 05 & 08 & 19 & 10 & 08 & 22 & 08 & 07 & 25 & 06 & 06 \\
\hline Totalizaçãa & 59 & 08 & 19 & 29 & 31 & 26 & 55 & 17 & 14 & 55 & 14 & 17 \\
\hline
\end{tabular}
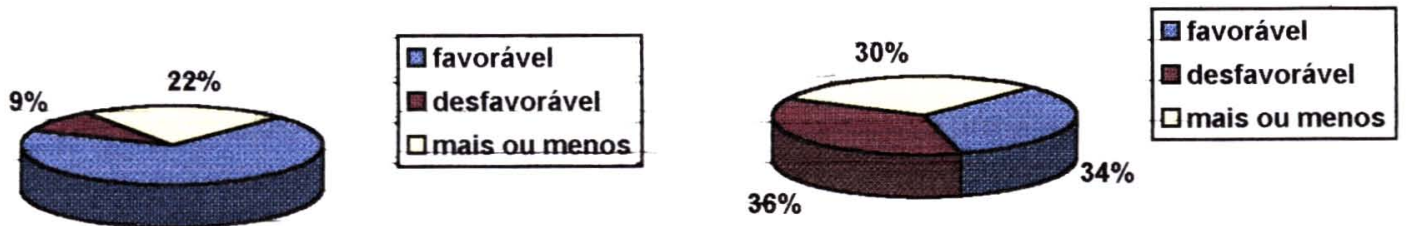
Prox. de escola, igreja, comércio

Prox. local de trabalho
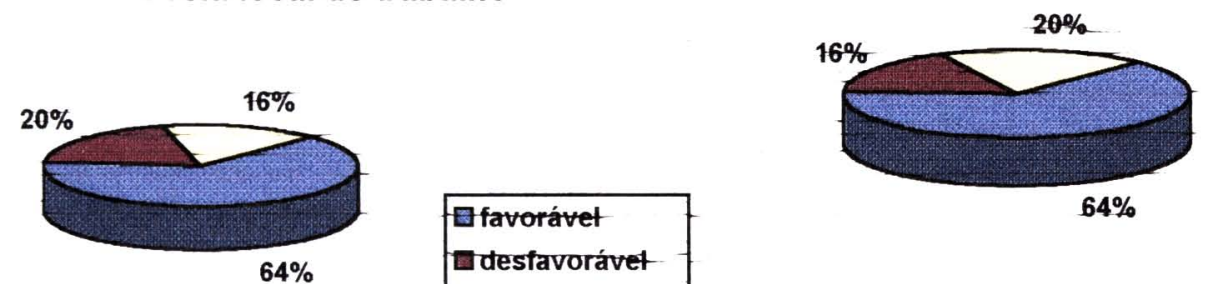

Gavorável

desfavorável

amais ou menos

Imais ou ménos

Parâmetro analisado: Qualidade dos serviços urbanos (bairros) - Planilha 1

\begin{tabular}{|c|c|c|c|c|c|c|c|c|c|c|c|c|c|c|c|c|}
\hline \multirow{3}{*}{ Bairro } & \multicolumn{16}{|c|}{$\begin{array}{l}\text { Qualidade dos serviços urbanos } \\
N=\text { não existe; } R=\text { ruim; } A=\text { aceitável; } B=\text { bom }\end{array}$} \\
\hline & \multicolumn{4}{|c|}{ abast. água } & \multicolumn{4}{|c|}{ coleta esgoto } & \multicolumn{4}{|c|}{ pavimen-tação } & \multicolumn{4}{|c|}{ limpeza pública } \\
\hline & $\mathrm{N}$ & $\mathrm{R}$ & $A$ & $\mathrm{~B}$ & $\mathrm{~N}$ & $\mathrm{R}$ & $A$ & $\mathrm{~B}$ & $\mathrm{~N}$ & $\bar{R}$ & $A$ & $\mathrm{~B}$ & $\mathrm{~N}$ & $\mathrm{R}$ & $A$ & $B$ \\
\hline Jardim Brasília & 00 & 01 & 02 & 46 & 00 & 00 & 04 & 45 & $\theta \theta$ & 24 & 10 & 15 & 00 & 14 & 09 & 26 \\
\hline Vila Independência & 00 & 00 & 03 & 34 & 00 & 01 & 01 & 35 & 00 & 16 & 08 & 13 & 04 & 14 & 10 & 09 \\
\hline Totalização & 00 & 01 & 05 & 80 & 00 & 01 & 05 & 80 & 00 & 40 & 18 & 28 & 04 & 28 & 19 & 35 \\
\hline
\end{tabular}

Abastecimento de água

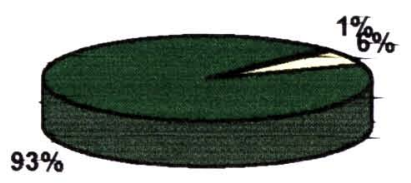

Coleta de esgoto

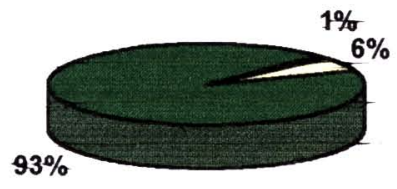

Tnão existe

ruim

口aceitável

abom

Pavimentação

Limpeza pública

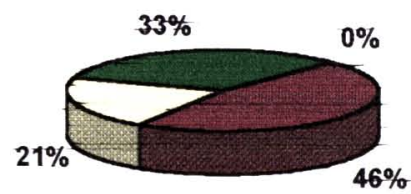

\begin{tabular}{|l|}
\hline não existe \\
\hline ruim \\
$\square$ aceitável \\
\hline bom \\
\hline
\end{tabular}

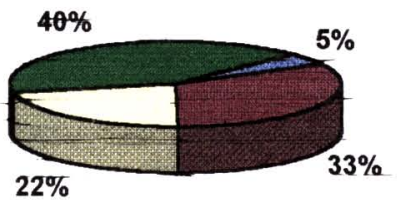

\begin{tabular}{|l|}
\hline$\square$ não existe \\
\hline G ruim \\
\hline$\square$ aceitável \\
\hline bom
\end{tabular} 
Parâmetro analisado: Qualidade dos serviços urbanos (bairros) - Planilha 2

\begin{tabular}{|c|c|c|c|c|c|c|c|c|c|c|c|c|}
\hline \multirow{3}{*}{ Bairro } & \multicolumn{12}{|c|}{$\begin{array}{c}\text { Qualidade dos serviços urbanos } \\
N=\text { não existe; } R=\text { ruim; } A=\text { aceitável; } B=\text { bom }\end{array}$} \\
\hline & \multicolumn{4}{|c|}{ coleta lixo } & \multicolumn{4}{|c|}{ iluminação pública } & \multicolumn{4}{|c|}{ transporte coletivo } \\
\hline & $\mathrm{N}$ & $R$ & $A$ & $\mathrm{~B}$ & $\mathrm{~N}$ & $R$ & $A$ & $B$ & $\mathrm{~N}$ & $\mathrm{R}$ & $A$ & $\mathrm{~B}$ \\
\hline Jardim Brasília & 00 & 00 & 02 & 47 & 00 & 10 & 07 & 32 & $\theta 0$ & 00 & $\theta 4$ & 45 \\
\hline Vila Independência & 00 & 01 & 03 & 33 & 00 & 06 & 08 & 23 & 00 & 01 & 04 & 32 \\
\hline Totalização & 00 & 01 & 05 & 80 & 00 & 16 & 15 & 55 & 00 & 01 & 08 & 77 \\
\hline
\end{tabular}

\section{Coleta de lixo}

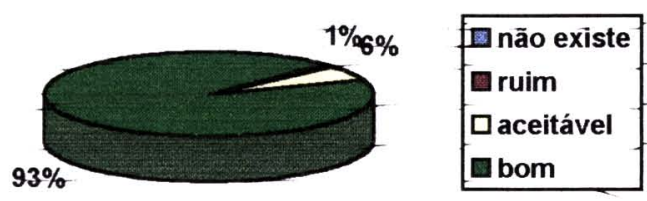

Iluminação pública

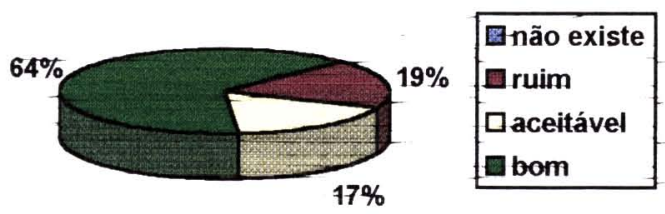

Transporte coletivo

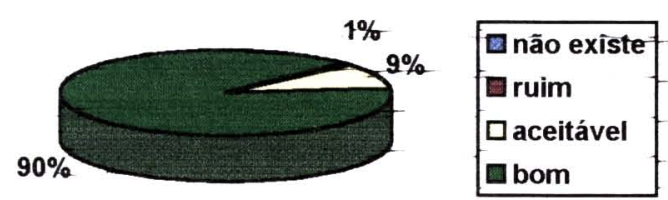


Parâmetro analisado: Percepção referente à fontes poluidoras próximas

\begin{tabular}{|c|c|c|c|c|c|c|c|c|c|c|c|c|c|c|}
\hline \multirow{3}{*}{ Bairra } & \multicolumn{14}{|c|}{ Existência nas proximidades $-\mathrm{S}=\operatorname{sim} ; \mathrm{N}=$ não } \\
\hline & \multicolumn{2}{|c|}{$\begin{array}{l}\text { cemité- } \\
\text { rio }\end{array}$} & \multicolumn{2}{|c|}{ lixão } & \multicolumn{2}{|c|}{$\begin{array}{c}\text { aterro } \\
\text { sanitário }\end{array}$} & \multicolumn{2}{|c|}{$\begin{array}{l}\text { usina de } \\
\text { açúcar }\end{array}$} & \multicolumn{2}{|c|}{$\begin{array}{l}\text { usina de } \\
\text { álcool }\end{array}$} & \multicolumn{2}{|c|}{$\begin{array}{l}\text { indús- } \\
\text { trias }\end{array}$} & \multicolumn{2}{|c|}{$\begin{array}{l}\text { outras } \\
\text { fontes }\end{array}$} \\
\hline & $\mathrm{S}$ & $\mathrm{N}$ & $\mathrm{s}$ & $\mathrm{N}$ & $S$ & $\mathrm{~N}$ & $\mathrm{~S}$ & $\mathrm{~N}$ & $\mathrm{~s}$ & $\mathrm{~N}$ & S & $N$ & $\mathrm{~S}$ & $\mathrm{~N}$ \\
\hline Jardim Brasília & 00 & 49 & 01 & 48 & 00 & 49 & 04 & 45 & 00 & 49 & 00 & 49 & 06 & 43 \\
\hline Vila Independência & 00 & 37 & 00 & 37 & $\theta \theta$ & 37 & 09 & 28 & $\theta \theta$ & 37 & 04 & 33 & 00 & 37 \\
\hline Totalização & 00 & 86 & 01 & 85 & 00 & 86 & 43 & 73 & 00 & 86 & 04 & 82 & 06 & 80 \\
\hline
\end{tabular}

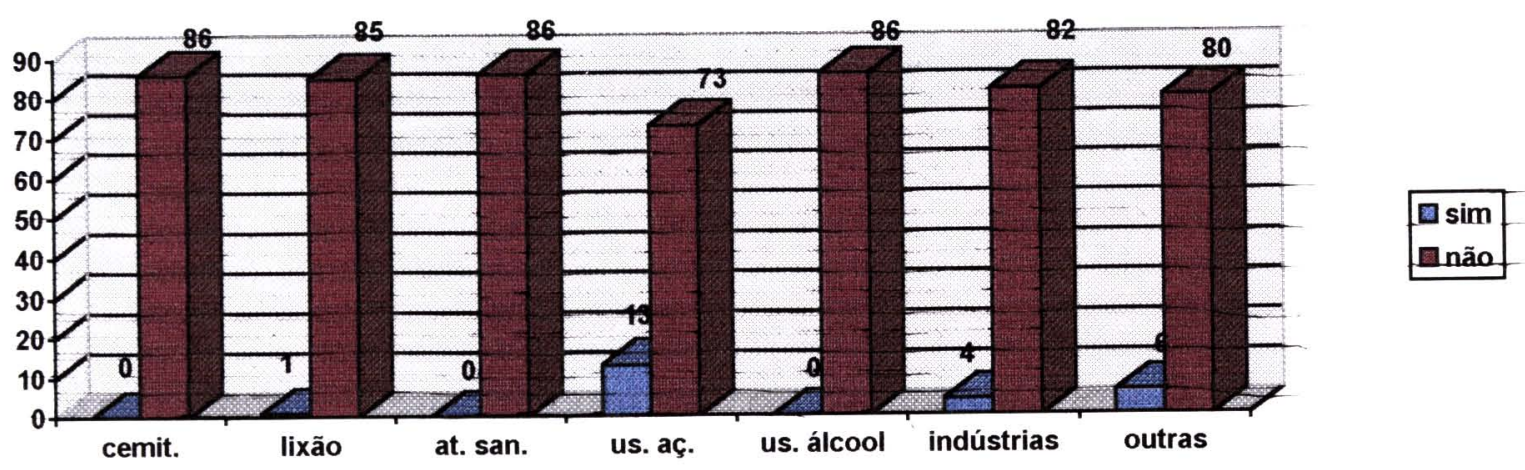

Parâmetro analisado: Informações sobre o imóvel domiciliar

\begin{tabular}{|l|c|}
\hline \multicolumn{1}{|c|}{ Bairro } & Média do ${ }^{\circ}$ de cômodos por residência \\
\hline Jardim Brasilia & 5,75 \\
\hline Vila Independência & 5,58 \\
\hline Totalização & 5,66 \\
\hline
\end{tabular}

Parâmetro analisado: Bens de consumo existentes no imóvel-Planilha 1

\begin{tabular}{|c|c|c|c|c|c|c|c|c|c|c|c|c|c|c|c|c|}
\hline \multirow{3}{*}{ Baifro } & \multicolumn{16}{|c|}{ Bens de consumo existentes no imóvel } \\
\hline & \multicolumn{2}{|c|}{ auto } & \multicolumn{2}{|c|}{ moto } & \multicolumn{2}{|c|}{ mobil. } & \multicolumn{2}{|c|}{ bicic. } & \multicolumn{2}{|c|}{ fogãa } & \multicolumn{2}{|c|}{ micr. } & \multicolumn{2}{|c|}{ gelad. } & \multicolumn{2}{|c|}{ freez. } \\
\hline & $\mathrm{s}$ & $\mathrm{N}$ & S & $\mathrm{N}$ & $\mathbf{s}$ & $\mathrm{N}$ & s & $\mathrm{N}$ & S & $\mathrm{N}$ & s & $N$ & $\mathrm{~S}$ & $\mathrm{~N}$ & s & $\mathrm{N}$ \\
\hline $\begin{array}{l}\text { Jardim } \\
\text { Brasília }\end{array}$ & 44 & 05 & 01 & 48 & 00 & 49 & 04 & 45 & 49 & 00 & 19 & 30 & 49 & 00 & 02 & 47 \\
\hline $\begin{array}{l}\text { Vita } \\
\text { Independ }\end{array}$ & 29 & 08 & 01 & 36 & $\theta \theta$ & 37 & 02 & 35 & 37 & $\theta 0$ & 13 & 24 & 37 & 00 & 02 & 35 \\
\hline Totaliz. & 73 & 13 & 02 & 84 & 00 & 86 & 06 & 80 & 86 & 00 & 32 & 54 & 86 & 00 & 04 & 82 \\
\hline
\end{tabular}




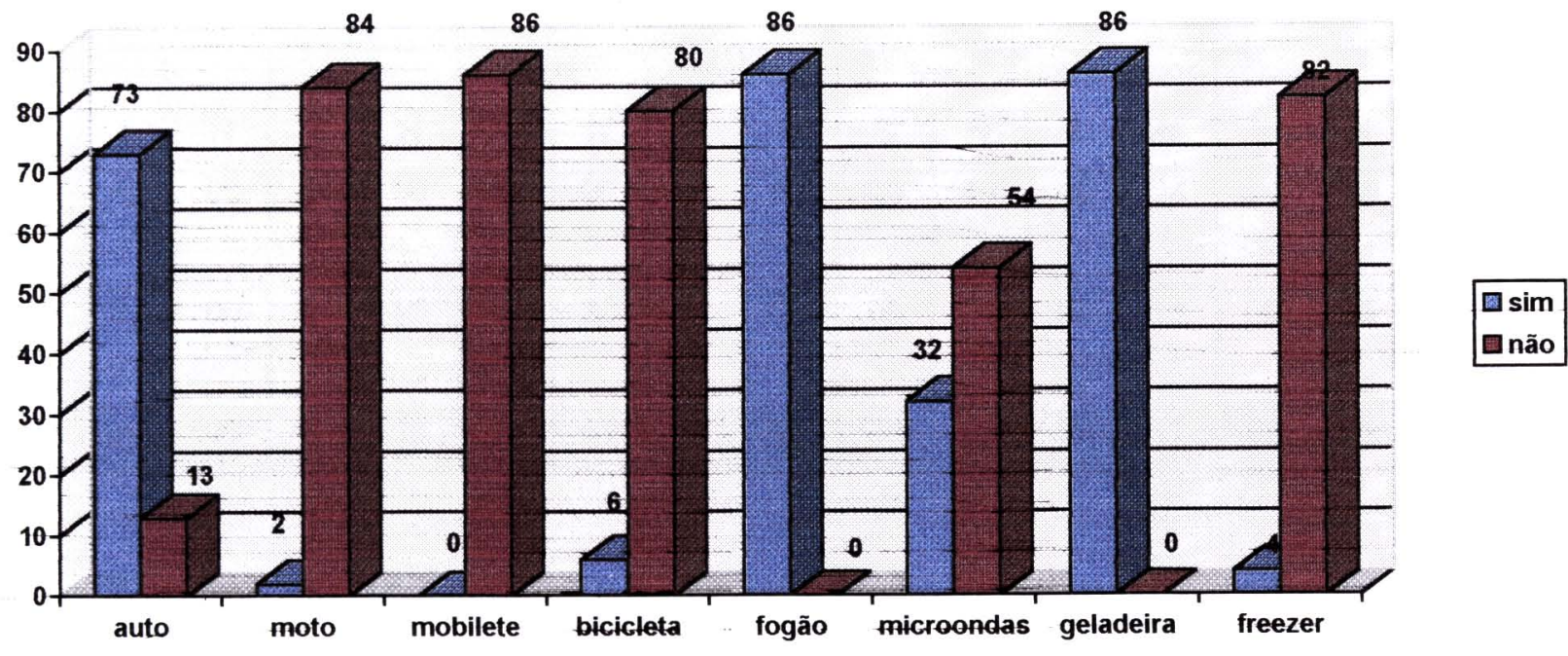

Parâmetro analisado: Bens de consumo existentes no imóvel-Planilha 2

\begin{tabular}{|c|c|c|c|c|c|c|c|c|c|c|c|c|c|c|c|c|}
\hline \multirow{3}{*}{ Baifro } & \multicolumn{16}{|c|}{ Bens de consumo existentes no imóvel } \\
\hline & \multicolumn{2}{|c|}{ asp. } & \multicolumn{2}{|c|}{ lav.t. } & \multicolumn{2}{|c|}{ m. lav } & \multicolumn{2}{|c|}{$\tan q}$. & \multicolumn{2}{|c|}{ secad } & \multicolumn{2}{|c|}{ mcost } & \multicolumn{2}{|c|}{ som } & \multicolumn{2}{|c|}{ rádio } \\
\hline & $\mathrm{s}$ & $\mathrm{N}$ & S & $\mathrm{N}$ & $\mathrm{s}$ & $\mathrm{N}$ & $\mathrm{s}$ & $\mathrm{N}$ & $\mathrm{s}$ & $\mathrm{N}$ & $\mathrm{s}$ & $\mathrm{N}$ & $\mathrm{S}$ & $\mathrm{N}$ & $S$ & $\mathrm{~N}$ \\
\hline $\begin{array}{l}\text { Jardim } \\
\text { Brasília }\end{array}$ & 05 & 44 & 04 & 45 & 39 & 10 & 07 & 42 & 00 & 49 & 10 & 39 & 46 & 03 & 48 & 01 \\
\hline $\begin{array}{l}\text { Vila } \\
\text { Independ }\end{array}$ & 00 & 37 & 02 & 35 & 11 & 26 & 24 & 13 & 00 & 37 & 00 & 37 & 28 & 09 & 29 & 08 \\
\hline Totaliz. & 05 & 81 & 06 & 80 & 50 & 36 & 31 & 55 & 00 & 86 & 10 & 76 & 74 & 12 & 77 & 09 \\
\hline
\end{tabular}

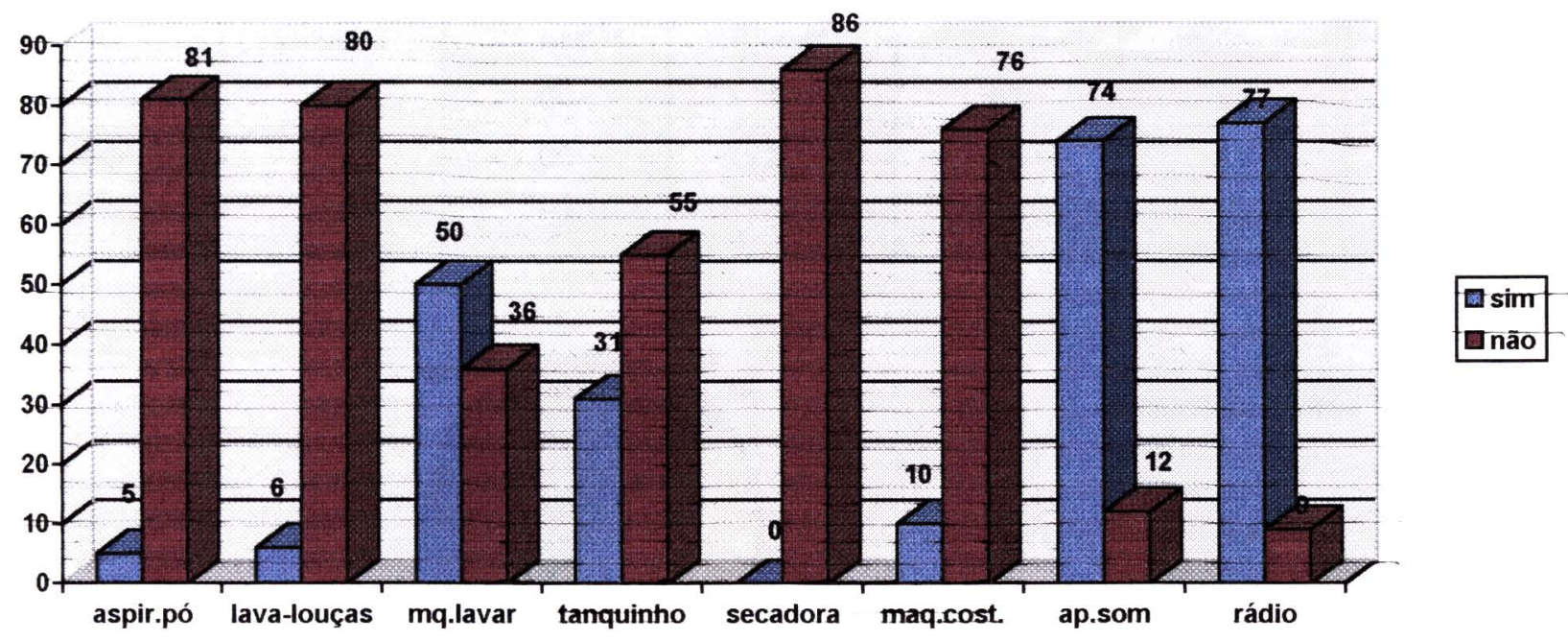


Parâmetro analisado: Bens de consumo existentes no imóvel - Planilha 3

\begin{tabular}{|c|c|c|c|c|c|c|c|c|c|c|c|c|c|c|c|c|}
\hline \multirow{3}{*}{ Bairro } & \multicolumn{16}{|c|}{ Bens de consumo existentes no imóvel } \\
\hline & \multicolumn{2}{|c|}{ tv } & \multicolumn{2}{|c|}{ video } & \multicolumn{2}{|c|}{ comp. } & \multicolumn{2}{|c|}{ telefone } & \multicolumn{2}{|c|}{ fax } & \multicolumn{2}{|c|}{ ventilador } & \multicolumn{2}{|c|}{ circ. ar } & \multicolumn{2}{|c|}{ ar cond. } \\
\hline & $\mathrm{S}$ & $\mathrm{N}$ & S & $\mathrm{N}$ & $\mathrm{S}$ & $\mathrm{N}$ & $\mathrm{S}$ & $\mathrm{N}$ & $\mathrm{s}$ & $\mathrm{N}$ & $\mathrm{s}$ & $\mathrm{N}$ & $\mathrm{s}$ & $\mathrm{N}$ & $\mathrm{s}$ & $\mathrm{N}$ \\
\hline $\begin{array}{l}\text { Jardim } \\
\text { Brasília }\end{array}$ & 49 & 00 & 41 & 08 & 12 & 37 & 48 & 01 & 00 & 49 & 45 & 04 & 04 & 45 & 01 & 48 \\
\hline $\begin{array}{l}\text { Vila } \\
\text { Independ }\end{array}$ & 37 & 00 & 31 & 06 & 07 & 30 & 31 & 06 & $\theta 0$ & 37 & 24 & 13 & 02 & 35 & 00 & 37 \\
\hline Totaliz. & 86 & 00 & 72 & 14 & 19 & 67 & 79 & 07 & $O C$ & 86 & 69 & 17 & 06 & 80 & 01 & 85 \\
\hline
\end{tabular}

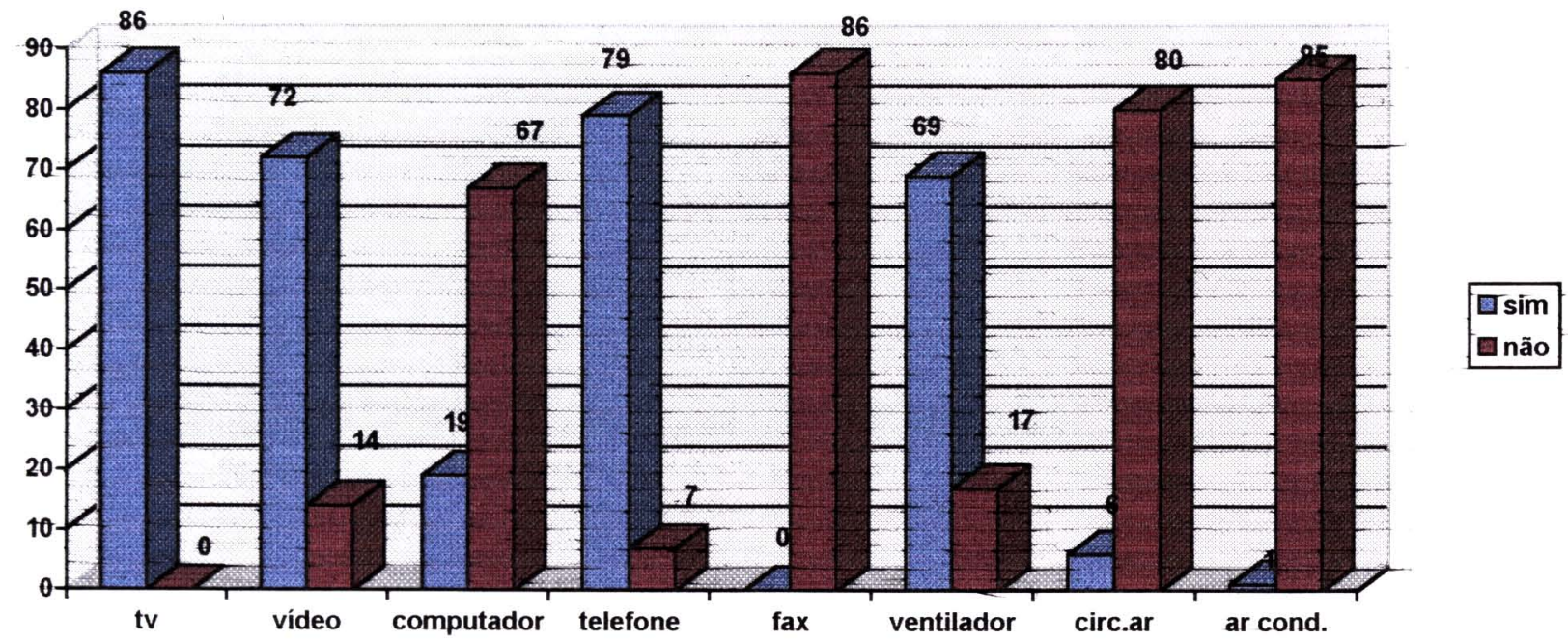

Parâmetro analisado: Constłmo de água potável

\begin{tabular}{|l|c|c|c|c|c|c|}
\hline \multirow{2}{*}{ Bairro } & \multicolumn{6}{|c|}{ Consumo de água potável } \\
\cline { 2 - 7 } & $\begin{array}{c}\text { Toma água } \\
\text { direto da } \\
\text { torneira }\end{array}$ & $\begin{array}{c}\text { Ferve a } \\
\text { água antes } \\
\text { de beber }\end{array}$ & $\begin{array}{c}\text { Filtra a água } \\
\text { antes de } \\
\text { beber }\end{array}$ & $\begin{array}{c}\text { Busca a } \\
\text { água na } \\
\text { mina }\end{array}$ & $\begin{array}{c}\text { Compra } \\
\text { água } \\
\text { mineral }\end{array}$ & Outro \\
\hline Jafdim Brasília & 00 & 00 & 17 & 07 & 25 & 00 \\
\hline Vila Independência & 01 & 00 & 22 & 00 & 11 & 03 \\
\hline Totalização & 01 & 00 & 39 & 07 & 36 & 03 \\
\hline
\end{tabular}

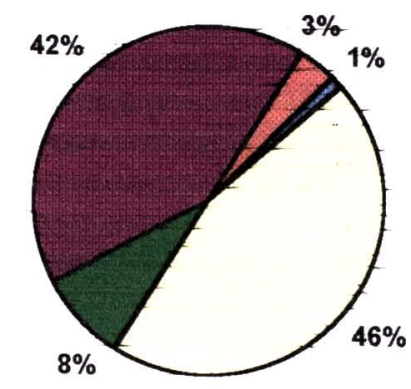

\begin{tabular}{|l|}
\hline díreto da tormeira \\
$\square$ ferve \\
$\square$ filtra \\
$\square$ busca na mina \\
$\square$ compra água min. \\
$\square$ outro
\end{tabular}


Parâmetro analisado: Instalações sanitárias

\begin{tabular}{|c|c|c|c|c|c|c|c|c|c|c|c|c|c|c|}
\hline \multirow{3}{*}{ Bairro } & \multirow{3}{*}{$\begin{array}{c}\mathrm{n}^{\circ} \\
\text { médio } \\
\text { de } \\
\text { hab/casa }\end{array}$} & \multicolumn{13}{|c|}{ Instalaçöes sanitárias ( $S=\operatorname{sim} ; N=$ não; $N S=$ não sabe) - indicar a quantidade } \\
\hline & & \multicolumn{3}{|c|}{$\begin{array}{l}\text { lig. domiciliar } \\
\text { de água }\end{array}$} & \multicolumn{3}{|c|}{$\begin{array}{l}\text { lig. domiciliar } \\
\text { de esgoto }\end{array}$} & \multicolumn{3}{|c|}{ banheiro } & \multicolumn{3}{|c|}{ fossa } & \multirow{2}{*}{$\begin{array}{c}\text { média geral } \\
\text { de } \\
\text { banh/casa }\end{array}$} \\
\hline & & $\mathrm{S}$ & $\mathrm{N}$ & NS & $\mathrm{S}$ & $\mathrm{N}$ & NS & $\mathrm{S}$ & $\mathrm{N}$ & NS & $\mathrm{S}$ & $\mathrm{N}$ & NS & \\
\hline $\begin{array}{l}\text { Jardim } \\
\text { Brasilia }\end{array}$ & 3,85 & 49 & 00 & 00 & 49 & 00 & 00 & 49 & 00 & 00 & 00 & 49 & 00 & 1,77 \\
\hline $\begin{array}{l}\text { Vila } \\
\text { Independência }\end{array}$ & 3,91 & 37 & 00 & 00 & 37 & 00 & Do & 37 & 00 & 00 & 00 & 37 & 00 & 1,73 \\
\hline Totalização & 3,88 & 86 & 00 & 00 & 86 & 00 & 00 & 86 & 00 & 00 & 00 & 86 & 00 & 1,75 \\
\hline
\end{tabular}

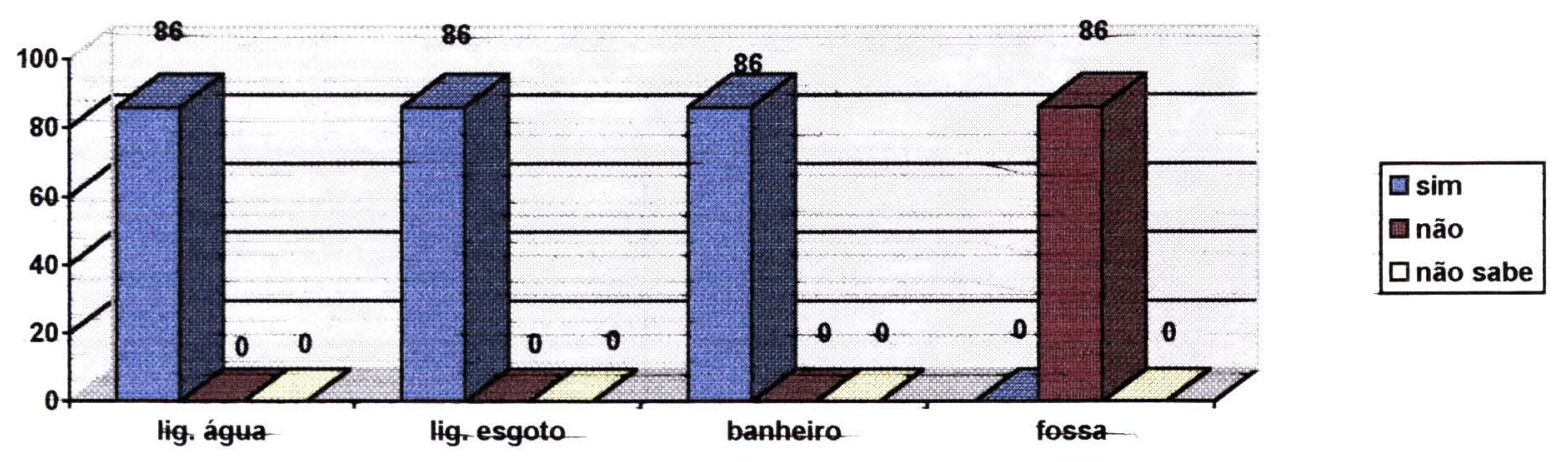

IV. Avaliação em relação às questões ligadas às empresas de saneamento e ao tratamento de esgotos

Parâmetro analisado: Conhecimento (ou não) do órgão responsável pelos serviços

\begin{tabular}{|l|c|c|c|c|c|}
\hline \multirow{2}{*}{\multicolumn{1}{|c|}{ Bairro }} & \multicolumn{5}{|c|}{ Quem executa os serviços de água e esgoto na cidade é: } \\
\cline { 2 - 6 } & o SEMAE & O DAE & a SABESP & nãa-sabe & outros \\
\hline Jardim Brasília & 38 & 00 & 00 & 10 & 01 \\
\hline Vila Independência & 30 & 00 & 00 & 07 & 00 \\
\hline Totalização & 68 & 00 & 00 & 17 & 01 \\
\hline
\end{tabular}

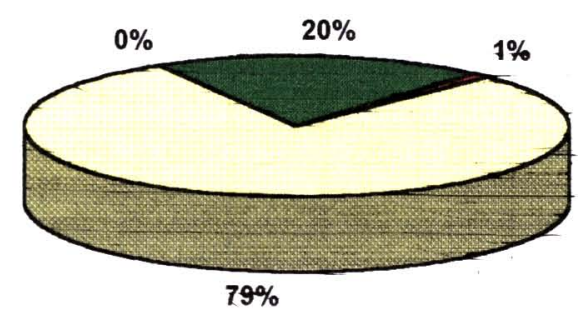

\begin{tabular}{|l|}
\hline O SEMAE \\
O DAE \\
a SABESP \\
G não-sabe \\
—outros \\
\hline
\end{tabular}


Parâmetro analisado: Serviços gerais prestados pela empresa de saneamento -

\section{Planilha 1}

\begin{tabular}{|l|c|c|c|c|c|c|c|c|c|c|}
\hline \multirow{3}{*}{ Bairro } & \multicolumn{6}{|c|}{$\begin{array}{c}\text { Classificação dos serviços gerais prestados pela empresa de saneamento } \\
\end{array}$} & \multicolumn{5}{|c|}{ atendimento ao telefone } & \multicolumn{3}{c|}{ reparos nas ligações domiciliares } \\
\cline { 2 - 11 } & $\mathrm{N}$ & $\mathrm{R}$ & $\mathrm{A}$ & $\mathrm{B}$ & $\mathrm{S}$ & $\mathrm{N}$ & $\mathrm{R}$ & $\mathrm{A}$ & $\mathrm{B}$ & $\mathrm{S}$ \\
\hline Jardim Brasília & 00 & 02 & 01 & 20 & 26 & 00 & 00 & 00 & 01 & 48 \\
\hline Vita Independência & 00 & 01 & 00 & 11 & 25 & 00 & 02 & 00 & 03 & 32 \\
\hline Totalização & 00 & 03 & 01 & 31 & 41 & 00 & 02 & 00 & 04 & 80 \\
\hline
\end{tabular}

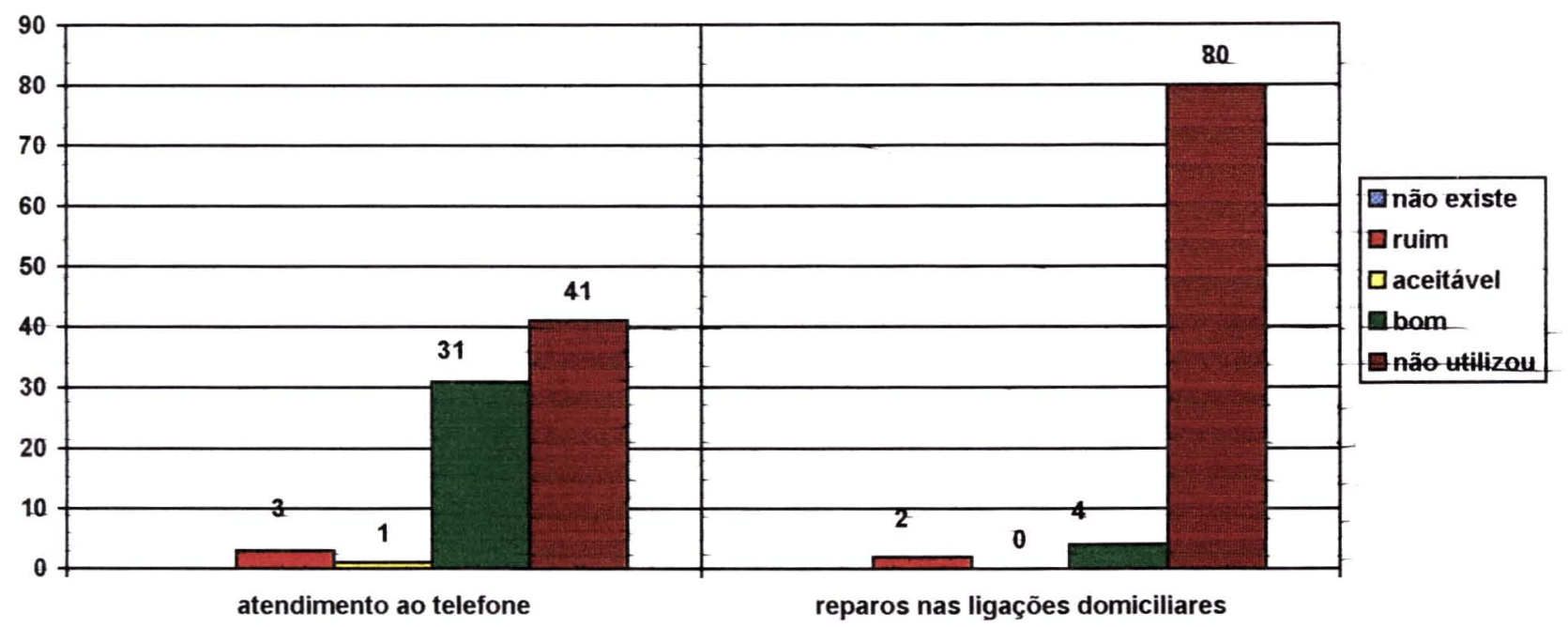

Parâmetro analisado: Serviços gerais prestados pela empresa de saneamento -

\section{Planilha 2}

\begin{tabular}{|c|c|c|c|c|c|c|c|c|c|c|c|c|c|c|c|}
\hline \multirow{3}{*}{ Bairro } & \multicolumn{15}{|c|}{$\begin{array}{l}\text { Classificação dos serviços gerais prestađos pela empresa de saneamento } \\
N=\text { não existe; } R=\text { ruim; } A=\text { aceitável; } B=\text { bom; } S \text { = ainda não precisou utilizar tal serviço }\end{array}$} \\
\hline & \multicolumn{5}{|c|}{ manut. da rede de esgoto } & \multicolumn{5}{|c|}{ manut. na rede de água } & \multicolumn{5}{|c|}{ conserto de hidrômetros } \\
\hline & $\mathrm{N}$ & $R$ & A & B & $S$ & $\mathrm{~N}$ & $R$ & $A$ & B & $S$ & $\mathrm{~N}$ & $\mathrm{R}$ & A & $B$ & $S$ \\
\hline Jardim Brasília & 00 & 00 & 01 & 11 & 37 & 00 & 00 & 00 & 00 & 49 & 00 & 01 & 00 & 05 & 43 \\
\hline Vila Independência & 00 & 00 & 00 & 00 & 37 & 00 & 00 & 00 & 02 & 35 & 00 & 01 & 00 & 08 & 28 \\
\hline Totalização & 00 & 00 & 01 & 11 & 74 & 00 & 00 & 00 & 02 & 84 & 00 & 02 & $\theta 0$ & 13 & 71 \\
\hline
\end{tabular}


Parâmetro analisado: Opinião sobre a disposição final de esgotos sanitários

\begin{tabular}{|l|c|c|c|c|c|}
\hline \multirow{2}{*}{ Baifro } & \multicolumn{5}{|c|}{ O esgoto deve ser: } \\
\cline { 2 - 6 } & $\begin{array}{c}\text { apenas } \\
\text { lançado em } \\
\text { fossas }\end{array}$ & $\begin{array}{c}\text { apenas lançado em } \\
\text { rios ou outros corpos } \\
\text { d'água }\end{array}$ & $\begin{array}{c}\text { deve ser tratado antes } \\
\text { de sua disposição na } \\
\text { terra ou no solo }\end{array}$ & outras & $\begin{array}{c}\text { não sabe } \\
\text { responder }\end{array}$ \\
\hline Jardim Brasília & 00 & 00 & 45 & 02 & 02 \\
\hline Vita Independência & 01 & 00 & 30 & 00 & 06 \\
\hline Totatização & 01 & 00 & 75 & 02 & 08 \\
\hline
\end{tabular}

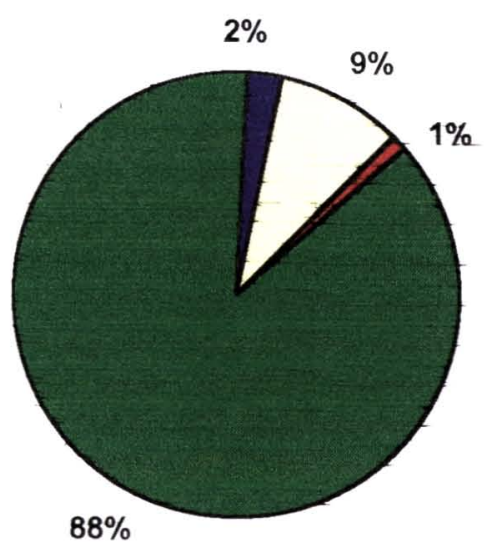

$\square$ apenas lançado em fossas

Gapenas Iançado em rios

日 deve ser tratado antes de sua disposição final

autras

$\square$ não sabe responder

Parâmetro analisado: Percepção do destino dos esgotos produzidos nas residências

\begin{tabular}{|l|c|c|c|c|c|}
\hline \multirow{2}{*}{ Baifro } & \multicolumn{4}{|c|}{ Para onde está indo o esgoto produzido em sua residência: } \\
\cline { 2 - 6 } & $\begin{array}{c}\text { direto para o rio } \\
\text { s/ tratamento }\end{array}$ & para uma fossa & para a ETE & \multicolumn{2}{c|}{$\begin{array}{c}\text { outras } \\
\text { respostas }\end{array}$} \\
\hline Jardim Brasília & 02 & 00 & 19 & 02 & 26 \\
\hline Vila Independência & 01 & 00 & 21 & 00 & 15 \\
\hline Totalização & 03 & 00 & 40 & 02 & 41 \\
\hline
\end{tabular}

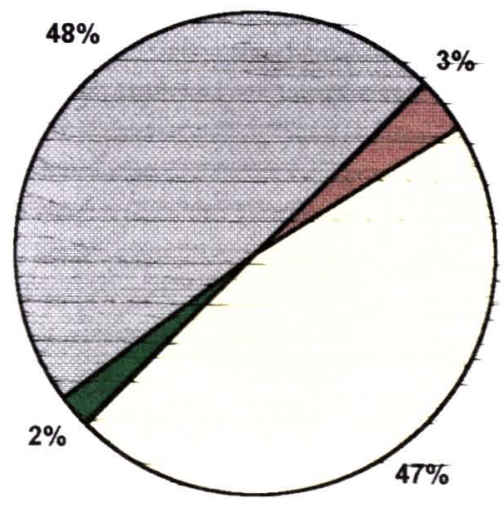
$\square$ para uma fossa
Ipara a ETE
Doutras respostas
ㅁão sabe

Ddireto para o rio s/ tratamento 
Parâmetro analisado: Percepção de impactos relacionados à ETE - Planilha 1

\begin{tabular}{|c|c|c|c|c|c|c|c|c|c|c|}
\hline \multirow{3}{*}{ Bairro } & \multicolumn{10}{|c|}{ A operação da ETE ocasionou ou está ocasionando as seguintes consequências } \\
\hline & \multicolumn{2}{|c|}{ Aumento tarifas } & \multicolumn{2}{|c|}{$\begin{array}{c}\text { Proliferação de } \\
\text { insetos }\end{array}$} & \multicolumn{2}{|c|}{$\begin{array}{l}\text { Melhoria qualid. } \\
\text { da água do rio }\end{array}$} & \multicolumn{2}{|c|}{$\begin{array}{c}\text { Cheiro } \\
\text { desagradável }\end{array}$} & \multicolumn{2}{|c|}{$\begin{array}{c}\text { Diminuição de } \\
\text { doenças }\end{array}$} \\
\hline & $\mathrm{s}$ & $\mathrm{N}$ & $\mathrm{S}$ & $\mathrm{N}$ & $S$ & $\mathrm{~N}$ & s & $\mathrm{N}$ & $s$ & $\mathrm{~N}$ \\
\hline Jardim Brasília & 02 & 47 & 23 & 26 & 20 & 29 & 46 & 03 & 00 & 49 \\
\hline Vila Independ. & 00 & 37 & 16 & 21 & 12 & 25 & 33 & 04 & 00 & 37 \\
\hline Totalização & 02 & 84 & 39 & 47 & 32 & 54 & 81 & 05 & 00 & 86 \\
\hline
\end{tabular}

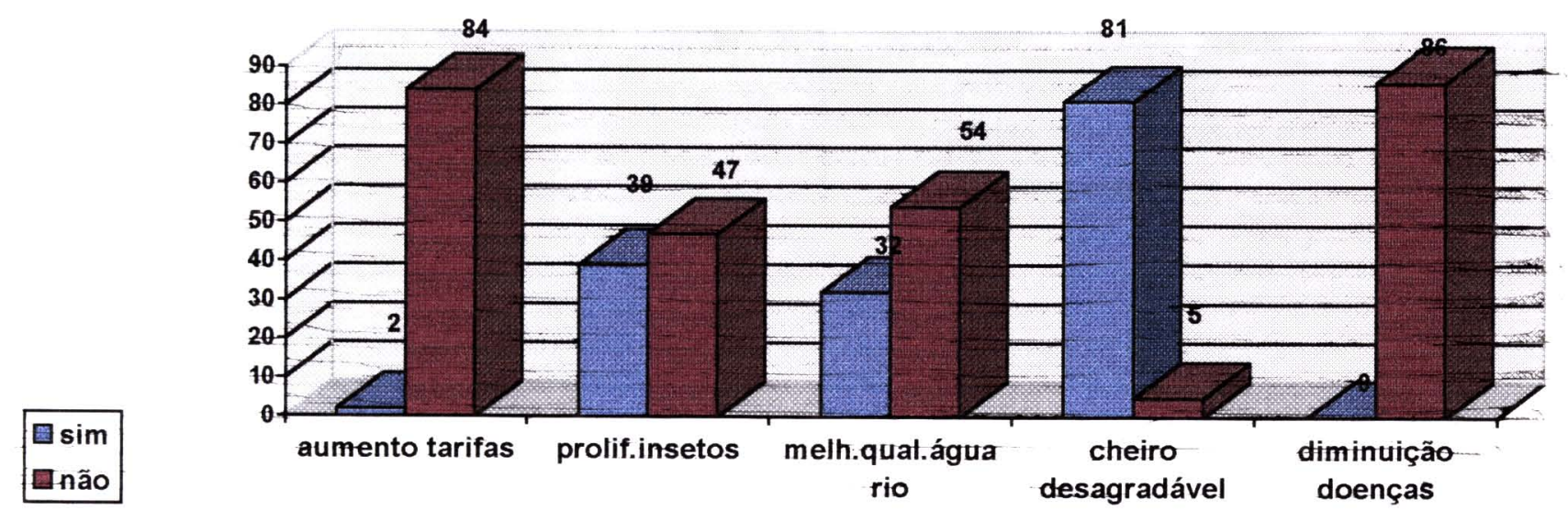

Parâmetro analisado: Percep̧̧ão de impactos relacionados à ETE - Planilha 2

\begin{tabular}{|c|c|c|c|c|c|c|c|c|c|c|}
\hline \multirow{3}{*}{ Bairro } & \multicolumn{10}{|c|}{ A operação da ETE ocasionou ou está ocasionando as seguintes consequências } \\
\hline & \multicolumn{2}{|c|}{$\begin{array}{l}\text { Produção de } \\
\text { peixes }\end{array}$} & \multicolumn{2}{|c|}{$\begin{array}{c}\text { Melhoria do lazer } \\
\text { na região }\end{array}$} & \multicolumn{2}{|c|}{ Nada } & \multicolumn{2}{|c|}{$\begin{array}{c}\text { Não sabe de } \\
\text { ETE }\end{array}$} & \multicolumn{2}{|c|}{ Outras respostas } \\
\hline & S & $\mathrm{N}$ & S & $\mathrm{N}$ & $S$ & $\mathrm{~N}$ & $S$ & $\mathrm{~N}$ & $S$ & $\mathrm{~N}$ \\
\hline Jardim Brasília & 00 & 49 & 00 & 49 & 01 & 48 & 00 & 49 & 01 & 48 \\
\hline Vila Indep. & 01 & 37 & 00 & 37 & 04 & 33 & 00 & 37 & 01 & 36 \\
\hline Totaliz. & 01 & 85 & 00 & 86 & 05 & 81 & 00 & 86 & 02 & 84 \\
\hline
\end{tabular}

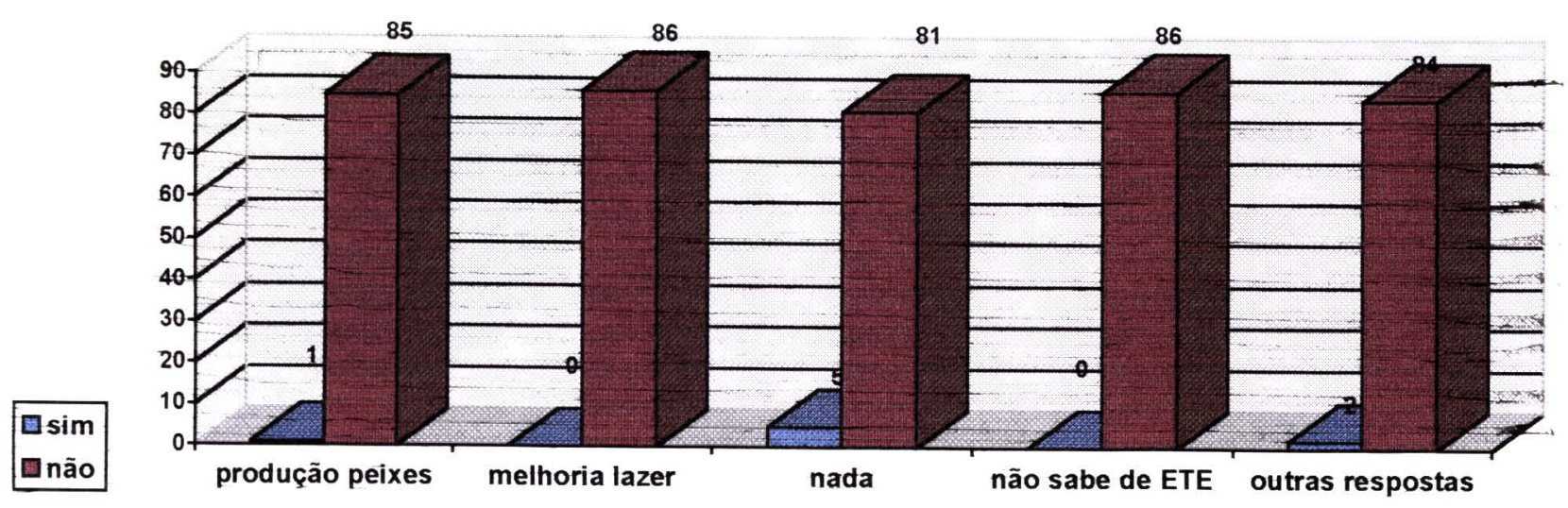


Distribuição dos impactos relacionados à ETE segundo a percepção da população

\section{vizinha}

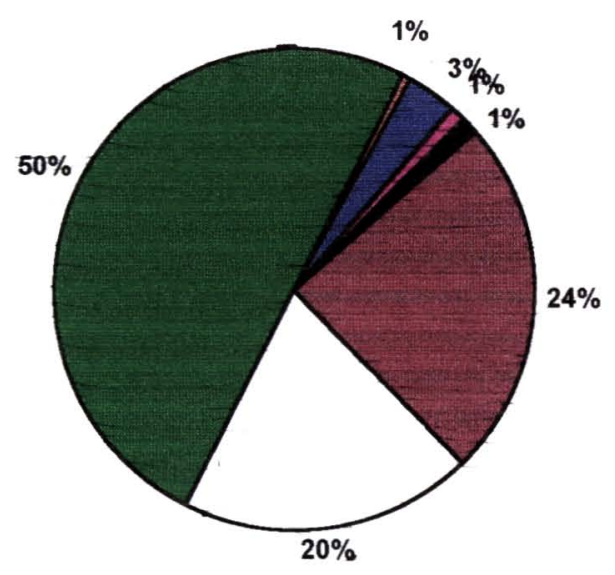

\begin{tabular}{|l|}
\hline aumento tarifas \\
$\square$ proliferação insetos \\
$\square$ melhoria qualidade água do rio \\
$\square$ cheiro desagradável \\
$\square$ diminuição de doenças \\
$\square$ produção de peixes \\
$\square$ melhoria lazer da região \\
$\square$ nenhum impacto \\
$\square$ não sabe de nenhuma ETE \\
$\square$ outras respostas
\end{tabular}

Parâmetro analisado: Percepção de medidas de controle ou redução de impactos negativos

\begin{tabular}{|l|c|c|c|}
\hline \multirow{2}{*}{ Bairro } & \multicolumn{2}{|c|}{$\begin{array}{r}\text { A empresa responsável pela ETE tomou providências para controlar ou diminuir os } \\
\text { distúrbios (efeitos negativos) sofridos pela vizinhança: }\end{array}$} \\
\cline { 2 - 4 } & SIM & NÃO & NÃO SABE \\
\hline Jardim Brasília & 26 & 10 & 13 \\
\hline Vila Independência & 14 & 01 & 22 \\
\hline Totalização & 40 & 11 & 35 \\
\hline
\end{tabular}

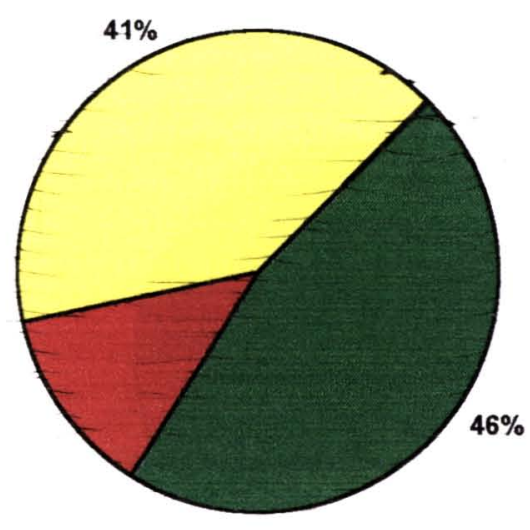

घsim
Gnão
पnão sabe


Parâmetro analisado: Ocupação anterior à ETE segundo a memória da população

\begin{tabular}{|l|c|c|c|c|c|c|}
\hline \multirow{2}{*}{ Bairro } & \multicolumn{6}{|c|}{ Como estava ocupada a área antes da implantação da ETE? } \\
\cline { 2 - 7 } & $\begin{array}{c}\text { Não se } \\
\text { lembra }\end{array}$ & $\begin{array}{c}\text { Ainda não } \\
\text { morava nas } \\
\text { proximidades }\end{array}$ & $\begin{array}{c}\text { Apenas um } \\
\text { lote vago }\end{array}$ & Área verde & Entulho & $\begin{array}{c}\text { Outras } \\
\text { respostas }\end{array}$ \\
\hline Jardim Brasília & 08 & 00 & 36 & 03 & 00 & 02 \\
\hline Vila Independência & 12 & 00 & 22 & 02 & 00 & 01 \\
\hline Totalização & 20 & 00 & 58 & 05 & 00 & 03 \\
\hline
\end{tabular}

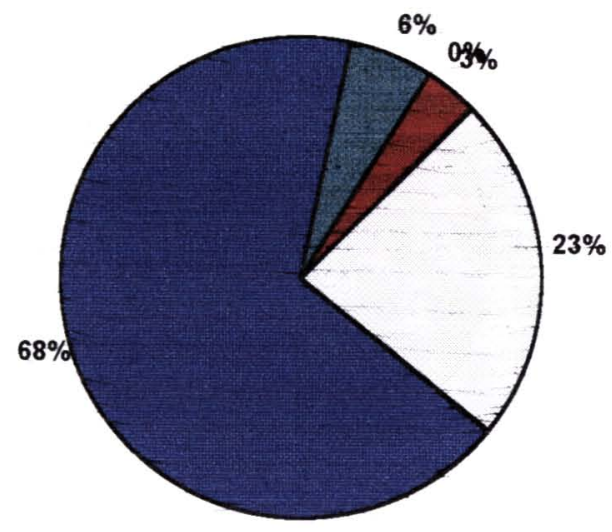

पnão se lembra

Eainda não morava nas proximidades

回apenas um lote vago

圆área verde

口entulho

日outras respostas

\section{Nivel de interferência dos odores de ETEs na vida pessoal e social da vizinha}

\section{Parâmetro analisado: Percepção de odores em relação aos meses do ano}

\begin{tabular}{|c|c|c|c|c|c|}
\hline \multirow[b]{2}{*}{ Bairro } & \multicolumn{5}{|c|}{ Os odores relacionados à ETE estão presentes: } \\
\hline & O ano todo & Ocasionalmente & $\begin{array}{c}\text { Apenas nos } \\
\text { meses quentes }\end{array}$ & $\begin{array}{l}\text { Apenas nos } \\
\text { meses frios }\end{array}$ & Nunca \\
\hline Jardim Brasília & 19 & 15 & 13 & 00 & 02 \\
\hline Vila Independência & 15 & 05 & 14 & 00 & 03 \\
\hline Totalização & 34 & 20 & 27 & 00 & 05 \\
\hline
\end{tabular}

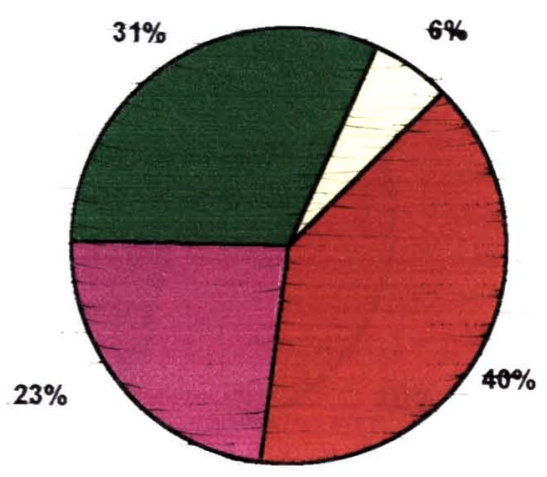
Bo ano todo
Gocasionalmente
$\square$ apenas nos meses quentes
Dapenas nos meses frios
口nunca 
Parâmetro analisado: Percepção de odores de acordo com os períodos do dia

\begin{tabular}{|l|c|c|c|c|c|c|}
\hline \multirow{2}{*}{ Bairro } & \multicolumn{6}{|c|}{ Quando são sentidos os odores } \\
\cline { 2 - 6 } & $\begin{array}{c}\text { Durante todo } \\
\text { o dia }\end{array}$ & \multicolumn{3}{|c|}{$\begin{array}{c}\text { Em periodos específicos } \\
\text { do dia }\end{array}$} & $\begin{array}{c}\text { Em periodos diferenciados de } \\
\text { acordo com as estações do ano }\end{array}$ & Nunca \\
\cline { 2 - 5 } & 08 & 02 & 15 & 22 & 00 & 02 \\
\hline Jardim Brasília & 01 & 02 & 17 & 08 & 06 & 03 \\
\hline Vila Independência & 09 & 04 & 32 & 30 & 06 & 05 \\
\hline Totalização & & 04 & Tarde & Noite & \\
\hline
\end{tabular}

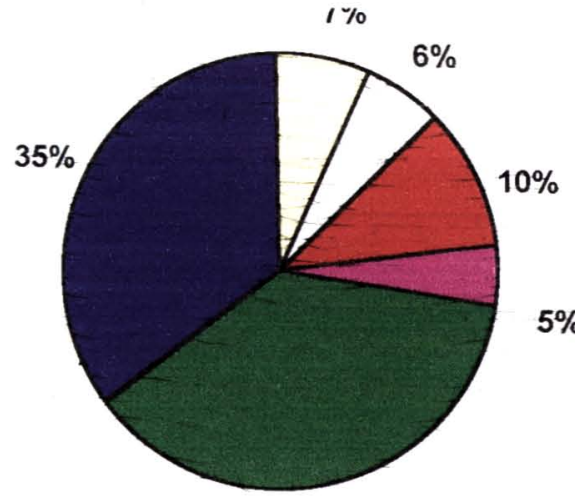

$37 \%$

\begin{tabular}{|l|}
\hline durante todo o dia \\
$\square$ manhã \\
tarde \\
noite \\
$\square$ em períodos diferenciados de acordo com as estações do: \\
ano \\
nunca
\end{tabular}

\section{Parâmetro analisado: Percepção de fatores agravantes de poluição externos à ETE}

\begin{tabular}{|c|c|c|c|c|}
\hline \multirow[b]{2}{*}{ Bairro } & \multicolumn{4}{|c|}{ O problema dos maus odores da ETE: } \\
\hline & $\begin{array}{l}\text { É agravado pela } \\
\text { presença de outras } \\
\text { fontes de poluição }\end{array}$ & $\begin{array}{l}\text { Não sofre } \\
\text { interferência } \\
\text { externa }\end{array}$ & $\begin{array}{c}\text { Não sabe afirmar } \\
\text { com certeza }\end{array}$ & $\begin{array}{c}\text { Não se queixa de } \\
\text { maus odores }\end{array}$ \\
\hline Jardim Brasília & 01 & 34 & 12 & 02 \\
\hline Vila Independência & 00 & 00 & 34 & 03 \\
\hline Totalização & 01 & 34 & 46 & 05 \\
\hline
\end{tabular}

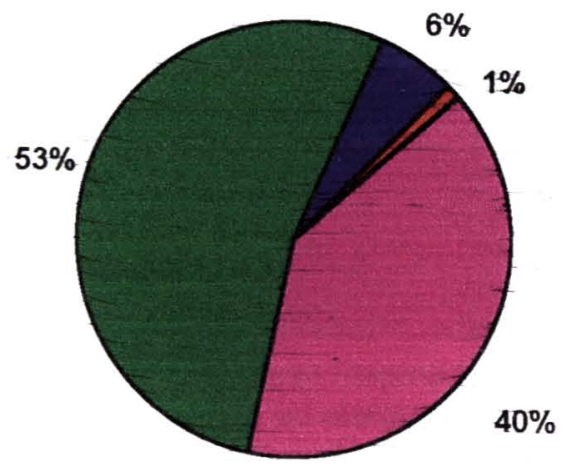

घé agravado por outras fontes de poluição

$\square$ ฉão sofre interferência externa

D não sabe afirmar com certeza

não se queixa de maus odores 
Parâmetro analisado: Incômodos relacionados à exposição aos maus odores

\begin{tabular}{|c|c|c|c|c|c|c|c|c|c|c|c|c|}
\hline \multirow{3}{*}{ Bairro } & \multicolumn{12}{|c|}{ A presença dos maus odores da ETE ocasiona ou já ocasionou } \\
\hline & \multicolumn{2}{|c|}{$\begin{array}{l}\text { Restrições na } \\
\text { utilização de } \\
\text { jardins, } \\
\text { quintais, etc. }\end{array}$} & \multicolumn{2}{|c|}{$\begin{array}{l}\text { Fechamento } \\
\text { de janelas, } \\
\text { portas, etc. }\end{array}$} & \multicolumn{2}{|c|}{$\begin{array}{c}\text { Necessidade } \\
\text { de aquisição } \\
\text { de } \\
\text { ventiladores }\end{array}$} & \multicolumn{2}{|c|}{$\begin{array}{c}\text { Doenças } \\
\text { respiratórias } \\
\text { ou alergias }\end{array}$} & \multicolumn{2}{|c|}{$\begin{array}{c}\text { Sensação de } \\
\text { mau estar }\end{array}$} & \multicolumn{2}{|c|}{$\begin{array}{c}\text { Outros } \\
\text { incômodos }\end{array}$} \\
\hline & $\mathrm{s}$ & $\mathrm{N}$ & $\mathrm{s}$ & $\mathrm{N}$ & $\mathrm{s}$ & $\mathrm{N}$ & $\mathrm{s}$ & $\mathrm{N}$ & $\mathrm{s}$ & $\mathrm{N}$ & $\mathrm{s}$ & $\mathrm{N}$ \\
\hline Jardim Brasília & 20 & 29 & 27 & 22 & 03 & 46 & 10 & 39 & 19 & 30 & 34 & 15 \\
\hline Vila Independ. & 15 & 22 & 17 & 20 & 00 & 37 & 03 & 34 & 01 & 36 & 06 & 31 \\
\hline Totaliz. & 35 & 51 & $\overline{44}$ & $\overline{42}$ & 03 & 83 & 13 & 73 & 20 & 66 & 40 & 46 \\
\hline
\end{tabular}
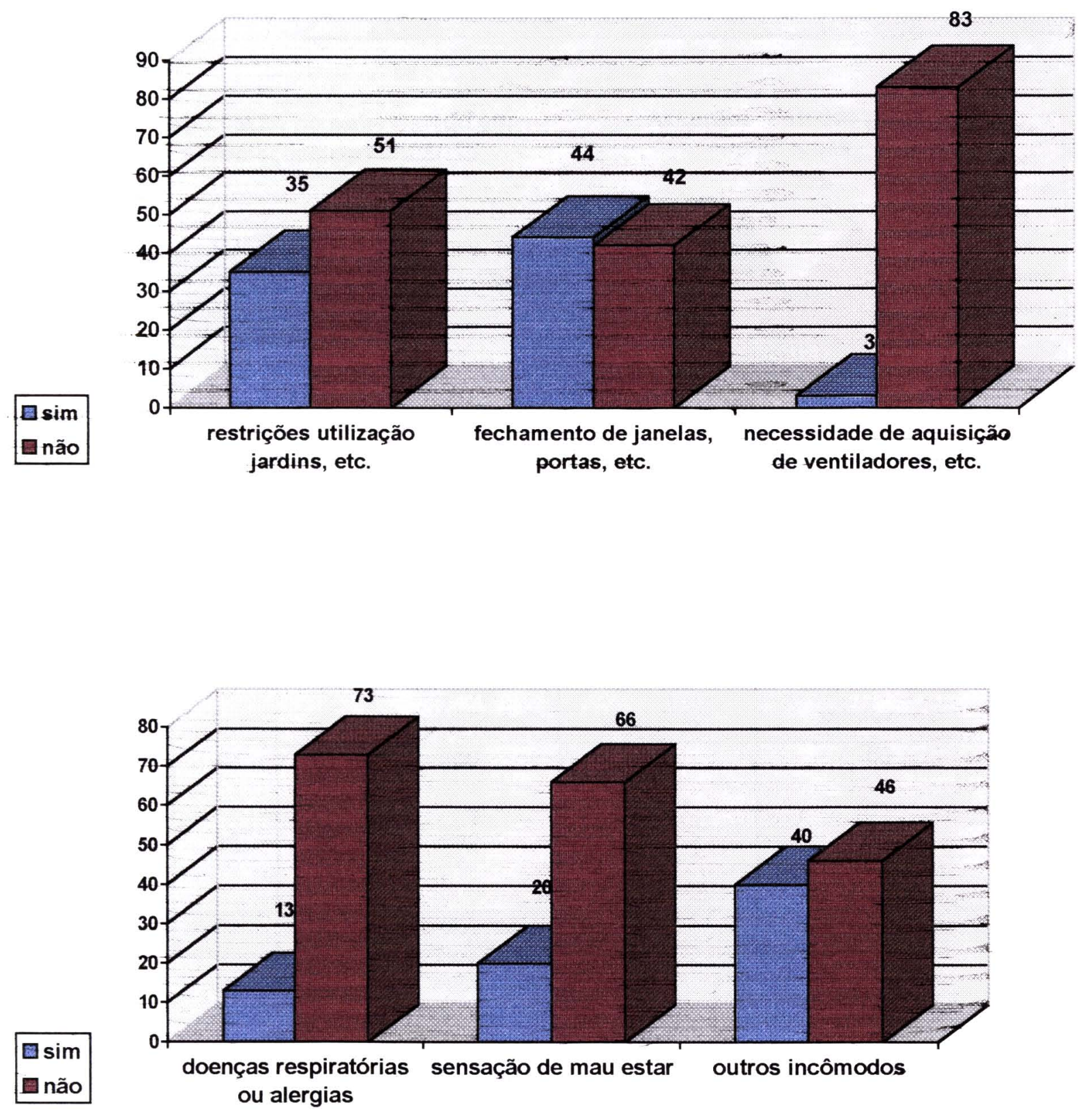


\section{Estrutura política-cultural}

Parâmetro analisado: Participação do entrevistado em associações comunitárias; assuntos tratados pelas mesmas.

\begin{tabular}{|l|c|c|c|c|c|c|c|c|c|c|c|}
\hline \multirow{2}{*}{ Bairro } & \multicolumn{2}{|c|}{$\begin{array}{c}\text { Participação em } \\
\text { associações }\end{array}$} & \multicolumn{8}{|c|}{ Assuntos tratados pelas } \\
\cline { 2 - 12 } & Não & Sim & $\begin{array}{c}\text { mora- } \\
\text { dia }\end{array}$ & $\begin{array}{c}\text { infra- } \\
\text { estr. }\end{array}$ & $\begin{array}{c}\text { man. } \\
\text { rua }\end{array}$ & $\begin{array}{c}\text { políti- } \\
\text { ca }\end{array}$ & $\begin{array}{c}\text { religi- } \\
\text { ão }\end{array}$ & $\begin{array}{c}\text { meio } \\
\text { amb. }\end{array}$ & $\begin{array}{c}\text { espor- } \\
\text { te }\end{array}$ & $\begin{array}{c}\text { artes } \\
\text { outros }\end{array}$ \\
\hline $\begin{array}{l}\text { Jardim } \\
\text { Brasília }\end{array}$ & 42 & 07 & 00 & 05 & 00 & 00 & 01 & 03 & 02 & 00 & 02 \\
\hline $\begin{array}{l}\text { Vila } \\
\text { Independência }\end{array}$ & 32 & 05 & 00 & 02 & 00 & 00 & 02 & 01 & 00 & 00 & 02 \\
\hline Totalização & 74 & 12 & 00 & 07 & 00 & 00 & 03 & 04 & 02 & 00 & 04 \\
\hline
\end{tabular}

Participação do entrevistado em associações comunitárias

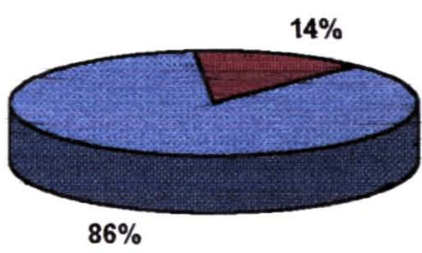

Assuntos tratados pelas instituições

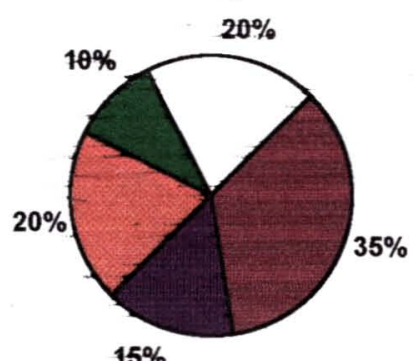

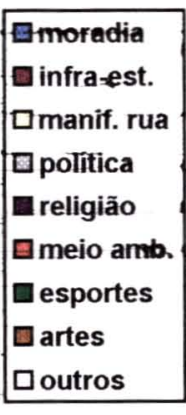

口outros

Parâmetro analisado: Participação do entrevistado em associações comunitárias; resultados obtidos.

\begin{tabular}{|c|c|c|c|c|c|c|}
\hline \multirow[b]{2}{*}{ Bairro } & \multicolumn{2}{|c|}{$\begin{array}{l}\text { Participação em } \\
\text { associações }\end{array}$} & \multicolumn{4}{|c|}{$\begin{array}{l}\text { Avaliação do entrevistado cl relação aos resultados obtidos quando da } \\
\text { apresentação de reivindicações públicas pelas associações }\end{array}$} \\
\hline & Não & Sim & $\begin{array}{l}\text { as assoc. não } \\
\text { apresentam } \\
\text { reivindicações }\end{array}$ & $\begin{array}{c}\text { os resultados não } \\
\text { têm sido } \\
\text { satisfatórios }\end{array}$ & $\begin{array}{l}\text { os resultados têm } \\
\text { sido relativamente } \\
\text { satisfatórios }\end{array}$ & $\begin{array}{l}\text { os resultados } \\
\text { têm sido } \\
\text { satisfatórios }\end{array}$ \\
\hline $\begin{array}{l}\text { Jardim } \\
\text { Brasilia }\end{array}$ & 42 & 07 & 00 & 07 & 00 & 00 \\
\hline $\begin{array}{l}\text { Vila } \\
\text { Independência }\end{array}$ & 32 & 05 & 02 & 01 & 02 & 00 \\
\hline Totalização & 74 & 12 & 02 & 08 & 02 & 00 \\
\hline
\end{tabular}

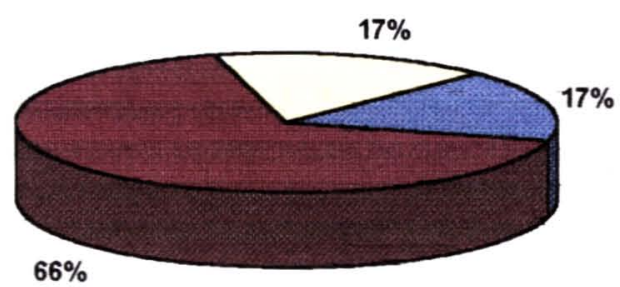

G as assoc. não apresentam reivindicações

Eos resultados não têm sido satisfatórios

Dos resultados têm sido relativamente satisfatórios

Eos resultados têm sido satisfatórios 
Parâmetro analisado: Perfil político do entrevistado

\begin{tabular}{|l|c|c|c|c|c|c|}
\hline \multirow{3}{*}{ Bairro } & \multicolumn{7}{|c|}{ Perfil político do entrevistado } \\
\cline { 2 - 7 } & $\begin{array}{c}\text { o entrevist. } \\
\text { discute } \\
\text { política }\end{array}$ & $\begin{array}{c}\text { o entrevistado } \\
\text { discute politica } \\
\text { com a } \\
\text { familia }\end{array}$ & $\begin{array}{c}\text { o entrevistado } \\
\text { discute política } \\
\text { com os } \\
\text { vizinhos }\end{array}$ & $\begin{array}{c}\text { o entrevistado } \\
\text { discute política } \\
\text { com os } \\
\text { amigos }\end{array}$ & $\begin{array}{c}\text { o entrevistado } \\
\text { discute política } \\
\text { no } \\
\text { trabalho }\end{array}$ \\
\hline Jardim Brasítia & 23 & 26 & 20 & 08 & 17 & 02 \\
\hline Vila Independ. & 14 & 23 & 08 & 05 & 13 & 02 \\
\hline Totalização & 37 & 49 & 28 & 13 & 30 & 04 \\
\hline
\end{tabular}

O entrevistado discute política?

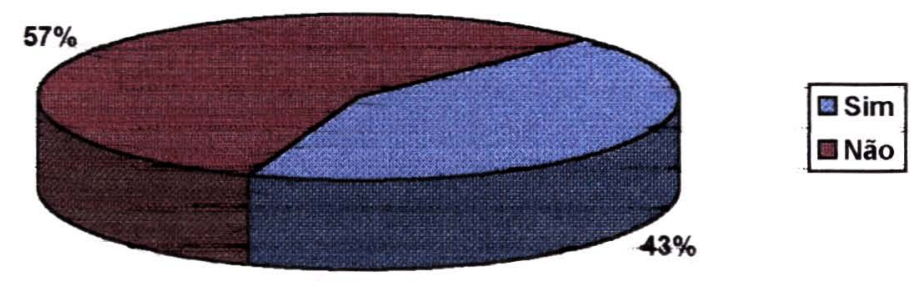

Dos que discutem, com quem discutem:

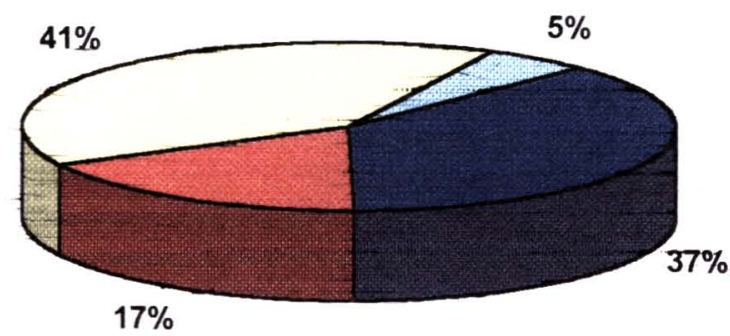

\begin{tabular}{|l|}
\hline familia \\
$\square$ vizinhos \\
$\square$ amigos \\
$\square$ no trabalho
\end{tabular}

$17 \%$ 


\section{Parâmetro analisado: Classe social}

\begin{tabular}{l|c|c|c|c|c|c|}
\hline \multirow{2}{*}{ Bairro } & \multicolumn{6}{|c|}{ Classificação que o entrevistado confere a si próprio com relação à classe social a que } \\
& \multicolumn{7}{|c|}{ pertence: } \\
\cline { 2 - 7 } & rica ou abastada & média alta & média & média baixa & pobre & outra \\
\hline Jardim Brasília & 00 & 02 & 27 & 17 & 03 & 00 \\
\hline Vila Independ. & 00 & 00 & 18 & 14 & 05 & 00 \\
\hline Totalização & 00 & 02 & 45 & 31 & 08 & 00 \\
\hline
\end{tabular}

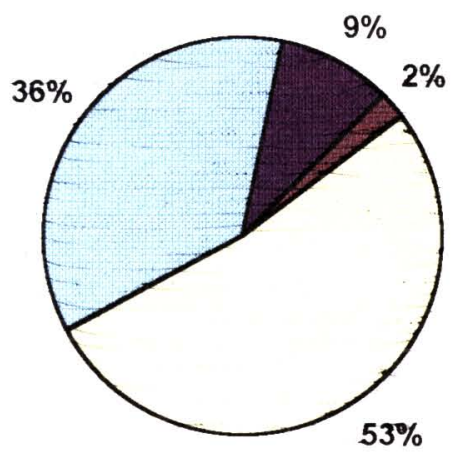

\begin{tabular}{|l|}
\hline rica \\
$\square$ média alta \\
$\square$ média \\
$\square$ média baixa \\
$\square$ pobre \\
$\square$ outra
\end{tabular}

$53 \%$ 
ANEXO 4

"Fotos emapas" 


\section{AVALIAÇÃO DO IMPACTO DA PROLIFERAÇÃO DE ODORES OFENSIVOS DO TRATAMENTO DE ESGOTOS SOBRE A \\ SAÚDE E O BEM ESTAR PÚBLICOS: \\ ETE - PIRACICAMIRIM - PIRACICABA - SP}

\section{- REVISÃO DE TESE - ERRATA -}

\section{Capítulo 1}

$\mathrm{Na}$ pág. 2 , parágrafo $1^{\circ}$, trocou-se a palavra "avaliação" por "estudo", ficando assim definido o objetivo do trabalho apresentado:

O objetivo deste trabalho consiste no estudo do impacto da proliferação de odores ofensivos decorrentes da operação da ETE Piracicamirim, em Piracicaba - SP, por meio da análise da percepção da população vizinha à estação.

$\mathrm{Na}$ apresentação da hipótese, também foram feitas modificações, a saber, na pág. 3 , parágrafo $2^{\circ}$, retirou-se a expressão "saúde" e acrescentouse "qualidade de vida":

A proliferação de odores ofensivos decorrente da operação da ETE Piracicamirim, em Piracicaba - SP, repercute negativamente sobre o bem estar e a qualidade de vida da população vizinha, compreendida pelo raio de $1 \mathrm{~km}$ ao redor da estação 


\section{Capitulo 3}

Na FIGURA 3.1, apresentada na pág. 20, a seta demonstrativa do elemento areia, deve estar posicionada sobre a superfície em amarelo.

Na pág. 27, ao final do penúltimo parágrafo, deve vir a citação da fonte* para as técnicas apontadas para o tratamento de gases odorantes:

Existem várias técnicas para tratamento de gases odorantes, tais como métodos físicos e químicos como oxidação térmica, lavadores químicos, ozonização e adsorção por carvão ativado e métodos biológicos como biofiltração, biolavadores e lodos ativados (ANDRADE et al., 2001).

*ANDRADE, T., et alli. "Uso Simultâneo de um Biofiltro Aerado Submerso para Tratamento Secundário de Esgoto Sanitário e para Biodesodorização de $\mathrm{Ar}$ Atmosférico Contendo Gás Sulfídrico $\left(\mathrm{H}_{2} \mathrm{~S}\right)$ " In: Pós-Tratamento de Efluentes de Reatores Anaeróbios - Coletânea de Trabalhos Técnicos - Volume 2. Programa de Pesquisas em Saneamento Básico (PROSAB). Belo Horizonte, p. 141-152.

\section{Capítulo 5}

Os QUADROS 5.1, 5.2 e 5.3 (págs. 40, 41 e 42, respectivamente), por apresentarem dados numéricos que são trabalhados matematicamente ao longo de suas colunas, devem receber a nomenclatura de tabelas, no caso TABELAS 5.1, 5.2 e 5.3, não podendo, desta forma, apresentar fechamento lateral (vide exemplo da TABELA 7.1 - pág. 91).

\section{Capítulo 7}

Como proposto anteriormente nesta revisão, também na pág. 79 , parágrafo $1^{\circ}$, onde se trata do objetivo do trabalho, foi substituída a palavra "avaliação" por "estudo": 
O objetivo deste trabalho, como salientado no capitulo 1, constituiu-se no estudo do impacto da proliferação de odores ofensivos decorrentes da operação da ETE - Piracicamirim, em Piracicaba - SP, por meio da análise da percepção da população vizinha, situada na área compreendida pelo raio de $1 \mathrm{Km}$, a partir da estação.

No parágrafo $2^{\circ}$, em função da alteração proposta para a hipótese e apresentada nesta revisão para o capítulo 1 , também aqui é suprimida a expressão "saúde" e acrescentada "qualidade de vida":

A hipótese a ser verificada, foi de que a proliferação de odores ofensivos decorrente da operação da ETE - Piracicamirim, em Piracicaba $S P$, repercutia negativamente sobre o bem estar e a qualidade de vida da população vizinha.

Ainda na pág. 79 , o parágrafo $4^{\circ}$, que prossegue discorrendo acerca da metodologia do trabalho científico, apresentou alterações importantes, sendo refeito da seguinte forma:

Apesar de tratar-se de um estudo quantitativo, que utiliza um questionário de perguntas fechadas para analisar um problema especifico, este trabalho apresenta também um enfoque qualitativo, ao abordar aspectos relacionados à percepção da população estudada.

\section{Capítulo 8}

A partir da pág. 96 e por todo o texto do capítulo 8 , alterou-se a expressão "mau estar" grafada incorretamente por sua forma correta que é "mal estar".

Na pág. 105, em relação à faixa etária "idosos", foi acrescentado um asterisco e apresentada a seguinte ressalva: 
- Idosos - individuos de 56 anos e acima*.

* Apenas para fins de apresentação de dados nesta pesquisa, foram considerados como idosos individuos acima dos 56 anos, pois fatores tais como o aumento da expectativa de vida e a permanência no mercado de trabalho até os 65 anos ou mais, têm merecido a revisão do conceito de idoso, ou de indivíduo na $3^{a}$ idade.

\section{Capítulo 9}

Na pág. 148, no penúltimo parágrafo, referindo-se ao objetivo, alterouse a expressão "avaliação" por "estudo":

Ao final deste trabalho, considera-se alcançado o objetivo inicial que consistia no estudo do impacto da proliferação de odores ofensivos decorrentes da operação da ETE - Piracicamirim, em Piracicaba - SP, através da análise da percepção da população vizinha à estação.

Na pág. 149, no parágrafo $3^{\circ}$, quando se trata da hipótese, excluiu-se a palavra "saúde" e acrescentou-se "qualidade de vida":

Quanto à hipótese levantada de que a proliferação de odores ofensivos decorrente da operação da ETE - Piracicamirim, em Piracicaba $S P$, repercutia negativamente sobre o bem estar e a qualidade de vida da população vizinha, compreendida pelo raio de $1 \mathrm{~km}$ ao redor da estação, a mesma fica comprovada pelos seguintes percentuais: identificação do impacto (94\%); necessidade de fechamento de portas e janelas (51\%); restrições no uso de áreas externas às residências (41\%); mal estar (23\%); doenças respiratórias (15\%).

Ainda na pág. 149, no parágrafo $4^{\circ}$, foram feitas alteraçães, como apresenta-se a seguir:

Tem-se que o impacto da proliferação de odores reforçou seu aspecto de Saúde Pública, na medida em que é percebido como responsável pelo 
comprometimento do bem estar público, e ainda, por acarretar agravos à qualidade de vida da população exposta ao problema.

\section{Capitulo 10}

Na pág. 154 , parágrafo $4^{\circ}$, onde lê-se BUNICORE, A.J. \& DAVES, W.T. (1992), o sobrenome do segundo autor está grafado incorretamente, sendo que a forma correta é: BUNICORE, A.J. \& DAVIS, W.T. (1992). 